\title{
Institutional Change in Southeast Asia
}

Institutional Change in Southeast Asia examines the institutional changes taking place in, and challenges facing, the region since 1997. Southeast Asia's economic development over the last decades has been impressive. Most of the region achieved consistently high growth rates accompanied by significant structural transformation and industrialization, poverty alleviation and improvements in their overall standard of living as indicated by such social indicators as greater longevity, more widespread delivery of basic education and lower infant mortality rates. However, the crisis that struck Southeast Asia in 1997 had severe economic, social and political consequences. It also threw into doubt the future economic prosperity of the countries in Southeast Asia and raised intriguing questions about the quality of their institutions and their approach to economic development.

This book argues that the economies of Southeast Asia need to reform their institutions if the previous rapid development is to continue and focuses on the determinants of, and implementation of, such reform. Against the backdrop of Southeast Asia's importance in the world economy, it is hardly possible to overestimate the need to understand this process of change.

Fredrik Sjöholm is Associate Professor at the Stockholm School of Economics and works mainly in international economics and development economics.Jose Tongzon is Associate Professor at the Department of Economics, National University of Singapore, and specializes in trade and development with a focus on the economies of Southeast Asia. 
European Institute of Japanese Studies, East Asian Economics \& Business Series

Edited by Marie Söderberg

Stockholm School of Economics, Sweden

\section{THE EUROPEAN INSTITUTE OF \\ JAPANESE STUDIES}

This series presents cutting edge research on recent developments in business and economics in East Asia. National, regional and international perspectives are employed to examine this dynamic and fast-moving area.

1 The Business of Japanese Foreign Aid

Five case studies from Asia

Edited by Marie Söderberg

2 Chinese Legal Reform

The case of foreign investment law Yan Wang

3 Chinese-Japanese Relations in the Twenty First Century Complementarity and conflict

Edited by Marie Söderberg

4 Competition Law Reform in Britain and Japan

Comparative analysis of policy network

Kenji Suzuki

5 Financial Liberalization and the Economic Crisis in Asia Edited by Chung H. Lee

6 Institutional Change in Southeast Asia Edited by Fredrik Sjöholm and Jose Tongzon 


\title{
Institutional Change in Southeast Asia
}

\author{
Edited by Fredrik Sjöholm \\ and Jose Tongzon
}


First published 2005

by RoutledgeCurzon

Published 2017 by Routledge

2 Park Square, Milton Park, Abingdon, Oxon OX14 4RN

711 Third Avenue, New York, NY 10017, USA

Routledge is an imprint of the Taylor \& Francis Group, an informa business

First issued in paperback 2012

Copyright @ 2005 Fredrik Sjöholm and Jose Tongzon, editorial matter and selection; the contributors, their chapters

Typeset in Baskerville by Wearset Ltd, Boldon, Tyne and Wear

The Open Access version of this book, available at

www.tandfebooks.com, has been made available under a Creative

Commons Attribution-Non Commercial-No Derivatives 4.0 license.

British Library Cataloguing in Publication Data

A catalogue record for this book is available from the British Library

Library of Congress Cataloging in Publication Data

A catalog record for this book has been requested

ISBN 978-0-415-33871-4 (hbk) 


\section{Contents}

List of figures vii

List of tables viii

List of contributors $\quad \mathbf{x}$

Series editor's preface $\quad$ xi

Acknowledgments xii

Abbreviations xiii

$\begin{array}{ll}\text { Introduction } & 1\end{array}$

FREDRIK SJÖHOLM AND JOSE TONGZON

1 Institutional transition and transition cost:

a methodological consideration $\quad 9$

JANG-SUP SHIN

2 Educational reforms and challenges in Southeast Asia 28 FREDRIK SJÖHOLM

3 Technological governance in ASEAN - failings in technology transfer and domestic research

JON SIGURDSON AND KRYSTYNA PALONKA

4 Interest rate policy and its implication on the banking restructuring programs in Indonesia

REZA Y. SIREGAR

5 Crisis, social sector and income distribution in Singapore and Thailand 
vi Contents

6 Effects of a crisis? Institutional adjustment and pro-poor growth in Thailand

PERNILLA SJÖQUIST RAFIQUI AND ÖRJAN SJÖBERG

7 Singapore's extra-ASEAN free trade agreements and their implications for ASEAN

JOSE L. TONGZON

8 Prospects for Asian monetary cooperation:

pipedream or possible reality?

168

PETER WILSON

Index 


\section{Figures}

4.1 Nominal exchange rate of Indonesian rupiah against the US dollar, January 1997 to December 2001

$4.2 \operatorname{GARCH}(1,1)$ volatility rate of Indonesian rupiah against the US dollar, daily observations, 1 August 1997 to 12 June 2002

4.3 Interest rate spread (working capital rate and 6-month deposit rate), and the SBI-1 month rate in Indonesia, July 1997 to December 2000

4.4 Banking industry in Indonesia, profits before tax ( $\mathrm{Rp}$ trillion)

4.5 Gross non-performing loans in Indonesia, in percent of total loans

5.1 Unemployment rate (unadjusted) in Singapore, 1995-1999

5.2 Unemployment rate in Singapore, per person aged 15 years and older in resident private household, per decile, in percent 98

5.3 Real incomes by origin in Thailand, 1997-1999

5.4 Incomes at various education levels in Thailand

5.5 Changes in government real recurrent expenditure per student in Singapore, 1995-1999 (S\$)

5.6 Changes in enrollment at various educational levels in Singapore, 1996-1999

5.7 Changes in drop-out ratios in secondary schools in Thailand 108

6.1 Institutions, policies and outcomes 


\section{Tables}

1.1 Cross-border M\&As and FDI inflows in Malaysia and Korea 1991-2002 (US\$ million)

1.2 Trend of NPLs in Malaysia and Korea, 1997-2001 21

1.3 External financing of the corporate sector in Korea (billion won)

2.1 Exports, current account balances and exchange rates in some Southeast Asian countries

2.2 Educational expenditures in Southeast Asia

$\begin{array}{lll}2.3 & \text { Educational expenditures per pupil, } 1996 & 31 \\ 2.4 & \text { The availability of teachers in Southeast Asia } & 32\end{array}$

$\begin{array}{lll}2.4 & \text { The availability of teachers in Southeast Asia } & 32 \\ 2.5 & \text { Literacy rates and mean years of schooling in Southeast Asia } & 33\end{array}$

2.6 School enrollment ratios in Southeast Asia 34

2.7 Distribution of tertiary students over field of study in Southeast Asia, in percentage of students by field of study, $1996 \quad 35$

2.8 Income per capita in Southeast Asia and UNDP's education index, 1999

4.1 Banking credits outstanding in Indonesia, 1996-2001 73

4.2 GDP growth rate in Indonesia, in percent, by industrial origin at constant market prices, 1995-2001

4.3 GDP growth rate in Indonesia, in percent, by expenditure category at constant market prices, 1995-2001

4.4 Recapitalized bonds in Indonesia, at the end of 2001 (Rp trillion)

4.5 Eleven main recapitalized banks in Indonesia, bonds and total assets, at the end of 2000 (Rp trillion)

$\begin{array}{ll}\text { 4.6 Granger-causality test, rupiah and 1-month SBI rate } \\ \text { 4.7 Granger-causality test, base money (M0) and 1-month SBI rate } & 85\end{array}$

4.8 Granger-causality test, 1-month SBI rate, 6-month deposit rate and lending rate

5.1 Various indicators in Singapore and Thailand 93

5.2 Government expenditures on social and community services in Singapore and Thailand

5.3 Average household income from work in Singapore, by decile 
Tables ix

5.4 Current income share of households in Thailand, by quintile, and the Gini coefficient

5.5 Singapore government's real expenditure on education, 1995-1999

5.6 Education expenditure of Thailand, 1995-1999 (million baht) 107

5.7 Government budgets for the health sectors in Thailand and Singapore, 1995-1999

5.8 Incidence of various government programs in Thailand

6.1 Some historical socio-economic indicators for Thailand

6.2 Some socio-economic indicators for Thailand, 1996-2002 139

7.1 ASEAN6 average CEPT tariff rates, in percent, $1997 \quad 152$

7.2 ASEAN6 CEPT product list, as of 1 January 2002

7.3 ASEAN4 CEPT product list, as of 1 January 2002

7.4 Implementation of tariff reduction commitments in ASEAN, as of 1 January 2002

$\begin{array}{lll}\text { 8.1 } & \text { Basic economic indicators for East Asian countries, } 1997 & 170 \\ \text { 8.2 } & \text { Asian monetary arrangements, 1990, 1997, 2001 } & 174\end{array}$

8.3 Asian exchange rate volatility during the crisis period, June 1997 to December 1998

8.4 International reserves, 1990, 1997 and $1999 \quad 180$

8.5 Regional trade, in percent of total regional GDP, 1985 and 1998

8.6 Average intra-ASEAN5 trade flows, in percent, 1990-1996 


\section{Contributors}

Pundarik Mukhopadhaya is at the Economics Department, Macquarie University, Sydney, Australia.

Krystyna Palonka is with the East Asia Science and Technology Program at the European Institute of Japanese Studies, Stockholm School of Economics, Sweden.

Pernilla Sjöquist Rafiqui is at the Department of Economics, Stockholm School of Economics, Sweden.

Jang-Sup Shin is at the Department of Economics, National University of Singapore.

Jon Sigurdson is with the East Asia Science and Technology Program at the European Institute of Japanese Studies, Stockholm School of Economics, Sweden.

Reza Y. Siregar is at the School of Economics, Adelaide University, Australia.

Örjan Sjöberg is at the Department of Economics and the European Institute of Japanese Studies, Stockholm School of Economics, Sweden.

Fredrik Sjöholm is at the European Institute of Japanese Studies, Stockholm School of Economics, Sweden.

Jose L. Tongzon is at the Department of Economics, National University of Singapore.

Peter Wilson is at the Department of Economics, National University of Singapore. 


\section{Series editor's preface}

The Asian crisis is over, but what happened during the last years of the 1990s continues to affect the region's economic development. The crisis in 1997 raised a number of intriguing questions about the Southeast Asian countries' approach to economic development as well as the soundness and quality of their institutions. It became obvious that institutional reforms were needed if the previous rapid economic development was to continue. Specific reforms have also been undertaken and continue in the various countries, although the scope of reforms, the manner in which they were executed and their success greatly differs.

Various interest groups as well as governments themselves are frequently opposed to reforms that diminish their own influence. Although some clearly recognized the need for reforms, there were also several instances where such reforms were only initiated after turbulent political changes.

It is these institutional changes as well as the challenges facing the region that is the subject of this volume. This book fills a gap in the existing literature that is extensive in its examination of the factors behind the crisis, but lacking with regard to the institutional changes that have taken place and how they have affected the economic development in Southeast Asia.

The book focuses on determinants to the adjustments and implementation of institutional change and various differences between the countries in the region. The comparative angle gives a deeper understanding than a study of specific countries or subject areas would have done. It helps us to understand why some countries changed while others did not. Understanding this is important for anyone interested in Southeast Asia's development and the way the region is heading.

Marie Söderberg 


\section{Acknowledgments}

This volume is the result of a joint project between the European Institute of Japanese Studies (EIJS) at the Stockholm School of Economics, and the Department of Economics at the National University of Singapore (NUS). The scope of the project was to analyze the development in Southeast Asia after the financial crisis in 1997; the project involved a large number of economists, some of whom contributed with chapters to this book. Researchers from EIJS, NUS, and several other institutions participated in two conferences organized in Singapore and Stockholm, in 2001 and 2002 respectively. We are grateful to all participants for the lively discussions that helped to sharpen our focus and our arguments. Hal Hill read and provided detailed comments and suggestions on all the included chapters in an early version of the manuscript. His profound knowledge of Southeast Asia, and his generous sharing of this expertise, is gratefully acknowledged. The book has also benefited from comments by two anonymous referees. Marie Tsujita Stephenson has been of tremendous help with the manuscript, and the book would not have been in a publishable state without her excellent work. Finally, we are grateful for the financial support from EIJS and NUS.

Fredrik Sjöholm and Jose Tongzon March 2004. 


\section{Abbreviations}

\begin{tabular}{|c|c|}
\hline $\mathrm{ADB}$ & Asian Development Bank \\
\hline AFTA & ASEAN Free Trade Area \\
\hline AIC & ASEAN Industrial Complementation \\
\hline $\mathrm{AMF}$ & Asian Monetary Fund \\
\hline APEC & Asia-Pacific Economic Cooperation \\
\hline ARF & ASEAN Regional Forum \\
\hline ARIC & Asia Recovery Information Center \\
\hline ASEAN & Association of Southeast Asian Nations \\
\hline ASEAN4 & $\begin{array}{l}\text { Newer members of ASEAN - Cambodia, Laos, Myanmar } \\
\text { and Vietnam }\end{array}$ \\
\hline ASEAN5 & $\begin{array}{l}\text { Original member countries of ASEAN - Indonesia, } \\
\text { Malaysia, the Philippines, Singapore and Thailand }\end{array}$ \\
\hline ASEAN6 & $\begin{array}{l}\text { Brunei, Indonesia, Malaysia, the Philippines, Singapore } \\
\text { and Thailand }\end{array}$ \\
\hline ASEAN8 & ASEAN10, except Brunei and Cambodia \\
\hline ASEAN10 & $\begin{array}{l}\text { all member countries of ASEAN - Brunei, Cambodia, } \\
\text { Indonesia, Laos, Malaysia, Myanmar, the Philippines, Sin- } \\
\text { gapore, Thailand and Vietnam }\end{array}$ \\
\hline ASEAN +3 & $\begin{array}{l}\text { all ten member countries of ASEAN and China, Japan } \\
\text { and Korea }\end{array}$ \\
\hline ASEM & Asia-Europe Meeting \\
\hline BBC & brand-to-brand scheme \\
\hline CEPT & Common Effective Preferential Tariff \\
\hline CFA & $\begin{array}{l}\text { a French franc based currency used primarily in fran- } \\
\text { cophone African countries }\end{array}$ \\
\hline GIEM & Central Institute for Economic Management, Vietnam \\
\hline CNPS & cross-national production systems \\
\hline $\mathrm{CPF}$ & Central Provident Fund, Singapore \\
\hline CPN & cross-national production networks \\
\hline CTTC & $\begin{array}{l}\text { Comprehensive Technology Transfer and Commercializa- } \\
\text { tion, the Philippines }\end{array}$ \\
\hline DOS & Department of Statistics, Singapore \\
\hline DOST & Department of Science and Technology, the Philippines \\
\hline
\end{tabular}


xiv Abbreviations

\begin{tabular}{|c|c|}
\hline EADS & East Asian dollar standard \\
\hline $\mathrm{ECB}$ & European Central Bank \\
\hline EDB & Economic Development Board, Singapore \\
\hline EFTA & $\begin{array}{l}\text { European Free Trade Association, comprising Iceland, } \\
\text { Liechtenstein, Norway and Switzerland }\end{array}$ \\
\hline EMS & $\begin{array}{l}\text { European Monetary System; also electronic manufactur- } \\
\text { ing services }\end{array}$ \\
\hline EMU & European Monetary Union \\
\hline ERM & exchange rate mechanism \\
\hline EU & European Union \\
\hline FDI & foreign direct investment \\
\hline FLC & forward-looking criteria \\
\hline FTA & free trade agreement \\
\hline GAB & General Arrangements to Borrow \\
\hline GDP & gross domestic product \\
\hline GEL & general exclusion list \\
\hline GNP & gross national product \\
\hline GRI & government research institute \\
\hline HDB & Housing Development Board, Singapore \\
\hline HDD & hard disk drive \\
\hline IBRA & Indonesian Banking Restructuring Agency \\
\hline ICs & integrated circuits \\
\hline ICT & information and communication technologies \\
\hline IL & Inclusion List \\
\hline IMF & International Monetary Fund \\
\hline IT & information technology \\
\hline ITC & industrial technological capabilities \\
\hline JNTO & Japan National Tourist Board \\
\hline JSFTA & Japan-Singapore Free Trade Agreement \\
\hline $\mathrm{KBE}$ & knowledge-based economy \\
\hline LDC & lesser developed countries \\
\hline M\&As & mergers and acquisitions \\
\hline MAS & Monetary Authority of Singapore \\
\hline MDC & Multimedia Development Corporation, Malaysia \\
\hline MERCOSUR & free trade association in Latin America, comprising \\
\hline & $\begin{array}{l}\text { Argentina, Brazil, Paraguay, Uruguay and associate } \\
\text { members Bolivia and Chile }\end{array}$ \\
\hline MNC & multinational corporation \\
\hline $\mathrm{MoPH}$ & Ministry of Public Health, Thailand \\
\hline MPKSN & $\begin{array}{l}\text { Malaysia National Council for Scientific Research and } \\
\text { Development }\end{array}$ \\
\hline MSC & Multimedia Super Corridor, Malaysia \\
\hline NAFTA & $\begin{array}{l}\text { North American Free Trade Agreement, comprising } \\
\text { Canada, Mexico and the USA }\end{array}$ \\
\hline NBFI & non-bank financial institution \\
\hline
\end{tabular}


NEER

NESDB

NGO

NIC

NIFA

NISTPASS

NPL

NSDB

NSTB

NSTP

NTB

NWC

OCA

OECD

PAS

PIDS

QR

R\&D

REER

REMU

RSE

S\&T

SBI rate

SMEs

SOE

SPSB

STAND

STB

STMP

TEL

UAP

UMNO

UNDP

UNESCAP

UNESCO

WTO nominal effective exchange rate

National Economic and Social Development Board, Thailand

non-government organization

newly industrializing country

National Innovation Framework for Action, Singapore

National Institute of Science and Technology Policy and Strategic Studies

non-performing loan

National Science and Development Board, the Philippines

National Science and Technology Board, Singapore

National Science and Technology Plan, Singapore

non-tariff barriers

National Wage Council, Singapore

optimum currency area

Organization for Economic Cooperation and Development

Parti Islam SeMalaysia

Philippine Institute of Development Studies

quantitative restrictions

research and development

real effective exchange rate

Regional Economic Monitoring Unit

research scientist and engineer

science and technology

Central Bank of Indonesia security rate

small-to-medium enterprises

state-owned enterprise

Singapore Productivity and Standards Board

Science and Technology Agenda for National Development, the Philippines

Singapore Tourism Board

Science and Technology Master Plan, the Philippines

temporary exclusion list

unprocessed agricultural products

United Malays' National Organization

United Nations Development Programme

United Nations Economic and Social Commission for Asia and the Pacific

United Nations Educational, Scientific and Cultural

Organization

World Trade Organization 



\title{
Introduction
}

\author{
Fredrik Sjöholm and Jose Tongzon
}

Southeast Asia's economic development over the last decades has been impressive. Most of the region has achieved consistently high growth rates accompanied by significant structural transformation and industrialization, poverty alleviation and improvements in the overall standard of living as indicated by such social indicators as greater longevity, more widespread delivery of basic education and lower infant mortality rates. However, the crisis that struck Southeast Asia in 1997 had severe economic, social and political consequences for many countries in the region, particularly in the hardest-hit economies of Thailand, Indonesia and Malaysia. It also threw into doubt the future economic prosperity of countries in the region and raised intriguing questions about the quality of their institutions and their approach to economic development.

Economic growth is driven by factor accumulation and technological progress; the more factors of production that are available in a country or the more efficiently these are combined, the higher the country's level of income. Factor accumulation and investment in new technology are in turn dependent on a host of factors often referred to as a country's institutions. The term "institutions" can be broadly defined as the formal and informal rules that shape the nature and extent of human interactions (North 1990). There are also narrower definitions of institutions that focus on specific organizational entities, procedural devices and regulatory frameworks. At a more intermediate level, institutions are defined in terms of the degree of property rights protection, the degree to which laws and regulations are fairly applied, and the extent of corruption. Protection of property rights and enforcement of contracts are referred to as market-clearing institutions, and markets either do not exist or perform very poorly in their absence. Long-term economic development also requires efforts to build three other types of institutions to sustain the growth momentum, build resilience to shocks, and facilitate socially acceptable burden-sharing in response to such shocks. These are marketregulating institutions (those that deal with externalities, economies of scale and imperfect information), market-stabilizing institutions (those that ensure low inflation, minimize macroeconomic volatility and avert 


\section{Introduction}

financial crises) and market-legitimizing institutions (those that provide social protection and insurance, involve redistribution and manage conflicts). All these different forms of institutions are presumably important to ensure sustained economic growth (Keefer and Knack 1993).

The importance of good institutions for economic development is confirmed in a number of empirical studies, where the level of economic development, as measured by per capita income, is closely related to differences in the quality of institutions (Keefer and Knack 1993, North 1995, Barro 1997). The reason seems to be, again, that good institutions increase factor accumulations and technological change. By the same argument, institutional deficiencies will reduce investment and the ability of countries to, for instance, absorb technological advances from abroad. Without institutional advances, countries will have a slower economic growth rate.

Southeast Asia's experience confirms the importance of good institutions for economic development. It seems fair to say that government involvement in institutional development in the Southeast Asian countries has been more pronounced, and sometimes also more efficient, than in most other developing countries (MacIntyre and Jayasuriya 1995). ${ }^{1}$ Most governments in the region have developed market-clearing institutions, opened up their economies to international trade and capital, and limited domestic price distortions. It is of course important to stress the heterogeneity of Southeast Asia, and the nature of government involvement has differed substantially between countries in the region. For instance, government involvement was for a long time excessive, and economically inefficient, in the former centrally-planned economies in the region. The liberalization starting in Vietnam in the mid-1980s, and later followed by Laos and Cambodia, has made these countries converge towards the market-based economies. However, the market-based economies in Southeast Asia are characterized by a relatively large degree of government involvement. As an example, Singapore, the most developed country in Southeast Asia, has a government that actively manages the economy and society to an extent that is not seen in any other high-income country in the world. Government involvement in the region is not restricted to institutional aspects, but often includes a relatively greater participation in production through state-owned enterprises as well as an active role in the allocation of resources to sectors that are regarded as important or strategic. How successful such policies have been is highly debatable. The main success of the governments in the region has presumably been a reasonable maintenance of law and order and the formulation and implementation of policies to achieve macroeconomic stability. The foundation of such stability seems to have been a major factor behind the strong economic performance of Southeast Asia (World Bank 1993).

However, the Asian crisis revealed that many of the institutions that enabled Southeast Asia to grow and develop rapidly in the initial stages of 
economic development were not adequate for providing sustained growth in the midst of increased globalization and competition, and as the countries' levels of economic development increased (Kokko and Sjöholm 2002). Paradoxically, the crisis was partly caused by the same factors that previously fuelled the high growth and development. For instance, the supply of credits increased drastically, partly as a consequence of a deregulation of the financial markets: domestic banks were allowed to expand their credit stocks and foreign capital began to flow into the region on a large scale. Hence, globalization contributed to an increased supply of credits, which in turn spurred investments, industrialization and economic growth. Unfortunately, various institutional weaknesses meant that some of the capital was allocated to speculation on land and stocks rather than being invested in more productive activities. More specifically, weak regulations and inadequate supervision of financial markets in the region, together with poor corporate governance, made it difficult to detect the emerging bubble.

The strong links between government and business interests have been one important aspect of Southeast Asia's industrialization. For instance, the close ties reduced the impact of market failures and the cost of credits, and made it possible for countries to mass mobilize resources at an early stage of development. However, it also led to irresponsible firm behavior, since it was widely assumed that the government would bail out the companies if they ran into problems.

Similar problems were present in the financial sector, which suffered from "crony capitalism" and was the sector most seriously affected by the crisis. The financial sector's development did not keep pace with industrial and technological growth and countries in the region lacked correcting market mechanisms and transparency in business transactions. Consequently, much domestic investment was allocated to economically unsound projects backed by politically well-connected domestic investors. Also equity markets were poorly regulated and did not require high levels of corporate disclosure or strong prohibitions against insider trading and other unfair practices.

Other institutional weaknesses also contributed to the emerging crisis. For instance, there was a general inability to restrain the overheating economies by use of restrictive fiscal and monetary policies. Moreover, the exchange rate arrangement with fixed or semi-fixed currencies, which had previously served the countries well by providing stability in their export expansions, made it also increasingly difficult for them to compete when their currencies appreciated together with the US dollar in the 1990s.

The slow-down in exports in 1996 seems to have triggered the crisis by making foreign investors aware of the structural problems in the region. As a result, foreign banks and investors stopped rolling over loans, which, together with the capital flight from domestic actors, forced through the depreciations of the regional currencies. The depreciations triggered, in 


\section{Introduction}

turn, a severe debt crisis since firms often had a large amount of loans in foreign currencies.

The crisis affected the Southeast Asian countries differently. The hardest hit countries were Thailand and Indonesia, but most countries suffered economically from the crisis: the gross domestic product (GDP) decreased, and unemployment and poverty increased. In addition to economic consequences, the crisis also led to great political changes such as the end of Suharto's long rule and the subsequent democratization process in Indonesia, and the power struggle between Anwar Ibrahim and former prime minister Mahathir, as well as the increased support for the Islamic opposition in Malaysia. Finally, the crisis was presumably one cause of the increased ethnic and religious tensions in, for instance, the Philippines and Indonesia.

The transition economies of Cambodia, Laos, Myanmar and Vietnam did relatively well, partly because some of them were not fully integrated into the global economy with, for instance, liberalized capital markets. ${ }^{2}$ Singapore was perhaps the country in the region that managed the crisis best. It seems that Singapore avoided excessive debt and asset bubbles because of its adequate financial disclosure, its well-developed procedures allowing unsuccessful businesses to fail, and its accumulation of enough foreign exchange reserves to finance its international trade (Cheng et al 2000).

The crisis is over but it will presumably continue to affect the region's economic development. For instance, the crisis has underlined the importance for the countries of continuously upgrading and improving their economies. Unfortunately, a number of external as well as internal factors currently cast doubts over Southeast Asia's ability to repeat its past success. Externally, the slow-down in the world economy, the over-supply of electronics, Japan's difficulties in stimulating its economy, and the apparent rise of China as a strong competitor, do little to help Southeast Asia resume its position as a region of very high economic growth.

Internally, many countries in the region have failed to recover and restructure fully from the Asian financial crisis. The affected countries have addressed their institutional weaknesses in different ways, with varying degrees of success. One reason is that various interest groups have sometimes obstructed the reforms. It is also clear that the governments themselves are frequently opposed to reforms that diminish their own influence; some governments realized the need for reforms, but there were also several instances where reforms were only initiated after (turbulent) political changes. Moreover, part of the institutional adjustment has been due to external pressure from, for instance, the International Monetary Fund (IMF) and foreign banks. The government's role after the crisis is likely to decrease in some areas as a result of privatizations, trade liberalization and market deregulations. However, it is also clear that the govern- 
ment's role will increase in areas such as surveillance and regulations of markets.

The economies of Southeast Asia need to reform their institutions if the previous rapid development is to continue. In the early stages of a country's development, growth can presumably be achieved despite relatively weak institutions. However, the need for good institutions increases as countries develop and growth becomes more dependent on technological progress rather than on factor accumulation. As noted by North (1995), however, creating a flexible institutional system that adjusts to evolving technological and demographic changes as well as to shocks to the system is not an easy task for any society, especially if this is to be carried out in a short period of time (Kokko and Sjöholm 2002). Moreover, the new institutional matrix that will emerge in Southeast Asia is not likely to replicate the Anglo-American or any other existing system, but will instead be based on the region's own unique culture, tradition and experiences. Against the backdrop of Southeast Asia's importance to the world economy, it is hardly possible to overestimate the need to understand this process of change. However, whereas the literature on the economies of Southeast Asia in general, and on the Asian crisis in particular, is extensive, few studies have examined institutional changes in the region since the crisis in $1997 .{ }^{3}$ This volume contributes to the literature by examining the institutional changes taking place and the challenges facing the region since 1997. The book focuses on determinants to the adjustments and implementation of the changes, and various differences between countries in the region. It also re-examines the implications of the crisis for economies and institutions, and evaluates the key challenges facing these countries in the aftermath of the crisis.

The book is organized as follows. Chapter 1 introduces the book's main theme by highlighting the important role of transitional costs in the context of institutional adjustments and transformation. It concludes that an institutional transition can only be justified if the reduction in transaction costs more than compensates for transition costs involved and that many institutional reforms fail because they ignore or underestimate the aspect of transition cost.

Chapter 2 evaluates the educational reforms and challenges facing Southeast Asia. By focusing the analysis on the experiences of Singapore, Malaysia and Indonesia, this chapter highlights the urgent need for these countries to move up the production ladder in the context of growing international competition and rising labor costs. More precisely, as Southeast Asia's traditional export of relatively low-skilled products is facing increased competition, there is a general need to upgrade the production in the region, requiring a more skilled and educated labor force. Historically, education has not been emphasized in Southeast Asia but there are indications that this is about to change. This chapter starts with a general discussion on education in the region and then continues with a close 


\section{Introduction}

look at some of the obstacles to reform, such as financial or political constraints, that are present in the countries in focus.

Chapter 3 highlights the importance of technological development for sustainable growth and development in Southeast Asia. It describes the shortcomings that existed in the technology regimes before the Asian crisis and the changes in these regimes after the crisis. While a debate is raging on the relative importance of factors that contributed to the financial crisis, a major line of thought is that many countries lacked a solid basis for sustained economic development by primarily relying on expanding inputs of more capital and labor. The corollary is that technological development was neglected and this chapter analyzes the problem in two sections. First, it highlights some of the characteristics in science and technology regimes in the region, with a particular focus on the Philippines, Indonesia, Vietnam, Malaysia and Singapore. A second section discusses the shortcomings that existed in the technology regimes and the changes which have taken place since the financial crisis. The analysis focuses on the interaction between the public and private sectors, as seen in the context of an ongoing globalization process.

Chapter 4 assesses the effectiveness of Indonesia's monetary policy in the post-crisis period. It is argued that an ineffective monetary policy seems to have been one reason for the slow recovery process in Indonesia. The chapter continues to discuss the implications of the three possible policy choices - exchange rate policy, interest rate policy and base money policy - still the source of policy debates in the country several years after the crisis. The objectives of the different policy choices and their implications on the overall macroeconomic agenda of the domestic economy are analyzed. Finally, the chapter evaluates the implications of the choices on the overall restructuring process of the banking sector.

Chapter 5 examines the social impact of the crisis, drawing on the results of studies in two countries, Singapore and Thailand. The crisis interrupted three decades of economic growth that had been accompanied by remarkable progress in poverty reduction and an improvement in social indicators like health and education. It is seen that absolute poverty became more acute in Thailand after the crisis. Moreover, with increased unemployment and decreased real wages, income inequality increased both in Singapore and Thailand. This chapter also examines the effects of the crisis on other social indicators, such as school enrollment and health. It concludes that the crisis has exposed significant limitations in the ability of social safety nets to cope with a negative shock of this magnitude, and manifested the need for better targeting to help households tide over their difficulties.

Chapter 6 continues on the poverty theme by examining the role of institutions in safeguarding the capabilities of the poor in Thailand, during the time of economic distress that followed the Asian financial crisis. Unlike previous literature, which tends to focus on the macro-level, 
this chapter addresses macro-micro linkages in pro-poor policies. Similarly, while the social consequences of the crisis have been explored in chapter 5, this chapter examines the institutional environment for propoor growth.

Chapter 7 assesses the implications of Singapore's initiatives to forge extra-ASEAN free trade agreements for the future of ASEAN economic integration. It addresses the question of whether the recent crisis and the resulting economic difficulties undermined ASEAN's resolve to deepen their level of economic integration. It also tries to shed light on Singapore's current initiative to forge free trade deals with countries outside the region and its likely implication for the region's economic integration. The perception by some members in ASEAN that these bilateral free trade deals can be used as a "backdoor" entry into the ASEAN markets is a matter of serious concern, which could threaten the very existence of ASEAN as a regional economic grouping.

Chapter 8 re-assesses the prospects for greater monetary integration in Asia. The Asian crisis highlighted the absence of well-developed supranational institutions in Asia to either prevent or deal with currency and balance of payments problems. The chapter discusses a number of initiatives since 1997 to enhance monetary cooperation in the region including Japan's proposals for an Asian Monetary Fund, the Chiang Mai Initiative at the ASEAN+3 meeting in May 2000, the Kobe Research Project, and the currency swap agreements and surveillance machinery initiated at the Asian Development Bank Meeting in Honolulu in May 2001. It argues that the economic preconditions for further integration are not as daunting as one might expect, but that it seems unlikely that the institutional structures and political will in Asia are strong enough to provide the basis for significant monetary integration in the forseeable future.

\section{Notes}

1 The government involvement might have been even larger, or at least of different character, in Northeast Asia (MacIntyre 1994, Rodan et al. 1997).

2 However, they were affected by the crisis indirectly through their trade and investment linkages with the other crisis-hit countries in the region.

3 For books on the economies and institutions in Southeast Asia see, for example, Tongzon (1998), Barlow (1999), Woo et al. (2000) and MacIntyre (2003). See also Drysdale (2000) for a description on some reforms taking place in East Asia after the crisis.

\section{References}

Barlow, C. (ed.) (1999) Institutions and Economic Change in Southeast Asia: The Context of Development from the 1960s to the 1990s, Northhampton, Mass.: Edward Elgar. 


\section{Introduction}

Barro, R. (1997) Determinants of Economic Growth: A Cross-country Empirical Study, Cambridge, MA: MIT Press.

Cheng, Y.S., Chia, S.Y. and Findlay, C. (2000) "Governance in the city-states: HongKong and Singapore”, in P. Drysdale (ed.) Reform and Recovery in East Asia, London: Routledge.

Drysdale, P. (ed.) (2000) Reform and Recovery in East Asia, London: Routledge.

Keefer, P. and Knack, S. (1993) "Why don't poor countries catch up? A crossnational test of an institutional explanation", Working Paper No. 60, Center for Institutional Reform and the Informal Sector, University of Maryland at College Park.

Kokko, A. and Sjöholm, F. (2002) "Economic recovery in Southeast Asia", Stockholm: Stockholm School of Economics.

MacIntyre, A.J. (1994) "Business, government and development: Northeast and Southeast Asian comparisons", in A.J. MacIntyre (ed.) Business and Government in Industrializing Asia, St Leonards: Allen \& Unwin.

(2003) The Power of Institutions: Political Architecture and Governance, Ithaca: Cornell University Press.

MacIntyre, A.J. and Jayasuriya, K. (1995) The Dynamics of Economic Policy Reform in South-East Asia and the South-West Pacific, Kuala Lumpur: Oxford University Press.

North, D.C. (1990) Institutions, Institutional Change and Economic Performance, New York: Cambridge University Press.

(1995) "The New Institutional Economics and Third World Development", in J. Harriss, J. Hunter and C.M. Lewis (eds) The New Institutional Economics and Third World Development, London: Routledge.

Rodan, G., Hewison, K. and Robison, R. (eds) (1997) The Political Economy of SouthEast Asia, Oxford: Oxford University Press.

Tongzon, J. (1998) The Economies of Southeast Asia: The Growth and Development of ASEAN, London: Edward Elgar.

Woo, W.T., Sachs, J. and Schwab, K. (eds) (2000) The Asian Financial Crisis: lessons for a resilient Asia, Cambridge, MA.: MIT Press.

World Bank (1993) The East Asian Miracle: Economic Growth and Public Policy, New York: Oxford University Press. 


\title{
1 Institutional transition and transition cost: a methodological consideration
}

\author{
Jang-Sup Shin
}

\section{Introduction}

It has often been argued that developing countries should change their institutions into some idealized institutions, if they earnestly want to get out of the vicious circle of poverty or to overcome setbacks in the course of their economic development. The so-called "Washington consensus" is a typical example of this view, in which a standard set of institutions is recommended equally to any developing country because it is presumed to ensure the most desirable path of economic development. ${ }^{1}$

After the 1997 financial crisis in East Asia, there have also been numerous calls from international organizations and researchers for an overhaul of the malfunctioning institutions in the region, and some countries actually carried out broad institutional reforms in their attempts to overcome the crisis. For the reformers, however, institutional changes in these countries often appear too slow and seem to be hindered by many obstacles. There is also growing dissent from other segments in these countries over the direction and pace of institutional changes already set in motion.

This chapter highlights methodological reasons why institutional changes arouse such controversies and are more often than not resisted. It argues that this is mainly because there are in fact no "best institutions" in the real world and institutional changes incur transition costs, the size of which varies according to the context within which the changes occur.

The chapter starts from critically assessing North's analysis $(1981,1990)$ of relating transaction cost and economic performance, the underlying methodology of which is adopted in most reform programs in developing countries, and points out the fallacy of connecting transaction cost, i.e. static system management cost, directly to the need of institutional changes in those countries. It then argues that Khan's (1995) "transition cost" should be considered separately from transaction cost in designing and implementing institutional change. If we consider transition cost, an institutional transition can be justified only if the reduction in transaction cost more than compensates for the transition cost involved. The chapter also compares institutional transitions in Malaysia and South Korea 


\section{Institutional transition and transition cost}

(henceforth referred to as Korea) after the Asian financial crisis in view of transition cost by focusing on the functioning of the risk-taking mechanism at the national economy level.

\section{Transaction cost economics and economic performance}

Transaction cost economics, often categorized under "new institutional economics", has drawn broad interest among economists and economic historians because of some new aspects in its approach. A long line of institutional economists had failed to produce a common conceptual framework to analyze institutions; the consensus reached agreed on the importance of institutions in economic activities and the need for incorporating institutions in economic analysis. But the novelty of transaction cost economics lies in its attempt to explain institutions with a common concept, i.e. transaction cost, and analyze them with the tools employed in conventional economics. ${ }^{2}$ The existence of and changes in institutions can be explained in terms of transaction cost economizing behavior of individuals. For instance, Williamson (1985: 1) argues that economic institutions "have the main purpose and effect of economizing on transaction cost”. North also maintains that a country's successful economic performance can be attributed to its institutional structure that keeps its transaction costs low.

In understanding transaction cost economics, it is important to note that it started basically from an attempt to rectify deficiencies in the concept of production cost in standard neo-classical economics. According to Williamson, "[p] retransaction-cost economics [i.e. neo-classical economics] takes the organization of economic activity as given and characterizes firms as production functions with a motive of profit maximization" (1985: 199) whereas "transaction cost economics maintains ... that organizational variety arises primarily in the service of transaction cost economizing" (1985: 387). North also separates transaction cost from "transformation cost" which is almost identical to production cost in Williamson's analysis. For both economists, the total cost related to economic activities is the sum of production (or transformation) cost and transaction cost.

However, by taking the neo-classical production function as its reference point, transaction cost is defined as costs related to "frictions" (Williamson 1985: 18-19), or costs involved in "economic exchange" (North 1990: 27), which do not appear in the standard production function. The contents of transaction cost are therefore specified as a residual of those of production cost. ${ }^{3}$ For Williamson (1985: 20-22), they are the costs related to a contract both ex ante and ex post. For North (1990: 28), they are all the costs incurred in "defining, protecting and enforcing the property rights to goods (the right to use, the right to derive income from the use of, the right to exclude, and the right to exchange)", as compared 
to the costs incurred in "transforming the physical attributes of goods (size, weight, color, location, chemical composition, and so forth)". North emphasizes the importance of transaction cost in the national economy with a calculation that more than 45 percent of the U.S. national income is currently devoted to transacting activities.

Apart from considering this hidden cost, transaction cost economics is based on the rational choice of individuals, the same as in neo-classical economics; what drives its system is the cost minimizing (or utility maximizing) behavior of individuals. In this regard, North (1990: 83) asserts that " $[\mathrm{t}]$ he agent of change is the individual entrepreneur responding to the incentives embodied in the institutional framework". Institutional change is therefore understood as a consequence of voluntary contracts and a major impetus here is the change in relative prices. ${ }^{4}$ Like in the world of neo-classical economics, it is also assumed that institutional change driven by the rational choice of individuals would lead to an ideal institution, if free negotiation over contracts is ensured.

In the real world, however, there are many obstacles that hinder institutional change towards efficiency improvements. North refers to the force behind those obstacles as "path-dependence" and argues that institutional change occurs incrementally or at the margin due to the path-dependence. For North, the most important factor in determining path-dependence is the political market because " $[\mathrm{t}]$ he polity specifies and enforces the property rights of the economic marketplace..." (1990: 109). Then, he boldly concludes, "[ $\mathrm{t}]$ he condition [for political market to approximate to the zero transaction cost model for efficient economic change] is easily stated" and that this "is a modern democratic society with universal suffrage" (1990: 109, emphasis added). He supports his argument with a comparison between the British-North American path and the Spanish-South American path of economic development. He also applies this conclusion to a comparison of economic performance between the First World countries and the Third World countries.

How successful is the project of transaction cost economics? Let me answer this question by focusing on its methodological underpinnings.

First, although transaction cost economics originated from dissatisfaction with neo-classical economics, it accepts the inherent efficiency of the neo-classical world. By measuring the size of frictions from this reference point, transaction cost economics therefore presumes to compare economic performance of different institutions on an absolute scale. This attempt is, however, subject to some serious methodological flaws.

For instance, as "the second-best theorem" in welfare economics shows ${ }^{5}$ a world with one distortion is not necessarily more efficient than one with two or more distortions even within the neo-classical framework. The size of friction thus does not give a definite efficiency implication. The issue of dynamic efficiency has also yet to be resolved in the neo-classical framework and a short-term friction-minimizing institution is not 


\section{Institutional transition and transition cost}

necessarily the best performing one in the long term. Lucas (1988: 12) pinpoints in this regard that there is no guarantee that the pursuit of allocative efficiency will bring about growth effects, although it has level effects. ${ }^{6}$ Moreover, for those who do not accept the efficiency of the neoclassical world, comparing the real world to the neo-classical world does not make any sense.

Second, transaction cost economics resorts to use of residual analysis; the focus of the analysis is the residual of production function on the supposition that the determinants of production function are separate from those of the residual. North (1990: 27) argues that changes in transformation cost are basically affected by technological change whereas changes in transaction cost are influenced by institutional change; therefore, if we add a theory of production to his theory of transaction cost, "we can then analyze the role of institutions in the performance of economies". In this way, efficiency of institutions can be analyzed by exclusively focusing on transaction cost.

However, North neglects the possibility that transaction cost can be interrelated to production cost. As neo-Schumpeterian studies of national innovation systems demonstrate, ${ }^{7}$ institutions also critically affect production function, i.e. technology. If we take this view, developing a theory that deals with both production and transaction cost at the same time becomes the crucial issue, rather than adding one theory to the other.

Third, transaction cost economics adopts reductionism in its actual analysis; complex factors determining the efficiency of institutions are progressively reduced to certain ultimate factors. They are reduced to transaction cost, separated from production cost in the first place. The determinants of transaction cost, especially those of path-dependence, are then reduced to the political market. North again reduces determinants of the efficiency of the political market to the possibility of free negotiation over contracts.

However, there is also path-dependence resulting from economic variables and this has important implications in comparing economic performance across countries as well as designing institutional change, as shall be discussed in detail in the section on comparison between Korea and Malaysia. This aspect is neglected in North's analysis because he excludes production function from his institutional analysis. It is also the case that, even in the most democratic polity, compensations to losers are not sufficiently made, or efficiency-enhancing institutional changes are blocked by interest group politics.

Considering the deficiencies discussed above, the only support given to North's conclusion is his comparison between the British-North American path and the Spanish-South American path of economic development. However, since his case study is not exhaustive, it is not difficult to find cases to contradict his conclusion merely by looking outside his comparative setting. For instance, the economic recovery of France after the end of World War II was carried out with sweeping nationalization, i.e. by 
limiting individuals' freedom to negotiate over contracts. ${ }^{8}$ Chang (1994) argues, by employing the very concept of transaction cost, that the state intervention in Korea contributed to reducing, rather than increasing, transaction costs. As Mathews (1986: 907) points out, it is therefore not unnatural that transaction cost economics "has been invoked in support of both market pessimism and market optimism".

This is fundamentally because there is no such thing as the most efficient institution in the real world, by deviations from which we can gauge relative efficiency of other institutions. Any institution has its own merits and demerits, and its net efficiency is indeterminate without considering the context within which it operates. As shall be elaborated further below, the main difficulty as well as the significance of institutional analysis lies in the lack of an absolute reference point and the need to investigate the context by use of comparison. By ignoring this fundamental aspect, North attempts to provide a universal theory of institution and institutional change, and inevitably relies on reductionism and residual analysis.

\section{Transition cost and system transition}

Although we are not able to define the most efficient institution in absolute terms, it is possible to compare the relative efficiency of institutions at a given time and among a limited number of countries. For instance, when the Japanese economy outperformed the US economy in the 1970s and 1980s, we can trace reasons for the different economic performance between the two countries to their differences in institutions. Likewise, in understanding the resurgence of the US economy and the stagnation of the Japanese economy during the 1990s, we may find some institutional reasons for the different performance between the two countries. Similarly, it also makes good sense to compare institutions of East Asian countries with those of Latin American countries if we want to investigate the reasons behind their different economic performance during the last few decades. Most studies on institutions and economic performance are actually undertaken in this manner.

What should be noted is that this kind of institutional comparison is basically static. During a given period, it is assumed, implicitly or explicitly, that the major institutional features of the countries in question remain the same and those features are attributed to explaining performance. If those features are fluid, it is difficult to characterize institutions and to attribute them to performance. This static analysis is the beginning of any institutional analysis and it is certainly very useful. By relating institutional features to performance, we can draw meaningful conclusions on the important characteristics of well-functioning institutions, the reduction of a system's maintenance cost, the potential improvements for poorly-functioning institutions, and so on. 


\section{Institutional transition and transition cost}

However, in designing institutional change, this consideration of static aspects, though necessary, is not sufficient. Let us suppose that a system (S1) performed better than another one (S2) during a certain period. We may explain that $\mathrm{S} 1$ had lower cost than $\mathrm{S} 2$, or conclude that $\mathrm{S} 1$ was superior to S2. But the superiority of S1 itself does not necessitate for S2 to make a transition to $\mathrm{S} 1$, because an additional cost consideration is required in changing a system. If the cost involved in shifting S2 to S1 more than offsets the expected benefit of lowering the cost of S2, it is not desirable to make such a transition.

Khan (1995) names this cost involved in institutional transition as "transition cost" and argues we should treat this separately from transaction cost. North does not seriously consider transition cost because, in emphasizing the importance of path-dependence, he sees institutional change predominantly as changes at the margin. Path-changing institutional changes, i.e. changes in characteristic features of institutions, are precluded in this perception. As regards forces influencing path-dependence, North (1990: 95) vaguely refers to "increasing returns" and "market imperfections", citing Arthur (1989), but he does not elaborate on them except saying that changes in paths "will typically occur through changes in the polity" (1990: 112).

Khan (1995: 82) rejects this North-type view of institutional change through voluntary negotiations as follows:

But in fact important real world institutional changes are rarely accompanied by the compensation of losers. Human history may not be a history of class struggle alone but it is certainly not a history of negotiated institutional change. Modelling institutional change "as if" it were a negotiated process with compensation allows the importation of sophisticated tools ... but makes the analysis seriously deficient. Real-world institutional change involves path changes. These are discontinuous breaks in the paths ... Even relatively minor institutional changes such as changes in tax rates are typically not negotiated through compensating side-payments.

Khan defines transition cost as "the political cost faced by initiators of new institutions" (1995: 81), or "the political cost which potential losers from a proposed institutional change can impose on the proponents" (1995: 82), and argues for placing the concept of transition cost at the center of the analysis of institutional change.

For Khan, the most important determinant of transition cost is political settlement, which is "the balance of power between the classes and groups affected by ... [a given] institution" (1995: 77), because the cost depends critically on the "intensity and extent of resistance" by losers. But it is difficult to measure the cost quantitatively because it is often "inflicted on a specified group by political events such as physical violence or defeats in 
elections" (1995: 82). The size of transition cost is also institution-specific because political settlement is diverse across countries and therefore costs arising from resistance to proposed institutional change are different due to differences in the existing political settlements in question.

In this situation, the best an initiator of a transition can do is to make "the [subjective] ranking of composite bundle of costs" associated with alternatives in hand, and to choose a strategy for transition accordingly (1995: 83). In this process, the strategies that could incur too high transition costs are eliminated from the list of feasible options. Khan (1995) illustrates this point with the case of the unsuccessful attempt by the Pakistani government to establish a developmental state in the 1960s. ${ }^{9}$

Acknowledging the existence of transition cost makes a great difference in understanding and designing institutional transitions. Above all, it leads us to the fact that no institutional change can be undertaken independently of the country's history. Countries have differing historical backgrounds and transition costs involved in their path changes will inevitably differ among them. Modeling idealized institutions or best-performing institutions (in the real world), therefore, does not necessarily bring about better performance for individual countries.

\section{Economic transition cost: a comparison between Korea and Malaysia}

While Khan proposes the concept of transition cost mainly in relation to political costs involved in institutional change, I will add here an economic dimension to transition cost. This is mainly because economic institutions of a country are also products of their own historical development, and therefore closely intertwined with other related components of the economy such as composition of industries, developmental stage and the historical heritage of the country, which cannot be changed overnight. When a radical institutional change is attempted, it is therefore possible that it may conflict with other related components of the economy, resulting in economic costs. I will illustrate this point below with a comparison of institutional transitions in Malaysia and Korea after the 1997 financial crisis by focusing on the risk-taking mechanism at the economy level.

Both countries encountered a financial crisis and recovered from it almost at the same time. In the process of combatting the financial crisis, however, they employed diametrically opposed approaches to institutional transition. Korea called on the International Monetary Fund (IMF) for intervention and carried out far-reaching institutional reforms, following the idealized Anglo-American model. By contrast, Malaysia rejected the IMF program and revived the economy in its own way by introducing selective capital controls and maintaining its major economic institutions, although it had to undertake some institutional adjustments to deal with bad loans accumulated in its economic system. 


\section{Institutional transition and transition cost}

Radical institutional changes in Korea under IMF stewardship involved a fundamental shift in the country's risk-taking mechanism. The earlier system in Korea can be characterized as a state-mediated one; the state controlled cross-border financial flows by use of discretionary policy measures. It also managed financial risks in the domestic economy not only by regulating financial institutions but also by regulating industrial corporations with industrial policy tools. However, the IMF-sponsored reforms after the crisis instituted a system in which the state confines itself to financial supervision by adopting the so-called global standard financial regulations like forward-looking criteria (FLC), the Bank for International Settlements capital adequacy ratio (the BIS ratio) rules and so on; the market, in particular the foreign investors and domestic financial institutions, plays a central role in the risk management of the economy.

In this system, complete liberalization is a target and the Korean government abolished almost all of the remaining regulations over crossborder financial flows. Gaining investor confidence was also regarded as crucial in reducing the financial vulnerability of the economy and the Korean government endeavored greatly to provide foreign investors with favorable investment environments. It was also thought that domestic financial institutions would become as healthy as possible if they could make independent financial decisions. For this purpose, the Korean government attempted to dispose of non-performing loans (NPLs) in the financial institutions as quickly as possible.

In contrast, Malaysia did not undertake this kind of radical system change. The state maintained its role as a financial risk manager in its economy. In fact, it strengthened its controlling power over cross-border financial flows by introducing selective capital controls. Although it began publishing statistics on NPLs according to the IMF's 3-months classification standards in a move to increase transparency in its financial system, it still used the earlier 6-months classification standards as a major indicator of NPLs. Moreover, the soundness of the financial sector itself was not given exclusive attention and the disposal of NPLs was not carried out in haste. The overall focus of Malaysia's restructuring policy lay in preserving values of its own assets and maintaining employment.

Despite initial skepticism and criticism of the Malaysian approach from international organizations and many scholars, Malaysia's recovery from the crisis was as complete as Korea's. The two economies experienced a sudden contraction in 1998 and showed rapid expansion in 1999 and 2000 before slowing down with the global recession in 2001. Korea's average gross domestic product (GDP) growth rate during the recovery period (7.7 percent) was certainly higher than that of Malaysia (4.9 percent). However, this should not be read as an indication that the Korean approach to institutional change was superior to that of Malaysia. For the difference is mainly due to Korea's stronger Keynesian reflation- 
ary policies, including monetary and fiscal expansion, to combat deflationary pressure after the financial crisis. ${ }^{10}$

However, Malaysia achieved this recovery with much less cost to its economy than Korea. It seems that the radical institutional transition in Korea created a vacuum in the risk-taking function at the level of the economy, resulting in a large transition cost. Malaysia, by contrast, did not need to pay these transition costs because it maintained its previous institutional structure, even though it had to spend a substantial amount of money to deal with the financial troubles in the wake of the financial crisis. I will discuss these differences in transition costs between the two countries under the following headings: Costs in managing open capital account, Costs in selling domestic assets to foreign investors, and costs in disposing of NPLs outside the financial system.

\section{Costs in Managing open capital account}

If a country opens its capital account to cross-border international financial flows, maintaining large foreign reserves is the last resort to protect its economy from possible currency attacks. Considering the number of currency transactions in the international financial market, foreign reserves themselves can never be a safeguard against currency speculation. However, it is necessary for an economy to increase foreign reserves as it becomes more vulnerable to possible currency attacks once it abandons regulatory measures to control financial flows.

Malaysia did not need to beef up its foreign reserves because it insulated its economy from possible speculative currency attacks by introducing capital controls. Malaysia's total foreign reserve only increased from US $\$ 269.2$ billion at the beginning of 1997 to US $\$ 304.7$ billion at the end of 2001. In contrast, Korea had to increase its foreign reserves enormously by completely liberalizing its capital account following the IMF program. Its total foreign reserves, which stood at US $\$ 317.4$ billion at the beginning of 1997 , more than tripled to US $\$ 1,027.5$ billion at the end of 2001 .

Whether this large sum of foreign reserves made Korea less vulnerable to currency attacks than Malaysia would be an open question, and, to my knowledge, there is no convincing proof of this. However, the opportunity cost of maintaining larger foreign reserves should be counted as a part of the transition cost involved in Korea's institutional transition towards fullfledged financial liberalization.

\section{Costs in selling domestic assets to foreign investors}

Malaysia was able to overcome the crisis by selling fewer assets to foreign investors compared with Korea. Since Malaysia also faced a severe liquidity crunch during the crisis, it had to sell some of its own assets to ease financial constraints. Reflecting this, Malaysia's asset sales through mergers and 


\section{Institutional transition and transition cost}

acquisitions (M\&As) jumped nearly threefold after the financial crisis compared with before the crisis. The annual average of M\&A sales, which was US $\$ 336$ million during the pre-crisis period (1991-1997), rose to US\$927 million during the post-crisis period, 1998-2002 (see Table 1.1).

However, these figures look pale when compared to those of Korea. Korea's annual average of M\&A sales was US $\$ 324$ million in 1991-1997 before the crisis, smaller than that of Malaysia. But it increased by more than 18 times to US\$5,901 million during the period after the crisis, 1998-2002. This is because the Korean government and the IMF put great emphasis on the inflow of foreign money as a sign of regained investor confidence, which they thought shattered with the financial crisis, and applied enormous pressure on Korean corporations and financial institutions to sell their assets to foreign investors. ${ }^{11}$

Although the Korean government and the IMF paint these asset sales, which constituted most of the foreign direct investment (FDI) inflows during the post-crisis period, as a great achievement of their reform program, they

Table 1.1 Cross-border M\&As and FDI inflows in Malaysia and Korea, 1991-2002 (US\$ million)

\begin{tabular}{|c|c|c|c|c|}
\hline & \multicolumn{2}{|l|}{$M \mathcal{E}^{\top} A s^{a}$} & \multicolumn{2}{|c|}{$F D I$ inflows $^{b}$} \\
\hline & Malaysia & Korea & Malaysia & Korea \\
\hline 1991 & 128 & 673 & 3,998 & 1,180 \\
\hline 1992 & 46 & 0 & 5,183 & 727 \\
\hline 1993 & 518 & 2 & 5,006 & 588 \\
\hline 1994 & 443 & 1 & 4,342 & 809 \\
\hline 1995 & 98 & 192 & 4,132 & 1,776 \\
\hline 1996 & 768 & 564 & 4,672 & 2,325 \\
\hline 1997 & 351 & 836 & 6,323 & 2,844 \\
\hline 1998 & 1,096 & 3,973 & 2,714 & 5,412 \\
\hline 1999 & 1,166 & 10,062 & 3,895 & 9,333 \\
\hline 2000 & 441 & 6,448 & 3,788 & 9,283 \\
\hline 2001 & 1,449 & 3,648 & 554 & 3,528 \\
\hline 2002 & 485 & 5,375 & 3,203 & 1,972 \\
\hline Pre-crisis average (1991-1997) & 336 & 324 & 4,808 & 1,464 \\
\hline Post-crisis average (1998-2002) & 927 & 5,901 & 2,831 & 5,906 \\
\hline
\end{tabular}

Source: UNCTAD (2003) World Investment Report 2003, Annex Table B.1 and B.7.

Notes

a The acquisition of an equity stake of more than 10 percent by foreign investors. Figures here are on gross basis. They are also those concluded and announced each year. It is therefore possible that the amount of M\&A sale in a year, say, in 1999 in Korea, can be greater than that of FDI inflow, if some M\&As concluded were paid in later years.

b Including equity capital investment, reinvested earnings, and intra-company loans or debt transactions. Figures here are calculated from the countries' balance of payments statistics on the net basis where debits of capital transactions between direct investors and their foreign affiliates were deducted from credits between them. 
can hardly be regarded as of much benefit to the economy in themselves. It can only be beneficial to the economy if these changes in the ownership of assets are translated into better performance of the economy as a result of the infusion of advanced technologies and management practices. But this potential positive effect of FDI to the economy is not yet in sight.

Moreover, if these assets were sold at heavily discounted prices as a result of distress sales in a crisis situation, the difference between their real value and their sale prices should be counted as costs to the economy, regardless of the size of FDI inflows involved. There is of course no objective way to measure the extent of the distress discount in the sales value of assets. However, it is a common situation after a financial crisis that domestic companies and financial institutions need to sell their assets as quickly as possible to overcome severe liquidity constraints, while foreign investors are in no hurry to buy those assets and can take their time. Considering this asymmetry in negotiation power between domestic institutions and foreign investors, it is more natural to suppose that the assets domestic institutions can sell in a crisis situation will be either those with exceptionally bright prospects or those with bargain prices, or both. In this respect, a substantial part of asset sales in Korea could be regarded as transition costs borne by the country in shifting its economy, which had drawn its investment funds primarily from domestic resources and foreign debts, towards one relying on foreign investment.

One may argue that Malaysia's reduction in the volume of FDI inflows after the crisis is a negative consequence of capital controls and other unorthodox policy measures that made foreigners hesitant to invest in Malaysia. If we simply compare figures of FDI inflows between Malaysia and Korea, this observation may look plausible. In Table 1.1, the annual average FDI inflow in Malaysia was nearly halved during the post-crisis period (US\$2,831 million, 1998-2002) compared to the pre-crisis average (US\$4,808 million, 1991-1997) whereas that in Korea more than quadrupled during the post-crisis period (US\$5,906 million) from that during the pre-crisis period (US $\$ 1,464$ million).

However, the FDI figures for the two countries should be interpreted with great care. As pointed out above, most FDI inflows in Korea after the crisis were accounted for by asset sales and greenfield investments were minimal. It can be even argued that the heavy reliance on asset sales in fact hindered greenfield investments in Korea. During the pre-crisis period, M\&As (US\$324 million) accounted for just over 20 percent of FDI inflow (US $\$ 1,464$ million). However, M\&As amounted to almost 100 percent of FDI inflow during the post-crisis period. ${ }^{12}$ In contrast, Malaysia was able to attract a large number of greenfield investments even after the crisis, though its volume was considerably reduced from before the crisis. Considering this difference in composition of FDI inflows, one cannot simply say that the performance of Korea was better than that of Malaysia in terms of attracting FDI after the crisis. 


\section{Institutional transition and transition cost}

Moreover, the stagnation of FDI inflows after the crisis was a common phenomenon in the Southeast Asian region overall, not simply confined to Malaysia. As China continued its explosive economic growth and maintained its open-door policy, the Southeast Asian region appeared to be losing out in competition with China in attracting FDI inflows. On the other hand, the structure of the Korean economy was more advanced than Malaysia or China, and there was less direct competition with China in attracting FDI. In this respect, the stagnation of FDI in Malaysia can be better regarded as a consequence of the overall deterioration of the regional competitiveness of Southeast Asia, not as a result of a negative impact on investor confidence by Malaysia's rejection of the implementation of neo-liberal institutional reforms.

\section{Costs in disposing NPLs outside the financial system}

Malaysia recovered from the financial crisis by creating fewer NPLs within the economy than Korea. When considering NPLs, most studies only focus on NPLs within the financial sector. The latter is certainly a measure of the soundness of the financial sector; if financial institutions are swamped by NPLs, they have difficulty in functioning as neurons of the economy. It is necessary to limit the level of NPLs in the financial sector for the smooth running of the economy.

However, the reduction in NPLs within the financial sector itself cannot be regarded as a successful achievement of economic restructuring after a financial crisis. For the reduction can be simply achieved by shifting NPLs to outside the financial sector by purchasing them with public funds or selling them to private investors. If we want to evaluate a restructuring process, we need to investigate what happened to the overall number of NPLs at the level of the economy.

Korea's performance in reducing NPLs within the financial sector is indeed remarkable. NPLs in the financial sector, which jumped to 136.3 trillion won (US $\$ 113.5$ billion), or 21.8 percent of total loans at the height of the financial crisis in June 1998, were reduced to 66.7 trillion won (US $\$ 55.5$ billion or 11.3 percent) at the end of 1999 , and to 32.0 trillion won (US $\$ 26.6$ billion or 5.4 percent) at the end of 2001 (see Table 1.2). In the banking sector, the NPL ratio fell dramatically to 3.4 percent at the end of 2001 (FSC website). As far as numerical measures indicating the soundness of the financial sector are concerned, Korea achieved more than what the most optimistic analysts would have forecast.

The performance of Malaysia looks sluggish compared with Korea's. The amount of NPLs in the Malaysian financial sector hardly changed even after the economic recovery. The figure was RM76.9 billion (US $\$ 20.2$ billion) in 1998, the year when the economy had reached the bottom, and still stood at RM76.8 billion (US $\$ 20.2$ billion) in 2001, if one applies the 6-month standards. The NPLs ratio to total loans also did not 
Table 1.2 Trend of NPLs in Malaysia and Korea, 1997-2001

\begin{tabular}{|c|c|c|c|c|c|c|c|}
\hline & & $\begin{array}{l}\text { NPLs in } \\
\text { the } \\
\text { financial } \\
\text { sector } \\
(R M \text { bil. } \\
\mathcal{E}^{2} \text { Won } \\
\text { tril. }) \\
(A)\end{array}$ & $\begin{array}{l}\text { NPLs } \\
\text { ratio to } \\
\text { total } \\
\text { loans } \\
(\%)\end{array}$ & $\begin{array}{l}\text { Accumulate } \\
\text { NPLs } \\
\text { disposed } \\
\text { outside the } \\
\text { financial } \\
\text { system } \\
\text { (RM bil. E } \\
\text { Won tril.) } \\
\text { (B) }\end{array}$ & $\begin{array}{l}B / G D P \\
(\%)\end{array}$ & $\begin{array}{l}\text { Accumulate } \\
\text { NPLs in } \\
\text { the economy } \\
\text { (RM bil. E } \\
\text { Won tril.) } \\
(A+B)\end{array}$ & $\begin{array}{l}(A+B) / \\
G D P(\%)\end{array}$ \\
\hline \multirow[t]{5}{*}{ Malaysia } & 1997 & $\begin{array}{c}35.7 \\
(25.0)\end{array}$ & $\begin{array}{c}8.5 \\
(5.9)\end{array}$ & - & - & 35.7 & 12.6 \\
\hline & 1998 & $\begin{array}{c}76.9 \\
(52.4)\end{array}$ & $\begin{array}{c}18.6 \\
(12.7)\end{array}$ & 14.7 & 4.9 & 91.6 & 30.4 \\
\hline & 1999 & $\begin{array}{c}65.5 \\
(46.8)\end{array}$ & $\begin{array}{c}16.6 \\
(11.8)\end{array}$ & 29.8 & 8.7 & 95.3 & 27.8 \\
\hline & 2000 & $\begin{array}{c}64.2 \\
(49.0)\end{array}$ & $\begin{array}{c}15.4 \\
(11.8)\end{array}$ & 46.5 & 13.9 & 110.7 & 33.1 \\
\hline & 2001 & $\begin{array}{c}76.8 \\
(61.7)\end{array}$ & $\begin{array}{c}17.8 \\
(14.3)\end{array}$ & 63.1 & 17.5 & 139.9 & 38.7 \\
\hline \multirow[t]{5}{*}{ Korea } & 1997 & $\begin{array}{c}86.4 \\
(43.6)\end{array}$ & $\begin{array}{l}13.2 \\
(6.7)\end{array}$ & 28.9 & 6.5 & 115.3 & 25.9 \\
\hline & 1998 & $\begin{array}{l}102.7 \\
(60.2)\end{array}$ & $\begin{array}{c}17.7 \\
(10.4)\end{array}$ & 131.6 & 27.3 & 234.3 & 48.5 \\
\hline & 1999 & 66.7 & 11.3 & 284.2 & 54.5 & 350.9 & 67.2 \\
\hline & 2000 & 64.6 & 10.4 & 442.6 & 80.3 & 507.2 & 91.9 \\
\hline & 2001 & 32.0 & 5.4 & 586.8 & 98.4 & 618.8 & 103.7 \\
\hline
\end{tabular}

Source: Bank Negara Malaysia, Monthly Statistical Bulletin, various issues; Danaharta, Operations Reports, various issues; PFOC, White Paper on Management of Public Funds, various issues; FSC, The Current Status of Non-Performing Loans in the Financial Sector, various issues.

Note

a Figures in parentheses are based on 3-months classification of NPLs. In Malaysia, supervisory regulations over NPLs are based on 6-months classification, although the Bank Negara Malaysia announces figures based on 3-months classification simultaneously. In Korea, the financial authority changed its NPL classification system to that of 3 months from the end of 1999 and no longer announced NPLs based on 6-months system.

b The Malaysian figures were calculated by applying 55 percent of discount rate, which was an average during 1999-2001 for NPLs purchased by Danaharta. The Korean figures were calculated by applying 38 percent of discount rate, which was an average during the period November 1997 and June 2001 for NPLs purchased by the Korean government (PFOC 2001: 138, table 3-34).

improve, changing only slightly from 18.6 percent in 1998 to 17.8 percent in 2001.

However, these figures conceal the amount of NPLs created in the economy. As Table 1.2 shows, the accumulate NPLs in the Korean economy, which include both those remaining within the financial system and those disposed outside the financial system, were 618.8 trillion won 


\section{Institutional transition and transition cost}

(US $\$ 479.3$ billion) in 2001. This means that, during 1998-2001, 503.5 trillion won (US $\$ 390.0$ billion) of new NPLs, equivalent to 84.4 percent of the country's GDP in 2001, was reported in the Korean economy. By contrast, the value of those in the Malaysian economy during the same period was RM104.2 billion (US $\$ 27.4$ billion), equivalent to 28.8 percent of the country's GDP in 2001. The figures show that Korea recovered from the financial crisis by creating a lot more NPLs in its economy than Malaysia, although its financial sector may look much healthier than its Malaysian counterpart.

It is of course impossible to determine objectively how much of the increase in NPLs in the economy was due to ex post realization of latent troubles in the economy accumulated before the crisis, or to difficulties created in the process of overcoming the financial crisis. The reformers in Korea, including the Korean government and the IMF, tend to attribute most of these new NPLs to the former.

However, this view seems far fetched. To be correct, one should be able to say that the Korean economy had been plagued by a much larger scale of hidden financial troubles than the Malaysian economy before the outbreak of the currency crisis in 1997. However, there is no convincing evidence that the scale of latent NPLs in Korea could be as much as over three times that of Malaysia. It would be more plausible to attribute such a big difference in the size of newly accounted NPLs between Korea and Malaysia to their different approaches in dealing with the financial crisis.

In this regard, we need to draw attention to the financial conditions in Korea during the period when the country was carrying out the radical institutional reforms. Table 1.3 shows the financial flows from the financial sector to the corporate sector. A remarkable trend in Korea after the

Table 1.3 External financing of the corporate sector in Korea (billion won)

\begin{tabular}{lrrrrrr}
\hline & 1996 & \multicolumn{1}{c}{1997} & \multicolumn{1}{c}{1998} & 1999 & 2000 & \multicolumn{2}{c}{2001} \\
\hline Total & 118,769 & 118,022 & 27,664 & 51,755 & 66,531 & 51,939 \\
Indirect financing & 33,231 & 43,375 & $-15,862$ & 2,198 & 11,391 & 1,185 \\
$\quad$ From banks & 16,676 & 15,184 & 259 & 15,525 & 23,348 & 3,381 \\
$\quad$ From NBFIs & 16,555 & 28,191 & $-16,550$ & $-13,267$ & $-11,997$ & $-2,377$ \\
Direct financing & 56,097 & 44,087 & 49,496 & 24,792 & 18,996 & 36,838 \\
CPs & 20,737 & 4,421 & $-11,678$ & $-16,116$ & $-1,133$ & 4,210 \\
Stocks & 12,981 & 8,974 & 13,515 & 41,137 & 20,806 & 16,504 \\
CBs & 21,213 & 27,460 & 45,907 & $-2,827$ & $-2,108$ & 11,761 \\
Foreign borrowing & 12,383 & 6,563 & $-9,809$ & 11,537 & 15,765 & 2,283 \\
Others & 17,059 & 23,997 & 3,839 & 13,228 & 20,380 & 11,633 \\
\hline
\end{tabular}

Source: BOK, Flow of Funds, various issues.

Notes

"NBFIs" are non-bank financial institutions; "CP" is corporate paper; "CB" is corporate bond;

"Others" include corporate loans, government loans and so on. 
crisis was the abrupt depletion of external funds available for the corporate sector. Even during the period of rapid economic recovery in 1999 and 2000, the external funds for the corporate sector amounted to only around half of that available in 1997, and the situation became worse in 2001.

The main culprit here was the fall in indirect financing, i.e. borrowing from financial institutions. In 1998, at the height of the crisis, financial institutions withdrew 15.8 trillion won of loans from the corporate sector. Although indirect financing slowly began to recover, its level fell far short of the pre-crisis level. The amount of external financing available in 1999, at 2.2 trillion won, was only about 5 percent of the 1997 level of 43.4 trillion won. In 2000, it was still only 26 percent (11.4 trillion won) of the 1997 level. As the economy began slowing down sharply in 2001 along with the recession in the world economy, indirect financing shrank dramatically again to 2.5 percent (1.2 trillion won) of what was available in 1997.

This continued credit crunch even after the recovery was mainly because the radical institutional transition in Korea created a vacuum in its risk-taking function. In the new institutional framework, the financial sector should have acted as the major agent to assess and take risks in loan provisions. But its capability to do so was severely constrained.

First, since financial institutions themselves were in the process of ongoing reorganization and many of them were placed under government ownership, their primary concern was to meet newly-introduced supervision standards like BIS ratios and forward-looking criteria (FLC), which generally penalize corporate lending. They had little incentive to take high risks in corporate lending in the new regulatory environment.

Second, related to the above, managers in financial institutions had little incentive to help resolve the financial problems of companies. If they let those troubled companies fail now, the failure would be considered as a result of poor lending decisions by their predecessors; whereas the managers themselves would be held responsible if the firms to which they extended new loans should fail. In this situation, they tended to underestimate the value of currently ailing firms and preferred to liquidate them rather than exert efforts to turn them around. This incentive became stronger if the assets related to the ailing firms were already classified as NPLs and therefore provisions against them had been made. ${ }^{13}$

In contrast, Malaysia did not experience such a prolonged credit crunch in the corporate sector as in Korea. One major reason why the Malaysian government introduced capital controls in September 1998 was to ease the credit crunch brought about by the financial crisis and a short experiment with the "virtual IMF regime". Contrary to its Korean counterpart, the Malaysian government eased financial regulations and encouraged financial institutions to extend loans to corporations. It also focused its policies on restructuring loans and turning around corporations, and 


\section{Institutional transition and transition cost}

"only resort[ed] to foreclosures and sale of collateral as a last resort" (Ariff et al. 2001: 79-80). In short, Malaysia attempted to overcome the financial crisis by creating a financial environment more favorable to corporate lending and helping domestic corporations survive financial troubles. As mentioned above, NPLs in the Malaysian economy also increased substantially due to financial troubles after the crisis. However, their size was much smaller than that of Korea because Malaysia maintained its risktaking mechanism and let it work.

In the above, I have attempted to compare transition costs involved in institutional transition in Korea and non-transition in Malaysia. Of course, this is no more than a rough picture and the actual size and contents of transition costs can be controversial. However, the comparison at least shows that Korea paid much higher transition costs than Malaysia. This suggests that the Korean government and the IMF neglected or underestimated transition costs involved in a radical institutional transition, whereas the Malaysian government was more concerned with transition costs in refusing to adopt the IMF program. ${ }^{14}$

\section{Conclusion}

Acknowledging and considering the existence of transition cost is disconcerting to researchers. The nature and size of transition cost differ according to the context within which an institutional transition is attempted. This therefore makes our analysis more complicated rather than simplified, and it becomes harder to draw general implications. However, this is a fact of life we have to face rather than avoid. I have argued that North's transaction cost analysis avoids this complexity by resorting to residual analysis and reductionism, and it therefore provides little help towards meaningful understanding and designing useful programs for institutional change. I have also demonstrated, with a comparison of institutional transitions in Malaysia and Korea, that it is possible for a country to pay much higher costs than expected in an institutional transition if it does not pay enough attention to possible transition costs.

When we consider future institutional changes in Southeast Asia, this aspect of transition cost should be given due consideration. We can certainly learn from existing theories and the experiences of other countries. However, if we want to derive a useful program for institutional transition for individual countries, we should go one step further. The theories and lessons from other countries should be interwoven with careful analyses of the real challenges faced by each country, the available alternatives, the costs and benefits involved in those alternatives, and so on.

The only universal lesson that we can derive from our discussion above would be that there is no panacea for institutional management and institutional change. A one-size-fits-all solution often results in huge transition costs. Reality is full of gray areas determined by the contexts in question, 
which suggests to us that there are many middle roads for institutional transition. What is important, therefore, is to find what middle roads are suitable for the countries concerned.

\section{Notes}

1 For the contents and the origin of the Washington consensus, refer to Williamson $(1993,1997)$ and Gore $(2000)$.

2 For discussions on the different stances of the institutionalists, refer to Langlois (1986: 1-25), Hodgson (1991), Matthews (1986), Boulding (1957) and Dorfman et al. (1963).

3 In this context, Khan (1995: 74) points out that "the gap between the neoclassical production function and reality can always and tautologically be attributed to transaction cost”.

4 North (1990: 86) argues as follows: "A change in relative prices leads one or both parties to an exchange, whether it is political or economic, to perceive that either or both could do better with an altered agreement or contract. An attempt will be made to renegotiate the contract ... Over time, the rule may be changed or simply be ignored and unenforced. Similarly, a custom or tradition may be gradually eroded and replaced with another."

5 For discussions on the "second-best theorem", see Bohm (1987), and Boadway and Bruce (1984: 131-136).

6 Level effects refer to once-and-for-all changes that raise or lower balanced growth paths without affecting their slope, whereas growth effects refer to changes in parameters that alter growth rates along balanced paths.

7 Refer to Freeman (1987), Lundvall (1992) and Nelson (1993).

8 See Kuisel (1981).

9 The Ayub Khan regime was a "strong state" equipped with the oppressive power comparable with its counterparts in East Asian countries like Korea or Taiwan and instituted a similar developmental strategy. However, " $[t]$ he experiment was abandoned after the uprising of 1969-71 and a civil war in which possibly a million people died" (Khan 1995: 85). For Khan, this failure was mainly due to attempting an institutional transition without fully considering costs from resistance to the proposed change. He argues that other strategies of transition would have been preferable to attempting to establish an East Asian-type developmental state.

10 For details, refer to Shin (2003).

11 For details, see Shin and Chang (2003).

12 It is not precise to compare them directly because figures for M\&A sales are reported on gross basis and those for FDI inflows are reported on net basis in World Investment Report. However, the comparison advanced here at least provides a rough picture of the relative share between $M \& A$ sales and greenfield investments in the FDI inflow of individual countries.

13 This was well reflected in creditor banks' preference of selling Daewoo Motors and Hynix to foreign buyers than turning them around with their own initiatives.

14 It should be noted that, apart from transition costs discussed here in relation to the risk-taking mechanism in the economy, Malaysia experienced far lower economic and social costs from unemployment in overcoming the crisis. Its unemployment rate only rose from 2.4 percent in 1997 to 3.2 percent in 1998 and 3.4 percent in 2000, a level regarded as a full employment rate in most countries. The average unemployment rate during the post-crisis period, 1998-2001, was 3.4 percent, only slightly higher than the pre-crisis average of 


\section{Institutional transition and transition cost}

3.1 percent during 1991-1997. By contrast, Korea experienced a larger scale of unemployment by adopting IMF's policies of retrenchment and liberal labor market. The unemployment rate in Korea, which had been 2.4 percent on average during 1991-1997, jumped sharply to 7.0 percent in 1998 and 6.3 percent in 1999 before it declined to 4.1 percent in 2000 and 3.8 percent in 2001. The average unemployment rate during the post-crisis period, 1998-2001, was 5.3 percent, more than double the pre-crisis average.

\section{References}

Ariff, M., Setapa, A. and Lin, E.Y.S. (2001) "Governance re-invented: the progress, constraints, and remaining agenda in bank and corporate restructuring in Malaysia”, in UNESCAP (United Nations Economic and Social Commission for Asia and the Pacific) Governance Re-Invented: The Progress, Constraints, and Remain ing Agenda in Bank and Corporate Restructuring in East and South-East Asia. Online. Available at: <http://www.unescap.org/drpad/publication/toc/fin\%5F2148 con.htm $>$ (accessed 24 December 2003).

Arthur, B. (1989) "Competing technologies, increasing returns, and lock-in by historical events”, Economic Journal, 99/393: 116-131.

Bank Negara Malaysia (December 2000; December 2001; December 2002) "Monthly statistical bulletin". Online. Available at: <http://www.bnm.gov.my/ index.php? $\mathrm{ch}=116 \& \mathrm{cpg}=352 \& \mathrm{ac}=4>($ accessed 24 December 2003$)$.

Bank of Korea (BOK) (1999, 2000, 2001, 2002), "Flow of funds in 1998/1999/2000/2001". Online. Available at: <http://www.bok.or.kr> (accessed 24 December 2003).

Boadway, R.W. and Bruce, N. (1984) Welfare Economics, Oxford: Blackwell.

Bohm, P. (1987) "Second best", in J. Eatwell, M. Milgate and P. Newman (eds) The New Palgrave: A Dictionary of Economics, 4, London: Macmillan.

Boulding, K.E. (1957) "A new look at institutionalism", American Economic Review, 47(2): 1-12.

Chang, H.-J. (1994) The Political Economy of Industrial Policy, London: Macmillan.

Danaharta (2000, 2001, 2002) "Operations reports: six months ended in 31 December 2000/2001/2002". Online. Available at: <http://www.danaharta. com.my $>$ (accessed 24 December 2003).

Dorfman, J., Ayers, C.E., Chamberlain, N.W., Kuznets, S. and Gordon, R.A. (1963) Institutional Economics: Veblen, Commons, and Mitchell Reconsidered, Berkeley: University of California Press.

Financial Supervisory Commission $(1999,2000,2001)$ "The current status of nonperforming loans in the financial sector at the end of 1998/1999/2000". Online. Available at: <http://www.fsc.go.kr> (accessed 24 December 2003).

- (2002) "The current status of non-performing loans in the banking sector at the end of 1998/1999/2000". Online. Available at: <http://www.fsc.go.kr> (accessed 24 December 2003).

Freeman, C. (1987) Technology Policy and Economic Performance: Lessons from Japan, London: Pinter.

Gore, C. (2000) "The rise and fall of the Washington Consensus as a paradigm for developing countries", World Development 28(5): 789-804.

Hodgson, G. (1991) "Institutional economic theory: the old versus the new", in G. Hodgson (ed.) After Marx and Sraffa: Essays in Political Economy, London: Macmillan. 
Khan, M. (1995) "State failure in weak state: a critique of new institutionalist explanations", in J. Harris, J. Hunter and C.M. Lewis (eds) The New Institutional Economics and Third World Development, London: Routledge.

Kuisel, R.F. (1981) Capitalism and the State in Modern France, Cambridge: Cambridge University Press.

Langlois, R.N. (1986) "The new institutional economics: an introductory essay", in R.N. Langlois (ed.) Economics as a Process: Essays in the New Institutional Economics, Cambridge: Cambridge University Press.

Lucas, R.E. Jr. (1988) "On the mechanics of economic development", Journal of Monetary Economics, 22(1): 3-42.

Lundvall, B.-A. (ed.) (1992) National Systems of Innovation: Towards a Theory of Innovation and Interactive Learning, London: Pinter.

Mathews, R.C.O. (1986) "The economics of institutions and the sources of economic growth", Economic Journal, 96(383): 903-918.

Nelson, R.R. (ed.) (1993) National Innovation Systems: A Comparative Analysis, Oxford: Oxford University Press.

North, D. (1981) Structure and Change in Economic History, New York: Norton.

- (1990) Institutions, Institutional Change and Economic Performance, Cambridge: Cambridge University Press.

PFOC (2000, 2001, 2002, 2003) White Paper on Management of Public Funds (in Korean), Seoul: Public Fund Oversight Committee, Ministry of Finance and Economy.

Shin, J.-S. (2003) "Economic restructuring after the financial crisis: a comparison between South Korea and Malaysia", in progress.

Shin, J.-S. and Chang, H.-J. (2003) Restructuring Korea Inc.: Financial Crisis, Corporate Reform, and Institutional Transition, London: Routledge.

UNCTAD (2003) World Investment Report 2003, New York and Geneva: United Nations.

Williamson, J. (1993) "Democracy and the 'Washington Consensus'", World Development, $21(8)$ : 329-336.

(1997) "The Washington Consensus revisited", in L. Emmerij (ed.) Economic and Social Development in XXI Century, Washington, D.C.: Inter-American Development Bank.

Williamson, O.E. (1985) The Economic Institutions of Capitalism, New York: Free Press. 


\title{
2 Educational reforms and challenges in Southeast Asia
}

\author{
Fredrik Sjöholm
}

\section{Introduction}

Education is likely to play an increasingly important role in Southeast Asia over the next few decades. The reason is that past development strategies in the region have primarily relied on exports of labor-intensive and lowskilled products, but there now seems to be a need to upgrade production and exports. Even in the more high-skilled industries, such as electronics, the part of the production process located in Southeast Asia is often simple assembly. One illustrative example is found in the hard disk drive (HDD) industry. In 1995 all major foreign firms in the industry had assembly plants in Southeast Asia and the region accounted for as much as 64 percent of final global assembly and 44 percent of total global employment (Amsden et al. 2001: 3). Still, the region only received 13 percent of the industry's wages because high-skilled activities are maintained in Europe, Japan and the US, and low-skilled activities are located in Southeast Asia.

Whereas the past development strategy of labor-intensive exports has been successful, there are reasons to believe that it may fail to provide future growth. One reason is that the past success has led a number of countries to follow the example set by Southeast Asia. Most importantly, the reliance on low-skilled production has become more problematic for Southeast Asia over the last decade when both China and India have liberalized their economies. China has even become the largest exporter of manufactures in the developing world, which intensifies the competition for ASEAN exporters. It should be emphasized that the effect from the Chinese and Indian liberalization is not symmetric across the ASEAN countries and that it also offers positive export possibilities to these growing markets. For this opportunity to be realized, it is important that the ASEAN countries manage to upgrade their production and thereby avoid competing in goods where the emerging giants can be expected to be especially competitive. ${ }^{1}$

The increased competition for the traditional exports from Southeast Asia was one, of many, determinants of the crisis starting in 1997. As seen 
in Table 2.1, all countries in ASEAN5 had average annual growth rates of exports between 13 (Indonesia) and 20 (Malaysia) percent between 1990 and 1995. The growth rate in exports declined in 1996 in all countries except the Philippines, and the decline was particularly large in Thailand, Malaysia and Singapore. The slowdown had a negative impact on economic growth in the region and also caused problems with growing current account deficits. With the exception of Singapore, all other countries had alarmingly large deficits that increased further in 1996. The deficits were one of the reasons for the reluctance of foreign creditors to roll over loans to the ASEAN countries, which contributed to the onset of the crisis (Iriana and Sjöholm 2002).

Part of the slowdown in exports was caused by an appreciation of regional currencies, which were tied to the US dollar. However, the appreciation was relatively modest, ranging from 5 percent in Indonesia and 18 percent in Singapore between 1990 and 1996, and other factors must have contributed to the slowdown in exports. Again, one such factor is the increased competition in relatively low-skilled industries, which brings us back to the need for an industrial upgrade. Such an upgrade depends upon the ability to absorb and master new technologies and on the skill of the labor force. Both of these factors are partly dependent on education. This chapter will focus on the state of education in Southeast Asia and on present reforms within this area. The chapter starts with a general overview of the educational situation and is followed by more in-depth analyses of changes and obstacles to reforms in Indonesia, Malaysia and Singapore.

Table 2.1 Exports, current account balances and exchange rates in some Southeast Asian countries.

\begin{tabular}{|c|c|c|c|c|c|c|c|c|c|}
\hline \multirow[b]{2}{*}{ Country } & \multicolumn{3}{|c|}{ Export growth } & \multicolumn{3}{|c|}{$\begin{array}{l}\text { Current account } \\
\text { deficits as a share } \\
\text { of } G D P\end{array}$} & \multicolumn{3}{|c|}{$\begin{array}{l}\text { Real effective } \\
\text { exchange rates } \\
(1990=100)\end{array}$} \\
\hline & $\begin{array}{l}\text { Average } \\
1990- \\
1995\end{array}$ & 1996 & 1997 & $\begin{array}{l}\text { Average } \\
1990 \\
1995\end{array}$ & 1996 & 1997 & 1995 & 1996 & 1997 \\
\hline Indonesia & 13 & 10 & 7 & -2 & -3 & -2 & 100 & 105 & 62 \\
\hline Thailand & 19 & -1 & 3 & -7 & -8 & -2 & 107 & 112 & 76 \\
\hline Malaysia & 20 & 6 & 1 & -6 & -5 & -5 & 102 & 108 & 85 \\
\hline Singapore & 18 & 6 & 0 & 12 & 15 & 18 & 113 & 118 & 114 \\
\hline Philippines & 15 & 17 & 23 & -4 & -5 & -5 & 110 & 117 & 90 \\
\hline
\end{tabular}

Source: International Monetary Fund (2000), International Monetary Fund (1992-1999).

Note

An increase means an appreciation of the real effective exchange rate. 
30 Educational reforms and challenges in SE Asia

\section{Educational performance in Southeast Asia}

\section{Some educational indicators}

The state of a country's education system can be evaluated from inputs into education, such as public expenditures on education and the number of teachers, and from outputs of educational efforts, such as enrollment rates and literacy rates. Starting with input measures, Table 2.2 shows figures on public expenditures on education in Southeast Asia, and in some Northeast Asian countries for the sake of comparison. The countries differ substantially in their level of economic development; the wealthiest country in Southeast Asia, Singapore, has a gross domestic product (GDP) per capita that is 20 times higher than the poorest country, Myanmar. There is a positive correlation between the level of economic development and the amount of public expenditures on education; Myanmar spends only slightly more than 1 percent of gross national product (GNP) on education whereas Singapore, Malaysia, Thailand and the Philippines spend between 3 and 5 percent, which compares well with the Northeast Asian countries. Especially, Malaysia and Thailand have a high level of spending in comparison with their level of income. The former country has been spending substantial amounts of GNP on education since at least the 1980s, whereas the latter has increased expenditures primarily in the 1990s. The Philippines has a long tradition of education-friendly policies and had for a long time perhaps the most developed educational standard in the region. Paradoxically, the head start in the provision of education has not resulted in a particularly rapid economic development in the Philippines. Furthermore, Indonesia spends only slightly more than Myanmar on education, which is substantially less than many poorer countries in the region.

The figures in Table 2.2 on the share of total public expenditures allocated to education are incomplete but suggest that countries that spend a high proportion of GNP on education also spend a high proportion of public expenditures on education. Almost one-quarter of public expenditures in Singapore goes to education but only about 8 percent in Indonesia.

Differences in the countries' demographic situations might affect how much resource is actually allocated per student. Table 2.3 shows figures on public expenditures per pupil and as a percentage of GNP per capita. In addition, the figures are divided into primary, secondary, and tertiary schooling to show which level of schooling is emphasized in the different countries. Again, the figures suggest that Malaysia and Thailand have high expenditures on education in relation to their income levels. Malaysia has especially high expenditures on tertiary schooling, which is also the case in Vietnam. Among the poorer countries, Myanmar has low expenditures per pupil but Laos and Vietnam quite high. 
Educational reforms and challenges in SE Asia

Table 2.2 Educational expenditures in Southeast Asia

\begin{tabular}{|c|c|c|c|c|c|c|c|}
\hline \multirow[t]{2}{*}{ Country } & \multirow{2}{*}{$\begin{array}{l}\text { GDP/capita } \\
\text { (PPP US \$) } \\
1999\end{array}$} & \multicolumn{3}{|c|}{$\begin{array}{l}\text { Public expenditures on } \\
\text { education as a percent of } \\
\text { GNP }\end{array}$} & \multicolumn{3}{|c|}{$\begin{array}{l}\text { Public expenditures on } \\
\text { education as a share of total } \\
\text { government expenditures }\end{array}$} \\
\hline & & 1986 & 1990 & 1996 & 1986 & 1990 & 1996 \\
\hline Singapore & 20,767 & 3.9 & 3.0 & 3.0 & 11.5 & 18.2 & 23.4 \\
\hline Malaysia & 8,209 & 6.9 & 5.5 & 5.2 & 18.8 & 18.3 & 15.4 \\
\hline Thailand & 6,132 & 3.4 & 3.6 & 4.8 & 17.9 & 20.0 & na \\
\hline Philippines & 3,805 & 2.1 & 2.9 & 3.2 & 11.2 & 10.1 & 17.6 \\
\hline Indonesia & 2,857 & 0.9 & 1 & 1.4 & 4.3 & na & 7.9 \\
\hline Vietnam & 1,860 & na & 2.1 & 2.9 & na & 7.5 & na \\
\hline Laos & 1,471 & 0.5 & 2.5 & 2.5 & 6.6 & na & 10.3 \\
\hline Cambodia & 1,361 & na & na & 2.9 & na & na & na \\
\hline Myanmar & 1,027 & 1.9 & na & 1.2 & na & na & 14.4 \\
\hline Japan & 24,898 & na & 3.6 & 3.6 & na & 10.4 & 9.9 \\
\hline Hong Kong & 22,090 & 2.5 & 2.8 & 2.9 & 19.8 & 17.4 & 17.0 \\
\hline South Korea & 15,712 & 3.8 & 3.5 & 3.7 & na & na & 17.5 \\
\hline China & 3,617 & 2.3 & 2.3 & 2.3 & 11.1 & 12.8 & 12.2 \\
\hline
\end{tabular}

Source: UNESCO (2001).

Table 2.3 Educational expenditures per pupil, 1996

\begin{tabular}{lccc}
\hline \multirow{2}{*}{ Country } & \multicolumn{3}{c}{ Current expenditures } \\
\cline { 2 - 4 } & Primary & Secondary & Tertiary \\
\hline Singapore & 7 & 12 & 31 \\
Malaysia & 10 & 17 & 85 \\
Thailand & 14 & 11 & 26 \\
Philippines & 9 & 9 & 14 \\
Indonesia & na & na & na \\
Vietnam & 7 & 9 & 89 \\
Laos & 7 & 14 & 63 \\
Cambodia & na & na & na \\
Myanmar & 3 & 9 & 19 \\
& & & \\
Japan & 17 & 19 & 14 \\
Hong Kong & 6 & 13 & 54 \\
South Korea & 17 & 13 & 6 \\
China & 6 & 12 & 67 \\
\hline
\end{tabular}

Source: UNESCO (2001).

Another input measure of obvious importance for the quality of education is the availability of teachers. Table 2.4 shows the number of teachers and the pupil-teacher ratio in primary and secondary school. The number of teachers per 1000 non-agriculture labor force is highest in 


\section{Educational reforms and challenges in SE Asia}

some of the poorer countries such as Laos, Indonesia and Vietnam. However, the figures are likely to be biased as a general measure on the stock of teachers, since a relatively large share of the population in these countries is employed in agriculture. Moreover, there might be differences between countries' shares of the population in the school ages. An alternative measure is the pupil-teacher ratio, which is shown for primary and secondary education. The ratio is very high in primary schools in the poorer countries, especially in Myanmar and Cambodia where there are almost 50 school children per teacher. Indonesia, Vietnam and Laos have lower ratios, most likely because of their relatively high shares of teachers in the labor force. Three of the countries that spend most on education, Singapore, Malaysia and Thailand, have the fewest students per teacher in primary school. The figures for secondary school are quite different with very low ratios in, for instance, Indonesia, Myanmar and Laos, and with the highest ratio in the Philippines.

The previous tables showed various inputs to education. These inputs produce an output that is also affected by the qualifications of teachers, the curriculum, the availability and number of schools, and other such factors. Whereas the quality of education is difficult to measure, we can observe basic indicators such as school enrollment rates, mean years of schooling and literacy rates. Table 2.5 shows the adult literacy rates in 1999 and the mean years of schooling between 1970 and 2000. Most Southeast Asian countries have literacy rates above the 73 percent average

Table 2.4 The availability of teachers in Southeast Asia

\begin{tabular}{|c|c|c|c|c|c|c|}
\hline & \multicolumn{2}{|c|}{$\begin{array}{l}\text { Teachers per } 1,000 \\
\text { non-agricultural } \\
\text { labor force }\end{array}$} & \multicolumn{2}{|c|}{$\begin{array}{l}\text { Primary school } \\
\text { pupil-teacher } \\
\text { ratio }\end{array}$} & \multicolumn{2}{|c|}{$\begin{array}{l}\text { Secondary school } \\
\text { pupil-teacher } \\
\text { ratio }\end{array}$} \\
\hline & 1990 & 1996 & 1990 & 1996 & 1990 & 1996 \\
\hline Singapore & 18 & 18 & 26 & 21 & 21 & 20 \\
\hline Malaysia & 41 & 41 & 20 & 19 & 19 & 19 \\
\hline Thailand & 50 & na & 22 & na & 18 & na \\
\hline Philippines & 38 & 35 & 33 & 35 & 33 & 32 \\
\hline Vietnam & 55 & 53 & 35 & 32 & 18 & 29 \\
\hline Indonesia & 65 & 56 & 23 & 22 & 13 & 14 \\
\hline Laos & 78 & 75 & 27 & 30 & 12 & 17 \\
\hline Cambodia & 53 & 42 & 33 & 46 & 15 & 18 \\
\hline Myanmar & 38 & 36 & 48 & 46 & 13 & 16 \\
\hline Japan & 25 & 26 & 21 & 19 & na & 14 \\
\hline Hong Kong & 20 & 18 & 27 & 24 & 21 & 20 \\
\hline South Korea & 25 & 23 & 36 & 31 & 26 & 25 \\
\hline China & 55 & 50 & 22 & 24 & 15 & 17 \\
\hline
\end{tabular}

Source: UNESCO (2001). 
Table 2.5 Literacy rates and mean years of schooling in Southeast Asia

\begin{tabular}{|c|c|c|c|c|c|}
\hline \multirow[t]{2}{*}{ Country } & \multirow{2}{*}{$\begin{array}{l}\text { Adult } \\
\text { literacy rate } \\
1999\end{array}$} & \multicolumn{4}{|c|}{ Mean years of schooling } \\
\hline & & 1970 & 1980 & 1990 & 2000 \\
\hline Singapore & 92.1 & 7.5 & 8.5 & 9 & 9.5 \\
\hline Malaysia & 87.0 & 6.3 & 8 & 9.2 & 9.4 \\
\hline Thailand & 95.3 & 4.1 & 4.4 & 5.6 & 6.5 \\
\hline Philippines & 95.1 & 4.8 & 6.5 & 7.3 & 8.2 \\
\hline Indonesia & 86.3 & 2.9 & 3.7 & 4.0 & 5.0 \\
\hline Vietnam & 93.1 & na & na & 3.8 & na \\
\hline Laos & 47.3 & na & na & na & na \\
\hline Cambodia & 68.2 & na & na & na & na \\
\hline Myanmar & 84.4 & 1.4 & 1.6 & 2.5 & 2.8 \\
\hline Japan & 100.0 & 7.5 & 8.5 & 9.0 & 9.5 \\
\hline Hong Kong & 93.3 & 6.3 & 8.0 & 9.2 & 9.4 \\
\hline South Korea & 97.6 & 4.9 & 7.9 & 9.9 & 10.8 \\
\hline China & 83.5 & na & 4.8 & 5.9 & 6.4 \\
\hline $\begin{array}{l}\text { Developing countries } \\
\text { (average) }\end{array}$ & 72.9 & na & 3.9 & 4.9 & na \\
\hline OECD (average) & 100.0 & 7.3 & 8.6 & 9.1 & 9.6 \\
\hline
\end{tabular}

Source: UNDP (2001).

in developing countries. The exceptions are Laos and Cambodia. The situation in Laos is particularly troublesome with a literacy rate of only 47 percent, which is very low also in an international comparison. The literacy rate is above 90 percent in Singapore, Thailand, the Philippines and Vietnam. This is a rather strong achievement, especially in the latter two relatively poor countries. On the other hand, the literacy rate in Singapore is less than in other countries on a similar income level. For instance, the OECD has a 100 percent literacy rate despite an average income similar to Singapore's.

All countries have seen a relatively large increase in the mean years of schooling between 1970 and 2000, but there are big differences among the countries. For instance, Vietnam, Indonesia and Myanmar all had fewer years of schooling than the average among developing countries; this is probably true also for Laos and Cambodia, for which figures are not available. The population of Myanmar has particularly few years of schooling; the median figure is less than three years in 2000. On the other hand, Malaysians seem to spend many years in school, about the same number as their wealthier neighbors in Singapore and at an average OECD level.

The mean years of schooling is related to the school enrollment ratios, which are shown in Table 2.6. Almost 100 percent enrollment in primary school was achieved by 1990 in all of the included countries. The figures for Malaysia and Singapore are affected by the possibility of teaching the 
34 Educational reforms and challenges in SE Asia

Table 2.6 School enrollment ratios in Southeast Asia

\begin{tabular}{|c|c|c|c|c|c|c|}
\hline \multirow[t]{2}{*}{ Countries } & \multicolumn{2}{|c|}{$\begin{array}{l}\text { Primary school } \\
\text { gross enrollment rate } \\
(\%)\end{array}$} & \multicolumn{2}{|c|}{$\begin{array}{l}\text { Secondary school } \\
\text { gross enrollment rate } \\
(\%)\end{array}$} & \multicolumn{2}{|c|}{$\begin{array}{l}\text { Tertiary school } \\
\text { gross enrollment rate } \\
(\%)\end{array}$} \\
\hline & 1990 & 1996 & 1990 & 1996 & 1990 & 1996 \\
\hline Singapore & 104 & 94 & 68 & 74 & 19 & 38 \\
\hline Malaysia & 94 & 101 & 56 & 64 & 7 & 12 \\
\hline Thailand & 99 & 87 & 30 & 56 & na & 22 \\
\hline Philippines & 111 & 114 & 73 & 77 & 28 & 29 \\
\hline Indonesia & 115 & 113 & 44 & 51 & 9 & 11 \\
\hline Vietnam & 103 & 113 & 32 & 47 & 2 & 7 \\
\hline Laos & 105 & 112 & 25 & 28 & na & 3 \\
\hline Cambodia & 121 & 110 & 32 & 24 & 1 & 1 \\
\hline Myanmar & 106 & 121 & 23 & 30 & 4 & 5 \\
\hline Japan & 100 & 101 & 97 & 103 & 30 & 40 \\
\hline Hong Kong & 102 & 94 & 80 & 73 & 19 & na \\
\hline South Korea & 105 & 94 & 90 & 102 & 39 & 68 \\
\hline China & 125 & 123 & 49 & 70 & 3 & 6 \\
\hline
\end{tabular}

Source: UNESCO (2001).

children at home; in other words, whereas primary school education is compulsory in these countries, attendance in a school is not. The figures for secondary and tertiary education show much larger differences. For instance, Malaysia, Singapore and the Philippines have secondary enrollment rates above 60 percent, whereas the rates in Laos, Cambodia and Myanmar are only 30 percent or less. Interestingly, the enrollment rate in Cambodia has actually declined for both primary and secondary education between 1990 and 1996. Tertiary education shows low enrollment rates in the poorer countries but also surprisingly low in Malaysia. Singapore, the Philippines and Thailand have rather high tertiary enrollment rates although lower than in Japan and South Korea.

Not only tertiary school enrollment rates differ between the Southeast Asian countries, but also the structure of higher education. Table 2.7 shows the percentage of students in four different fields of higher education. The main difference is between a country such as Singapore, which has a large proportion of the students in the sciences and engineering faculties, and Thailand, where most tertiary students can be found within law and the social sciences. The large share of Singaporean students in engineering is the result of a deliberate policy that goes back to the early years after independence in 1965. The government was worried about widespread unemployment of white-collar workers if higher education was generally expanded rather than closely directed to the skills demanded by the foreign multinational companies. The focus became, and has 
Table 2.7 Distribution of tertiary students over field of study in Southeast Asia, in percentage of students by field of study, 1996

\begin{tabular}{|c|c|c|c|c|c|}
\hline Countries & Education & Humanities & $\begin{array}{l}\text { Law and } \\
\text { social } \\
\text { sciences }\end{array}$ & $\begin{array}{l}\text { Natural } \\
\text { sciences, } \\
\text { engineering } \\
\text { and } \\
\text { agricultural }\end{array}$ & $\begin{array}{l}\text { Medical } \\
\text { sciences }\end{array}$ \\
\hline Singapore & 7 & 33 & in Humanities & 58 & 3 \\
\hline Malaysia & na & na & na & na & na \\
\hline Thailand & 9 & 4 & 60 & 21 & 6 \\
\hline Philippines & 15 & 6 & 31 & 28 & 19 \\
\hline Indonesia & 17 & 6 & 46 & 28 & 2 \\
\hline Vietnam & na & na & na & na & na \\
\hline Laos & 28 & 7 & 13 & 38 & 11 \\
\hline Myanmar & 0 & 42 & 22 & 37 & na \\
\hline Cambodia & 26 & 2 & 29 & 23 & 20 \\
\hline Japan & 8 & 56 & in Humanities & 23 & 8 \\
\hline Hong Kong & 9 & 9 & 34 & 42 & 4 \\
\hline South Korea & 6 & 17 & 25 & 34 & 5 \\
\hline China & 16 & 6 & 9 & 53 & 9 \\
\hline
\end{tabular}

Source: UNESCO (2001).

Note

Law and social sciences are included under the humanities in Singapore and Japan.

remained, to supply skilled technicians and engineers, whereas higher education in arts and social sciences has been deliberately restricted.

We have seen a number of educational indicators and the overall picture suggests that the differences are large within the region and that rich countries put more emphasis on education than poor countries do. Still, there are variations also between countries on a similar income level. One way to summarize the educational standard in the countries is to use an index by the UNDP (2001: 240). The index in Table 2.8 is based on school enrollment rates and literacy rates and should, because of its limited number of criteria, be interpreted with caution. The higher the value on the index, the better the country performs in the area of education. The index shows that the Philippines actually performs best, followed by Singapore, Thailand and Vietnam. Laos and Cambodia have lower values on the index than the average among developing countries.

\section{A more detailed discussion}

It has been widely argued that all the high performing Asian economies shared a strong emphasis on education and skill upgrading (World Bank 1993, Campos and Root 1996). As seen from the discussion above, this is, 
Educational reforms and challenges in SE Asia

Table 2.8 Income per capita in Southeast Asia and UNDP's education index, 1999

\begin{tabular}{lcl}
\hline & $\begin{array}{l}\text { GDP per capita } \\
(1999, \text { PPP US } \$)\end{array}$ & $\begin{array}{l}\text { UNDP's } \\
\text { education index }\end{array}$ \\
\hline Singapore & 20,767 & 0.87 \\
Malaysia & 8,209 & 0.80 \\
Thailand & 6,132 & 0.84 \\
Philippines & 3,805 & 0.91 \\
Indonesia & 2,857 & 0.79 \\
Vietnam & 1,860 & 0.84 \\
Laos & 1,471 & 0.51 \\
Cambodia & 1,361 & 0.66 \\
Myanmar & 1,027 & 0.75 \\
& & \\
Japan & 24,898 & 0.93 \\
Hong Kong & 22,090 & 0.83 \\
South Korea & 15,712 & 0.95 \\
China & 3,617 & 0.80 \\
Developing countries & 3,530 & 0.69 \\
OECD & 22,020 & 0.94 \\
\hline
\end{tabular}

Source: UNDP (2001).

in fact, not typically the case for Southeast Asia. On the contrary, Ann Booth has convincingly showed that Southeast Asia has traditionally been neglecting education rather than promoting it (Booth 1999a, 1999b). Taking all of the different measures on education into account, it seems clear that there is one group of countries which performs reasonably well in promoting education. This group includes Singapore, Malaysia, Thailand, the Philippines and perhaps also Vietnam. There is also a group of Southeast Asian countries where educational standards seems low. This group includes Laos, Cambodia, Myanmar and perhaps Indonesia. Moreover, even among the countries that do relatively well according to the discussed figures, a more detailed look reveals various problems and shortcomings.

For instance, Singapore might be the best educational achiever in Southeast Asia, but it still lags behind Northeast Asia and the OECD despite having a similar or even higher income level. The reason is that the official emphasis on human resource development has only in recent years been matched by actual improvements in education. As late as 1997, almost 25 percent of the labor force had, at most, only a primary education (Booth 1999a: 296). The lack of appropriate skills in the local labor force has forced Singapore to rely on a large number of foreigners to achieve the necessary upgrading of production.

Thailand and Malaysia are two other countries that seem to perform reasonably well in supporting education, but these countries also suffer from various problems. The standard of education in Thailand was for a 
long time the worst in the region. Access to higher education was limited and even provision of basic education was arbitrary in the rural areas. The neglect of education created bottlenecks that in the late 1980s seemed to threaten the country's continued economic development. As a result, the government introduced a compulsory nine-year schooling and increased expenditures on education. The expansion of secondary education, in particular, was rapid with the enrollment rate in lower secondary education increasing from about 32 percent in 1987 to 66 percent in 1996 and in upper secondary education from about 24 percent to about 40 percent, according to Booth (1999a). Still, large problems remain, such as the low number and poor quality of science and technology students (Brimble 2001). As seen in Table 2.7, there are few students studying natural sciences or engineering. As a result, Thailand only had 119 engineers and scientists per million population before the crisis, compared to, for instance, 350 in China. A combination of an archaic university system, low salaries for teachers and insufficient funds from the government caused the poor quality of higher education. The low salaries, in particular, led to the low qualifications of university teachers in science and engineering; only about 55 percent of these teachers have a master's degree and 27 percent a $\mathrm{PhD}$.

Malaysia has traditionally been spending more on education than other countries in the region, at least in relation to its level of development. One reason is the effort to stimulate the ethnic Malays to continue in higher education, and thereby to diminish the large income differences between different ethnic groups. One cannot, however, escape the impression that Malaysia has not received sufficient economic returns on its large investment in education. One reason is that some of Thailand's problems seem to be present also in Malaysia. Employers complain about the difficulties in finding skilled workers (Rajah 2003). The reason seems to be that although education has been expanded, an insufficient share has been allocated to science and engineering. Malaysia has only about 2 percent of secondary students in technical education compared to, for instance, 19 percent in Korea and 12 percent in Indonesia. This lack of skilled employees has been one major problem for upgrading production and has led to difficulties for "high-tech" projects such as the Multimedia Super Corridor outside of Kuala Lumpur.

The relative poor performance of Indonesia may come as a surprise since Indonesia has often been singled out as a successful example of how developing countries can achieve widespread improvement in the provision of basic education. The Indonesian reputation stems from the dramatic expansion of education that started after the large increases in oil revenues in the 1970s. More than 60,000 new schools were built, real expenditures spent on education more than doubled, primary education was made compulsory and school fees were abolished (Duflo 2000). As a result, a near 100 percent enrollment ratio was achieved in primary education by the 1980s, and 


\section{Educational reforms and challenges in SE Asia}

secondary school enrollment increased from 35 to 48 percent for male students and from 23 to 39 percent for female students between 1980 and 1993 (Thee 1998: 121). However, as seen from the discussion above, this initial achievement has not been matched by the provision of higher education or by improvement to the quality, and not only the quantity, of basic education. The government's expenditure on education is lower than in almost all neighboring countries. Moreover, the quality at all levels of education remains poor. ${ }^{2}$ For instance, 9-10-year-old Indonesian school children perform below the international average in comparative tests (World Bank 1997: 120). Moreover, most university graduates in Indonesia require months of extensive on-the-job training before they can contribute to production (Booth 1999a: 301). There are additional problems with tertiary education. For instance, the tertiary system seems to emphasize relatively cheap education rather than be guided by the economy's need for people trained in science and engineering. This has resulted not only in a weak skill base, but also in high rates of unemployment among university graduates. In addition, the 44 state universities, 24 state polytechnics, and 5 state fine arts academies have been far from successful in meeting the demand for higher education (Mukhopadhaya 2001). Instead, more than a thousand private institutes have been established to meet this demand, but the minimal monitoring of their activities has resulted in widespread quality problems.

\section{Reforms, progress and obstacles}

To sum up the previous discussion, the standard of education in Southeast Asia differs between countries, but there seems to be a widespread need for reforms and improvements. Most countries in the region have recognized this need and various initiatives have been launched to improve the situation. We will look closer at some of these attempts, and also some of the obstacles, in three countries, Singapore, Malaysia and Indonesia.

\section{Singapore}

Singapore has had an exceptionally high economic growth over the last 30 years. Large investments, rapid growth of the labor force and large inflows of foreign multinational companies (MNCs) contributed to the high growth. However, politicians and policy makers seem to agree that Singapore needs to upgrade its production, increase technological innovation, and enhance creativity and entrepreneurship to secure future growth. The reasons are twofold. Firstly, growth through factor accumulation will be difficult to maintain with an investment rate that is already about 50 percent of GDP, and with an aging population. Instead, future growth has to rely more on technological progress. ${ }^{3}$ Secondly, the large reliance on foreign firms might also be difficult to maintain since the competition for 
inward FDI has increased substantially during the last decade. One indication is that inflow of FDI to Singapore decreased from 15.2 percent of GDP in 1980 to 8.2 percent in 1999 and the decrease seems to continue (UNDP 2001). Hence, a greater reliance on domestically owned firms is necessary. The Singaporean government is addressing both concerns and both have bearings on the educational system. More specifically, the government is attempting to encourage creativity, risk-taking and entrepreneurship through educational reforms.

Creativity is to be encouraged through a new curriculum that encourages critical thinking and discussions rather than memorization. All levels of education are said to face this change of focus, but the exact nature of the changes is still not clearly defined. Suggestions include a broader set of criteria for university entrance than only grades from the A-level exam. However, there are also clear signals that many of the present characteristics of Singapore's education will remain unchanged. The most important part is the early streaming process of school children into different educational programs. This takes place continuously and starts after primary three when a small number of the highest achieving students are invited to a special program. ${ }^{4}$ The streaming continues after primary four when the remaining students are divided into three different groups according to their academic capability. The outcome of the streaming is important for the children since it is difficult to get back to the "fast track" or the "main stream" once you have been found suitable for the "slow track". The next streaming occurs with the public exam after primary six. The result of the public exam determines which secondary school the children can attend, which is often said to be of importance for their future careers. The importance of streaming has encouraged students to study very hard. For instance, children of age 10-12 years spend about 3 hours a day studying after school, and 70 percent of them receive extra tuition. ${ }^{5}$ Moreover, parents frequently take several weeks or even months off from their jobs in order to prepare their children for the more important exams. The positive aspects of the system are clear from international comparisons of school children's knowledge of mathematics and science where Singaporean children are always among the best performers. However, it has frequently been argued that the system might not encourage creativity since students are too focused on preparing for exams rather than developing their own interests, reflecting upon their knowledge, or taking part in activities outside of school. To develop a system that encourages creativity without sacrificing the high average standard is not easy, but it might be desirable to at least postpone the streaming until a later age, which would take some of the pressure off the youngest children.

There is also much discussion about how to "educate for entrepreneurship" in Singapore. So far, there have been few specific policies, but initiatives include the possibility for university students to spend time in 
foreign high-tech centers, such as Silicon Valley, and programs in technopreneurship. One crucial issue is whether it is possible to teach students to become entrepreneurs. A core element of entrepreneurship is risk-taking, which is not present in the government-sponsored visits to foreign centers of excellence.

Other factors than education are presumably more important for developing creativity and entrepreneurship in Singapore. For instance, Singapore lags behind many other East Asian countries in the pace of political liberalization. Whereas countries such as Korea, Taiwan, the Philippines and Indonesia have achieved or been moving towards democracy in recent years, Singapore still limits the freedom of media, cultural expression, civil society, trade unions and political activities. This has resulted in a society where people are said to be cautious about expressing their own ideas and views and where most people opt for the safe strategy of following officially sanctioned paths. ${ }^{6}$ A society that oppresses alternative views obviously does not encourage independent thinking and creativity. It is also uncertain if the government seriously expects people to think independently and to be creative in some selected areas such as in science or business, without allowing them to express independent views on, for instance, politics.

Entrepreneurship also depends on factors other than education. For instance, the economic literature stresses the importance of incentives in the formation of a strong entrepreneurial community (Baumol 1990, Murphy et al. 1991). People will allocate their talent where the returns are the highest. Depending on the institutional setting, the returns could be highest in, for instance, entrepreneurial activities or in the government sector. The latter seems to be the case in Singapore. The Singaporean government and public bureaucracy pay high wages, among the highest in the world. In addition, the government, the public sector and the government-linked companies are closely connected. People move frequently between these three sectors, which enlarge the possible career path for people in the government sphere (Hamilton-Hart 2000).

The government has explicitly stated that the reason for the high government wages is to attract the most talented Singaporeans. The policy has provided a highly skilled and efficient bureaucracy that has allowed the country's economy to catch up quickly to the developed world. However, it is uncertain if the most talented people will continue to be of best use in the government sector at a time when Singapore has to rely on domestic innovations and entrepreneurship. Increased entrepreneurship is likely to require changes to the relative rewards of joining the public sector versus setting up own businesses. However, the government may not be too willing to lower its own relative rewards.

A final and related issue is that many of the brightest Singaporean students are financing their university studies through bonded government scholarships. These scholarships are distributed by various government 
ministries and require the students to serve with the ministry for a period of about five years after graduation. Again, it is doubtful whether the brightest students are put to best use by being employed in the government rather than in the private sector. The scholarships have recently been hotly debated in Singapore since many scholarship holders feel unhappy with the bond. However, the government has made it clear that the bond will remain.

\section{Malaysia}

Malaysia witnessed racial riots in 1969 when an election weakened the ethnic Malays' hold on power. As a result of the riots, the government launched an economic program to favor ethnic Malays - the bumiputera policies. ${ }^{7}$ These policies aimed at decreased economic inequality between different ethnic groups by favoring the bumiputeras' access to jobs in the civil administration, by forcing firms to form joint-ventures with bumiputeras, and by setting up special government agencies and financial institutions that served bumiputera interests. One consequence of the policies was that the traditional capitalists in Malaysia, the ethnic Chinese, became reluctant to make long-term investments. Instead, Malaysia had to rely on increased amounts of FDI (Drabble 2000). The FDI contributed significantly to production and exports of manufactures but, as previously mentioned, they tended to be in labor-intensive and low-skilled industries and there has been little upgrading over time. As a result, Malaysia relies today on large inflows of foreign workers to maintain the labor-intensive production. Moreover, competition from low-cost producers such as China is increasing rapidly and there are frequent reports on how foreign electronic firms are closing down their plants in Penang and instead expanding their activities in China.

To upgrade production requires, among other things, improved education of the workforce, which is directly affected by the bumiputera policies. University admissions are on the basis of ethnic background and the bumiputeras are typically granted about 55 percent of the total admissions quota. This admissions policy seems successful in improving access to education for the traditionally low-income groups; however, it discriminates against the ethnic Chinese students who are usually the best performers with the highest grades. Some estimates claim that as little as 10 percent of the intake would go to bumiputeras if there were no quotas. ${ }^{8}$ As a result of these quotas, a large number of ethnic Chinese students are not allowed into Malaysian tertiary education despite having higher grades than their bumiputera classmates. Many ethnic Chinese students go abroad to study and work, which has contributed to a brain-drain from Malaysia. The problem of losing talented students is a major concern for the government and there are, from time to time, government attempts to lure the overseas Malaysians back home, but these attempts have not been very 
successful. In addition, the easy access to university for bumiputeras has presumably made them exert too little effort on their studies, resulting in a relatively low standard of university graduates.

Former Prime Minister Mahathir made frequent threats to abolish the quota system. He argued that the bumiputeras were misusing their favored situation and therefore do not deserve to be sheltered. It seems that the present government is also concerned about the situation, but it is unlikely that the quota system will be changed. The reason is the political threat from the ethnic Malay-based Parti Islam SeMalaysia (PAS). PAS has in recent years acquired a large part of the bumiputera electorate that used to support the United Malays' National Organisation (UMNO), the main party in the coalition government. PAS has gained support by advocating a more Islamic governance of Malaysia, and PAS also strongly supports a continuation of the bumiputera polices. Hence, to abandon the bumiputera policies means that UMNO would further weaken its own political power base.

The increased Islamic consciousness among the bumiputeras has had an additional effect on Malaysia's educational system. An increasing number of children are joining Islamic schools rather than secularized ones. These schools place a greater emphasis on religious studies, including memorization of parts from the Koran. It is also said that this focus has partly been at the expense of other subjects. As a consequence, only about 25 percent of the students from Malaysia's religious schools qualify for university. ${ }^{9}$ This has led to a situation where many universities are not able to fill their bumiputera quota but they are still not allowed to increase the quota for other ethnic groups. Hence, the universities are operating below their capacities, explaining part of the low tertiary enrollment rate shown in Table 2.6. ${ }^{10}$ The present popularity with religious schooling is therefore likely to have a negative effect on the populations' skill in areas such as science, languages and mathematics. Needless to say, it is these types of skills, rather than religious training, that are typically required in industrial upgrading.

An additional but related problem is that unemployment seems to be on the rise among bumiputera university graduates. For instance, the National Economic Action Council recently reported that 44,000 Malaysian recent university graduates were unemployed. Ninety-four percent of them were bumiputeras and most had studied arts and Islamic studies. A large group of ethnic Malays attend Middle Eastern universities for religious studies, and these graduates also face great difficulties in getting work once they return to Malaysia. For instance, 1,200 Malay graduates from the Middle East have been unable to find jobs after returning to the state of Kelantan in 2002. ${ }^{11}$ 


\section{Indonesia}

As previously stated, Indonesia managed to expand its basic education rapidly in the 1970 s and the enrollment in primary school increased from only about 60 percent in the early 1970s to almost 100 percent in the late 1980s. Secondary school enrollment rates also increased accordingly. However, education in Indonesia is still plagued by various problems. For instance, even if almost all Indonesians enter primary school, there are still some 30 percent who never finish it. Hence, the dropout rate is high and there are also widespread quality problems. Most of these problems are due to poor financing; Indonesia spends less than two percent of its GNP on education (Table 2.2). Consequently, teachers' salaries are low, classes are large, books are of poor quality and 20 percent of all school buildings are in a deteriorating state (Jones and Hagul 2001).

Because of the economic crisis, public spending on education is not likely to increase. In fact, the economic problems in Indonesia will presumably lead to less public expenditure on education since the government is starved of resources and spends about one-third of its total revenues on servicing an exploding foreign debt. In addition, the reconstruction of the Indonesian financial sector requires massive amounts of government funding. It has been estimated that the reconstruction will cost the government close to 100 percent of GDP spread out over several years, which will leave few resources for educational improvements (Harianto 2000). It should also be noted that the slow privatization process suggests that the government will receive fewer revenues than previously expected. The financial constraints will delay any educational reforms; one specific example is the decision to postpone the goal of increasing compulsory education to nine years.

Declining household incomes following the crisis aggravate the problem. Many families have difficulties in meeting informal school and exam fees, and costs for books and school uniforms. In view of these unfavorable conditions, it was widely anticipated after the crisis in 1997 that dropouts from schools would increase sharply. Fortunately, the dropout rate has been lower than expected, partly due to deliberate efforts by the World Bank and the Indonesian government to reach out with educational scholarships to the poorest households (Jones and Hagul 2001). Still, there might be a delayed impact since many schools are facing grave economic difficulties. More specifically, the schools have faced a 30 percent decrease in real income and the situation is particularly difficult for private schools that depend heavily on school fees. It is therefore likely that school fees will be raised, putting additional stress on families' ability to send their children to school.

The second major factor to affect Indonesian education is the political decentralization of the country. Indonesia under President Suharto was one of the most centralized countries in the world with more than 90 


\section{Educational reforms and challenges in SE Asia}

percent of public revenues and expenditures going through the central authorities in Jakarta. The resources were distributed to the provinces from Jakarta through the Inpres program. ${ }^{12}$ The fall of Suharto in 1998 saw the emergence of strong demands for more regional independence. As a consequence, two laws of regional independence were implemented in 2001, giving the districts substantially more discretion over public income and expenditure. ${ }^{13}$ The immediate result is that the central government transferred more than 30 percent of domestic revenues back to the provinces in 2001. On the other hand, the districts will now have full responsibility for public service, including the provision of education to its citizens.

The Indonesian school system was very centralized. Teachers were central government employees, and their placement was determined by the center. The decisions to build schools and the specification of curricula were also tasks for the central authorities in Jakarta (OeyGardiner 2000). There are some advantages to decentralizing the educational system. For instance, it will allow schools to adapt their teaching according to their own strengths and abilities, and competition between schools might improve the quality of education.

There are also grounds for concern with the recent political decentralization, however. The reform will clearly benefit a few resource-rich provinces, mainly East Kalimantan, Papua, Aceh and Riau. Java is also likely to benefit since tax revenues are concentrated to Java in general (85 percent of total tax revenues) and Jakarta in particular (65 percent) ${ }^{14}$ In contrast, most provinces and districts will face diminished incomes and difficulties in meeting the new functions that have been delegated to them (Brown 1999). As an example of how the reforms affect different regions, resource-rich East Kalimantan with a population of 2.5 million people received about 140 billion rupiah from Jakarta in 2001, whereas resource-poor Yogyakarta with 1 million more inhabitants got only 1 million rupiah.

Hence, most parts of Indonesia will face falling revenues with the abolishment of the Inpres program (Sjöholm 2002). It is likely that falling revenues will have a negative effect on the poorer districts' ability to maintain the educational standard, and it is unlikely that they will be able to make much needed improvements.

\section{Conclusion}

Education is widely considered to be a key element in the economic development and growth of a country. ${ }^{15}$ At an initial development level, the requirement is to provide basic education and achieve widespread literacy. As development progresses, the requirements will shift towards improving the quality of basic education and expanding higher education. It seems that the need for educational improvements in Southeast Asia has acceler- 
ated because of the increased competition in low-skilled production and export, which has traditionally been the region's engine of growth. Hence, good education is likely to be of great importance if Southeast Asia is to continue its past rapid economic development.

The educational standard differs substantially between countries in the region but it seems fair to say that education has not been as much emphasized as in the Northeast Asian countries of Japan, South Korea and Taiwan. There is a clear positive correlation between the income level and the quality of education; countries in Southeast Asia with a high income level tend to spend more on education, have higher enrollment rates and lower student-teacher ratios, than countries on a lower income level. However, there are exceptions; the most notable are perhaps the Philippines and Vietnam that seem to have an educational standard that is better than what is indicated by the countries' low income levels. It is also worth noting that Singapore, the wealthiest country in the region with the most developed educational system, still lags behind developed countries in other parts of the world in terms of education. The countries in Southeast Asia can be divided into two groups according to their standards of education: those who have a reasonably high standard of education, namely Singapore, Malaysia, Thailand, the Philippines and Vietnam; and those who have a low standard of education, such as Myanmar, Cambodia, Laos and Indonesia.

We continued with a more detailed look at educational reforms and obstacles in Singapore, Malaysia and Indonesia. There is a widespread concern in all three countries that educational reforms are needed to achieve or sustain economic development. Singapore is trying to spur creativity and entrepreneurship and is addressing these issues by changes in the area of education. So far, there has been more talk about needed changes than actual implementations of educational reforms. Moreover, it seems that there are areas outside of education that are more directly related to entrepreneurship and creative thinking, but these areas might, for political reasons, be more difficult to address.

Malaysia has been emphasizing education throughout the last decades but it seems that the country has not achieved sufficient economic returns on its large educational investments. One reason is the serious constraint from the bumiputera policies that effectively close the door to higher education for many Malaysians. There are frequent threats of abolishing the bumiputera quotas, but it seems likely that this will be politically difficult for a government that depends on the support from the ethnic Malays.

The main constraint on educational reforms in Indonesia seems to be financial. The widespread expansion of basic education in Indonesia in the 1970s has not been followed by a similar expansion of higher education or by an improved quality of the education. Such reforms will be difficult to pursue within the near future since the government lacks the resources for costly reforms. Moreover, the political decentralization of 


\section{Educational reforms and challenges in SE Asia}

Indonesia will probably have positive effects on education in some areas of the archipelago, but it also means that most districts will have substantially less resources to spend on education.

\section{Notes}

1 One interesting characteristic of China's entry into the world economy is that the country has turned out to be a competitive producer and exporter of not only labor-intensive goods but also of more skill-intensive ones. Still, it seems likely that the main competitive edge of China will continue to be laborintensive and relatively low-skilled products, at least in the near future.

2 See Hill and Thee (1998), Lall (1998), Thee (1998) and Booth (1999a).

3 See Young (1992, 1995).

4 Singaporean children start primary one at the age of six.

5 The Straits Times 24 February 2001.

6 See for instance Cherian (2000) and Gomez (2000).

7 Bumiputera refers to ethnic Malays.

8 The Straits Times 5 May 2001.

9 The Straits Times 18 April 2001.

10 There are some signs that the science and engineering departments are quietly abandoning the quota system in order to fill the courses. This is not officially sanctioned but might have implicit support from the government.

11 The Straits Times 23 April 2002.

12 "Instruksi Presiden" (Presidential Instruction) was a program that transferred resources from wealthier regions to poorer regions in Indonesia. The program seems to have decreased regional income differences in Indonesia (Hill 1997).

13 Law no. 22/99 on local government, and law no. 25/99 on fiscal relations between the center and regions.

14 See Brodjonegoro and Asanuma (2000).

15 However, not everyone agrees. See, for example, Easterly (2001) who argues that there is no strong causality between education and economic growth.

\section{References}

Amsden, A.H., Tschang, T. and Goto, A. (2001) "Do foreign companies conduct R\&D in developing countries?”, ADB Institute Working Paper No. 14, Tokyo: Asian Development Bank Institute.

Baumol, W.J. (1990) "Entrepreneurship: productive, unproductive, and destructive", Journal of Political Economy, 97: 893-921.

Booth, A. (1999a) "Education and economic development in Southeast Asia: myths and realities", ASEAN Economic Bulletin, 16(3): 290-306.

— (1999b) "Initial conditions and miraculous growth: why is South East Asia different from Taiwan and South Korea?”, World Development, 27(2): 301-322.

- (2000) "The impact of the Indonesian crisis on welfare: what do we know two years on?", in C. Manning and P. Van Diermen (eds) Indonesia in Transition: Social Aspects of Reformasi and Crisis, Singapore: Institute of Southeast Asian Studies.

Brimble, P. (2001) "Competitiveness, FDI and technological activity enhancing the synergies in Thailand", in S. Lall and S. Urata (eds) Technology in East Asia, manuscript, The World Bank. 
Brodjonegoro, B. and Asanuma, S. (2000) "Regional autonomy and fiscal decentralization in democratic Indonesia", Paper presented at the 2nd IRSA conference, Jakarta, Indonesia, February.

Campos, J.E. and Root, H.J. (1996) The Key to the Asian Miracle: Making Shared Growth Credible, Washington, D.C.: Brookings Institution.

Cherian, G. (2000) Singapore the Air-Conditioned Nation, Singapore: Landmark Books.

Drabble, J.H. (2000) An Economic History of Malaysia, c.1800-1990: the transition to modern economic growth, London, Macmillan.

Duflo, E. (2000) "Schooling and labor market consequences of school construction in Indonesia: evidence from an unusual policy experiment", NBER Working Paper No. 7860, National Bureau of Economic Research.

Easterly, W. (2001) The Elusive Quest for Growth: Economists' Adventures and Misadventures in the Tropics, Cambridge, MA: MIT Press.

Gomez, J. (2000) Self-Censorship, Singapore's Shame, Singapore: Think Centre.

Hamilton-Hart, N. (2000) "The Singapore state revisited", The Pacific Review, 13: 195-216.

Harianto, F. (2000) "A skeleton of bank restructuring in Indonesia", paper presented at the conference Forum on Indonesia - The First 100 Days of President Abdurrahman Wahid: An Economic Agenda, Singapore, January 2000.

Hill, H. (1997) "Regional development in Southeast Asia: The challenge of subnational diversity", Journal of the Asia Pacific Economy, 2: 261-302.

Hill, H. and Thee, K.W. (eds) (1998) Indonesia's Technological Challenge, Singapore: Institute of Southeast Asian Studies.

Iriana, R. and Sjöholm, F. (2002) "Indonesia's economic crisis: contagion and fundamentals", The Developing Economies, 40: 135-151.

IMF (2000) International Financial Statistics, Washington, D.C.: International Monetary Fund.

_ (1992-1999) Direction of Trade Statistics Yearbook, Washington, D.C.: International Monetary Fund.

Jones, G.W. and Hagul, P. (2001) "Schooling in Indonesia: crisis-related and longer-term issues”, Bulletin of Indonesian Economic Studies, 37: 207-231.

Lall, S. (1998) "Technology policies in Indonesia”, in H. Hill and K.W. Thee (eds) Indonesia's Technological Challenge, Singapore: Institute of Southeast Asian Studies.

Mukhopadhaya, P. (2001) "Distribution of income and expansion of education in some East Asian countries", Journal of Interdisciplinary Economics, 10: 327-357.

Murphy, K.M., Shleifer, A. and Vishny, R.W. (1991) "The allocation of talent: implications for growth", Quarterly Journal of Economics, 106: 503-530.

Oey-Gardiner, M. (2000) "Schooling in a decentralized Indonesia", Bulletin of Indonesian Economic Studies, 36: 127-134.

Rajah, R. (2003) "Industrial technology transition in Malaysia", in S. Lall and S. Urata (eds) Competitiveness, FDI and Technological Activity in East Asia, London: Edward Elgar.

Sjöholm, F. (2002) "The challenge of combining FDI and regional development in Indonesia”, Journal of Contemporary Asia, 32: 381-393.

Thee, K.W. (1998) "Determinants of Indonesia's industrial technology development”, in H. Hill, and K.W. Thee (eds) Indonesia's Technological Challenge, Singapore: Institute of Southeast Asian Studies. 


\section{Educational reforms and challenges in SE Asia}

UNDP (2001) Human Development Report 2001, Oxford: Oxford University Press.

UNESCO (2001) Educational Statistics. Online. Available at: <www.unescostat. unesco.org/statsen/statistics/> (accessed 24 September 2001).

World Bank (1993) The East Asian Miracle: Economic Growth and Public Policy, Washington, D.C.: The World Bank.

(1997) "Training and the labor market in Indonesia: productivity gains and employment growth", Report No. 16990-IND, Washington, D.C.: The World Bank.

Young, A. (1992) "A tale of two cities: factor accumulation and technical change in Hong Kong and Singapore", NBER Macroeconomic Annual.

(1995) "The tyranny of numbers: confronting the statistical realities of the East Asian growth experience”, Quarterly Journal of Economics, 110: 641-680. 


\title{
3 Technological governance in ASEAN - failings in technology transfer and domestic research
}

\author{
Jon Sigurdson and Krystyna Palonka
}

\section{Introduction ${ }^{1}$}

Southeast Asia has been improving its international position as a base for manufacturing plants producing electrical machinery and electronics and many countries in the region have specialized in specific fields of business. In Singapore, the region's high-tech leader, engineers are abundant, and the country has successfully attracted foreign makers of semiconductors and liquid-crystal displays. Malaysia follows Singapore, centering on the audiovisual field, and is highly valued as a country with expertise in producing electronics components. Indonesia serves as an assembly base, making the most of its low labor costs, while the Philippines, where English is used as an official language, has become a base for informationrelated products such as hard-disk drives and software. Thailand has fewer engineers than Singapore and Malaysia, but an abundant supply of line workers, a large domestic market, a higher average national income than Indonesia and the Philippines, and political stability; these factors have established Thailand as a production base for consumer-electronics products. In the past several years, investment in the region has centered on Thailand due to the political turmoil in Indonesia and the Philippines. Though the largest export category of Thailand is information technology (IT)-related appliances and parts, the export value of such products has fallen. In contrast, exports of home appliances have continued to climb. They will likely support the Thai economy to some extent, though the outlook depends partly on future demand.

After the Southeast Asian financial crisis of 1997, the Asian countries have taken different approaches to encourage economic development. A debate has been raging on the relative importance of factors that contributed to the financial crisis. A major line of thought is that many countries lacked a solid basis for sustained economic development by primarily relying on expanding the input of capital and labor. The corollary is that technology and education were neglected sectors. For example, Singapore has implemented policies to strengthen the domestic innovation and invention climate and to promote industrial innovation activities through 
grants and tax incentives. Singapore has also decided to train a large number of high-level researchers, even though foreign expatriates continue to play a dominant role in domestic R\&D. Malaysia has continued to strengthen planning and management in science and technology and to promote technology transfer among industries, government research institutes and universities. Innovations are also supported by tax incentives and subsidies.

This chapter will focus on two things. First, it will highlight some of the characteristics of the science and technology policies of selected ASEAN countries, namely the Philippines, Indonesia, Vietnam, Malaysia and Singapore. Second, it will discuss the shortcomings of the policies and examine the changes in technology systems which have taken place after the financial crisis. The analysis will focus on the interaction between the public and private sectors, as seen in the context of an ongoing globalization process.

Technological opportunities are opening up on a global scale and can be seen as parallel and complementary priorities in global companies and governmental industrial policies. The key to improving technology performance, as stated in OECD (1997) in a study of national innovation systems, dwells in the understanding of the linkages between the actors involved in innovation. Such an insight requires a broad and systematic knowledge of the domestic innovation system, of the systems in other countries, and of the increasingly interlocking character of large global companies. Without such intelligence, realistic national objectives cannot be formulated. Even so, goals and instruments still have to be constantly modified in light of the changes within a national innovation system that is increasingly taking on global characteristics.

The countries selected for this study, the Philippines, Indonesia, Vietnam, Malaysia and Singapore, not only exemplify countries at very different levels of economic development but also illuminate the very policies and conditions for their implementation. The Philippines has been weak in both formulation and implementation of policies, with rudimentary infrastructure and institutions for technological development, and has been less able to attract foreign direct investment (FDI). Indonesia has pursued a two-pronged policy of developing high-technology sectors and actively encouraging FDI. Both policies are partial failures because the infrastructure, institutions and human resources have been lacking. Vietnam has, in recent years, moved from a planned economy with well-developed institutions towards a market economy, which requires completely different policies and institutions. From its early success in attracting FDI of increasing sophistication, Malaysia has moved towards a selective development of high-technology sectors, for which clustering is an important policy instrument. Singapore decided at an early stage that it would integrate the nation with the global economy and has become a heaven for FDI in specific sectors. The success made 
Singapore into a high-wage country, which prompted a policy shift towards turning it into a knowledge-based economy. However, with the partial exception of Singapore, technology has not made as significant a contribution to the economic development of the countries as might be expected.

Skeptics may ask whether science and technology matters that much to the low income economies discussed in this chapter. On the other hand there is confirmation that the most sustainable growth is to be observed in the countries with a strong focus on knowledge-based economy (KBE) according to OECD (2001). The term KBE refers to the main drivers of growth in all the sectors of economy, not only those usually called "high technology". Four policy dimensions within KBE are identified as crucial for sustainable growth. They are: (1) innovation supported by a national innovation system; (2) human resource development; (3) information and communication technologies (ICT), efficient infrastructure for all businesses and individuals; and (4) legal and economic policies which take the business environment into account.

The liberal market forces are no doubt insufficient to solve the above issues. Effective government measures have to be implemented - thus the term "political economy of technological development" came into existence.

\section{Political economy of technological development ${ }^{2}$}

Technological change has been accelerated by globalization, as markets opened up and competitors looked to innovation as a means of gaining market advantage. The ever-increasing effects of globalization have raised several fundamental issues for developing countries. First, national policy makers aiming to catch up to more developed countries have to formulate science and technology programs that are in tune with the rapid technological development. Second, national governments are still keen to assist their own national companies, but it is no longer clear which companies are national as the identities of firms are increasingly blurred by the crossborder process of mergers and acquisitions. The first issue requires close interaction with a global system of innovation, with active science, technology and education policies. The second issue prompts a shift in policy focus from the micro to the macro level, where governments seek to influence the performance of firms and industries through the use of an active industrial policy.

The world economy shows broad inequalities that arise from globalization. A widening of disparities in technological capability between the more and the less technologically advanced countries is an important political issue of technological development. Many multinational companies have globalized their production, but few have shifted research and development capabilities or corporate headquarters away from their 


\section{Technological governance in ASEAN}

traditional home bases. An important reason for this situation is that technology, in terms of machines and blueprints, has become extremely mobile while the technological competence embodied in capable humans is much less so. Furthermore, it is recognized that the capacity to innovate is cumulative, as innovation gives birth to more innovation. A firm may shift its production facilities plant and machinery overseas, but people tend not to move. Knowledge and skills acquired over time by people who work in research remain key factors and it is not easy to pick up new, stateof-the-art technologies without the knowledge and the skills required for making good use of them.

This pattern of technological development has powerful political effects. Countries and firms that start with less sophisticated technological competence may be left behind and often find it very difficult to catch up. More intense competition between more firms pushes forward the development of ever more sophisticated technologies. This means that the process of competition reinforces the advantage of those in the lead and takes them further along the learning curve. The tendency for technological development to reinforce existing competitive advantages has powerful repercussions, well-illustrated by the development of the Internet, which has created a wide gap between industrialized and developing countries.

A further change in the political economy of research and technological development arises from new industrial structures. Nation states are scarcely able to influence the activities of large, oligopolistic multinational companies (MNCs) whose businesses and internal structures are global in scale, and can easily be shifted to new production sites. Simultaneously many MNCs with globalized activities have decentralized their productive and distributive capacities. The phenomenon is usually referred to as networked organizations and is constantly increasing in scope and scale. Countries must therefore develop catch-up policies with foundations strongly based on facilitating the access to new technologies and promoting foreign direct investments. ${ }^{3}$ Technologies diffuse more readily if they are embraced widely by citizens in democratic societies. However, the historical perspective of the last half of the 20th century in East Asia proves that strong but enlightened political regimes were more successful in imposing development-oriented catch-up policies than weaker governments.

Technology policies, which have traditionally been producer-driven, have to consider thoughtfully the demand side today. A broad and similar lesson may be drawn from the cases of nuclear power in the 1970s, cattle growth hormones in the 1980s and gene technologies in the 1990s. Technologies will not catch on unless they are viewed by citizens as safe, ethical and consumer-friendly. Thus successful diffusion depends just as much on social attitudes as it does on technology.

While examining the governmental structures of the selected countries, 
one finds a variety of state agencies with special responsibilities for education, technology and science. On the very top level there are the examples, as in the Philippines, of secretaries of the president's cabinet responsible for the area, corresponding in other countries to a respective ministry in the prime minister's office. The following summary is a first attempt to highlight the character of technology policy and technology development in five ASEAN countries by focusing on inherent features, perceived shortcoming and significant changes that have taken place during the past few years.

\section{The Philippines: the shortcomings of S\&T policies}

The Philippines rank low in several research and development (R\&D) indicators such as the ratio of $\mathrm{R} \& \mathrm{D}$ expenditure to GNP, which is very low. Similarly, the country ranks low in terms of number of personnel engaged in R\&D. A study from the Philippine Institute of Development Studies (PIDS) states that the number of scientists and engineers per million inhabitants was only 152 in 1992 . However, the composition of the national cabinet shows at least two bodies responsible for science and education, the Secretary for Education, Culture and Sports, and the Secretary of Science. The Secretary of Science leads the Department of Science and Technology (DOST).

The country's educational system produces few graduates in science and engineering, even though the number of students at the tertiary level is actually quite high in the Philippines. PIDS points out that there is a great demand for technical and engineering-related graduates by local industries but that the private tertiary schools primarily train non-technical students. An important reason for this mismatch is that the private colleges are unable or unwilling to invest in costly laboratory equipment. This mismatch continues at the next level of education and PIDS reports that more than 50 percent of $\mathrm{R} \& \mathrm{D}$ personnel with $\mathrm{PhD}$ degrees in government agencies, and state universities and colleges have their degrees in the social sciences.

The Philippines has failed to use technology to gain competitive advantage. Resource-based exports such as timber or copper are basically in raw material or unprocessed form. Traditional agricultural exports, such as coconut, sugar and banana are also exported without infusing technology-based processing in the valued-added chain. The overall assessment of the state of science and technology in the Philippines is at the level set by UNESCO for less developed countries. In terms of human resources, the Philippines has only 155 R\&D scientists and engineers per million inhabitants, far below the UNESCO target of 380 for Asian lesserdeveloped countries (LDCs). The Philippines needs to strengthen its education in science and engineering by updating the curricula, finding qualified teachers and procuring laboratory facilities. 


\section{Technological governance in ASEAN}

The Philippine government created the National Science and Development Board (NSDB) in 1958 to formulate and implement science and technology (S\&T) policies, and to co-ordinate S\&T agencies. In 1974, a national science development plan was incorporated in the Medium-Term Development Plan: 1974-1977. All succeeding Medium-Term Development Plans contained a chapter or sections related to S\&T policies, plans and programs. The Department of Science and Technology (DOST) introduced the Science and Technology Master Plan (STMP) in 1990 which set the goals and objectives for the S\&T sector, and provided a framework for the effective co-ordination of S\&T projects and programs consistent with national development policies. The Comprehensive Technology Transfer and Commercialization (CTTC) program was initiated to disseminate and commercialize locally developed technologies. But there was a lack of locally developed, commercially viable technologies. In 1993, DOST introduced the Science and Technology Agenda for National Development (STAND) as a successor to STMP.

STMP had three main strategies: (1) modernization of the production sector through massive technology transfer from domestic and foreign sources; (2) upgrading of R\&D capability through intensive activities in high priority sectors; and (3) development of S\&T infrastructure, including institution building, manpower development and development of S\&T culture. STAND's objective was to help realize the vision of the Philippines during the 2000s by focusing S\&T activities on export niches identified by the private sector. The renewed attempt to formulate industrial policy is a reiteration of the vital role of industrial progress to sustain future economic growth. However, ad hoc or de facto industrial policies have not stressed the need for active promotion of technology to build up a strong foundation for industrialization.

The major thrust of the Philippine S\&T policy has recently been subjected to contrasting recommendations. One view recommends that the universities and research institutes focus on the basic sciences and advanced technologies to provide the foundation for sustained technological development. This view is popularly called "supply-push" or "technology-push". The other view argues that it makes more sense for the government to provide an environment which enables the private sector to purchase the technologies that it needs.

The most reasonable conclusion that can be drawn is that neither STMP nor STAND can be implemented. Therefore DOST must effectively address the following problems: (1) shortage of high-quality S\&T manpower; (2) dependence on technology importation; (3) low level of private sector participation in R\&D; (4) low level of basic research in core, strategic and emerging technologies such as biotechnology, new materials science, robotics and information technology; (5) lack of a technology data bank and information network; (6) absence of science programs for the younger generation; and (7) insufficient financial resources for S\&T development. 
In the 2000s DOST undertook new initiatives under a new Science Secretary. The Medium Term Plan for 1999-2004 outlines the vision and priority goals for establishing a competitive science community. As a result, the department supported some 15,000 students and trained 1,635 teachers in science and mathematics in the year 2001. DOST also started the Philippine Research Education and Government Information Network, offering over 15 different technological assistance programs for small to medium enterprises (SMEs) through different DOST offices and agencies in the country. There are about 16 offices willing to help the local entrepreneur, among them the Technology Training Center, DOSTAcademe Technology, Global Technology Search, Municipal S\&T Program, Intellectual Property Rights Program and others. DOST also advertises and supports successful innovative initiatives via a well-designed website.

These new actions are too recent to be assessed; however, they are proof that the government is aware of the importance of country-internal visions of development in confrontation with dramatic cuts in FDI inflow in the late 1990s. To improve the Philippine R\&D delivery system, the authors suggest the following measures: (1) reorganize the governmentsupported R\&D institutes into a new corporate structure that gives them flexibility and autonomy; (2) strengthen the network of schools or consortia to maximize the use of resources and to develop core competence; and (3) promote the development of S\&T culture.

\section{Indonesia: the dominance of FDI}

Indonesia is one of the poorest countries in the region. It also has the most complicated ethnic structure and consequently, serious political problems. The manufacturing sector in Indonesia has sustained a high rate of growth for a number of years and both its share of GNP and exports have increased rapidly. New industrial sectors include electronics and transportation equipment, and the textile industry has become highly competitive through modernization. The above-mentioned phenomena can be attributed to the significant inflow of FDI. The government organization in Indonesia is relatively complicated with broad prerogatives given to provincial governors. However, at the state level, there is an office of Minister for National Education responsible for the overall science and education policy.

The technological foundation of the country is weak, as the capital goods sector is underdeveloped. The country's ability to absorb and improve imported technologies is also weak, particularly when it comes to complex technologies. A number of successful export industries controlled or propelled by FDI have remained concentrated in labor-intensive assembly or resource processing activities. Moving away from this pattern of development will require a significant reorientation of the country's 


\section{Technological governance in ASEAN}

technology strategy. Almost all R\&D activities in Indonesia are carried out in government research institutes (GRI), although there is an increasing demand for industrial $\mathrm{R} \& \mathrm{D}$ due to the rapid expansion of the industrial sector. This poses a challenge for reform as the GRI activities very rarely correspond to the needs within the industrial sector, in either their orientation or research results.

Since 1997 Indonesia's economic policy-makers have primarily concentrated their efforts on dealing with the most serious financial and economic crisis the country has faced since its independence in 1949. However, once macroeconomic stability is restored, the Indonesian economy will once again be facing the same challenge as before the onset of the crisis, namely how to sustain the growth of Indonesia's manufactured exports. Sustaining growth of the manufacturing sector is crucial, as it has emerged as the major engine of growth as well as the major source of foreign exchange earnings since the end of the oil boom era in the early 1980s. Indonesia can no longer continue to rely on its traditional sources of comparative advantage, namely its cheap but low-skill labor and its natural resources. Instead, it will need to develop a more sustainable base of comparative advantage, just like the first tier newly industrializing countries (NICs) in East Asia.

FDI is generally the major vehicle for the transfer of technology and other resources, such as capital, managerial and marketing know-how, and access to world markets, from the advanced to the developing countries. To what extent FDI leads to the development of local technological capabilities depends a great deal on the economic policies pursued by the host government as well as on the local absorptive capability, that is, the availability of adequately skilled human resources. Singapore, Japan and South Korea and, to a lesser extent, Taiwan, all pursued highly restrictive policies towards FDI, prioritizing the promotion of indigenous enterprises and deepening local technological capabilities; Indonesia, however, has not been very successful in using FDI to promote the development of local technological capabilities, despite the fact that it has been receiving large amounts of FDI since the late 1960s, at least until the severe economic crisis of 1997 virtually halted the inflow of new FDI. This failure has been caused by the fact that the Indonesian government has not taken a more pro-active approach to attracting the kind of FDI the country needed for promoting its industrial technology development.

Findings from some recent firm-level studies on the impact of FDI on Indonesia's industrial technology development within its manufacturing sector indicate serious shortcomings. Surveys indicate that in joint ventures the interest of the foreign investors in technology transfer was mainly limited to production engineering, that is, the smooth operation of the plants. As the foreign-controlled firms mostly relied on the designs developed by the parent company, their design capability is also low; the same can be said of the industrial engineering capabilities of the joint ven- 
tures. Also, during the period of import-substituting industrialization in the 1970 s and early 1980s, many foreign investors used obsolete technologies, specifically outdated capital equipment, as even with these technologies they were able to sell their products in the highly protected Indonesian domestic market. The technological development in Indonesia has shown that in most joint ventures, the technology transferred from the MNCs to the local employees has been limited to the very basic technological capabilities required for the early stages of industrialization, which is the skills and knowledge required for the efficient operation of the plant. Other factors which have hampered Indonesia from taking greater advantage of its FDI to promote technology transfer and diffusion have been the shortage of an adequately skilled labor force and the weakness of its few supporting supplier industries.

The development of industrial technological capabilities (ITCs) such as operational (production), acquisitive (investment), adaptive (minor change), and innovative (major change) capabilities, is essential. In order to obtain greater technological benefit from FDI than it has so far, the Indonesian government must pursue sound macroeconomic policies and pro-competition policies to ensure a competitive business environment. The country must also pursue a much more consistent and transparent policy to attract the FDI that it now needs, more than ever, for its economic recovery and subsequently for sustaining its economic growth and export-oriented industrialization. To achieve this, the Indonesian government needs to continue dismantling its cumbersome regulatory framework in order to further reduce the high facilitation costs associated with setting up a new plant or office. No less important, it needs to prioritize developing its human resources in order to raise their capacity to absorb, assimilate, modify and improve the imported technologies, whether transferred through FDI or purchased through technical licensing agreements.

For a developing country such as Indonesia, which still lags behind its East Asian neighbors in industrial development, industrial technology development does not primarily involve the costly development of new technologies. The development of industrial technological capabilities should, in the first instance, focus on developing the capacity to select, diffuse and build on imported technologies. A favorable incentive system conducive to industrial technology development should include policies which are macroeconomically sound as well as outward-looking and procompetition. This would motivate and encourage manufacturing firms to undertake the necessary but risky long-term investments in industrial technology development. The training of skilled people and improvements in the educational sector is, as in the Philippines, of crucial importance.

Recent research by Okamoto and Sjöholm (2003) on technological development in Indonesia summarizes the situation in the following five assumptions. First, S\&T policies that target specific high-technology industries will fail when the technological, managerial and institutional 


\section{Technological governance in ASEAN}

infrastructures are underdeveloped, and micro-level intervention cannot achieve desired objectives. Second, FDI is essential for technological development to offset constraints in domestic structures. However, FDI does not automatically generate technological spillovers and linkage effects, which require complementary actions and resources in the domestic economy. Third, systematic efforts are needed in the public sector to acquire, upgrade and disseminate technology and know-how when a country moves up the technological ladder, and will require direct government intervention. Fourth, external sources of technology are not only important but also essential in the early stages of industrial development and require efficient channels of transfer, which must be accompanied by openness to trade, investment and skilled labor. Fifth, the focus to the role of FDI in the globalization process has exposed the important but relatively unexplored issue of its link with human capital development. Indonesia must, like other developing countries, formulate efficient policies that can exploit the shift in demand for labor market that comes with increased FDI.

\section{Vietnam: top-down S\&T system}

The supply of scientific and technical expertise is of critical importance for Vietnam. Industrialization and economic growth have been at the forefront of the country's development strategy for a long time, although much attention has not been paid until recently to reforms and strategy in the domain of science and technology policy. Within the national government there are the Ministry of Science and Technology ${ }^{4}$ and the Ministry of Education and Training. The two powerful institutions managing research and technology policy on the state level are the Central Institute for Economic Management (CIEM) associated with the Ministry of Industry and Trade, and the National Institute of Science and Technology Policy and Strategic Studies (NISTPASS) affiliated with the Ministry of Science and Technology. These two institutions promote state programs and co-operate actively with foreign institutions.

The science and technology policies in Vietnam have been designed to encourage and support the acquisition of new technologies. However, taxation laws and the tax collection systems imposed constraints on the process of acquiring technology for enterprises, especially for the private ones. ${ }^{5}$ The new law for private enterprises, implemented in 2002, has changed the situation and doubled the number of SMEs in Vietnam into 70,000 , amounting to some 45 percent of the whole economy. The majority of the firms in the private sector, however, are located in agriculture and consist of so-called family-household activities. The situation has become more critical as information and communication technologies have become more pervasive at the same time as the economy of Vietnam has taken on an outward orientation. Given the opportunities of a know- 
ledge-based economy, there is an immediate need to identify the necessary structural reforms in the science and technology sector as the country is being integrated into the international economy. Remaining competitive in international markets will require the introduction and upgrading of technologies that will reduce the effect of rising labor costs.

After the exodus of the French in the late 1950s the science and technology system in Vietnam acquired a socialist stamp, with a direct and strong influence from the USSR and other socialist countries in Eastern Europe. These countries provided training and education for engineers, doctors and administrators and most Vietnamese S\&T programs were based on models from USSR and Eastern Europe. As a consequence, science and technology activities were almost completely isolated from the rest of the economy. Innovative activity was controlled from the top by decrees and prioritized capital goods and defense equipment. However, the economic reforms that were introduced in 1986 and the subsequent reforms have provided a policy orientation of cautious liberalization and decentralization. Furthermore, a fiscal crisis has been affecting the R\&D institutions in Vietnam. As a result, the state no longer monopolizes S\&T activities and serious budget constraints have forced government agencies to decentralize, privatize and even abandon a number of S\&T programs. The National Center for Natural Science and Technology exemplifies this new situation. The Center has come to rely extensively on contract research and consultancy, without which it would cease to exist, with a consequence that it has oriented itself towards applied research and the demand of industrial firms.

Another change is growing collaboration with foreign partners. The Foreign Investment Law and the Law on Science and Technology of 1995 are of particular importance as they include rules for the protection of industrial property rights, copyrights and also a legal framework to govern technology transfer. ${ }^{6}$

It is important for Vietnam that efficient mechanisms are established for a systematic monitoring of the technical change that is taking place in other countries. Only then is it possible to identify the appropriate means for obtaining, adapting and diffusing already available technologies to be utilized in Vietnam. However, the S\&T sector in Vietnam lacks the dynamic character that could boost the country's economic development, and the reasons are manifold. First, many research institutes are still dependent on government funding, which usually is insufficient due to budget constraints. Second, the linkages between enterprises and research institutes remain weak, or are almost non-existent, which reflect the lack of an articulated demand within the enterprise sector, which is still dominated by state-owned enterprises. Third, the opportunities for advanced overseas training have been quite limited since the 1980s, whereas many of the older generation of scientists and engineers received their training and higher education in the socialist planned economies. Fourth, there is 


\section{Technological governance in ASEAN}

a need for high-level training in areas like policy formulation and implementation, not only for science and technology, but also in other areas such as labor, environment, finance and macroeconomics. Finally, the state sector dominates the economy in Vietnam but is unlikely to be an engine of growth during the present decade. An important reason is that the state-owned enterprises (SOEs) will not generate enough jobs to absorb a significant share of the new entrants into the labor market, which is estimated to be in the region of 1.2-1.4 million persons per year. ${ }^{7}$ Thus, private SMEs, and joint ventures with FDI partners, will play an increasingly important role in the country's economic development.

During the past few years Vietnam has been experiencing serious political and economic difficulties in its transition from a centrally planned economy to an economy based on risk-taking and incentives, where the government's role should be limited to general guidance and encouragement. Under these circumstances, it is critical that Vietnam develop a capability to analyze the country's scientific and technological environment, both domestically and internationally. This capability should be brought forward to include advanced skills to formulate and implement a science and technology policy that is appropriate to a constantly changing environment. A recent report by Kang (2001) says that there seems to exist a strong commitment to integrate the science and technology system with national social and economic objectives, and also to make S\&T an integral part of the country's industrialization efforts. The innovative idea of establishing a private education system in Vietnam is welcomed in engineering sciences but meets some resistance in the social sciences. ${ }^{8}$ There have been a number of policy changes to make research demanddriven and create more autonomy for research institutes. However, the half-hearted implementation of these policy changes remains the major hurdle for the efficient use of science and technology resources in Vietnam.

\section{Malaysia: technology modernization}

In its long-term visionary plan for 2020, Malaysia strongly emphasized the role of R\&D for technological development. This is also reflected in its Action Plan for Industrial Technology (TAP 1990), and is also underlined in the Third Outline Perspective Plan 2000 prepared by the Economic Planning Unit (2000). The Malaysia National Council for Scientific Research and Development (MPKSN) plays an important role in co-ordinating and developing the country's resources for R\&D. Among government ministries there are the Ministry of Education and the Ministry of Science, Technology and Environment.

In a first inventory taken in 1994 of Malaysia's human resources in $\mathrm{R} \& \mathrm{D}$, it was found that the number of researchers per 10,000 people is only 2; the corresponding figure for Singapore is 40 . The GDP per capita 
expenditure on education places Malaysia in second place after Singapore among the five analyzed countries in this study. The low number of tertiary students is considered a consequence of the huge numbers of Malaysian students being educated abroad. ${ }^{9}$

Malaysia has substantial industrial activities in the electronics industry, in particular in packaging integrated circuits (ICs); basically all global manufacturers of ICs have a portion of their activity located in Malaysia. This reflects the fact that Malaysia has been perceived as an attractive location for economic and other reasons. The latter factors include the country's political stability, the welcoming attitude of the Malaysian government as expressed in a number of favorable government policies, good infrastructure in urban areas, a highly productive labor force, and well developed financial and banking sectors. Following its earlier emphasis on FDI as an instrument for employment generation, Malaysia has substantially upgraded its technological capabilities, which has encouraged existing FDI to expand into more sophisticated production.

MIGHT was set up in 1993 as an independent non-profit company providing a platform for government and industry collaboration. Organizationally it is located under the office of the Science Advisor in the Prime Minister's Department and led by a joint industry-government board. In the words of its chief executive, Dr Ahmed Tasir, MIGHT is, "[i]n a nutshell,... a symbiotic relationship between the private and public sectors of Malaysia for the pursuit of a common goal of heralding a new era of technology-led development in the country". MIGHT's activities are focused on the following sectors earmarked for national development: aerospace, advanced materials, low emission vehicles, telecommunications, road haulage, pharmaceuticals, and housing and construction.

Malaysia has, under the leadership of its former Prime Minister Dr Mahathir Mohamad, taken a bold visionary initiative in establishing a Multimedia Super Corridor (MSC) close to Kuala Lumpur. "The Multimedia Super Corridor (MSC) is Malaysia's gift to the world". On this note almost all presentation materials on the MSC commence, making clear that the MSC initiative, launched in 1996, is an open invitation to the global multimedia community. The MSC is a $15 \mathrm{~km}$ by $50 \mathrm{~km}$ "green corridor" approximately the same size as Singapore, stretching from the Kuala Lumpur City Center in the north to the new Kuala Lumpur International Airport located in the south. Two new cities are taking form within the MSC: Putrajaya, the new administrative seat of the federal government, and Cyberjaya, the new IT city. The latter will consist of enterprise, commercial and residential precincts and will also include public and recreational areas. Cyberjaya is to be the core development zone of the MSC, and will have an estimated population of 240,000 (90,000 residents) and will have some 500 IT and multimedia companies by the year 2020 . Unfortunately the financial crisis and a bigger than threefold drop in FDI have drastically curtailed the forecast results for MSC, as "Silicon Valley of Southeast 


\section{Technological governance in ASEAN}

Asia". The MSC remains so far in a state of infancy and it is therefore not possible to make any evaluation of the project.

The task of leading the management and development of the MSC is handled by the Multimedia Development Corporation (MDC), a government-appointed and government-backed corporation. MDC promotes and facilitates the application process for companies wishing to receive MSC status, expediting permit and licence approvals, and establishing contacts with local partners and financiers. Being a government-owned corporation that was actively supported by the former prime minister Dr Mahathir, MDC has the unique ability of cutting through bureaucratic red tape, guaranteeing a 30-day turnaround for all applications. MDC has set a 20-year timeframe for the full implementation of the MSC, at the end of which Malaysia expects to be one of the leaders of the Information Age. The success of the MSC rests on the successful development of four supporting pillars: (1) soft infrastructure, i.e. legislative framework, manpower, attractive incentives; (2) physical infrastructure; (3) high-capacity telecom infrastructure; and (4) the MDC. To attract companies to establish themselves within the MSC, and receive "MSC status", a promising Bill of Guarantees complemented with generous financial incentives has been set up.

The budding technological capability in Malaysia owes its existence to an early nurturing of FDI and a strong commitment by the government to support selected sectors by developing infrastructure and formulating appropriate policies. There are, however, problems arising from the fact that the special economic zones like the MSC do not integrate with the rest of economy, as there are artificial barriers between them, and there are also significant differences between regions in terms of economic development and local policies. For example, the relatively successful development of Penang as a "mini-Singapore" is a result of the local government policy supporting mainly Chinese SMEs; this is quite contrary to the federal attitude towards the Chinese minority. Despite the potential technological capability, however, Malaysia still lacks the educational resources to sustain continued and rapid technological development.

\section{Singapore: a global center for $R \& D$}

After Japan, Singapore is one of the most technologically advanced countries in the Asia Pacific. It has started to implement large-scale changes in its knowledge and information sectors as they are expected to become the most important factors for future economic growth. Singapore has declared that it wants to turn the nation into a knowledge-based economy. This declaration is expressed by the most developed system of government ministries devoted to accomplish the task. They include the Ministry of Education, the Ministry of Communication and Information Technology, and the Ministry of National Development. 
Singapore has realized that it is in need of a post-crisis growth strategy as it feels threatened by both developing countries such as China, which has price competitiveness owing to its low labor costs and cheap production costs, and by developed countries such as the United States, which has technological competitiveness and production efficiencies. Therefore, Singapore feels some pressure to shift its development strategy from a traditional government-led industrialization strategy to a different strategy that can utilize Singapore's most important competitive advantage, namely, its well-educated population. Singapore's economy should be transformed into a knowledge-based economy. A knowledge-based strategy consists of making more effective use of new and existing knowledge and technology throughout the whole economy. There are four important elements in a knowledge-based strategy: (1) an economic and institutional regime that provides incentives for the efficient use of existing knowledge and the creation of new knowledge and new businesses; (2) an educated and skilled population that can create and use knowledge; (3) a dynamic information infrastructure that can facilitate the effective communication, dissemination and processing of information; and (4) an effective innovation system where enterprises, research centers, universities and other organizations interact effectively to create and diffuse technologies using the growing stock of domestic and global knowledge.

Singapore has a small population and limited space. The state has created an attractive climate for foreign high-technology companies to locate within this limited area. This has been achieved through a combination of tax incentives, government investments and subsidies, and more recently through development of an R\&D infrastructure. For example almost one half of the global production of hard disk drives takes place in Singapore, contributing about 12 percent of GNP. In terms of the share of FDI in its gross domestic investment, Singapore is one of the most FDIintensive economies in the Asia Pacific region, and in the world. However, Singapore has encouraged internalized modes of technology transfer, although by thoroughly targeting the FDI selection and the process of technology development. It has extensively used subsidies and other incentives to encourage foreign companies to bring in more advanced technologies and thereby boost local technological activity. Although industrial activity in Singapore is mainly driven by foreign MNCs, the country's continuously upgraded technological skills allow its industries to contribute considerably in terms of local design and development. The nature of FDI into Singapore has become increasingly sophisticated and is a key instrument for the continual upgrade of the economy. The adoption of a very liberal immigration policy is aimed at attracting foreign professionals and skilled labor to become permanent residents and offset the local workforce shortages. The government is also an active player in driving the economic development by establishing state-owned enterprises or government-linked corporations in key industrial areas that are either 


\section{Technological governance in ASEAN}

not satisfactorily pursued by the private sector, or deemed to be of strategic national importance.

Singapore's R\&D activities are similar to the industrial structure of the country, and closely geared to meet the needs of information technologies; a number of R\&D organizations are specifically focused on IT development. Launched in 1996, the second five-year National Science and Technology Plan, NSTP 2000, projected S\$4 billion in government spending until the year 2000, which is twice the figure allocated for 1991, representing 1.6 percent of gross national output but still short of the 2 percent goal. The number of research scientists and engineers (RSEs) was targeted at 65 per 10,000 labor force.

Several new organizations were established in the mid-1990s to strongly support the country's S\&T policies. The National Science and Technology Board (NSTB) focuses on basic research while the Economic Development Board concentrates on applied and development activities. Offering high salaries and an open labor market, by 1999 Singapore has been able to attract about 17 percent of its science and technology personnel from foreign countries. Generous grants have been offered to MNCs to undertake R\&D activities and the Skills Development Fund offers substantial funds for training. However, the linkages between public research institutes and enterprises lack efficiency and the mobility of local researchers may pose a long-term threat.

NSTB provides the Singapore government with a policy framework to guide and support national research and technological diffusion through activities such as fiscal incentives, R\&D funding, infrastructure and manpower development and national research facilities, including eight research institutes and five research centers. Today, the key industry and service clusters targeted for development by NSTB are: manufacturing and engineering systems, information technology and services, electronic components and systems, chemicals and environmental technology, and life sciences such as biotechnology, food and agro-technology.

Under the guidance of its Economic Development Board (EDB), Singapore is undertaking ambitious biomedical initiatives such as the building of a clinical trials center for drug manufacture and the development of a genetic reference database program and bioinformatics center. The database will be established by the Singapore Genomics Program (SGP) in collaboration with the Massachusetts Institute of Technology. The Bioinformatics ${ }^{10}$ Center (BIC), which was established in 1966 with funding from EDB, plays a leading role in the Asia-Pacific Bioinformatics Network, and went through a major reorganization in 2000 to give it a more commercial edge.

Singapore is already recognized as a pharmaceutical-manufacturing center. International companies like Aventis, Glaxo Smith-Kline, Merck Sharp and Dohme, Schering-Plough and American Home Products have invested over $\$ 1.3$ billion in plants to produce active pharmaceutical 
ingredients and finished products, according to the Far Eastern Economic Review (Witty 2001). Glaxo also co-ordinates its clinical trials research for the Asia-Pacific region out of Singapore.

Singapore's very focused aim at becoming a developed nation soon after the turn of the century starts from the National Innovation Framework for Action (NIFA), which was made public in January 1998. The NIFA document was prepared during 1997 by three agencies: the Economic Development Board (EDB), National Science and Technology Board (NSTB) and Singapore Productivity and Standards Board (SPSB). Taking into consideration the recent regional currency turmoil, the framework aims to be the starting point from which an innovation roadmap for Singapore can be developed. The underlying rationale for NIFA is that Singapore can no longer rely on labor and capital to sustain growth in the global economy. The new competitive environment forces Singapore to focus on enhancing capabilities to be able to compete globally in new areas. Innovation is identified as the instrument that will give Singapore a differential advantage in the third millennium. Previous instruments promoting and encouraging technological innovation, development and commercialization are not considered sufficient. Innovation will be the differentiating factor in sustaining Singapore's long-term competitiveness because it will allow rapid advances in capability and valueadded growth.

Impressed observers argue that if any country can break into the lifesciences industry from a standing start Singapore probably has the best chance. The government in Singapore has a track record in other fields of sticking to its plans, which is important as the development of a lifesciences industry will require a sustained effort over many years. However, critics say that Singapore will only gain jobs and training from its huge investments in biomedical science. They argue that students and researchers will consider Singapore as little more than a stopover in their careers. It remains an open question whether Singapore will be able to compete with cities such as Shanghai and be able to create a critical mass of first-class scientists and infrastructure to successfully commercialize products.

\section{The China factor}

China has become the great competitor for all Southeast Asian countries. It already challenges the region in terms of attracting foreign direct investment, and it will be a threat to Southeast Asia's world trade. As China becomes the world's leading supplier of mass-produced goods, Southeast Asia, as well as Japan and South Korea, will have to opt for niche products of high quality and prestige. During the past 20 years China has emerged as the "workshop of the world" leaving Japan behind. However, it would be a great mistake to continue to view China as the "workshop", as it is 
rapidly advancing in many technological fields, although its technological prowess still lags behind.

The moves by Minolta Co. in Japan illustrate these ongoing changes, according to the Nihon Keizai Shimbun (2002). Minolta hopes to enhance cost competitiveness and earnings by moving almost all production of IT equipment, accounting for nearly four-fifths of consolidated sales, as well as low-end cameras, to locations outside of Japan. It plans also to halt domestic production of photocopiers, printers and other equipment and shift the production to two plants in China by 2006. During fiscal year 2002 Minolta halted the production of cameras in Malaysia and moved it to Shanghai.

China has attracted MNCs to establish not only their production bases but also sites for industrial research and development in China. Furthermore, although the size of the Chinese market is attractive in itself, hightech companies that want to serve FDI plants in China are subsequently forced to establish themselves if they want to remain suppliers there. Thus, China is becoming a center for companies like Flextronics and Solectron that provide electronic manufacturing services (EMS) to the large electronic MNCs like Alcatel, Siemens, HP and Ericsson. In early 2002 Flextronics launched its industrial park in Shanghai and has thereby brought the concept of electronics manufacturing services (EMS) to China.

The same consequences are visible in more mundane industrial sectors like motorcycles and cars. The massive importation of motorcycle components into Vietnam in recent years indicates a loosening of the government control of technology and industrial policy according to CIEM (2002). In an interview in mid-2002, a leading Chinese exporter of motorcycles provided the following information to Vietnam. ${ }^{11}$ The recent rapid expansion of exports to Vietnam indicates great possibilities for the motorcycle manufacturers in China, and possibly also for other engineering sectors. Hardly any Chinese motorcycles were exported to Vietnam in 1988 while Chinese companies captured 16 percent of the market in 1999 of which Lifan \& Honda captured almost one-quarter, or 3-4 percent of the market in Vietnam. Dr Li says that the prediction is that motorcycles from China will capture some 30 percent of the market in Vietnam in 2000 and it is expected that this share will increase substantially.

The emergence of strong industrial and technological prowess is also evident in the car industry where the emergence of the Chery and the Merie, two locally made cars that have unexpectedly materialized during 2002 as the fastest selling models and taken everyone by surprise. An important part of the success lies in the rapid development of the Chinese car parts market that companies such as Volkswagen, Citroën, Peugeot and Fiat have worked diligently to develop since they entered China in the mid-1980s. As a result, car parts that are often identical to foreign brand 
components are today manufactured by thousands of Chinese companies, and are being sold on the open market.

However, the consumer electronics market has already seen the emergence of new players, some of which are aiming for global markets. One is Changhong in Sichuan, which in a few years has become one of China's leading manufacturers of TV sets. The company has acquired other TV producers in Jilin and Jiangsu and the latter acquisition has been motivated by a desire to move into the overseas market. Changhong views both Southeast Asia and Australia as promising markets.

China's emergence as a global actor in electronics is the most conspicuous development in recent years and the International Finance Corporation predicts that in 2005 China will be handling 50 percent of the final assembly of electrical and electronics products turned out in the world. This has far-reaching consequences for the location of manufacturing plants for semiconductors and many other components and services in the whole region. It is worth mentioning, however, that China is also becoming an important locomotive for Asian countries since its imports from the region continue to increase and create new employment and business opportunities.

\section{Conclusion: the future of S\&T in ASEAN countries}

The selected ASEAN countries, discussed in this chapter, have to cope with the rapid development of technology that lies at the core of the crossnational production systems (CNPS) that in the past have greatly supported export-oriented policies, originally based on labor-intensive assembly. Many manufacturers of IT products established large manufacturing networks in the region. The past two decades of technology-driven mass-manufacture in Southeast Asia have given many countries in the region a physical infrastructure that can compare with that of Europe, such as wide roads, uninterrupted electricity, and modern ports and airports. However, the CNPS require much less manpower as both product and production technology rapidly changes. At the same time, China is becoming the preferred location for many activities.

The FDI inflow into the chosen countries decreased dramatically in the late 1990s, and the ranks of the recipients have been reshuffled. Indonesia and the Philippines appear the most vulnerable in this respect, partly due to the countries' political turmoil, whereas Singapore and Vietnam remain relatively immune.

The countries covered in this chapter continue to differ in performance. Singapore has successfully kept ahead of its counterparts in the region by maintaining its second place ranking for competitiveness according to IMD (2000). Malaysia has been going down the rankings and Thailand, the Philippines and Indonesia are even lower. The technological development in the five countries that have been briefly reviewed 
shows a number of similarities with the exception of Singapore. The other four countries are still bogged down by low-skill workers and low productivity, and they require new key elements of competitiveness, which will have to come from enhanced capability in production, marketing and services. The structure of their economies is changing but agriculture remains a substantial part of their GDP composition.

Vietnam still remains a very poor country but has introduced significant reforms for privatization and supporting private companies. The most critical issue for the country is the level of education and the technological capabilities of private businesses located in particular in agriculture. Though they have relatively low labor costs, countries like Indonesia and the Philippines are being forced to restructure. Examination of the structural problems of countries like Indonesia, the Philippines and Vietnam reveals a serious lack of human and social capital needed for sustainable participation in the global economy. Although they have large populations, these countries lack the capability required for keeping abreast of the continually changing work demands. The importance of strategic, long-term policy and planning in science, technology and education is very clear, from the fact that they need both considerable resources in order to carry out the planned activities, and a long lead time to accumulate the required trained manpower.

Factors contributing towards competitiveness include people, infrastructure, good governance, management and science and technology. Each factor depends in turn on a number of variables, but a key variable governing all of these factors, to a greater or lesser extent, is innovation. Innovation is defined here, not in a narrow technical sense, but as a broad dynamic process of introduction of new beneficial elements into a system, which will lead to better, more efficient performance of the system.

A lack of sustainability characterizes the development paths of many countries in Southeast Asia, although the future of these countries is intimately linked with the future of their science and technology and education. A shift in focus of the role of FDI in the globalization process has brought to the forefront the important but still relatively unknown linkage between FDI and the development of human capital. By their exposure to the global economy, MNCs operating in Southeast Asia create an awareness of modern technology and modern management in the host countries. In order to fully utilize this new knowledge, the host countries should shift their educational policies to not only meet the demands of the MNCs but to also diffuse the knowledge throughout the economy.

A balanced development is required, with emphasis placed on niche areas where these countries have strategic advantages. If a government wants to be successful in using technology to achieve rapid economic growth, it must not only identify and adopt the right basic technology but also be able to implement it effectively, according to Lee (2001). This requires that the country has institutional mechanisms that foster private 
investment, has a competent bureaucracy that can implement adopted policies, and also has institutions that facilitate communication between the state and private sectors.

Southeast Asia in general has to develop new technology-based and management-based capabilities, which will allow the countries to offer higher quality or new goods and services at competitive prices, hence finding new niches in global trade. It should be noted that the technology base required for new competitiveness does not necessarily require massive investments in R\&D resources.

Many countries in the region have now spearheaded their efforts in strategic planning by issuing long-term policy statements, such as Malaysia's Vision 2020, and ASEAN Vision 2020. The current technological system operates largely within a market-based framework in most countries. There is a need for transparency in both the nature of technology, as well as the decision-making process. Exposing the decision-making process goes a long way to ensuring better public accountability. It is therefore not surprising that technological projects have greater public accountability in those countries where the media has a high degree of freedom.

\section{Notes}

1 This chapter is partly based on a project, "Technological Mapping of Asia Pacific", that was started in 1998 with partial results appearing in Sigurdson and Cheng (2001b).

2 This section is based on a discussion in Peterson and Sharp (1998).

3 The issue is strongly stressed by APEC (2000), where KBE status indicators are recommended.

4 Until mid-2002 it was called the Ministry of Science, Technology and Environment (MOSTE).

5 This problem is highlighted in IDRC (1998).

6 The new Science and Technology Law came into existence in 2002 with more autonomy for research institutions and individuals. It also covers the intellectual property rights issue.

7 CIEM (2002: 124-125).

8 Australia's Royal Melbourne Institute of Technology has a newly established branch campus in Ho Chi Minh City and Harvard University and Connecticut College are initiating training programs and academic exchange, according to Far Eastern Economic Review (2002).

9 See Chapter 2, "Educational Reforms and Challenges in Southeast Asia", by Fredrik Sjöholm in this book.

10 Bioinformatics is an interdisciplinary research area that may be broadly defined as the interface between biological and computational sciences. It involves solving complex biological problems using computational tools and systems. It also includes the collection, organization, storage and retrieval of biological information and databases.

11 Interview with Manager in Charge of Marketing at Lifan \& Honda in Chongqing, China, 9 June 2000. 


\section{Technological governance in ASEAN}

\section{References and Bibliography}

APEC Economic Committee (2000) Towards Knowledge-based Economies.

Blomström, M. and Kokko, A. (1998) "Multinational corporations and spillovers", Journal of Economic Surveys, 12(3): 247-277.

CIEM (2002) Vietnam's Economy in 2001, Hanoi: Central Institute for Economic Management and National Political Publishers.

Dodgson, M. (2000) "Policies for science, technology, and innovation in Asian newly industrializing economies", in L. Kim and R.R. Nelson (eds) Technology, Learning, and Innovation: Experiences of Newly Industrializing Countries, Cambridge: Cambridge University Press.

EPU (2000) Third Outline Perspective Plan 2000, Kuala Lumpur: Economic Planning Unit, Government of Malaysia.

Far Eastern Economic Review (2002) “Open minds open doors”, 28, 1 August 2002.

Funston, J. (ed.) (2001) Government and Politics in Southeast Asia, Singapore: Institute of Southeast Asian Studies.

Hill, H. and Thee, K.W. (eds) (1998) Indonesia's Technological Challenge, Singapore: Institute of Southeast Asian Studies.

Hobday, M. (1999) "Understanding innovation in electronics in Malaysia", in K.S. Jomo and G. Felker (eds) Technology, Competitiveness, and the State: Malaysia's Industrial Technology Policies, London: Routledge.

— (2001) "The electronics industries of Pacific Asia", Asia-Pacific Economic Literature, 15(1): 13-29.

IDRC (1998) Vietnam at the Crossroads: The Role of Science and Technology, report of the International Mission, Toronto: International Development Research Council.

IMD (2000) World Competitiveness Yearbook, Lausanne: International Institute of Management Development.

Jomo, K.S. and Felker, G. (eds) (1999) Technology, Competitiveness, and the State: Malaysia's Industrial Technology Policies, London: Routledge.

Kang, O.H.-K. (2001) "Science and technology strategy review in Vietnam", EIJS Working Paper No. 133, European Institute of Japanese Studies, Stockholm School of Economics, October 2001.

Kynge, J. (2002) “China's reverse shock”, Financial Times, 7 June 2002.

Lall, S. (1998) "Technological capabilities in emerging Asia", Oxford Development Studies, 26(2): 213-244.

- (1998a) "Technology policies in Indonesia", in H. Hill and K.W. Thee (eds) Indonesia's Technological Challenge, Singapore: Institute of Southeast Asian Studies.

Lee, C.H. (2001) "The state and institutions in Asian economic development", EIJS Working Paper No. 127, European Institute of Japanese Studies, Stockholm School of Economics, June 2001.

McKendrick, D.G., Doner, R.F. and Haggard, S. (2000) From Silicon Valley to Singapore: Location and Competitive Advantage in the Hard Disk Drive Industry, Stanford: Stanford University Press.

Mathews, J.A. and Cho, D.-S. (2000) Tiger Technology: The Creation of a Semiconductor Industry in East Asia, Cambridge: Cambridge University Press.

NSTB (1997) National Science and Technology Plan, Singapore: National Science and Technology Board. 
(2000) National Survey of REDD in Singapore, 1999, Singapore: National Science and Technology Board.

Nihon Keizai Shimbun (2002) "Minolta shifts production of key products to China", 1 April 2002.

OECD (1997) National Innovation Systems, Paris: Organization for Economic Cooperation and Development.

- (2001) The New Economy - beyond the hype, Paris: Organization for Economic Cooperation and Development.

Okamoto, Y. and Sjöholm, F. (2001) "Technology development in Indonesia", EIJS Working Paper No. 124, European Institute of Japanese Studies, Stockholm School of Economics, published as Okamoto, Y. and Sjöholm, F. (2003) "Technology development in Indonesia", in S. Lall and S. Urata (eds) Competitiveness, FDI and Technological Activity in East Asia, London: Edward Elgar.

Peterson, J. and Sharp, M. (1998) Technology Policy in the European Union, London: Macmillan Press.

Ramstad, E. (2003) "Venture with Thomson gives TCL global role - lo-key Chinese company emerges as world leader with deal to make TV sets", The Wall Street Journal (Europe), A5, 4 November 2003.

Rasiah, R. (1999) "Malaysia's national innovation system"; in K.S. Jomo and G. Felker (eds) Technology, Competitiveness, and the State: Malaysia's Industrial Technology Policies, London: Routledge.

Sigurdson, J. and Cheng, A.L.-P. (2001a) "Introduction", A New Technological Landscape in Asia Pacific, special issue of the International Journal of Technology Management, 22(5/6).

- (eds) (2001b) A New Technological Landscape in AsiaPacific, special issue of the International Journal of Technology Management, 22(5/6).

Sigurdson, J. and Persson, O. (1998) "The new technological landscape in Pacific Asia: an enquiry into the dramatic changes in patenting and scientific publishing”, Research Evaluation, April: 31-38.

Soesastro, H. (1998) "Emerging patterns of technology flows in the Asia-Pacific region: the relevance to Indonesia", in H. Hill and K.W. Thee (eds) Indonesia's Technological Challenge, Singapore: Institute of Southeast Asian Studies.

Taiwan News (2002) "MAC backs restrictions on China-bound tech workers", 9 April.

Thee, K.W. (1998) “The determinants of Indonesia's industrial technology”, in H. Hill and K.W. Thee (eds) Indonesia's Technological Challenge, Singapore: Institute of Southeast Asian Studies.

The China Post (2002) "Taiwan needs science tech protection laws to safeguard security", 10 April.

Witty, A. (2001) "Discovering drugs in Singapore", Far Eastern Economic Review, 5 November.

Wong, P.K. (2001) "From leveraging multinational corporations to fostering technopreneurship: the changing role of S\&T policy in Singapore", in L. Low and D.M. Johnston (eds) Singapore Inc: Public Policy Options in the Third Millenium, Singapore: Asia Pacific Press. 


\title{
4 Interest rate policy and its implication on the banking restructuring programs in Indonesia $^{1}$
}

\author{
Reza Y. Siregar
}

\section{Introduction}

The impact of the 1997 financial crisis on the economic activities of the East Asian economies proved to be considerably more severe than expected, both reflecting and revealing weaknesses in domestic financial and corporate institutions, and inappropriate government policies. Output in the most affected economies of Southeast Asia fell dramatically in 1998 (CEIC Database). External borrowing, particularly by the private sector at the outset of the crisis, has often been cited as one of the key factors responsible for the severity of the crisis (Bhagwati 1998, Corsetti $e t$ al. 1999, Kawai 2002, Rajan and Siregar 2002). In Indonesia, corporations were the principle borrowers from foreign sources, while in South Korea banks were the primary borrowers from the external markets. Despite the varieties in the patterns of borrowing among the crisis-affected economies in East Asia, the combination of rigid exchange rate policies and high domestic interest rate policy was, however, inarguably an important factor for massive offshore borrowing by the domestic financial institutions, particularly in the late 1980s and early 1990s.

To deal with the economic crisis, a number of recovery programs have been drafted and signed jointly by the government of Indonesia and the International Monetary Fund (IMF) since late 1997. ${ }^{2}$ Restructuring the banking sector is one of the most urgent challenges facing Indonesia after the 1997 crisis. Both private and state banks saw their credits take a sharp dive after 1997, contributing to the overall drop in the banking credit outstanding by more than 50 percent in 1999 (Table 4.1). Private banks have always been the largest credit providers to the domestic industries and households from the early 1990s until the start of the 1997 financial crisis. In 1999, domestic private banks saw their total nominal credit outstanding drop most dramatically, contributing to more than 52 percent of the total credit decline in the banking industry. Though subsequently the credit outstanding has increased steadily in 2000 and 2001, the amount in 2001 was still less than 70 percent of the amount in 1997.

The fall in the supply of bank loans has been found to be responsible 
Table 4.1 Banking credits outstanding in Indonesia, 1996-2001

\begin{tabular}{lrrrrr}
\hline & 1997 & 1998 & 1999 & 2000 & 2001 \\
\hline $\begin{array}{l}\text { State banks } \\
\text { (a) Total in Rp billion }\end{array}$ & 153,266 & 220,747 & 112,288 & 102,061 & 117,104 \\
(b) Growth rate in percent & 40.7 & 44 & -49.1 & -9.10 & 14.8 \\
& & & & & \\
Private banks & 176,262 & 199,931 & 62,805 & 92,531 & 117,291 \\
(a) Total in Rp billion & 12.7 & 13.4 & -68.6 & 47.3 & 26.8 \\
(b) Growth rate in percent & & & & & \\
Total banking credits outstanding & 378,184 & 487,466 & 225,171 & 269,036 & 307,628 \\
$\quad$ in Rp billion & & & & & \\
Growth rate of total in percent & 29.1 & 28.9 & -53.8 & 19.5 & 14.3 \\
\hline
\end{tabular}

Source: World Bank (2003).

for the "liquidity crunch" reported during the post-crisis period (Siregar 2003). Despite the development of other financial institutions, such as the capital market and the non-banking financial institutions, the dependence of the private sector on the domestic banking sector has always been very high in Indonesia (Pangestu and Habir 2002). Most firms, particularly the small and medium-sized enterprises, continue to rely on the domestic financial institutions. To oversee the restructuring programs of the banking sector, the Indonesian Banking Restructuring Agency (IBRA) was established in January 1998.

Other cornerstones of the agreements between the IMF and the government of Indonesia include efforts to stabilize the domestic currency and to adopt a tight monetary policy (Johnson 1998, Soesastro and Basri 1998). These two programs were recognized as particularly critical for managing inflationary pressures in the country during the crisis period (Siregar and Rajaguru n.d.). The tight monetary policy program specifically required the government of Indonesia to limit the growth rate of its broad monetary aggregate (M2), to be achieved through controlling base money (M0) quarterly growths. Given the limited choice of monetary policy instruments, the Central Bank of Indonesia largely resorted to a high interest rate policy to achieve those targets of a stable rupiah and base money during most of the period after 1997.

However, despite a number of changes in the leaderships of the IBRA ${ }^{3}$ and in the policy approaches adopted by the country to restructure the banking sector, the progress has been less than impressive. In its recent report on Indonesia, the IMF (2002) underscores four key factors that explain the low asset recovery rates under the management of the IBRA: (1) the high degree of impairment of transferred non-performing loan assets; (2) overvaluation of pledged shareholder assets when originally 


\section{Interest rates and banking reform in Indonesia}

transferred to IBRA; (3) weaker conditions in Indonesia's financial and property markets than originally anticipated; and (4) depreciation of assets since they were transferred to IBRA, in part due to poor management of these assets by IBRA. The report also stresses the fact that the IBRA has had only limited success in enforcing its claims through the courts or by using its quasi-judicial powers. By the end of 2001, IBRA had processed 2,400 litigation cases, of which 2,125 cases were through the civil courts and 68 cases were brought to the bankruptcy court. Of the total, only 230 were settled as of the end of 2001 , with IBRA mostly on the losing side (IMF 2002). ${ }^{4}$

This study will show that the selection of policy measures adopted by the monetary authorities during the financial crisis has also adversely affected the performance of the restructured banks, and thus further deteriorated the face value of the assets. In particular, we will show that the high domestic interest rate policy adopted to stabilize the local currency and to keep a tight growth of base money has not been an effective measure. Instead, this policy has arguably worsened the environment for reforms and raised the costs of the bank restructuring.

The outline of the chapter is as follows. We will briefly highlight the severity of the impact of the financial crisis on various parts of the economy by presenting a number of key economic indicators, including the high cost of bank restructuring in Indonesia. This is followed by a discussion and an analysis of trends and policy debates on the three key monetary indicators (the domestic interest rate, the nominal exchange rate of the rupiah against the US dollar and the base money). Empirics are then presented to investigate the effectiveness of the interest rate policy in achieving its objectives of a stable rupiah and base money, and the final section presents evidence of the adverse consequences of the interest rate policy on selected performance indicators of the restructured banks. Brief concluding remarks end the chapter.

\section{The meltdown of the Indonesian economy}

In this section, we highlight the economic impact of the 1997 financial crisis in Indonesia. To start with, a set of key macroeconomic indicators will be presented to portray the overall meltdown of the economy. Brief notes on the cost of financing the bank restructuring in the country will then be presented in the last subsection.

\section{Macroeconomic conditions}

The collapse of the financial sector

The Indonesian economy reported its worst growth rate in 1998, contracting by around 13 percent (Table 4.2 ). It was the most profound economic 
Table 4.2 GDP growth rate in Indonesia, in percent, by industrial origin at constant market prices, 1995-2001

\begin{tabular}{lrrrrrr}
\hline & 1996 & 1997 & 1998 & 1999 & 2000 & 2001 \\
\hline GDP & 7.8 & 4.7 & -13.1 & 0.8 & 4.9 & 3.3 \\
Non-oil GDP & 8.2 & 5.2 & -14.2 & 1.0 & 5.3 & 4.0 \\
$\begin{array}{l}\text { 1. Agriculture, forestry and } \\
\quad \text { fishery }\end{array}$ & 3.1 & 1.0 & -1.3 & 2.2 & 1.7 & 0.6 \\
2. Mining and quarrying & 6.3 & 2.1 & -2.8 & -1.6 & 5.1 & -0.6 \\
3. Manufacturing & 11.6 & 5.3 & -11.4 & 3.9 & 6.1 & 4.3 \\
4. Electricity, gas and water & 13.6 & 12.4 & 3.0 & 8.3 & 8.8 & 8.4 \\
5. Construction & 12.8 & 7.4 & -36.4 & -1.9 & 5.5 & 4.0 \\
6. Trade, hotel and restaurant & 8.2 & 5.8 & -18.2 & -0.1 & 5.6 & 5.1 \\
7. Transportation and & & & & & & \\
$\quad$ communication & 8.7 & 7.0 & -15.1 & -0.8 & 9.4 & 7.5 \\
8. Financial, rentals and & & & & & & \\
$\quad$ business services & 6.0 & 5.9 & -26.6 & -7.2 & 4.3 & 3.0 \\
9. Services & 3.4 & 3.6 & -3.8 & 1.9 & 2.2 & 2.0 \\
\hline
\end{tabular}

Source: World Bank (2003).

collapse to affect any significant market-oriented economy in decades (Evans 1998). At its peak in 1998, the crisis was felt in all sectors of the economy. With the exception of the electricity, gas and water industries, all industries experienced contraction. The four pillars of the economy, namely the manufacturing, the construction, the financial, and the trade, hotel and restaurant sectors, experienced a sharp decline in output. As expected, the financial services were among the worst hit industries.

A modest recovery was reported in various industries in 1999, with the overall GDP growth rate reported at less than 1 percent. From the numbers reported in Table 4.2, it is clear, however, that the financial sector remained the worst affected sector in the economy. By 1999, the output of the banking sector, in particular, was only around 50 percent of its level at the end of 1997. Reflecting the painfully slow progress in the restructuring of the banking industry, the output by the banking industry grew very modestly in 2000 and 2001 , by less than 5 percent per annum.

\section{Investment and private consumption: the contrasting facts of the crisis}

From the expenditure side of the gross domestic product (GDP), it is clear that the economy was experiencing a severe fall in investment (Table 4.3). Private consumption, on the other hand, emerged as the driving force of the economic recovery since 1999. It was the only category on the expenditure side that had in fact reported a positive growth rate from the level reported in 1997. After showing a significant drop of around 6 percent in 1998, the household consumption level managed to grow 


\section{Interest rates and banking reform in Indonesia}

Table 4.3 GDP growth rate in Indonesia, in percent, by expenditure category at constant market prices, 1995-2001

\begin{tabular}{lrrrrrr}
\hline & 1996 & 1997 & 1998 & 1999 & 2000 & 2001 \\
\hline GDP & 7.8 & 4.7 & -13.1 & 0.8 & 4.9 & 3.3 \\
Private consumption & 19.1 & 7.8 & -6.2 & 4.6 & 3.6 & 5.9 \\
Government consumption & 0.7 & 0.1 & -15.4 & 0.7 & 6.5 & 8.2 \\
Gross fixed investment & 12.9 & 8.6 & -33.0 & -19.4 & 23.7 & 4.0 \\
$\begin{array}{l}\text { Exports of goods and } \\
\quad \text { non-factor services }\end{array}$ & 9.1 & 7.8 & 11.2 & -31.8 & 26.1 & 1.9 \\
$\quad \begin{array}{l}\text { Imports of goods and } \\
\quad \text { non-factor services }\end{array}$ & 17.2 & 14.7 & -5.3 & -40.7 & 21.1 & 8.1 \\
\hline
\end{tabular}

Source: World Bank (2003).

annually between 4 and 6 percent in 1999-2001. On average, the household consumption contributed at least around 70 percent of the total GDP in 1999, 2000 and 2001, compared to only around 60 percent of the total GDP in 1995 and 1996. By 2001, the level of household consumption had increased by about 8 percent from its level in 1997 .

In contrast, the gross fixed investment contributed on average less than 20 percent of GDP in 1999-2001, a significant decline from its 30 percent average annual share of the GDP in 1995 and 1996. The level of gross fixed investments declined by about 30 percent in 1998, and 19 percent in 1999. By the end of 2001, the gross investment level was less than 70 percent of the level reported in 1997. The decline in investments and the collapse of the financial sector resulted in a dramatic contraction of the trade figures, by at least 30 percent in 1999.

Even by the end of 2001, there were few domestic and local investors (World Bank 2003). More importantly, a gloomy investment climate has been reported in the manufacturing sector since the outbreak of the financial crisis. Corruption, bureaucratic inefficiency, poor tax and customs administration, labor tensions, decentralization, and inexperienced local governments were some of the key factors contributing to the deteriorating investment climate in Indonesia (World Bank 2003). The small number of investments indicates that the much-needed realized capital or investment in the economy will likely remain very modest in the near future.

\section{Mounting domestic and external debt overhang}

The accumulations of both domestic and external debts have reached dangerous levels since 1998 (Bank of Indonesia Database, Indonesia Central Bureau of Statistics, World Bank 2003). With the collapse of the corporate and financial sectors, the government has been borrowing 
heavily to finance the restructuring of those industries and at the same time to stimulate the economy. Most of the foreign debt accumulated by the government during the post-crisis period has been used to cover the routine deficit, to finance development projects, and to provide loans to state-owned enterprises. By the end of 2000, the government external debt amounted to over 70 percent of the country's total external debt, and close to 80 percent of the GDP. In contrast, the external debt of the government in 1996 was less than 40 percent of the country's GDP.

At its peak in 1998, the external debt-to-GDP ratio (or the vulnerability ratio) reached well over 120 percent, a significant rise from the rate of less than 60 percent in 1996. After 1997, the ratio has been averaging well over the 80 percent "high risk" threshold of the debt-to-GDP ratio (World Bank 2003). The total external debt has declined in 2000 and 2001, but the external vulnerability ratio remains well above 90 percent of the GDP.

A similar assessment can be made for the domestic debt. The domestic debt has reached well over Rp650 trillion, roughly around 50 percent of GDP in 2000. As will be elaborated further, around 65 percent of the domestic debt comprised bonds issued to recapitalize banks that became insolvent during the crisis. Although the domestic debt-to-GDP ratio declined marginally in 2001 from its level in 2000, the nominal value has risen since 1999.

\section{Brief notes on financing bank restructuring in Indonesia ${ }^{5}$}

By the end of 2001, IBRA was reported to have received the assets of restructured banks with a face value of roughly Rp550 trillion, or around 43 percent of the country's GDP in 2000 (IMF 2002). Receipts from the management and disposal of the asset sales will help to offset the Rp650 trillion in public sector debt issued towards recapitalizing the state and private banks.

Out of this total amount of domestic bonds issued, approximately Rp435 trillion was in the form of bank recapitalization bonds (Table 4.4). Roughly around 65 percent of the total recapitalized bonds were spent to deal with bad loans in the state banks, whereas only about 4 percent were channelled to the private banks. Furthermore, it is important to note that almost 70 percent of the total recapitalized bonds were disbursed into the 11 main domestic banks (four state banks and seven private banks) (Table 4.5). Interest payments on these bonds continue to rise and impose a heavy burden on the government budget. For instance, about 20 percent of the total revenue posted in the 2002 budget had to be allocated for the interest payment of the bonds.

In addition to financing the bonds, the government of Indonesia had also committed itself, on 27 January 1998, to provide "a blanket guarantee" on all deposits and liabilities of national banks (other than shareholders' funds and subordinated debt) for an initial period of two years. This 
78 Interest rates and banking reform in Indonesia

Table 4.4 Recapitalized bonds in Indonesia, at the end of 2001 (Rp trillion)

\begin{tabular}{lccccc}
\hline & Total bonds $\begin{array}{l}\text { Percentage } \\
\text { of total }\end{array}$ & Fixed rate & $\begin{array}{l}\text { Variable } \\
\text { rate }\end{array}$ & Hedge \\
\hline Recapitalized bonds & 435.38 & 100.00 & 180.90 & 219.48 & 35.0 \\
State banks (4) & 282.1 & 64.79 & 127.1 & 120.01 & 35.0 \\
Private banks (7) & 17.68 & 4.06 & 3.33 & 14.35 & \\
Others & 135.6 & 31.15 & 50.47 & 85.12 & \\
\hline
\end{tabular}

Source: Bank of Indonesia Database.

Note

Others include private banks being taken over by the government, and regional development banks.

Table 4.5 Eleven main recapitalized banks in Indonesia, bonds and total assets, at the end of 2000 (Rp trillion)

\begin{tabular}{lrrl}
\hline Banks & Assets & Bonds & Ratio(\%) \\
\hline State banks & & & \\
$\quad$ Mandiri & 232.6 & 181.2 & 78 \\
BNI & 114.3 & 61.8 & 54 \\
BRI & 54.0 & 29.1 & 54 \\
BTN & 20.5 & 9.8 & 48 \\
Private banks & & & \\
BCA & 96.9 & 59.6 & 62 \\
Danamon & 60.5 & 47.5 & 79 \\
Niaga & 17.6 & 9.5 & 54 \\
BII & 40.1 & 6.5 & 16 \\
Lippo & 21.8 & 6.0 & 28 \\
Bali & 5.7 & 5.3 & 94 \\
Universal & 11.3 & 4.2 & 37 \\
\hline
\end{tabular}

Source: Bank of Indonesia Database.

Note

The ratio captures the percentage share of the bonds on the overall assets of the banks.

measure had to be taken to deal with depositor panic and international banks not accepting letters of credit issued by Indonesian banks. The provision of this high-cost policy, however, went beyond the initial two-year target. Only in August 2002 did the government reveal its plan to phase out the blanket guarantees (Citibank and Solomon Smith Barney 2002). 


\section{Base money, exchange rate and interest rate}

\section{Base money}

On 1 November 1997, the day after the signing of the first IMF agreement, the government of Indonesia announced the liquidation of 16 banks. Although this had been foreshadowed, the decision created shock waves that resulted in a total loss of confidence in the Indonesian banking system (Soesastro and Basri 1998). One of the aftermaths of the closure of the banks was the rise in the levels of monetary aggregates during the last few months of 1997 and first seven months of 1998. The expansion reflected the liquidity support provided to troubled banks and the impact of depositor runs on banks. The consequence of the banking sector bailouts prompted an increasing use of seigniorage, and would eventually require infusions of liquidity to prevent systemic runs.

Within a month after the announcement of the closures of the 16 banks, the level of base money had grown by more than 36 percent. By the end of July 1998, the base money had experienced an unprecedented increase of more than 115 percent from its level in November 1997 (Bank of Indonesia Database). For the sake of comparison, between 1991 and 1996, the annual growth rate of base money in Indonesia had been averaging around 25 percent, with the highest growth in 1996 at 38 percent and the lowest in 1991 at around 15 percent.

\section{Rupiah: to float or not to float}

In August 1997, the monetary authority of Indonesia floated the rupiah and immediately the Indonesian currency experienced a 16.8 percent depreciation against the US dollar (Figure 4.1). However, the worst fall occurred only in the first six months of 1998. Right after being floated in August 1997, the nominal exchange rate was at Rp3,035 per 1US dollar. By June 1998, the local currency was traded at 1US dollar for Rp14,900. Corsetti et al. (1999) argue that the nominal depreciations of Asian currencies in 1997 were in fact consistent with the expected inflationary consequences of banking and financial bailouts.

In addition to the massive depreciation, the uncertainty and the volatility of the rupiah had further worsened the economic conditions during the crisis. The spread between the buying and the selling rate of rupiah against the US dollar had widened from Rp100 during the first few months of 1997 to more than Rp1,500 in February 1998, reflecting the rise in the risk premium for holding rupiah (Central Bureau of Statistics). Despite the return of political stability in late 2001, the spread rate continued to be wider than the pre-crisis rate.

Another most commonly used measurement to evaluate the uncertainties in the foreign exchange market is the volatility index. To estimate the 


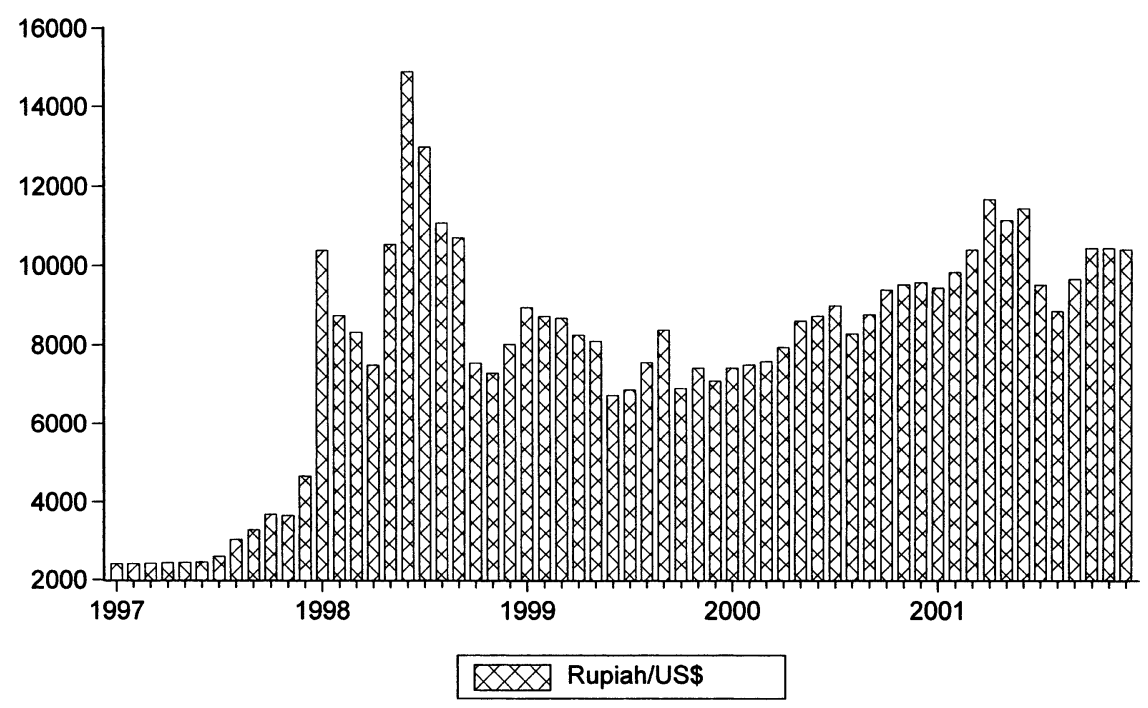

Figure 4.1 Nominal exchange rate of Indonesian rupiah against the US dollar, January 1997 to December 2001 (source: IMF (various years), International Financial Statistics.)

volatility rates of the rupiah, we employ different types of ARCH models. The GARCH specification that we consider takes the form:

$$
\begin{aligned}
& \ln N E R_{t}=a_{0}+a_{1} \ln N E R_{t-1}+e_{t}, \text { where: } e_{t} \sim N\left(0, h_{t}\right) \\
& h_{t}=\alpha+\beta e_{t-1}^{2}+\gamma h_{t-1}+u_{t} .
\end{aligned}
$$

$\left(L n N E R_{t}\right)$ is the nominal exchange rate of rupiah against the US dollar in $\log$ form. The conditional variance equation, equation (2) described above, is a function of three terms: (1) the mean $\alpha$; (2) news about volatility from the previous period, measured as the lag of the squared residual from the mean equation: $e_{t-1}^{2}$ (the ARCH term); and (3) the last periods forecast error variance, $h_{t-1}$ (the GARCH term). The test is done on daily rupiah rates from 1 August 1997 to 12 June 2002.

Different types of ARCH models, such as ARCH, GARCH and EGARCH models, were estimated on the data. However, the GARCH $(1,1)$ models are found to be superior in generating the volatility for the rupiah nominal exchange rates against the US dollar. ${ }^{6}$ Consistent with the risk premiums captured by the spread between the buying and the selling rate of rupiah against the US dollar, we find a sharp rise in the volatility rate of the rupiah, particularly in 1998 (Figure 4.2). The average volatility rate from January 1998 to July 1998 was more than four times higher than the 


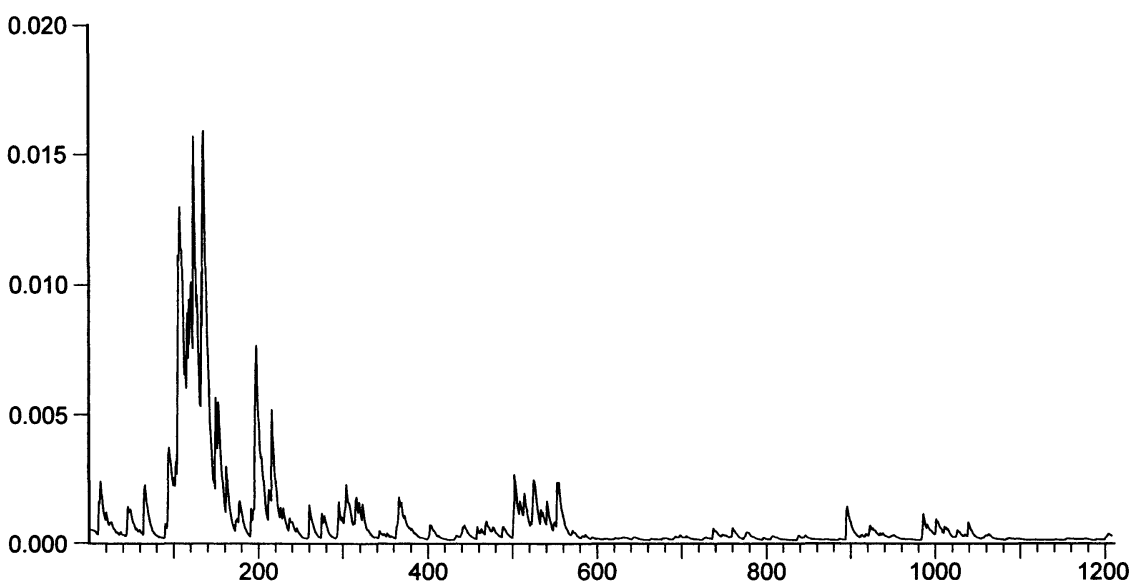

Figure 4.2 GARCH(1,1) volatility rate of Indonesian rupiah against the US dollar, daily observations, 1 August 1997 to 12 June 2002. (Note: The horizontal axis represents the daily observation of the exchange rate, starting 1 August 1997 until 12 June 2002. The results are based on the author's own calculations.)

average from August 1997 to December 1997. The GARCH(1,1) conditional variance also shows that the volatility rate declined substantially starting in 1999. From January 2000 to June 2002, the average volatility rate was only one-quarter of the rate from August 1997 to December 1997. Our test results are consistent with those of McKinnon (2000) and Hernandez and Montiel (2001). Both of these studies have found that after a brief adoption of a floating regime in late 1997 and early 1998, most of the East Asian crisis-affected economies, including Indonesia, have either gone back to the old regime of a soft-US dollar pegged policy, or sought to stabilize the values of their currencies against the US dollar without adopting any of the strong commitment mechanisms, a strategy known as the "hollow middle".

\section{One-month certificate of Bank of Indonesia Rate}

As briefly stated in the introduction, one of the big debates on the role of monetary policy in Indonesia during the crisis period has centered on the desirability of increasing key interest rates to defend the local currency and to manage the growth rate of the base money. At its highest level reported in August 1998, the one-month central bank security (1-month SBI) rate went beyond 70 percent (Figure 4.3). Even by the end of 1998, the 1-month SBI rate was still hovering at more than 25 percent. Between June 1999 and April 2000, the 1-month SBI rate reported a steady decline and reached its lowest rate at around 11 percent in April 2000. However, 


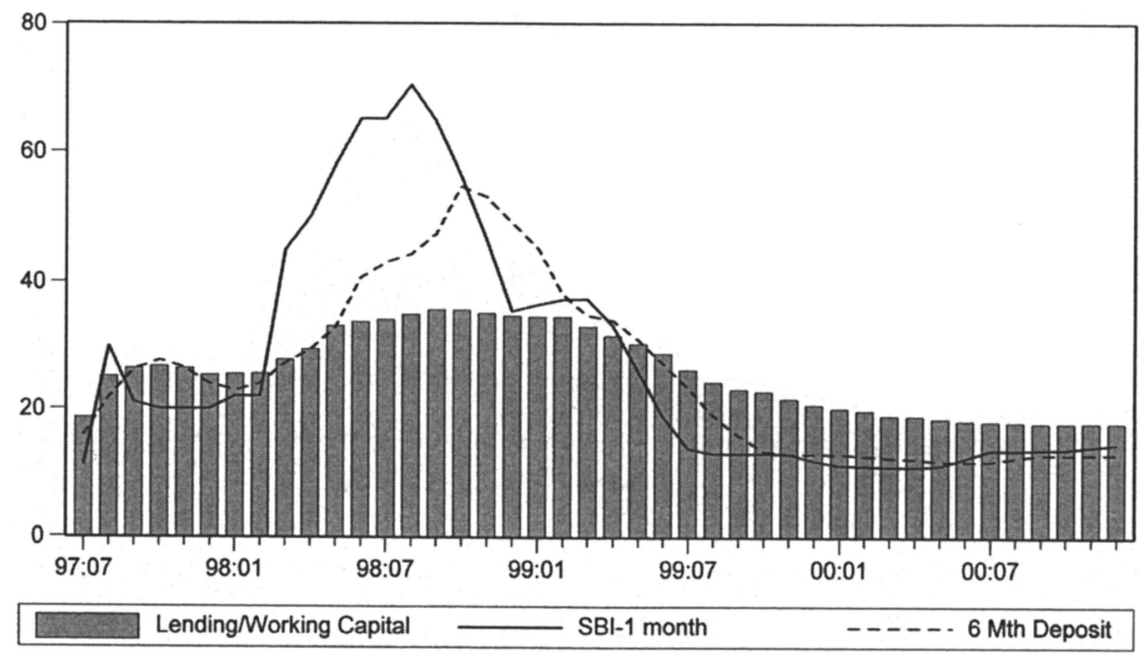

Figure 4.3 Interest rate spread (working capital rate and 6-month deposit rate), and the SBI-1 month rate in Indonesia, July 1997 to December 2000 (source: IMF (various years), International Financial Statistics; Bank Indonesia Database.)

the rate has reverted back to a rising trend starting in June 2000. In the last six months of 2001, the 1-month SBI rate has reached an average level of well above 17 percent.

\section{Empirics}

The objective of this section is to examine the relationships between the interest rate and the other two key monetary indicators, the exchange rate and the base money. Given the macroeconomic variables discussed above, there is clearly a potential for double causality. In other words, one needs to investigate a two-way interaction between the relevant variables. ${ }^{7}$ To achieve this, we make use of the conventional Granger-causality tests to ascertain the direction of causation. While our interest is in whether rupiah movements and the growth rate of base money are influenced by the changes in the key central bank interest rate, we also examine bidirectional Granger-causation for completeness. A general specification of our test in the bi-variate context $(\mathrm{X}, \mathrm{Y})$ may be expressed as:

$$
\begin{aligned}
& \Delta Y_{t}=\Sigma_{i=1} \alpha_{1 i} \Delta Y_{t-i}+\Sigma_{i=1} \beta_{1 i} \Delta X_{t-i}+\epsilon_{1 t} \\
& \Delta X_{t}=\Sigma_{i=1} \alpha_{2 i} \Delta Y_{t-i}+\Sigma_{i=1} \beta_{2 i} \Delta X_{t-i}+\epsilon_{2 t}
\end{aligned}
$$

where $\epsilon_{t}$ is a white noise error term and $\Delta$ is the first difference operator. 
All variables are in log form. The Granger-causality test examines the statistical significance of the $\Delta X_{t}$ in explaining $\Delta Y_{t}$ in equation (3) and viceversa in equation (4). To ensure the appropriateness of the Granger-causality test, we investigate the unit-root properties of all three monetary variables. We find that all of them are an I(1) series. ${ }^{8}$

\section{Exchange rate and interest rate}

Two contrasting sets of views have emerged on the effectiveness of the interest rate policy as a stabilization tool for the domestic currency. The traditional view argues that a tight monetary policy is necessary to support the exchange rate. A rise in the interest rate raises the returns that an investor obtains from investing in the country, reduces capital flight and discourages speculation. In contrast, the revisionist view claims that under the unique conditions of a financial panic, tight monetary policies and high interest rates would result in capital outflows and exchange rate depreciation. That is, a high interest rate causes a financial implosion, and raises default possibilities, thus weakening the currency (Furman and Stiglitz 1998, Radelet and Sachs 1998).

Applying the Granger-causality test, as shown in equations (3) and (4), we investigate the effectiveness of the changes in the 1-month SBI rate in stabilizing the fluctuations of the local currency. As discussed before, the Central Bank of Indonesia had actively tried to defend the rupiah by raising its SBI rates. Given the availability of daily data on both the rupiah and the 1-month SBI rate, we could break our observations into three sets: (1) the entire period, August 1997 to June 2002; (2) the peak of the crisis period, August 1997 to December 1999; and (3) the post-crisis period, January 2000 to June 2002.

The results of our tests are posted in Table 4.6. Three sets of lags were tested ( 5 days, 15 days and 30 days).$^{9}$ For the entire sample period and the peak of the crisis period, the test statistics clearly indicate that the changes in the SBI interest rate did not have any significant influence on the fluctuations of the rupiah. The F-statistics arrive at the same conclusion using all three different lags. As for the post-crisis period, we found evidence that the interest rate policy had a significant influence (at 10 percent significance level) on the fluctuations of the rupiah for the 30 days lag. However, the results are not as conclusive as they varied when we tried different sets of lags. In fact, when we used the 5 days lag and the 15 days lag, we found the interest rate to be an insignificant factor. In short, the interest rate policy had failed to stabilize the local currency during the crisis. This finding supports the conclusion of Azis (2001). ${ }^{10}$

Interestingly, the results have also shown that for the entire period, and for the peak of the crisis period, the changes in the rupiah have significant Granger-caused movements in the 1-month SBI rate. These findings 


\section{Interest rates and banking reform in Indonesia}

Table 4.6 Granger-causality test, rupiah and 1-month SBI rate

1. Entire period: daily observations, August 1997 to June 2002

\begin{tabular}{llll}
\hline Null hypothesis & Observation & F-Statistics & Probability \\
\hline $\begin{array}{c}\Delta \text { InSBI doesn't } \\
\text { Granger-cause }\end{array}$ & 1260 (lags $=30)$ & 0.9104 & 0.6064 \\
$\begin{array}{c}\Delta \text { lnrupiah } \\
\Delta \text { lnrupiah doesn't } \\
\text { Granger-cause }\end{array}$ & $1260($ lags $=30)$ & 5.4598 & 0.0000 \\
$\Delta$ lnSBI & & & \\
\hline
\end{tabular}

2. Peak of the crisis: daily observations, August 1997 to December 1999

\begin{tabular}{llll}
\hline Null hypothesis & Observation & F-Statistics & Probability \\
\hline $\begin{array}{c}\Delta \text { lnSBI doesn't } \\
\text { Granger-cause }\end{array}$ & 580 (lags $=30)$ & 0.4886 & 0.9905 \\
$\begin{array}{c}\Delta \text { lnrupiah } \\
\begin{array}{c}\Delta \text { lnrupiah doesn't } \\
\text { Granger-cause } \\
\Delta \operatorname{lnSBI}\end{array}\end{array}$ & $580($ lags $=30)$ & 2.7223 & 0.0000 \\
\hline
\end{tabular}

3. Post-crisis: daily observations, January 2000 to June 2002

\begin{tabular}{llll}
\hline Null hypothesis & Observation & F-Statistics & Probability \\
\hline $\begin{array}{c}\Delta \text { lnSBI doesn't } \\
\text { Granger-cause }\end{array}$ & $630($ lags $=30)$ & 1.3958 & 0.0807 \\
$\begin{array}{c}\Delta \text { lnrupiah } \\
\begin{array}{c}\Delta \text { lnrupiah doesn't } \\
\text { Granger-cause } \\
\Delta \operatorname{lnSBI}\end{array}\end{array}$ & $630($ lags $=30)$ & 1.1891 & 0.2269 \\
\hline
\end{tabular}

Notes

All variables are in the $\log$ form $(\ln ) ; \Delta$ is the first difference operator.

captured the policy response implemented by the Indonesian monetary authorities to defend the local currency with the interest rate policy.

\section{Interest rate and base money}

Another set of the Granger-causality test was conducted to evaluate the effectiveness of the interest rate policy in absorbing the excess base money in Indonesia. However, given that only monthly data were available, we did not have a large enough degree of freedom to break down the observation set into three sub-periods as we did previously. The test results on the entire sample covering the period of August 1997 to December 2001 confirmed the ineffectiveness of the interest rate policy as a key instru- 
Table 4.7 Granger-causality test, base money (M0) and 1-month SBI rate

\begin{tabular}{|c|c|c|c|}
\hline \multicolumn{4}{|c|}{ Entire period: monthly observations, August 1997 to December 2001} \\
\hline Null hypothesis & Observation & F-Statistics & Probability \\
\hline $\begin{array}{l}\Delta \text { lnM0 doesn't } \\
\text { Granger-cause }\end{array}$ & $55($ lags $=3)$ & 2.0777 & 0.1161 \\
\hline \multicolumn{4}{|l|}{$\Delta \operatorname{lnSBI}$} \\
\hline $\begin{array}{l}\Delta \operatorname{lnSBI} \text { doesn't } \\
\text { Granger-cause }\end{array}$ & 55 (lags $=3)$ & 1.3502 & 0.2698 \\
\hline$\Delta \ln M 0$ & & & \\
\hline
\end{tabular}

Notes

All variables are in the $\log$ form $(\ln ) ; \Delta$ is the first difference operator.

ment for reducing the base money growth rate (Table 4.7). No significant F-statistics were reported to indicate any Granger-causality relationships between the interest rate and the base money.

\section{Bank restructuring and high interest rate}

The preceding empirical results have convincingly shown that the active monetary policy intervention in the foreign exchange market and in the money market through various changes in the key SBI rates has not been effective in achieving its targets. Obviously, one must acknowledge other factors that may explain the ineffectiveness of the interest policy, especially as a measure to stabilize the rupiah. Political instability and social unrest, for instance, have also been blamed for the high volatility of the rupiah, particularly during the height of the crisis. However, despite the ineffectiveness of the interest rate policy, the policy of maintaining a high interest rate lasted for most of the crisis period. The next sub-section will review some indicators to show the negative implications of the high interest rate on the general performance of the local banks.

\section{Interest rate spread and profitability}

Looking at Figure 4.3, it is apparent that the six-month deposit rate follows the movement of the 1-month SBI rate more closely than the lending rate. The Granger-causality tests confirm these visual observations (Table 4.8). Changes in the SBI rate had significantly Granger-caused both the lending rate and the deposit rate during the period August 1997 to December 2000. But it is clear from the F-statistics that the causality effect of the SBI rate is significantly stronger on the deposit rate than on the lending rate. ${ }^{11}$ The combination of high inflationary pressures and the rising SBI rate caused the deposit rate to increase proportionally, ensuring 


\section{Interest rates and banking reform in Indonesia}

Table 4.8 Granger-causality test, 1-month SBI rate, 6-month deposit rate and lending rate

Entire period: monthly observations, August 1997 to December 2001

\begin{tabular}{|c|c|c|c|}
\hline Null hypothesis & Observation & F-Statistics & Probability \\
\hline $\begin{array}{l}\Delta \operatorname{lnDeposit} \text { doesn't } \\
\text { Granger-cause } \\
\Delta \operatorname{lnSBI}\end{array}$ & $41(\operatorname{lags}=3)$ & 0.1869 & 0.9048 \\
\hline $\begin{array}{l}\Delta \operatorname{lnSBI} \text { doesn't } \\
\text { Granger-cause } \\
\Delta \operatorname{lnDeposit}\end{array}$ & $41($ lags $=3)$ & 11.4148 & 0.0000 \\
\hline $\begin{array}{l}\Delta \operatorname{lnLending~doesn't~} \\
\text { Granger-cause } \\
\Delta \operatorname{lnSBI}\end{array}$ & $41($ lags $=3)$ & 0.0102 & 0.9985 \\
\hline $\begin{array}{l}\Delta \operatorname{lnSBI} \text { doesn't } \\
\text { Granger-cause } \\
\Delta \operatorname{lnLending}\end{array}$ & $41($ lags $=3)$ & 3.5617 & 0.0253 \\
\hline
\end{tabular}

Notes

All variables are in the $\log$ form $(\ln ) ; \Delta$ is the first difference operator.

that the real interest rate was marginally above zero, and preventing massive withdrawals of deposits and conversions of rupiah to foreign currencies, particularly during the height of the crisis. The lending or working capital rate, on the other hand, could not rise as much to prevent further defaults on the loans. In particular, the greater uncertainty and the bankruptcies in the key industries had caused a sharp decrease in the demand for working capital by the end of 1998 .

Consequently, as the deposit rate exceeded the lending rate in early 1998, the domestic banking sector in Indonesia experienced a costly period of negative-interest rate spreads (Figure 4.3). ${ }^{12}$ The rise in the deposit rate implied a rising cost for the bank, whereas a higher lending rate meant an increasing interest return for the banks. From January 1998 to December 1998, the six-month deposit rate was on average around 7 percent higher than the lending rate. In October 1998, the negative spread was at a staggering 19 percent. The negative spread continued during the first seven months of 1999, with the average spread rate of 2.2 percent.

In turn, the negative spread further deteriorated the performance of the banking sector. Overall, the banking industry in Indonesia experienced a total gross loss of as much as Rp178 trillion by December 1998 (Figure 4.4). ${ }^{13}$ Consistent with the end of negative spread rates in early 2000 , the banking industry started to post positive gross profits in 2000 and 2001. Reflecting the improvement in the profitability of the banking industry, the percentage of the gross non-performing loans over the total loans of the banking sector improved to the level of 18 percent at the end 


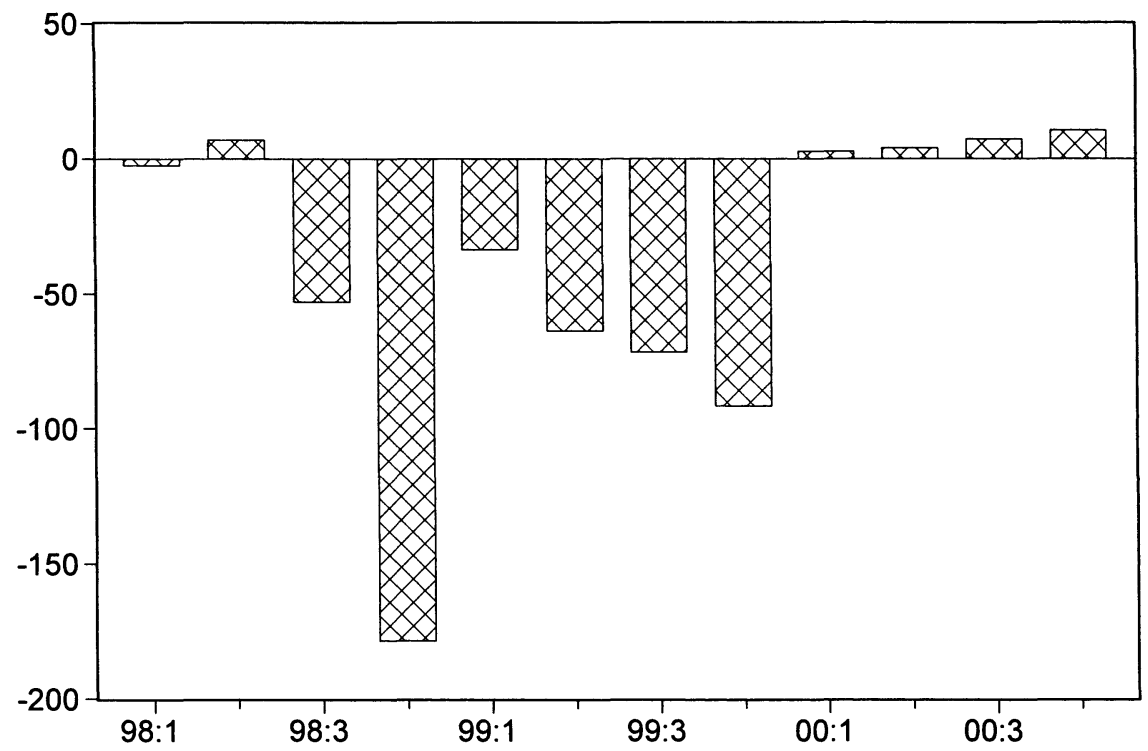

Figure 4.4 Banking industry in Indonesia, profits before tax (Rp trillion) (source: Bank of Indonesia Database.)

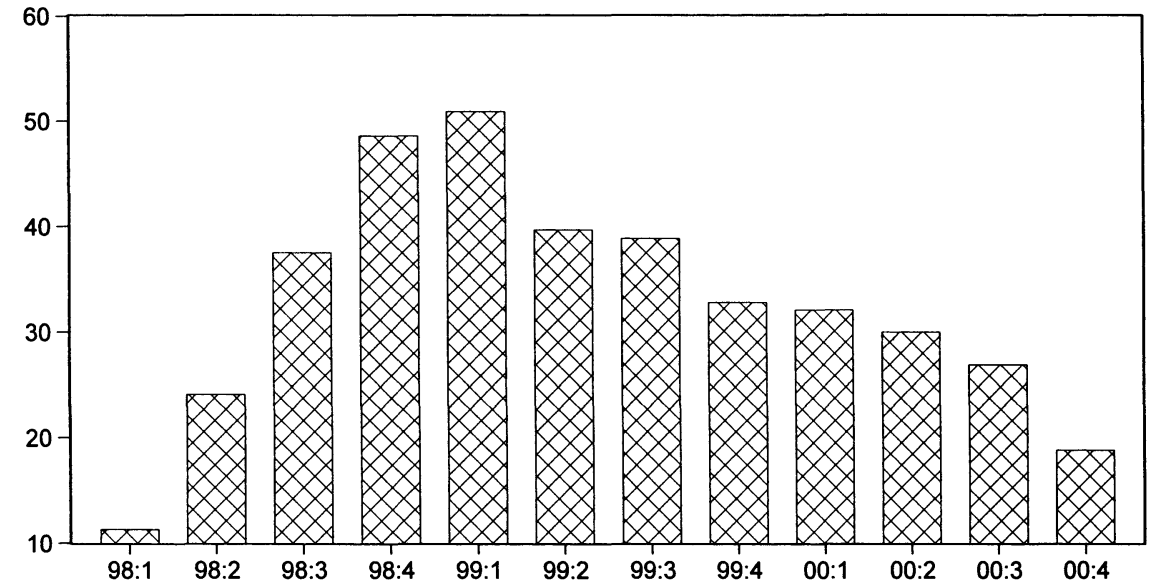

Figure 4.5 Gross non-performing loans in Indonesia, in percent of total loans (source: Bank of Indonesia Database.) 
of 2000 , from the worst level of 50 percent reported between December 1998 and March 1999 (Figure 4.5). ${ }^{14}$

\section{Conclusion}

Given the problems and the level of corporate distress, as well as the continued lack of good governance over the process, the recovery of the banking and corporate sectors, and therefore the recovery of the East Asian economies, will take more time (Claessens et al. 1999). As briefly discussed, previous papers have highlighted other factors responsible for the slow progress in the restructuring of the problem banks in Indonesia. This study evaluated the monetary policy adopted by the Indonesian government, and found that the high interest rate policy in particular hampered the progress of the bank restructuring process.

The empirics suggest that the high interest rate policy was an ineffective monetary instrument in dealing with both the volatile local currency and the rapid growth of base money, particularly during the height of the financial crisis in 1998 and 1999. Furthermore, the high interest rate policy was responsible for the negative interest spread that had partly caused the overall banking sector to experience a negative profit. From the experience of Indonesia, it is clear that for monetary policy to be an effective recovery instrument, it must consider and incorporate other macroeconomic objectives of the country, as well as take into account the fragility of the banking and corporate sectors.

\section{Notes}

1 The author thanks Anton H. Gunawan for his insightful comments on various issues and also for his valuable updated data series.

2 The first three Letters of Intent (LOIs) between the government of Indonesia and the International Monetary Fund were signed in October 1997, January 1998 and March 1998.

3 As of the end of 2001, IBRA's chairmanship has been changed at least seven times since its establishment in 1998.

4 For cases brought by IBRA against the top 21 obligors, as of mid-February 2002, IBRA had won 7 out of 25 cases in the bankruptcy court, and none of the four cases in the civil court (IMF 2002: 42).

5 Numerous studies and reports have highlighted the details of the restructuring process of the banking sector in Indonesia, such as Johnson (1998), McLeod (2000), Enoch et al. (2001) and Pangestu and Habir (2002), to name a few. Given those early studies, this section will only summarize a few key policies. The objective of this section is to highlight the heavy cost of the restructuring programs undertaken by Indonesia.

6 The $\operatorname{GARCH}(1,1)$ test results are available upon request to the author.

7 For instance, the changes in the domestic interest rate may influence the movements of the rupiah, and reciprocally, the fluctuations in the domestic currency could have been a major reason behind the changes in the domestic interest rate. 
8 For the sake of brevity, the Augmented Dickey-Fuller unit-root test results are not posted in the chapter. However, they are available upon request to the author.

9 These numbers of lags were chosen to ensure that we have enough degrees of freedom. We experimented with other lags, but the results did not change. For reporting purposes, we only show the results of the 30 days lag.

10 Azis (2001) shows that the effectiveness of the interest rate policy depends on the economic and political risk factors in Indonesia during the 1997 financial crisis. When the country was facing a politically turbulent period, the rising interest rates only led to further depreciation of companies' values and investments, and triggered greater expectations of a further weakening of the local currency.

11 We applied three different lags, 1, 2 and 3 months, but the overall conclusions are the same.

12 The negative spread is calculated by subtracting the deposit rate from the lending rate.

13 Given the nominal exchange rate at an average of $1 \mathrm{US} \$=\mathrm{Rp} 7,600$ for the month of December 1998, this implies that the banking sector was experiencing a total loss of around US $\$ 23.4$ billion.

14 Given the limited sample observations, and hence degrees of freedom, for the gross profit number and the non-performing loans, we cannot run any regression tests to statistically show that the negative spread in the interest rate has significantly influenced the performance of the banks.

\section{References}

Azis, I. (2001) "Modelling crisis evolution and counterfactual policy simulations: a country case study", Asian Development Bank Institute Working Paper No. 23.

Bank of Indonesia. Database. Online. Available at: <http://www.bi.gov.id > (accessed 15 August 2003).

Bhagwati, J. (1998) "The difference between trade and widgets and dollars", Foreign Affairs, 77(3): 7-12.

Central Bureau of Statistics, Indonesia.

CEIC. Database, Hong Kong.

Citibank and Solomon Smith Barney (2002) Indonesian Rupiah Bond Weekly, 7 August 2002.

Claessens, S., Djankov, S. and Klingebiel, D. (1999) "Financial restructuring in East Asia: halfway there?", Financial Sector Discussion Paper 3, Washington, D.C.: The World Bank.

Corsetti, G., Pesenti, P. and Roubini, N. (1999) "What caused the Asian currency and financial crisis?", Japan and the World Economy, 11: 305-373.

Enoch, G., Baldwin, B., Frecaut, O. and Kovanen, A. (2001) "Indonesia: anatomy of a banking crisis, two years of living dangerously 1997-1999”, IMF Working Paper/01/52, International Monetary Fund, Washington, D.C.

Evans, K. (1998) "Survey of recent developments", Bulletin of Indonesian Economic Studies, 34(3): 5-36.

Furman, J. and Stiglitz, J.E. (1998) "Economic crises: evidence and insights from East Asia”, Brookings Papers on Economic Activity, 2, Washington, D.C.: Brookings Institution.

Hernandez, L. and Montiel, P. (2001) "Post-crisis exchange rate policy in five 


\section{Interest rates and banking reform in Indonesia}

Asian countries: filling in the 'hollow middle'?", IMF Working Paper/01/170, International Monetary Fund, Washington, D.C.

IMF (2002) "Indonesia: selected issues", IMF Country Report, 02/154, Washington, D.C.: International Monetary Fund.

— (various years) International Financial Statistics, Washington, D.C.: International Monetary Fund.

Johnson, C. (1998) "Survey of recent developments", Bulletin of Indonesian Economic Studies, 34(2): 3-60.

Kawai, M. (2002) "Bank and corporate restructuring in crisis-affected East Asia: from systemic collapse to reconstruction", in G. de Brouwer (ed.) Financial Markets and Policies in East Asia, London: Routledge.

McKinnon, R. (2000) "The East Asian dollar standard, life after death", Economic Notes, 29.

McLeod, R. (2000) "Survey of recent developments", Bulletin of Indonesian Economic Studies, 36(2): 5-41.

Pangestu, M. and Habir, M. (2002) "The boom, bust and restructuring of Indonesian banks", in G. de Brouwer (ed.) Financial Markets and Policies in East Asia, London: Routledge.

Radelet, S. and Sachs, J.D. (1998) "The East Asian financial crisis: diagnosis, remedies, prospects”, Brookings Papers on Economic Activity, 1, Washington, D.C.: Brookings Institution.

Rajan, R. and Siregar, R. (n.d.) "Private capital flows in East Asia: boom, bust and beyond", in G. de Brouwer (ed.) Financial Markets and Policies in East Asia, London: Routledge.

Siregar, R. (2003) "Interest spreads and mandatory credit allocations: implications on bank loans to small businesses in Indonesia." Mimeo, Department of Economics, Adelaide University.

Siregar, R. and Rajaguru, G. (n.d.) "Base money and exchange rate: sources of inflation in Indonesia during the post-1997 financial crisis", Journal of Economic Integration (forthcoming).

Soesastro, H. and Basri, M.C. (1998) "Survey of recent developments", Bulletin of Indonesian Economic Studies, 34(1): 3-54.

World Bank (2003) "Indonesia maintaining stability, deepening reforms", Report No. 25330-IND, Washington, D.C.: The World Bank. 


\title{
5 Crisis, social sector and income distribution in Singapore and Thailand
}

\author{
Pundarik Mukhopadhaya
}

\section{Introduction}

A vast body of literature is now available on the post mortem of the financial crisis that hit East Asian economies during 1997-1998. ${ }^{1}$ The economic slump caused by the crisis has caused widespread social distress in the worst-affected countries, Thailand, Indonesia and the Philippines, and even the least affected countries, such as Singapore, also experienced a reduction in the government expenditure on various social sectors. A fall in output and incomes was invariably accompanied by massive job losses, due to bankruptcies and cutbacks in the production sectors. This led to a sharp rise in unemployment, fuelled by the rise in inflation which exerted a further toll on real wages and incomes. The combined effect increased the incidence and severity of absolute poverty and worsened the distribution of income.

The main objective of this chapter is to explore the effect of the financial crisis on the distribution of income and poverty. Two countries are considered for analysis: Singapore, one of the least affected countries, and Thailand, where the crisis started and had a very adverse effect. During the crisis it was feared that economic and financial reversals would impose severe hardship on the social welfare of the populations of the countries concerned. Beyond the employment and wage impacts, it was anticipated that government social programs would be cut back and the prices of key social commodities such as imported medicines would escalate. It was also assumed that families would reduce their expenditures for health and education, and that those services would be beyond reach to a growing number of impoverished families. We will make an effort to analyze briefly the effects of the crisis on the education and health sectors of Singapore and Thailand.

The structure of the chapter is as follows: we will first consider the backgrounds of Singapore and Thailand, then analyze the profile of income inequality and poverty during the crisis in Singapore and Thailand, discuss the effects on the education and health sectors, and examine the various government actions to protect the most vulnerable during the crisis, summarizing in a conclusion. 
92 Income distribution in Singapore and Thailand

\section{Overview of the economy and the social sector: Singapore and Thailand}

Singapore, a city state of a little over three and half million people, recorded the world's ninth highest GNP per capita of US\$29,610 in the list of 174 countries covered in the World Bank (2000/2001). Singapore has been among the fastest growing economies in East Asia. Its average rate of growth (in per capita real GNP) was 6.4 percent during the 1980-1990 period and 8.7 percent during the first half of the 1990s. With the increasing growth in national income, there was a prominent increase in the total labor force in Singapore. Over the span of 25 years from 1970, the labor force almost trebled, the increase in female labor force being the most prominent. The doubling of the female labor force participation rate is a clear indication of increased educational attainment. ${ }^{2}$

Over the past 30 years, real per capita gross domestic product (GDP) tripled in Thailand. Between 1980 and 1995, growth averaged 6.4 percent annually. The rapid growth rate has been accompanied by a steep decline in poverty and an increase in inequality. With rapid economic growth, disparities between urban and rural areas and between well-educated and lesser educated households increased. In 1992, a household whose head had received a basic education at either elementary or junior secondary school was 60 percent less likely to be in poverty than in 1975 (Ablett and Slengesol 2000). If the household head had little or no education, that household was only 38 percent less likely to be in poverty. Life expectancy increased by 12 years to 70 between 1975 and 1998. Illiteracy fell to 6.2 percent of the population in 1995. While Singapore made better progress in the health sector than Thailand, it could not catch up with the latter's high educational expansion rate; thus Singapore's illiteracy rate is higher than that of Thailand.

Looking at Table 5.1, it is quite clear that Singapore enjoys the advantages of a fully urban state and its per capita GDP is almost four times that of Thailand. The World Bank (1993) included both Singapore and Thailand in its list of miraculous economies because of their very high growth rate and low inequality.

Thailand offers a great contrast to Singapore. The land area of Thailand is more than 1,300 times that of Singapore and thus it has great regional diversity. The mean per capita income of Bangkok in 1990-1999 is more than twice that of the Central region and four times that of the Northeast region. However, a decomposition analysis showed that this regional divergence does not have much effect on the income distribution scenario. ${ }^{3}$ It is noted that educational divergence is the main cause of the high income inequality in Thailand. Unlike in Singapore, basic education is free in Thailand and a constitutional right of the Thai people. By investing heavily in the education sector, the Thai government was able to increase the enrollment rate at both the primary and secondary levels of 
Table 5.1 Various indicators in Singapore and Thailand

\begin{tabular}{|c|c|c|}
\hline & Singapore & Thailand \\
\hline Life expectancy at birth (1998) (M; F) & $75 ; 79$ & $70 ; 75$ \\
\hline $\begin{array}{l}\text { Infant mortality rate, per } 1,000 \text { live births } \\
\quad(1980 ; 1997)\end{array}$ & $12 ; 4$ & $49 ; 29$ \\
\hline Adult illiteracy rate $(\mathrm{M} ; \mathrm{F})$ & $4 ; 12$ & $3 ; 7$ \\
\hline $\begin{array}{l}\text { Public education expenditure (\% of GNP) } \\
\quad(1980 ; 1997)\end{array}$ & $2.8 ; 3.0$ & $3.4 ; 4.8$ \\
\hline HDI rank (1997; value) & $22 ; 0.888$ & $67 ; 0.753$ \\
\hline $\begin{array}{l}\text { Average annual growth rate (GNP per capita) } \\
\qquad(1980-1990 ; 1990-1995)^{a}\end{array}$ & $4.7 ; 6.7$ & $5.9 ; 7.5$ \\
\hline Average annual rate of inflation $(1998)^{b}$ & -1.5 & 8.7 \\
\hline $\begin{array}{l}\text { Public expenditure on health (\% of GDP) } \\
\quad(1990-1998)\end{array}$ & 1.1 & 1.3 \\
\hline Total unemployment (\% of labor force) $(1991)^{c}$ & 1.9 & 2.7 \\
\hline Gini coefficient $(1971-1980 ; 1981-1990)^{d}$ & $0.45 ; 0.41$ & $0.37 ; 0.37$ \\
\hline Head-count index $(1975 ; 1985 ; 1993 ; 1995)^{e}$ & Nil & $\begin{array}{l}8.1 ; 10.0 \\
\quad<1.0 ;<1.0\end{array}$ \\
\hline Urban population (\%) & 100 & 20.6 \\
\hline Per capita GDP (1997 US\$ PPP) & 28,460 & 6,690 \\
\hline Illiteracy rate $(1980 ; 1985 ; 1990 ; 1995)(\%)^{f}$ & $\begin{array}{r}17.0 ; 14.3 \\
11.0 ; 8.9\end{array}$ & $\begin{array}{l}12.6 ; 9.8 ; 6.6 \\
\quad 6.2\end{array}$ \\
\hline
\end{tabular}

Sources:

a World Bank (1997, 1999/2000);

b Human Development Report (UNDP 2000);

c World Development Indicator CD ROM (World Bank 2000);

d World Bank (1993);

e Estimated from Ahuja et al. (1997);

f UNESCO Statistical Yearbook, various years; all other variables are taken from World Bank $(2000 / 2001)$

education. ${ }^{4}$ In the decade prior to the crisis, Thailand made remarkable progress in expanding education with the gross enrollment ratio increasing significantly at most levels of education. According to the statistics published by the Office of National Education Commission, near universal enrollment in primary education has been achieved. Gross enrollment ratios at the lower secondary level increased from 40 percent in school year (SY) 1990-1991 to 72 percent in SY 1997-1998. Upper secondary and vocational enrollment ratios almost doubled to 47 percent. With the decline in poverty between 1992 and 1997, the number of school dropouts decreased (ONEC 1999). ${ }^{5}$ The Child and Youth Survey ${ }^{6}$ reveals that over 3 million more pre-primary to secondary school students attended school in 1997 than in 1992.

Poverty is another aspect to be addressed in the case of Thailand. Data from the Socioeconomic Survey (SES) shows a sharp decline of poverty from 1988 to 1996 . The head count ratio declined from 32.6 percent to 11.4 percent, while the poverty gap ratio declined from 10.4 percent to 2.8 


\section{Income distribution in Singapore and Thailand}

percent. ${ }^{7}$ During this period the average income grew very rapidly and the poverty rate decreased due to the high migration rate from poor areas of the Northeast to Bangkok and the Central region, where unskilled and semi-skilled manpower was in great demand in the construction sectors of the rapidly growing cities. As a consequence the school enrollment increased at the primary and the lower secondary level. Education is an important predictor of poverty. In Thailand, the poverty level decreased rapidly owing to the enormous expansion in education.

The regional dimension of poverty in Thailand is extremely pronounced. The Northeast has been the poorest region with 48 percent of the population living below the poverty line in 1988, while in the South there were 33 percent, in the North 32 percent and in the Central region 27 percent. The incidence of poverty was lowest in Bangkok where 6 percent were below the poverty line in 1988; this was further reduced to 1 percent during 1996. For the same year, the percentages of the population living below the poverty line in Northeast, South, North and Central were 19,12, 11 and 6 percent respectively. This shows that the decline in poverty is greater in the more affluent regions. The dimension of rural poverty is quite severe in Thailand. In 1988, 40 percent of the population in the rural areas lived below the poverty line while the corresponding figure for the Sanitary and Municipal areas were 22 percent and 8 percent. Rural poverty decreased to 15 percent in 1996, while only 6 percent and 2 percent in the Sanitary and Municipal areas respectively lived below the poverty line (World Bank 2001). To investigate the reason for the poverty, the World Bank (2001) identified a strong positive correlation between the incidence of poverty and household size, and the relationship was found to become stronger over time. In the 1990s it was found that the incidence of poverty is highest among farm workers, then among farm operators (including tenants), general workers, production and construction workers. The lowest level of poverty was found among professionals, technical staff and managers. There is a slightly higher incidence of poverty among clerical, sales and service workers and among entrepreneurs, trade and industry people. ${ }^{8}$

Let us now provide a brief account of the pattern of the government expenditure on social and community services, starting with Singapore. There are two types of government expenditures in Singapore: (1) operating expenditure, a larger expenditure that refers to expenditure on manpower, etc.; and (2) developing expenditure, a smaller expenditure that excludes loans to statutory boards, and industrial and commercial enterprises. The largest portion of the operating expenditure is spent on education $^{9}$ and health, while most of the development expenditure goes to education and housing. In Singapore, only the destitute, disabled or chronically ill, and those with no independent means of financial support, are entitled to welfare assistance (Lim and Tay 1991). The Central Provi- 
Table 5.2 Government expenditures on social and community services in Singapore and Thailand

\begin{tabular}{|c|c|c|c|c|c|c|}
\hline $\begin{array}{l}\text { Year/ } \\
\text { period }\end{array}$ & Total & $\begin{array}{l}\text { General } \\
\text { public } \\
\text { services }^{a}\end{array}$ & Education & Health & $\begin{array}{l}\text { Social } \\
\text { security } \\
\text { and welfare }\end{array}$ & $\begin{array}{l}\text { Housing } \\
\text { and } \\
\text { community }^{\text {amenities }}{ }^{b}\end{array}$ \\
\hline 1995 & 38.28 & 8.38 & 16.91 & 5.57 & 3.05 & 4.37 \\
\hline 1996 & 47.21 & 10.53 & 20.12 & 6.66 & 3.84 & 6.06 \\
\hline 1997 & 52.92 & 10.85 & 22.78 & 8.01 & 3.93 & 7.35 \\
\hline 1998 & 54.14 & 10.57 & 25.42 & 7.70 & 4.75 & 5.70 \\
\hline 1999 & 53.11 & 10.65 & 24.96 & 7.18 & 4.89 & 5.43 \\
\hline 2000 & 54.89 & 11.15 & 25.19 & 7.39 & 6.01 & 5.15 \\
\hline \multicolumn{7}{|c|}{ Singapore: Government's share of operating expenditure in social and community services (\%) } \\
\hline & Total & Education & Health & $\begin{array}{l}\text { Environ- } \\
\text { ment }\end{array}$ & $\begin{array}{l}\text { Public } \\
\text { housing }\end{array}$ & Others \\
\hline 1995 & 37.85 & 24.60 & 6.29 & 2.52 & 1.51 & 2.93 \\
\hline 1996 & 35.81 & 23.25 & 5.73 & 2.36 & 1.22 & 3.25 \\
\hline 1997 & 34.75 & 22.12 & 6.46 & 2.00 & 1.28 & 2.89 \\
\hline 1998 & 36.84 & 23.33 & 6.55 & 2.24 & 1.17 & 3.56 \\
\hline 1999 & 34.94 & 21.34 & 6.29 & 2.31 & 1.22 & 3.79 \\
\hline 2000 & 32.00 & 20.65 & 5.24 & 1.89 & 0.98 & 3.24 \\
\hline
\end{tabular}

Singapore: Government's share of development expenditure in social and community services (\%)

\begin{tabular}{llrllll}
\hline & Total & Education & Health & $\begin{array}{l}\text { Environ- } \\
\text { ment }\end{array}$ & $\begin{array}{l}\text { Public } \\
\text { housing }\end{array}$ & Others \\
\hline 1995 & 43.77 & 16.69 & 7.00 & 6.05 & 10.66 & 3.37 \\
1996 & 45.30 & 9.34 & 5.14 & 7.52 & 14.76 & 8.54 \\
1997 & 26.37 & 8.49 & 2.49 & 6.06 & 6.70 & 2.62 \\
1998 & 40.45 & 13.04 & 2.19 & 8.59 & 13.97 & 2.65 \\
1999 & 47.08 & 13.63 & 1.02 & 9.48 & 20.64 & 2.32 \\
2000 & 42.16 & 16.92 & 1.36 & 6.36 & 15.02 & 2.51 \\
\hline
\end{tabular}

Sources: For Thailand, computed from ADB, Key Indicators of Developing Asian E Pacific Countries; for Singapore, computed from Yearbook of Statistics, Government of Singapore.

Notes

a Includes Public Order and Safety.

b Includes recreation, culture and religious activities.

dent Fund (CPF) is regarded as an effective means to look after the poor and the retired (see Table 5.2).

Thailand's public budget was large ${ }^{10}$ and for many years the government paid a great deal of attention to the social sector, increasing the Ministry 


\section{Income distribution in Singapore and Thailand}

of Public Health (MoPH) budget by over 10 percent annually. In the 1990s, the MoPH budget increased more than fourfold, in real terms. The proportion of the health budget in the overall government budget increased from 4.2 percent in 1989 to 7.7 percent in 1998. However, a large portion of the budget was earmarked for investment activities, e.g. new buildings and sophisticated medical equipment. The MoPH capital expense category went up to 38.7 percent in 1997, the highest in the last 35 years. ${ }^{11}$

\section{Effects of the crisis on income distribution and poverty}

\section{Singapore}

The Department of Statistics, DOS (2000), noted that while the Gini coefficient of household income for Singapore in 1990 was 0.436 , it increased to 0.444 in 1997 , rising slightly in 1998 , and increasing to 0.467 as an effect of crisis in 1999. ${ }^{12}$ The Gini coefficient provides the normalized aggregate of relative deprivation, which is measured by the difference in incomes of the people in the state. This deprivation or the Gini coefficient might increase due to several reasons. Two factors were noticed for the increase in inequality in Singapore during 1999. Firstly, the number of lower-income households increased; households with monthly incomes below $\$ \$ 3,000$ increased to 42 percent in 1999, from 40 percent in 1998 (DOS 2000). ${ }^{13}$ Secondly, there was a decline in the income of all households, except the top 10 percent, and the lower income classes were worst hit.

Table 5.3 shows that during 1998-1999 the average household income of the bottom decile decreased by 48.4 percent, while this decrease for total households was only 2.7 percent. Figure 5.1 shows the trend in unemployment rate: note that the unemployment rate started rising from June 1998. ${ }^{14}$ During this time the unemployment rate was 3.2 percent reaching a peak at December 1998 to 4.6 percent, dropping to 3.8 percent in March 1999, and up again in June 1999 to 4.6 percent.

Figure 5.2 shows that in general the unemployment rate is very high among the bottom 10 percent of the residents and the unemployment rate for this group increased from 28.2 percent in 1998 to 44 percent in 1999, an increase of about 56 percent, while for the total labor force the increase was 42 percent. Along with job losses, all the top five occupations at the bottom decile experienced a pay cut of 13 to 34 percent (DOS 2000).

Thus the increase in inequality in Singapore during the crisis is an effect of unemployment, which is more prominent at the lower deciles, generally composed of less skilled and educated workers; there are wage cuts at the lower deciles and wage increases in the upper deciles. It is quite perplexing to note that during the crisis, most of the top occupations in 
Table 5.3 Average household income from work in Singapore, by decile

\begin{tabular}{lrrrrr}
\hline & 1990 & \multirow{2}{*}{1998} & 1999 & \multicolumn{2}{c}{ Annual change(\%) } \\
\cline { 5 - 6 } & & & & 1998 & \multicolumn{1}{c}{1999} \\
\hline Total & 3,076 & 4,822 & 4,691 & 1.6 & -2.7 \\
Bottom 10\% & 370 & 258 & 133 & -21.1 & -48.4 \\
Next $10 \%$ & 934 & 1,332 & 1,172 & -1.5 & -12.0 \\
Next $10 \%$ & 1,321 & 2,005 & 1,853 & 0.1 & -7.6 \\
Next $10 \%$ & 1,686 & 2,647 & 2,470 & 1.3 & -6.7 \\
Next $10 \%$ & 2,075 & 3,305 & 3,137 & 1.6 & -5.1 \\
Next $10 \%$ & 2,541 & 4,097 & 3,900 & 1.9 & -4.8 \\
Next $10 \%$ & 3,116 & 5,034 & 4,828 & 1.9 & -4.1 \\
Next $10 \%$ & 3,897 & 6,271 & 6,023 & 2.9 & -4.0 \\
Next $10 \%$ & 5,151 & 8,221 & 7,937 & 3.2 & -3.5 \\
Top $10 \%$ & 9,669 & 15,053 & 15,451 & 1.1 & 2.6 \\
\hline
\end{tabular}

Source: DOS (2000).

the top decile experienced salary increases (DOS 2000). This is mainly due to the fact that the Singaporean economy depends on foreign expatriate labor. When the Singapore dollar depreciated against the US dollar during the crisis, more attractive salary packages were offered to the expatriates, to prevent foreign expertise from leaving Singapore.

The skilled labor shortage is the reason for the high inequality in Singapore and during the crisis the labor-short economy acted in a way to secure the skilled labor, which had an adverse impact on inequality. ${ }^{15}$ No

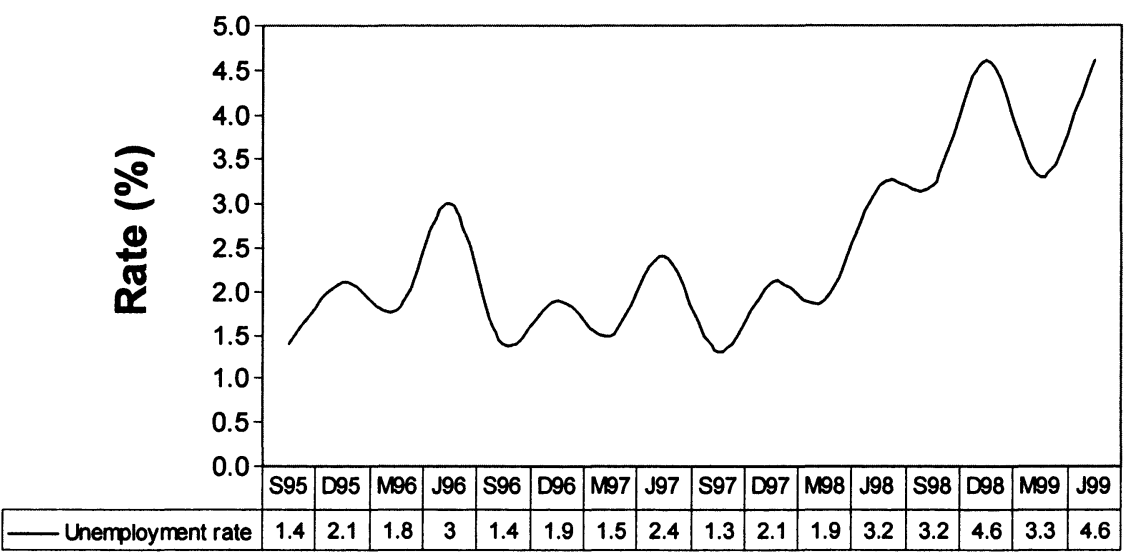

Figure 5.1 Unemployment rate (unadjusted) in Singapore, 1995-1999. Source: Reports on the Labor Force Survey of Singapore, (Ministry of Manpower 1999), Government of Singapore. Note: $S=$ September; $D=$ December; $\mathrm{M}=\mathrm{March}$; = July for various years.) 


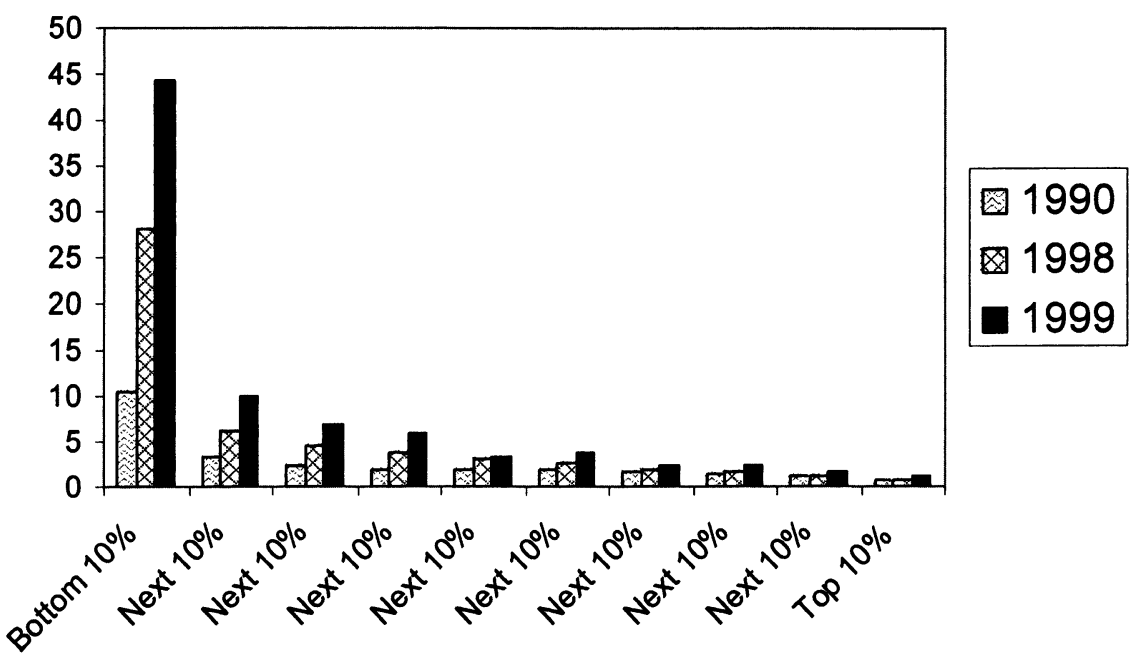

Figure 5.2 Unemployment rate in Singapore, per person aged 15 years and older in resident private household, per decile, in percent (source: DOS 2000.)

data set is available for Singapore to assess the impact of crisis on the most vulnerable members of society, namely the elderly and women with little education.

\section{Thailand}

In 1993 the Thai government liberalized Thailand's financial markets. From that point on, huge amounts of foreign currencies were brought in for non-productive investment, particularly in the oil refinery, automobile, real estate and private hospital industries. The overvalued Thai currency, the baht, reduced its competitiveness and slowed down exports, resulting in the large current account deficit. Attacks on the baht in early and mid1997 resulted in great losses in foreign reserves and the introduction of the "managed float" policy of the Central Bank of Thailand on 2 July 1997 caused rapid devaluation. The major outcome was the bankruptcies of industries and businesses. In the construction industry, 0.9 million fewer people were employed in February 1998 compared to one year earlier. In addition, 25,000 people lost their jobs due to the collapse of the financial companies and more were retrenched from real estate and other financerelated businesses. ${ }^{16}$ The Labor Ministry reported that in total 330,000 people had been laid off from industrial jobs between January and July 1998. The main impact on employment, however, came from the smaller farms (Kakwani 1998). "By a conservative estimate, the total number of 
lay-offs in Urban Thailand between the float and the end of 1998 was 2 million and may have been higher" (Phongpaichit and Baker 2000: 86).

As a strategy for survival, many laid-off workers accepted whatever employment they could find even at a considerable reduction in wages; some of the retrenched people chose to live on their savings, and some started their own business (Sauwalak and Chettha 1999, referred to in Phongpaichit and Baker 2000). These own businesses created a big informal sector; however, due to lack of demand for the goods of this informal sector, these businesses did not last for long. Moreover, vending and petty services were cleaned up by official measures prior to the hosting of the Asian Games in 1998.

Instead of retrenching, some of the farms in Thailand reduced the number of working hours and lowered the wages. The World Bank Thailand (2000) found that in February 1998, the number of people working less than 20 hours had almost doubled compared to the figure of one year earlier. In Bangkok alone, the number of underemployed rose tenfold, and this was seen in all the urban areas.

Along with job losses, the average real earnings of the Thai people decreased during the crisis period. ${ }^{17}$ Real wages in all the sectors - commerce, manufacturing, service and constructions - dropped during the 1997-1999 period. The drop is most severe in commerce; manufacturing and services recovered slightly at the end of 1998. The decrease in business earnings was more severe than the wage cuts (Figure 5.3), while business earnings dropped by 15.5 percent in 1997-1998, the wage decrease was by 3.1 percent. In the year following the corresponding figures were

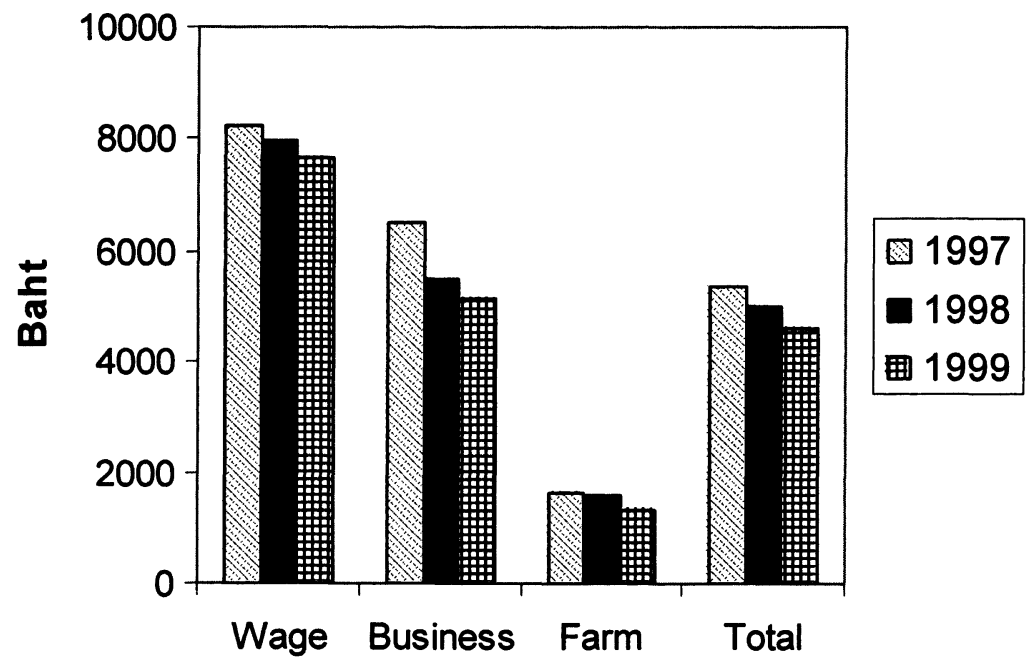

Figure 5.3 Real incomes by origin in Thailand, 1997-1999 (source: NESDB, Indicators, 3(3), 1999.) 
6.4 percent and 3.8 percent respectively. The huge drop in income in the farm sector during 1998-1999 can be attributed to the reverse migration of the retrenched urban workers to villages. The problem has been exacerbated by a severe, long drought: as of December 1997, a total of 12,831 villages, involving 7.7 million people, had been affected by the drought (WHO 1998). This shows that the effects of the crisis which initially were mainly concentrated to the urban areas, later spread to the rural parts of the country.

Besides changes in the demand and supply in the labor market, real earnings decreased due to the high inflation rate caused by the crisis. ${ }^{18}$

\section{Changes in income inequality}

The situation in the labor market explains the increase in income disparity in Thailand during and after the crisis. From Table 5.4 it is observed that the Gini coefficient increased during 1998-1999 and this happened mainly due to the increase in income share at the top quintile. ${ }^{19}$ We have mentioned previously that the Thai income inequality is best explained by the educational disparity. To explain further the increase in inequality during 1998-1999, we present Figure 5.4. This shows that lower qualifications attract not only lower salaries, they are the most hard hit by the crisis. People in the labor force with no education experienced a 16 percent drop in wages during 1998-1999, while there was an increase in wages for the people who have an upper secondary education or higher.

Table 5.4 Current income share of households in Thailand, by quintile, and the Gini coefficient

\begin{tabular}{lcccc}
\hline Quintile group & \multicolumn{1}{c}{1994} & \multicolumn{1}{c}{1996} & \multicolumn{1}{c}{1998} & $1999^{a}$ \\
\hline 1 & 5.6 & 5.7 & 5.9 & 5.3 \\
2 & 9.1 & 9.2 & 9.6 & 8.9 \\
3 & 13.6 & 13.5 & 13.7 & 13.3 \\
4 & 21.3 & 21.5 & 21.0 & 20.9 \\
5 & 50.4 & 50.1 & 49.8 & 51.6 \\
Total & 100.0 & 100.0 & 100.0 & 100.0 \\
Gini coefficient & 0.431 & 0.429 & 0.421 & 0.444 \\
$\begin{array}{l}\text { Per capita current } \\
\text { income (baht per } \\
\text { month) }\end{array}$ & 2,166 & 2,890 & 3,283 & 3,389 \\
\hline
\end{tabular}

Source: The 1994, 1996, 1998, 1999, and 2000 Household Socio-economic Survey, National Statistical Office (NSO).

Note

a The data collection period was from June-September 1999. 


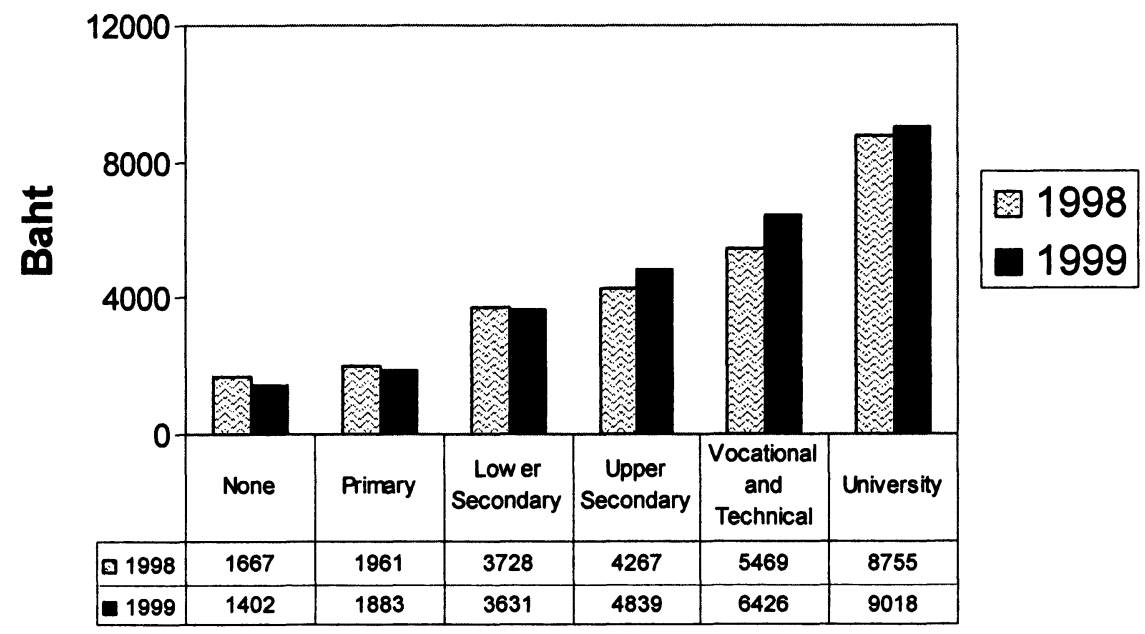

Figure 5.4 Incomes at various education levels in Thailand (source: World Bank 2001.)

The maximum increase in salary was found for the people with vocational and technical backgrounds, who experienced a 17.5 percent increase in salary.

It is important to note that the issue of foreign workers and inequality is not as important for Thailand as it is for Singapore. Singapore recruits more skilled labor from foreign countries compared to Thailand, and this policy did not change during and after the crisis; thus for Singapore, the migration of foreign labor is the main reason for the increase in inequality.

\section{Changes in poverty}

During the crisis period the incidence of poverty increased dramatically in the Northeast region of Thailand. The Southern and Central regions also experienced some increase, while poverty actually decreased in Bangkok (World Bank 2001). The regional disparity of the incidence of poverty, as we noted before, has become quite pronounced as a result of the crisis. Most people in the Northeast region are farm operators (32.4 percent) and more than 15 percent of the population in the region depend upon transfer earnings. The poverty rate among farm operators (including tenants) increased very rapidly during the crisis. Figure 5.3 indicates the decrease in rural income at the farm level. Although the economic crisis originated in the financial sector of Bangkok, the Northeast was the region that was the worst affected by the crisis. Some other factors added fuel to this increase in poverty: 


\section{Income distribution in Singapore and Thailand}

1 As an effect of the financial shock, firms reduced wages paid to employees. Earnings for the self-employed also decreased. Thus remittances back to the rural sector decreased.

2 Because of the crisis, the exodus to the cities, particularly to Bangkok, stopped and this has adversely affected the household incomes in the rural areas of Northeast, South and Central.

Thailand showed increases in both income inequality and poverty during the crisis. The crisis created huge job losses and the real wages decreased due to the adverse labor market conditions and the hike in the inflation rate. Better-educated people, generally at the higher end of the income ladder, were not that badly affected. The incidence of poverty most seriously affects the less developed regions. One question yet remains to be addressed: whether the increase in poverty is due to a decrease in the growth rate, or due to the adverse distribution of income. Kakwani (2001) developed a methodology to estimate the effects of inequality and that of growth on the change in poverty. Using 1998 household survey data, he found that Thailand has a 4.1 inequality-growth trade-off index. This means the income inequality has a 4.1 times greater influence on poverty compared to the rate of growth. ${ }^{20}$

A World Bank (2001) calculation suggests that had the distribution of income remained neutral between 1998 and 1999, the incidence of poverty would have fallen by a modest 0.5 percent points. However, this period witnessed a 3 percent point increase in poverty. Furthermore, in absolute terms, the worsening inequality resulted in an additional 2.1 million persons falling below the poverty line between 1998 and 1999 .

\section{Effects on the education sector}

We have seen that due to the financial crisis the unemployment rate increased, prices rose, private incomes decreased, and because of the consequent decrease in national income, government budgets were sliced. A net change in the demand for education is also expected due to the following reasons:

1 With the decline in the household income, the income elasticity of demand for education is expected to decline. However, if households expect that the crisis is short-lived, they might use their past savings for higher education. The expectations regarding the duration of the crisis are a determinant of the usage of savings on education.

2 The opportunity cost of seeking education declines with the widespread unemployment of educated people. If the direct cost of education is reduced, the demand for post-secondary education might increase. 
3 If the government intervenes by providing short-term scholarships and bursaries, demand might increase.

4 The expected future earnings of the individuals also have their effect on the demand for education, particularly for higher education.

5 A large number of students from Southeast Asia go to the US, UK and Australia for their higher education. A reduction in the household incomes, caused by job losses and the decline in the exchange rate, affects the demand for this overseas higher education. The demand for higher education in the home country is just a substitute for that.

\section{Singapore}

Singapore typifies the expansion of the education system from basic through higher education, including technical and vocational schools since 1959. The Singaporean government has taken full responsibility for the education policy, financing and system development of the entire education system. The recent economic crisis in East Asia might have prompted shifts in education and other social sectors. We will investigate that first and then try to explore any changes in enrollment, etc. that can be attributed to the financial crisis.

\section{Government budget}

Table 5.5 presents Singapore's expenditure on education in real terms. The government total expenditure on education increased over time: during the crisis period the increase rates are 18 percent, 9 percent and 18 percent in the years 1996-1997, 1997-1998 and 1998-1999 respectively. However, a 5 percent decrease in the recurrent expenditure is noticed in 1997-1998. It is worth noting that during that period the development expenditure increased by 53 percent.

Table 5.5 Singapore government's real expenditure on education, 1995-1999

\begin{tabular}{lrrrrr}
\hline & 1995 & 1996 & 1997 & 1998 & 1999 \\
\hline Total & 35,613 & 39,007 & 46,016 & 50,187 & 59,135 \\
Recurrent expenditure & 27,740 & 30,994 & 34,620 & 32,755 & 35,289 \\
Primary schools & 6,719 & 7,901 & 8,582 & 8,466 & 8,600 \\
Secondary schools and & 8,598 & 9,765 & 10,540 & 10,063 & 10,906 \\
$\quad$ junior colleges & & & & & \\
ITE & 1,134 & 1,168 & 1,286 & 1,246 & 1,146 \\
Tertiary & 9,309 & 10,335 & 11,727 & 10,455 & 11,482 \\
Polytechnics & 3,505 & 4,071 & 4,439 & 4,340 & 4,198 \\
Development & 7,874 & 8,012 & 11,396 & 17,432 & 23,846 \\
$\quad$ expenditure & & & & & \\
\hline
\end{tabular}

Source: The Budget, Republic of Singapore, various issues, and author's calculations. 


\section{Income distribution in Singapore and Thailand}

In the 1990s the average government recurrent expenditure per student, in real terms, at the primary level was $\$ \$ 2,424$, while those at secondary, polytechnic and university levels were, respectively, $\$ \$ 3,755$, $\$ \$ 6,906$ and $\$ \$ 14,681$. This expenditure per student increased at a rate of 3.8 percent at primary level, 8.3 percent at secondary level, 2.1 percent at polytechnic level and 11.2 percent at university level during 1990-1999 (Mukhopadhaya and Shantakumar 2000).

Figure 5.5 shows that when the country was hardest hit by the crisis, that is in 1998, the real recurrent expenditure per student decreased at all levels. However, it must be noted that during 1995-1996, prior to the crisis, the real recurrent expenditure per student at university level

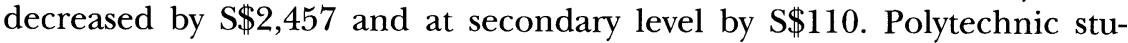
dents experienced a continuous decrease in recurrent expenditure in 1996-1999. Thus it cannot be said with certainty that the decrease in

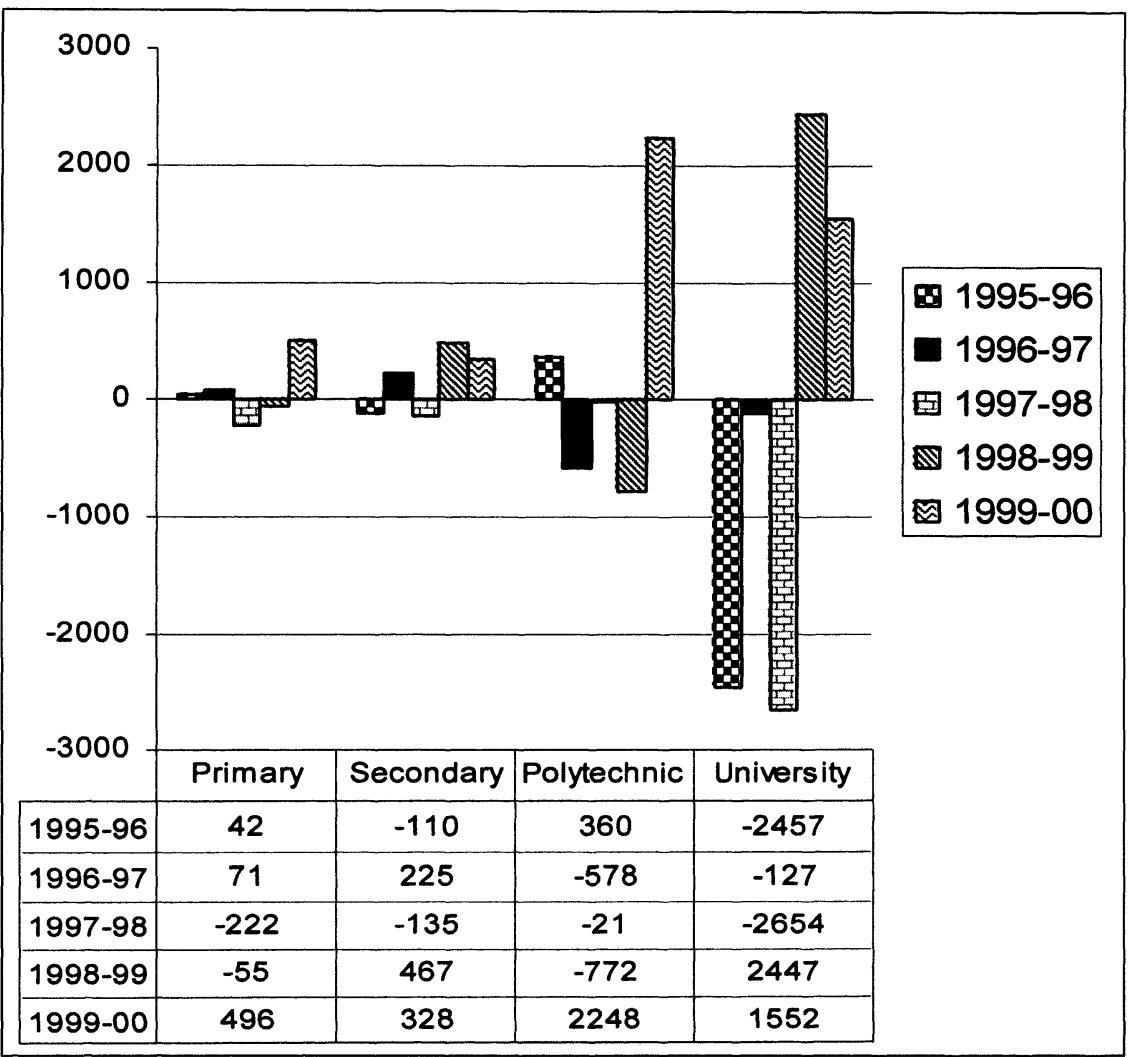

Figure 5.5 Changes in government real recurrent expenditure per student in Singapore, 1995-1999 (S\$) (source: Yearbook of Statistics, Government of Singapore, various years.) 
government recurrent expenditure on education during 1997-1998 was an effect of the crisis.

\section{Enrollment}

With the structural change from the mid-1980s the Singaporean economy needed skilled manpower and Singaporeans realized the existence of skillpremiums in terms of salaries. The government's initiative to expand education created an upward trend in enrollment rates at all levels of education. $^{21}$ The total change in enrollment (Figure 5.6) during 1997-1998 is slightly lower than the years preceding and following it, due to a decrease in enrollment at the secondary level. At the secondary level, enrollment decreased by 4.3 percent and 3.3 percent during 1997-1998 and 1998-1999 respectively. The university enrollment has increased, without any doubt, from 1996 and onwards. The increase in university enrollment is due to the expansionary government policies which started in early 1999. Also many students from the region, who were unable to go to the US, the UK or Australia due to the adverse exchange rate situation, entered universities in Singapore instead. There is no evidence in Singapore, however, that students already enrolled at overseas universities had to transfer to Singaporean universities owing to the financial crisis.

The increase in enrollment at the Institute of Technical Education $(\mathrm{ITE})^{22}$ was spectacular. Singaporeans on the whole expected that the

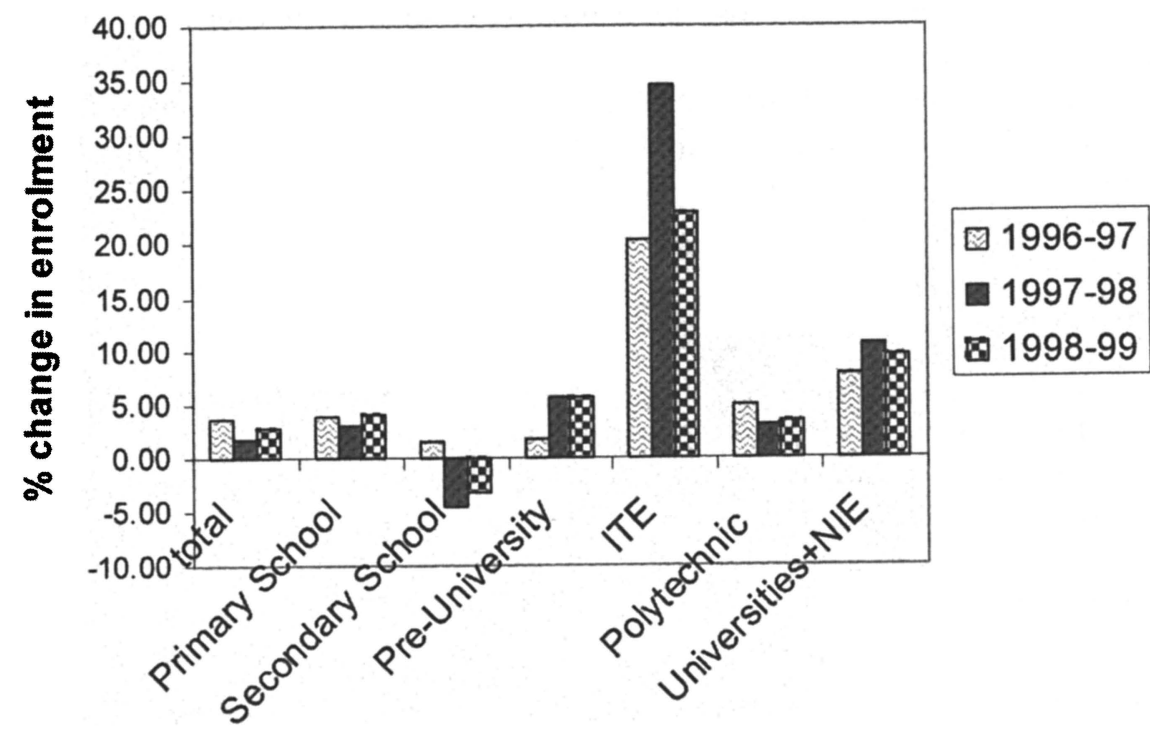

Figure 5.6 Changes in enrollment at various educational levels in Singapore, 1996-1999 (source: World Bank 2001.) 
crisis would be short-lived and utilized the crisis period, when the opportunity cost of skill development was low, to gather some extra skills from the technical institutes. The government also took some initiatives at the beginning of the massive retrenchment phase to retrain the adult workforce. The $\mathbf{S} \$ 15$ million Skill Development Center started in early 1999 with the aim to provide as many opportunities as possible for Singaporeans to retrain and upgrade their skills. ${ }^{23}$ The funding came from the $\mathrm{S} \$ 20$ million grant provided by the government to expand training places under the skill redevelopment program.

The decrease in secondary school enrollment starting in 1998 is not an effect of the crisis, but due to the decrease in the birth rate, caused by the expansion of education and the increasing numbers of women joining the workforce. ${ }^{24}$

\section{Household budget}

The loss of employment in the household has both income and substitution effects on the demand for the consumption basket. The immediate income effect reduces the quantity demanded for the same consumption basket and households might reallocate the consumption basket and go for the item of primary importance, so-called substitution. If higher education is an item of priority consumption or investment, the household is expected to readjust its budget to protect the expenditure on education. Empirical evidence shows that the reaction of households depends upon the country-specific situation. ${ }^{25}$ Also there could be variations within the same country. ${ }^{26}$

Education is a highly subsidized sector in Singapore. Also, the Singaporeans expected the crisis to be an extremely short-lived phenomenon. The average household income of Singapore is also quite high compared to other Southeast Asian countries. The Department of Statistics (DOS $1997 / 1998$ ) indicates that the loss of income as a result of the crisis hardly had any effect on the education expenditures of the Singaporeans. ${ }^{27}$

\section{Thailand}

There have been substantial gains made in the Thai education system. Enrollment at most general education levels and in vocational and technical training schools has grown rapidly. Education has been made compulsory through grade nine. The literacy rate for all age groups is estimated at 90 percent. ${ }^{28}$ Let us now examine the effect of the crisis on the Thai education system.

\section{Government expenditure}

The Thai government kept public expenditure on education at a constant level during the crisis. The nominal planned education spending in fiscal 
Table 5.6 Education expenditure of Thailand, 1995-1999 (million baht)

\begin{tabular}{llllll}
\hline & 1995 & 1996 & 1997 & 1998 & 1999 \\
\hline Education budget & 135,308 & 164,560 & 202,864 & 206,944 & 207,316 \\
Nominal actual spending & 129,496 & 157,866 & 201,625 & 218,211 & \\
Real actual spending & 122,420 & 141,015 & 170,536 & 170,771 & \\
\hline
\end{tabular}

Source: World Bank (1999).

year 1998 stood at 207 billion baht, comprising 24.9 percent of the total budget, up from the 21.9 percent share in the previous year. The 1999 fiscal year budget allocated 207.3 billion baht (Table 5.6).

At the micro level the government expanded the scholarships ${ }^{29}$ and loan programs ${ }^{30}$ with special emphasis on the needs of unemployed parents. Anticipating increased unemployment after the crisis, parents are allowed to pay tuition fees in installments and schools are permitted to waive tuition fees on a case-by-case basis. Also private schools are encouraged to extend payment deadlines and are prohibited from increasing tuition fees. The government also provided vouchers to private school children in the Bangkok metropolitan area to allow them to continue at those schools, and encouraged local and international schools to accommodate students returning from overseas.

\section{Enrollment}

The demand for education, thus, increased because of the various government programs, in spite of the decrease in real incomes. The National Statistical Office (various issues) concludes that the crisis had a very limited negative impact on overall enrollment. There was a marginal decrease in the number of students at the pre-elementary and the lower secondary levels, but an increase in the elementary and upper secondary education levels. A comprehensive study by the Asian Development Bank (ADB) ${ }^{31}$ notes, however, a high drop in enrollment ratios from Grade 1 to Grade 2 - 9.4 percent from 1996-1997 to 1997-1998, and 8.2 percent from $1997-1998$ to $1998-1999$. The decrease in the vocational school enrollment in the years after the start of the crisis, 1998-2000, is quite dramatic, by 50,000 students. This is a stark contrast to the Singaporean situation.

\section{Dropouts}

With rising unemployment and rising prices reducing the household income, it is natural to expect an increase in dropout rates. To analyze the case of Thailand, two studies are available: the World Bank study using SES $(1996,1998)$ and the ADB sample survey on 220 schools. The ADB 
survey reports the highest rise in school leavers in the school year (SY) 1997-1998: 23.6 percent for lower secondary and 35.9 percent for upper secondary. During SY 1998-1999, there was a decrease in the dropout rate: 20.5 percent in lower secondary and 33.1 percent in the upper secondary. The World Bank finds that the ratio of children not attending lower secondary school declined from 7 percent in SY 1996-1997 to 6.7 percent in 1998-1999. SES (1998) observes that the largest decline in dropouts occurred in the pre-school age group (3-5 years); at the primary level the dropout rate declined by 2 percent. For the upper secondary the dropout rate was 32.7 percent in 1996, and declined to 29 percent in 1998. The dropout rates between 1996 and 1998 declined in both rural and urban areas, implying that the adverse effects of the crisis on education were not pronounced. Dropout rates decreased at all education levels in all regions of the country with one exception: in the Central region the dropout rates increased slightly at the lower secondary level; in particular there is a significant increase in dropouts in Bangkok and nearby areas. This is perhaps because parents who lost their jobs moved with their children from the metropolitan Bangkok area to other regions.

A further analysis of the SES data by the World Bank reveals that although there was an overall improvement in school attendance, the poor households remained disadvantaged. At the primary age group the dropout rate among the poor is almost twice that among the non-poor. At a higher age the divergence is much greater.

The Office of the National Education Commission also collects data on dropouts. They define the dropout rate as the number of students who do not advance from one grade to the next grade each year, as well as those

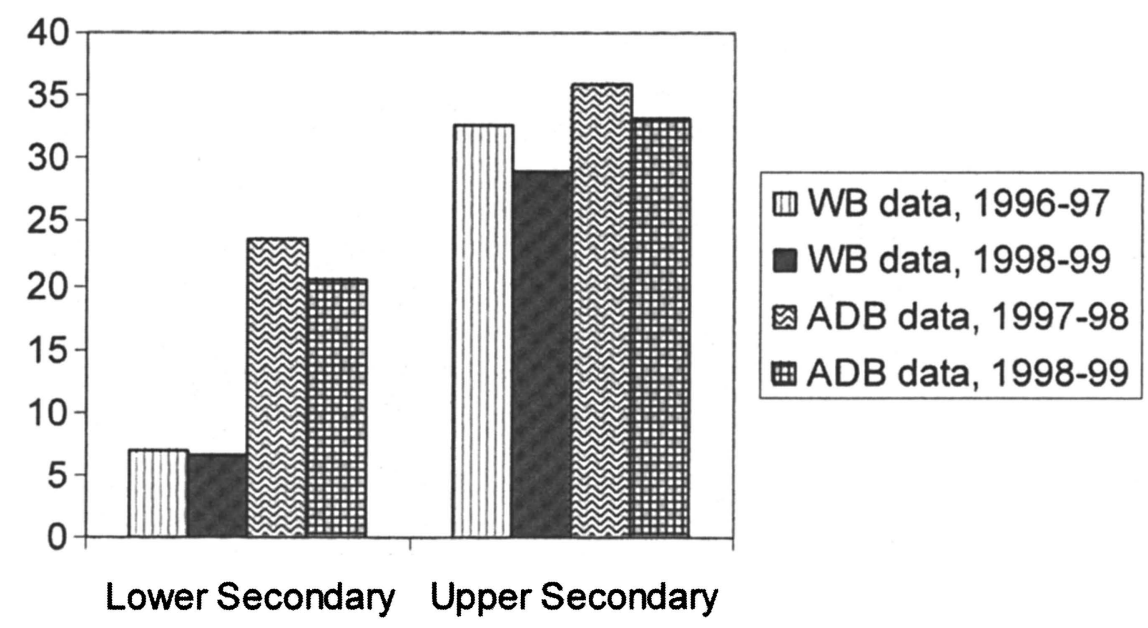

Figure 5.7 Changes in drop-out ratios in secondary schools in Thailand (source: Asian Development Bank, World Bank.) 
who are enrolled in the final year but do not graduate. With this definition it was found that, as a percentage of the school age population, dropouts increased from 5.5 percent in SY 1997-1998 to 6.7 percent in 1998-1999.

From the observations above, we cannot draw conclusions on the changes in the dropout rate during the crisis. One would have expected that with the loss of employment and the decrease in income, poor parents would withdraw their children from school in order to supplement the family income. The Labor Force Survey of Thailand (1998, 1999) reveals, however, that there was no increase in child labor (children aged 13-17, not attending school as they are in the workforce or working at home) during the crisis. Moreover, the unemployment rate of children aged 13-17 increased substantially during the crisis period, which worked as a disincentive to the parents to withdraw their children from schools.

\section{Household budget}

When faced with rising inflation, declining incomes and loss of employment, irrespective of level of income, people made similar changes to their expenditure patterns. The largest increase in real spending was found in education, while households significantly decreased their expenditures on alcohol and tobacco, food and beverages, apparel and footwear, transportation and communications, and recreation (National Statistical Office).

At the level below tertiary school, the expenditure per child attending school increased from 262 baht per month in 1996, to 297 baht per month in 1998. However, the average monthly expenditure per child attending public school decreased from 67 baht to 59 baht during the same period (World Bank 1999), as a result of the government's policy to waive tuition fees for the needy. This resulted in increased enrollment rates at public schools.

Thus, two effects of the decrease in household income have been identified. Firstly, households changed their consumption basket by spending more on highly preferred goods, such as education, and cutting the budget on non-essential consumption, and to some extent reducing food and medical costs. ${ }^{32}$ Secondly, cheaper quality goods were substituted for more expensive ones, such as transferring children from private to lowcost public schools. ${ }^{33}$

\section{Health sector}

We have seen that over the last 25 years both Singapore and Thailand have achieved spectacular progress in terms of health. It was feared that the effectiveness, affordability and equity of the health care supply would be affected by the increase in the cost of drugs and other imported items, 


\section{Income distribution in Singapore and Thailand}

and the decrease in funding of the public health care services. However, the governments of both Singapore and Thailand were quite conscious of the health care provided to their peoples.

\section{Thailand}

In Thailand the cut in public health expenditure was limited when compared with the previous years. Health expenditures were 8 percent lower in 1998 than 1997, and 14 percent lower in $1999 .{ }^{34}$ The adjustment in 1998 was effected in the following way: in nominal terms, the budget for capital investment decreased by 38.5 percent between 1996 and 1998, while the budget for salaries and for operating expenses both increased by 9 percent and 8.3 percent respectively (Mokoro 1999). Because of the unavailability of data it is not possible to judge the effect on the poorest people, those in the bottom decile in the country. However, from Table 5.7 it can be seen that the household budget portion for medical expenditure decreased during 1997-1998.

In Thailand, 80 percent of the population is covered by the health insurance scheme (Wibulpolprasert 1999), which means that 20 percent of the population, mostly self-employed people of low and middle income, is uninsured. During the crisis this percentage increased. The crisis witnessed the expansion of the publicly subsidized voluntary health card scheme and the social welfare health insurance scheme. The coverage of the social welfare scheme increased from 43.9 percent in 1996 to 45.1 percent in 1998 and the health card scheme increased from 7.8 percent in 1995 to 13.9 percent in 1998 (Wibulpolprasert and Pengpaiboon 2001). Despite the decrease in overall $\mathrm{MoPH}$ budget during the crisis, the budget for social welfare health insurance increased 25.6 percent in real terms from 1997 to 1999 (Wibulpolprasert 1999). In 1995, a program to increase the number of doctors in rural areas was launched; after the crisis, the number of students in this program increased. In 1998 the MoPH had a net loss of doctors of only 3.6 percent of the new recruits as compared to

Table 5.7 Government budgets for the health sectors in Thailand and Singapore, 1995-1999

\begin{tabular}{lll}
\hline & Thailand (million baht) & Singapore (S\$ million) \\
\hline 1995 & $52,372.7$ & 13.56 \\
1996 & $63,452.2$ & 11.44 \\
1997 & $72,406.0$ & 12.14 \\
1998 & $66,455.2$ & 12.33 \\
1999 & $62,546.3$ & 11.40 \\
\hline
\end{tabular}

Source: Wibulpolprasert (2002) and computed from The Budget, Republic of Singapore, various issues. 
30.2 percent in 1997 (Wongwatcharapaiboon et al 1999) and the doctorto-bed ratio decreased from $1: 15.3$ in 1998 to $1: 14.6$ in 1999 (Phokpermdee et al. 1999). To reform drug management, a collective provincial procurement system for all districts and provincial hospitals was implemented nationwide (Na Songkhla et al. 1999). In 1999, a 27.7 percent savings was achieved with 336 million baht saved by the collective drug purchases. This cost reduction occurred in spite of the fact that drug prices increased from 1997 to 1999 by 22.85 percent for imported drugs and 20.63 percent for locally produced products (Wibulpolprasert 1999).

Most of the private hospitals in Bangkok had substantial foreign currency loans and confronted serious repayment problems in the wake of the steep devaluation of the baht. The newly opened private hospitals suffered the most. The WHO (1998) reported that about 33 percent of the private facilities were expected to close over the next 2-3 years.

\section{Singapore}

In Singapore, health care, pensions and housing are managed through the Central Provident Fund (CPF) scheme. CPF contribution rates were 40 percent (20 percent for the employer and 20 percent for the employee) in July 1992, with a maximum monthly contribution of $\mathbf{S} \$ 2,400$. The rate was reduced to 30 percent in January 1999 to cope with the 1997 economic crisis, with a monthly maximum contribution of $S \$ 1,800$. People in the labor force above 55 years of age are subject to a lower rate of contribution since July 1988. This is designed to partly unlink wages from seniority, and to reduce the cost of hiring older workers (CPF Board Annual Reports, various years). The CPF contributions are channelled into three separate accounts, Ordinary Account, Special Account and Medisave Account.

Ordinary Account For those younger than 55 years, between 72.2 and 61.1 percent of the contribution is channelled into the Ordinary Account depending on age, with the proportion decreasing with age. Balances in this account can be used for housing, pre-retirement investments and other purposes.

Special Account For those younger than 55 years, between 11.1 and 16.7 percent of the contribution is channelled into the Special Account, with the proportion increasing with age. However, those aged over 55 years do not contribute to this account. Although the balances in this account are for retirement purposes, recent reforms have permitted them to be used for certain "safe" investments. It should be noted that the government has specifically created this account so that people would have sufficient money to look after themselves after retirement. 


\section{Income distribution in Singapore and Thailand}

Medisave Account The Medisave Account can be used to pay for hospital and selected outpatient services; and for the catastrophic health care insurance premium under the Medishield ${ }^{35}$ (and Medishield Plus) ${ }^{36}$ Scheme. Unlike the other two accounts, the self-employed must contribute to this account. The contributions are channelled into Medisave with the proportion increasing with age. For those younger than 55 years, between 16.7 and 22.2 percent is channelled into this account, but for those above 55 years this proportion varies from 43.2 to 100.0 percent. The amount in this account cannot be fully withdrawn until the death of the account holder, and it is then distributed to the beneficiaries of the member. This enforced saving ensures that Singaporeans will be able to finance their medical care even after retirement.

However, it must be noted that the health insurance schemes Medishield and Medishield Plus have inadequate coverage, with more than a third of the population not covered by either scheme. The schemes have narrow scope, not covering many illnesses, including pre-existing illnesses, and pay only a small proportion of the total hospital bill, typically between 25 and 40 percent. The rapid accumulation of Medishield balances suggests that the premiums are levied on the basis of over-conservative assumptions in relation to the benefits actually paid (Asher and Karunarathne 2001). Thus in 1999, the insurance premiums under Medishield were $\mathbf{S} \$ 95$ million while the payments were only $\mathbf{S} \$ 47$ million. ${ }^{37}$ Nevertheless, Singapore has integrated health care finance with retirement finance.

While the gross contribution to the CPF has been impressive, the existence of a large number of pre-retirement withdrawals, particularly for housing, has meant that the net contribution has been rather low. During 1987-1999, about 70 percent of the contributions were withdrawn during the year. Such a high level of withdrawals for non-retirement purposes, particularly for housing, has adversely affected the accumulation of balances. Thus in Singapore, in spite of high contribution rates and rapid economic growth, the retirement balance is inadequate. ${ }^{38}$

Thus it is observed that the health sector of Thailand experienced budget cuts and due to the loss of demand and currency devaluation, private hospitals closed down. However, some of the government programs were able to bring some equity in the health care system during the crisis. In contrast, the budget cut in the health care provision for Singapore was marginal and the government did not take any specific measure to protect the vulnerable, as the poorest members of the population are mostly protected by a well designed system of wages.

\section{The government's action to protect the vulnerable}

It has been observed that due to the crisis-generated job losses and the decrease in real wages, income distribution worsened for both Singapore 
and Thailand, and the number of people below the poverty line increased. Even in Singapore, the crisis mainly affected the most vulnerable members of society: the elderly, the unskilled and less educated workers, and women. Both governments have developed several mechanisms to target social assistance, to select the allocation of the scant resources available. It has been observed in the literature that proper targeting is a very complex issue. In low-income countries, less than 10 percent of the total population is covered by some social protection, while in middle-income countries this percentage tends to be between 40 to 80 percent. ${ }^{39}$ Most of the studies do not address this problem for developed countries with high incomes. In this section we will consider our sample countries to check various social protection measures offered by their governments.

\section{Singapore}

We have seen that due to factors related to the reduced growth rate, the income distribution of Singapore worsened during the crisis. In the National Wage Council (NWC) Guidelines of 1998, companies were asked to cut down on the wage cost using the flexible wage system. The employers' contribution to the CPF was also reduced, from 20 to 10 percent for people below 55 years, from 7.5 to 4 percent for the age group 55 to 60 , from 7.5 to 2 percent for people 60 to 65 years of age, and from 5 to 2 percent for those above 65 . This reduction strikes the older people rather unfairly. However, it should be noted that despite the reduction of the employers' contribution, there was no change in the Medisave contribution for the elderly workers.

During the crisis, the Singaporean government had implemented various measures to help individuals and households to combat the difficult situation. One of those was the personal tax rebate. A one-off tax rebate of 5 percent was granted for all resident tax payers for the year 1998 and 1999. A tax relief (effective from YA 1998) for children who live with their aged parents in the same household was raised from $\$ \$ 3,500$ to $S \$ 4,500$. This is on the premise that the working children will look after their parents.

On 24 November 1998, a $\$ \$ 134$ million package of rebates on Housing Development Board (HDB) rents, service and conservancy charges, utilities and public transport was announced to help the poor people to cope with reductions in CPF accounts and bonuses. ${ }^{40}$

1 Rebates on services and conservancy charges and HDB rents were introduced in 1994 to help lower-income families to offset the impact of the general standard tax (GST). The rebates were due to expire in March 1999, but after looking at the effect of the crisis on the lower deciles, the government extended the rebates for two more years, at a cost of S\$22 million. 


\section{Income distribution in Singapore and Thailand}

2 HDB residents living in 4-room flats and smaller units have been given utility rebates for two years, to offset the increase in water and electricity tariffs. Those living in 3-room flats or smaller received $\mathbf{\$} \$ 100$ rebates, while 4-roomers received $\$ \$ 50$ rebates. Grants for service and conservancy charges were also given for 4-rooms and smaller HDB flats. To note that people living in 3-rooms or smaller HDB flats are people from the lower income group; thus this grant is mostly aimed at the poorer section of the society. ${ }^{41}$

3 The government announced a year-long rebate and discount for public transportation for the year 1999. ${ }^{42}$

4 Hospital bills were trimmed by 5 and 10 percent for class B2 and C patients respectively from January 1999. Class C patients were also allowed to apply for help from Medifund, if they were unable to pay their bills.

5 We have mentioned that a large portion of the CPF is used for home mortgages. After the CPF cuts, 18 percent of the members did not have enough in monthly contributions to their ordinary accounts to pay their housing installments. They were allowed to use funds from the Special Account to meet the shortfall. ${ }^{43}$

It must be noted that these sorts of measures are not direct attempts to protect the most vulnerable people during the economic downturn. A simulation analysis by DOS (2000) showed that the tax relief measures could only marginally reduce the inequality. The government of Singapore believes in a more pragmatic approach to welfare, compared to a welfare state with properly developed social safety net. No specific provision was made for the aged or the less educated, who were the first to be affected by economic setbacks. No particular effort was made for women, who were generally the hardest hit by the crisis in these groups.

\section{Thailand}

The crisis highlighted the importance of providing an effective social safety net. To the world organizations, Thailand became the arena where the new social strategies were implemented. In this section we will discuss the various social programs implemented during the crisis and their effectiveness. The information was gathered from SES (1999); this is a special survey and thus it was not possible to compare the results with previous years, but we could examine the programs in terms of reaching the target population group. ${ }^{44}$

\section{Low-income health card}

The low income health card, which is issued for 3 years, is a means-tested program ${ }^{45}$ which entitles the poor in the 13-59 age group to free health 
care at hospitals and public health centers. The program provides 273 baht per head. During the crisis period this program was extended to the unemployed if they were registered at the Ministry of Labor and Social Welfare. It should be noted, however, that the identification of the poor is quite arbitrary and made by the community head. SES (1999) notes that 10 percent of the population had the low income health card, out of which only 38 percent were from the bottom quintile. This shows that the program could have been better targeted. The data on regional distribution of the low income health card shows that the poorest region, the Northeast, received half of the total distributed card (see Table 5.8).

\section{Voluntary health card}

The voluntary health card covers a wider population as it serves those who are near poverty and those who do not have any health insurance. Under this system the card holders can receive free medical care for an annual contribution of 500 baht. Table 5.8 shows that 50 percent of the poorest quintile is covered by the voluntary health card program. One possible explanation, provided by the World Bank (2001), is that people do not have much reliance on the quality of the free service and thus very few people opted for the low income health card program. From Table 5.8 it can be noted that 48 percent of the people from the top two quintiles received the benefit of the voluntary health card, which is actually meant for the disadvantaged. Thus here again, the targeting is not appropriate.

\section{Social pension program}

The social pension program of the Department of Public Welfare and of the Ministry of Labor and Social Welfare targets people who are 60 years and above, who are alone, economically inactive and residing in a village having a Village Welfare Assistance Center. In 1997, this scheme covered 56,534 villages, increasing to 66,409 villages in 1998 . The program paid 300 baht per month during the crisis period (prior to the crisis it paid 200 baht), which is far lower than the National Economic and Social Development Board (NESDB) poverty line for the elderly, or 700 baht. Table 5.8 shows that only 13 percent of the people from the bottom quintile received this benefit. The World Bank (2001) presents that only 1 percent or fewer people in Thailand are poor, of more than 60 years of age, and living alone. Thus the program, by definition, is not meant to reach the most disadvantaged elderly.

\section{Social security cards}

A social security card is available to those who are working in the formal sector. Table 5.8 shows that this program is disproportionately biased to 
Table 5.8 Incidence of various government programs in Thailand.

\begin{tabular}{|c|c|c|c|c|c|c|c|c|c|}
\hline \multirow{2}{*}{$\begin{array}{l}\text { Real per } \\
\text { capita } \\
\text { consumption } \\
\text { quintile }\end{array}$} & \multicolumn{2}{|c|}{ Health program } & \multicolumn{2}{|c|}{$\begin{array}{l}\text { Social security and } \\
\text { social pensions }\end{array}$} & \multirow{2}{*}{$\begin{array}{l}\text { Public } \\
\text { employment } \\
\text { generation } \\
\text { scheme }\end{array}$} & \multicolumn{2}{|c|}{$\begin{array}{l}\text { School nutrition } \\
\text { program }\end{array}$} & \multicolumn{2}{|c|}{$\begin{array}{l}\text { Education assistance } \\
\text { program }\end{array}$} \\
\hline & $\begin{array}{l}\text { Low income } \\
\text { health card }\end{array}$ & $\begin{array}{l}\text { Voluntary } \\
\text { health card }\end{array}$ & $\begin{array}{l}\text { Social } \\
\text { pension for } \\
\text { elderly }(60+)\end{array}$ & $\begin{array}{l}\text { Social security } \\
\text { card }\end{array}$ & & $\begin{array}{l}\text { School lunch } \\
\text { program }\end{array}$ & $\begin{array}{l}\text { Supplementary } \\
\text { food } \\
\text { program }\end{array}$ & $\begin{array}{l}\text { Government } \\
\text { scholarship } \\
\text { program } \\
\text { (upper and } \\
\text { post secondary) }\end{array}$ & $\begin{array}{l}\text { Student loan } \\
\text { program }\end{array}$ \\
\hline
\end{tabular}

\begin{tabular}{lrrrr}
\hline \multicolumn{4}{c}{ Percentage of population } & \multicolumn{3}{c}{ receiving the benefit } \\
1 & 19 & 50 & 13 \\
2 & 14 & 48 & 8 \\
3 & 12 & 43 & 9 \\
4 & 4 & 34 & 6 \\
5 & 1 & 14 & 3
\end{tabular}

Percentage share of all beneficiaries of programs

\begin{tabular}{lllllrrrrr}
1 & 38 & 27 & 39 & 4 & 42 & 54 & 45 & 25 & 16 \\
2 & 27 & 25 & 21 & 11 & 22 & 21 & 24 & 24 & 16 \\
3 & 24 & 23 & 22 & 21 & 19 & 13 & 16 & 25 & 25 \\
4 & 8 & 18 & 13 & 28 & 13 & 8 & 10 & 16 & 24 \\
5 & 3 & 8 & 5 & 36 & 5 & 4 & 5 & 11 & 19 \\
\hline
\end{tabular}

Source: World Bank (2001). 
the richest quintile. Recently the Thai government planned to expand this program to cover smaller companies having 10 or fewer workers.

\section{Public employment program}

The Social Investment project started in late 1998 with funding from the Thai government and the World Bank, JBIC-Japan, UNDP and AusAID. ${ }^{46}$ Most of the package created jobs through the implementation of small scale civil works. SES (1999) reveals that 1.1 million households were employed on these schemes. Table 5.8 indicates that the program was well-targeted towards the poorer quintiles: 42 percent of the total beneficiaries were from the lowest quintile and only 2 percent of the richest quintile received the benefit.

\section{Free school lunch program and supplementary food programs}

To prevent a decrease in the school enrollment as a result of the crisis, the Ministry of Education established some education assistance programs. The school lunch program is for children in primary school, and the supplementary food or milk program is open to pre-primary and primary students up to third grade. Primarily the idea was to provide food to the undernourished poor school children at primary and pre-primary levels; however, this was later extended to all poor students in primary and preprimary school. ${ }^{47}$ The cost of each meal under this program is pegged at 5 baht, which is a very low amount for a nutritious meal.

SES (1999) reveals that 29 percent of all children aged 6-11 attending primary school benefitted from the school lunch program, while 47 percent of children aged 3-8 benefitted from the supplementary food program. Table 5.8 notes that 45 percent of the children from the bottom quintile received free school lunches and 54 percent of the total beneficiaries come from the poorest quintile. As far as the supplementary food program is concerned, 59 percent of the children are from families belonging to the poorest quintile. Although the program targeted the poor quite well, the arbitrariness in the selection of the poor families meant that not all the needy received the help they required.

\section{Student loan program}

The education loan fund was established in 1996. The target group was students at upper secondary and tertiary level with incomes of less than 12,500 baht per month. SES (1999) notes that the program supported 26 percent of upper secondary school students, 17 percent of the university students and 50 percent of the vocational and technical education students; it also notes that the average age of the recipients is 19 years and 57 percent were women. Table 5.8 shows that the scheme did not reach the 


\section{Income distribution in Singapore and Thailand}

poorest quintile efficiently. Only 16 percent of the total beneficiaries are from the lowest quintile and only 9 percent of the two lowest quintiles received the benefit.

\section{Government scholarship program}

Table 5.8 shows that only 25 percent of the total beneficiaries are from the poorest quintile and 51 percent of all scholarship winners come from the top three quintiles. We have mentioned that the prime determinant of inequality in Thailand is the unequal distribution of education: 90 percent of the university students in Thailand are from the richest quintile. Thus it is observed that both the Student Loan Program and the Government Scholarship Program are poorly targeted.

\section{Conclusion}

The Asian economic crisis created huge job losses in East Asia, particularly in urban areas due to the closures of banks and financial institutions, with repercussions for the rural areas as well. The nominal wage cut and the inflation rate led to a deterioration of the conditions for the low income groups in particular. Income inequality increased to some extent, hiking up the poverty level as well. In Thailand, the income disparity is best explained by the educational disparity. The impact of the crisis was worse on the low-skilled workers and less educated people; regions with a larger concentration of less educated people were badly affected by the crisis. The Thai government's sudden and concerted push towards decentralization further increased the rapid expansion in regional disparity. The impact of income inequality on poverty was four times greater than the impact of reduced growth rate on poverty.

Income inequality increased in Singapore as well, as a result of increased unemployment and a decrease in wage rates. However, the richest quintile saw an increase in salaries, due to a policy to encourage high-skilled expatriate foreign workers, mainly professionals, to remain in Singapore and contribute to the local economy.

Thailand maintained a constant education budget throughout the crisis, while in Singapore some budget cuts were observed in the recurrent expenditures on education. The crisis has not affected the enrollment rate in either country. With respect to the dropout rates, which were expected to increase in Thailand, no conclusive result could be inferred from the available sources of information. It appeared that neither households in Singapore nor in Thailand had actually decreased their education budgets. However, in Thailand, many households chose to switch from private schools to less expensive public schools.

The health sector suffered a budget cut both in Singapore and Thailand. The latter saw the closure of several private hospitals, although the 
government managed to halt any price increases for medicines and drugs. In Singapore, the wage system ensures savings for medical purposes, and there was no change in such savings during the crisis.

The concept of social safety nets has been a part of the World Bank discussions since the late 1980s. In the early 1980 s, the liberalization programs administered by the World Bank and IMF were criticized for placing a burden on low income groups. A prominent feature of the Asian financial crisis is the increasing importance of the concept of social safety nets. In Thailand, it became an important issue, because a very strong local lobby was demanding protective social action during the crisis. Also, Thailand has provided a platform to experiment on such social programs. We have analyzed various Thai schemes for health, social security and pensions, public employment generation, school nutrition programs and education assistance; we concluded that the targeting was not sufficient in several cases. In particular the identification of the needy was arbitrary. It should be noted that the administrative costs involved in the identification and better targeting could be very high. However, it is a topic for future research to investigate whether proper identification is efficient or not.

In Singapore ad hoc policies of income tax rebates on income taxes, public utilities, housing rents etc. did not impact on the income distribution scenario. The government made huge investments on retraining programs for adult workers, benefitting those who had lost their jobs during the crisis. Although there is no abject poverty, the unemployed, the aged, and women in particular, were relatively deprived. The relative deprivation will be felt more keenly when these people observe wealthy people, who did not suffer wage cuts or were not retrenched, in their near vicinity. A wage difference due to skill differences is perfectly understandable, but the income difference caused by the loss of employment is an external shock that causes distress and provokes envy. This may have consequences for the political scenario as well. The Singapore government, thus, might have to consider the concept of social safety nets, at least during the periods of economic downturn that are caused by exogenous factors. The latest Parliamentary debates seem to indicate the status quo. There is much ground to be covered in moving Singapore towards a welfare state, an idea which is anathema to the governing polity.

\section{Notes}

1 Lists of references are found in Goldstein (1998), Lee (1999) among others.

2 See Mukhopadhaya (2001a).

3 World Bank (2001).

4 Mukhopadhaya (2001b).

5 Drop-out rates for primary school aged children fell from 10.3 to 2.3 percent between 1992 and 1997 (NESDB/ADB 1999).

6 Reported in NESDB/ADB (1999).

7 These figures are different from Table 5.1 because of a different definition of 


\section{Income distribution in Singapore and Thailand}

the poverty line. Ahuja et al. (1997) considered a US\$1 poverty line of 1993 PPP-adjusted terms. Thailand's official poverty line was equivalent to the 1993 PPP of US\$1.60.

8 For other poverty studies in Thailand see Booth (1997), Rigg (1998), Kakwani and Krongkaew (2000).

9 For a detailed discussion of the education expenditure, etc., in Singapore see Low et al (1991) and Low (2000).

10 The conditions attached to the World Bank's structural adjustment loans in the wake of the oil crises, and to IMF programs for relieving debt crises, were criticized for creating shocks which were felt most heavily by the poor. In 1990, the UNDP advocated a social approach to development, broader than the narrow focus of the World Bank and IMF on economic stability and growth. By the mid-1990s, the World Bank and the IMF adopted the social policy. It can be observed that Thailand's social expenditure started increasing in 1996, and as the World Bank appreciated the dynamics of economic change and social policies, more funding went for this sector during the crisis period.

11 See Jitapunkul et al. (1999), Reisman (1999), Tangcharoensathien et al. (2000) for further discussion of the Thai health care system.

12 Mukhopadhaya (forthcoming) indicated various problems related to income data of Singapore and calculations of DOS (2000).

13 This observation must be considered with due caution. With the economic downturn, unemployment has been creeping upwards since the second half of 1997. As of June 1998, the overall unemployment rate (non-seasonally adjusted) was 3.2 percent compared with 2.4 percent in June 1997. And in June 1999, the rate was 4.6 percent. It should be noted that workers aged 50 years and older who leave their jobs due to retrenchment or business closures are not counted as unemployed and not part of the labor force. Because of their absence in the data set, the inequality figure has a downward bias.

14 According to the Ministry of Manpower of Singapore, 7,131 people were retrenched in the first quarter of 1998, 7,309 in the second quarter, 6,633 in the third quarter and 8,013 in the fourth quarter. During 1999 the number of retrenched people decreased: 3,402 in the first quarter, 3,350 in the second quarter, 3,395 in the third quarter and 4,475 in the fourth quarter.

15 See Mukhopadhaya and Rao (2002) for inequality and foreign worker issue in Singapore.

16 Phongpaichit and Baker (2000).

17 In a recession period, the real wage typically declines due to a combined effect of the reduced demand for labor and changes in labor supply. There was a large increase in the labor force in the first and second quarters of 1999 when the economy started recovering from the crisis. Thus, although the GDP increased, real wages decreased. There was a huge increase in migrant workers particularly from Myanmar in the post-crisis period as well. The supply of these migrant workers, typically at the lowest-paid job levels, created a downward pressure on real wages.

18 Key Statistics of Thailand (various issues) and Statistical Yearbook (2000) from the National Statistical Office indicate that the increase in food prices was quite substantial, adversely affecting people with low incomes. Prices of medical care and transportation also increased.

19 Isra's (1999) calculation, however, shows a much higher Gini coefficient in the $1990 \mathrm{~s}$.

20 See Warr (2000) also in this respect.

21 There are various government scholarships to expand education (see Mukhopadhaya 2003). 
22 There are eleven vocational training centers run by the Institute of Technical Education (ITE) in Singapore.

23 The Straits Times (8 December 1998).

24 Other relevant factors are unavailability of child care facilities, lack of parttime job opportunities for women, etc. See Mukhopadhaya (2001a) for further details.

25 The poor households in Indonesia reduced their spending on education while no such trend is observed in Korea (Hyunsook 2000).

26 For example, the non-poor households in Indonesia readjusted their budgets by reducing their spending on non-essential items (e.g. recreation, household items, etc.). In Thailand households moved from full-priced private provision to subsidized public provision (Mehrotra 1998). A similar trend is also noticed in the case of the Philippines (Reyes et al. 2000).

27 As mentioned previously, the loss of income can be compensated by earlier savings which minimize the effect on the education sector. In Thailand, it is observed that households finance their education from their savings while in Korea this sort of behavior is absent (Achava-Amrung 2001 and Hyunsook 2000).

28 NESDB/ADB (1999).

29 The government allocated US $\$ 25$ million from budget support provided by the ADB under its Social Sector Program Loan to provide grants to students in primary and secondary schools who were unable to continue their education. According to the ONEC report in early June 1999, over 328,000 students had received approximately 835 million baht.

30 The number of recipients of the Student Loan Program increased from 148,444 to 675,614 in 1996-1998 (Ziderman 1999).

31 Conducted in June 1999. This study is based on three major monitoring and tackling activities supported by the ADB. These include various field surveys, a Brooker group survey and a participatory evaluation exercise conducted by Chulalongkorn University.

32 This has strong implications for the social sector. Poor nutritional intakes by children weaken their immunity to diseases and impair their ability to concentrate and learn.

33 An interesting discussion of the Thai education policies after crisis can be found in Witte (2000).

34 In this respect it should be noted that the MoPH cut its AIDS budget by 24.7 percent in 1998 compared to the 5.5 percent cut for the non-AIDS budget (UNFPA 1999).

35 It is a low-cost catastrophic medical insurance scheme that covers hospitalization expenses, and certain outpatient treatments such as kidney dialysis, chemotherapy and radiotherapy for cancer. The yearly premium is deducted automatically from the member's Medisave account, unless he or she decides not to be insured.

36 This is similar to Medishield but the benefits and the premiums are higher. It allows the member to stay in more expensive wards.

37 For the October-December 2000 period, average payment per claim under

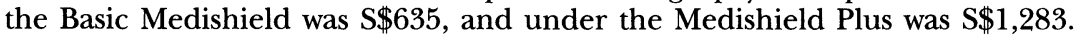
These payments are quite low for catastrophic illnesses requiring hospitalization.

38 In Singapore, CPF contributions are exempted from income tax. The value of the deduction to the CPF contributor depends on the marginal income tax rate applicable. Those outside the individual income tax net, thus, do not get any benefits from the tax deductibility of CPF. For others, the value of the 


\section{Income distribution in Singapore and Thailand}

benefit of the tax deductibility rises with the marginal income tax rate. The tax deductibility feature therefore reduces the degree of progressivity of the income tax.

39 See Robinson and White (1997), Ginneken (1999, 2000, 2001).

40 The Straits Times (1 November 1998).

41 This two-year grant costs the government $\$ \$ 72$ million a year.

42 This rebate costs the government $\$ \$ 40$ million.

43 Those who have depleted the funds in both these accounts can apply to the Bridging Loan Scheme, which provides loans at a concessionary interest rate pegged at the CPF interest rate plus 0.1 percent.

44 A different type of discussion can be found in Tangcharoensathien et al. (1999).

45 The income ceiling is 2,000 baht for a single person and 2,800 baht for a family.

46 The Miyazawa fiscal stimulus package started in April 1999, creating employment for low skilled workers in rural areas, and to some extent for skilled workers in computer-related fields. In total the package provided employment to 88,967 high skilled workers and on average 18 days to 3.5 million unskilled laborers (World Bank 2001).

47 Teachers at the school determine the recipients of this benefit.

\section{References}

Ablett, J. and Slengesol, I. (2000) "Education in crisis: the impact and lessons of the East Asian financial shock, 1997-99", Human Development Network, Washington, D.C.: The World Bank.

Achava-Amrung, Pronchulee (2001) "Impact of economic crisis on higher education institutions in Thailand", draft report presented at UNESCO Policy Forum on Economic Crisis and Higher Education in East Asia, Kuala Lumpur, Malaysia, 29-31 January.

ADB (various years) Key Indicators of Developing Asian and Pacific Countries, Manila: Asian Development Bank.

Ahuja, V., Bindani, B., Ferreira, F. and Walton, M. (1997) Everyone's Miracle? Revisiting Poverty and Inequality in East Asia, Washington, D.C.: The World Bank.

Asher, M.G. and Karunarathne, W. (2001) "Social security arrangements in Singapore: an assessment", paper presented at International Seminar on Pensions, Tokyo, 5-7 March.

Booth, A (1997) "Rapid economic growth and poverty decline: a comparison of Indonesia and Thailand 1981-1990", Journal of International Development, 9(2): 169-187.

CPF (various years) CPF Board Annual Report, Singapore: Central Provident Fund.

DOS (1997/1998) Household Expenditure Survey, Singapore: Department of Statistics. (2000) "Is income disparity increasing in Singapore?" occasional paper on Social Statistics, Department of Statistics, Singapore, May.

- (various years) Yearbook of Statistics, Singapore: Department of Statistics.

Ginneken, W. van (ed.) (1999) Social Security for the Excluded Majority, Case Studies of Developing Countries, Geneva: International Labour Organization.

(2000) "The extension of social protection: ILO's aim for the years to come",

in T. Conway, A. de Haan and A. Norton (eds) Social Protection: New Directions of 
Donor Agencies, London: Department for International Development, Social Development Department.

- (2001) "Social protection for workers in the informal economy: new challenges for Asia and the Pacific", in Towards More Effective Social Security in Asia and the Pacific, Asia and Pacific Series, Social Security Documentation No 26, Manila: International Social Security Association.

Goldstein, M. (1998) The Asian Financial Crisis: Causes, Cures, and Systematic Implications, Washington, D.C.: Institute for International Economics.

Government of Singapore (various years) The Budget, Singapore: Government of Singapore.

Hyunsook, Y. (2000) The Economic Crisis and Higher Education: The Korean Case, Paris: International Institute for Educational Planning/United Nations Educational, Scientific and Cultural Organization.

Isra, S. (1999) "Growth, structural change and inequality: the experience of Thailand". Online. Available at: <http://www.oecd.org/dev/ENGLISH/pagelisteE/Poverty-Ineq/Documents/> (accessed 20 September 2001).

Jitapunkul, S., Songkhla, M.N., Chayovan, N., Chirawatkul, A., Choprapawan, C., Kachondham, Y. and Buasai, S. (1999) "A national survey of health service use in Thai elders", Age and Aging, 28: 67-71.

Kakwani, N. (1998) Impact of Economic Crisis on Employment, Unemployment and Real Income, Bangkok: National Economic and Social Development Board.

- (2001) "Pro-poor growth and policies", paper presented at the ADB Annual Meeting Seminar on "Pro-Poor Growth: The Renewed War on Poverty", Honolulu, Hawaii, 8 May.

Kakwani, N. and Krongkaew, M. (2000) “Analyzing poverty in Thailand”, Journal of Asia Pacific Economy, 5(12): 141-160.

Lee, E. (1999) The Asian Financial Crisis: The Challenge for Social Policy. Geneva: International Labour Organization.

Lim, C.Y. and Tay, B.N. (1991) "Shelter for the poor: housing policy in Singapore", Asian Development Review, 9(1): 90-110.

Low, L. (2000) Education Skills Training and National Development: Experience and Lessons from Singapore, Tokyo: Asian Productivity Organization.

Low, L., Heng, T.M. and Wong, S.T. (1991) Economics of Education and Manpower Development: Issues and Policies in Singapore, New York and Singapore: McGraw-Hill.

Mehrotra (1998) "Thailand: education achievements, issues and policies", World Bank Report No 18417-TH, The World Bank.

Ministry of Manpower (1999) Reports on the Labor Force Survey of Singapore, Singapore: Manpower Research and Statistics Department, Ministry of Manpower.

- (2001) Singapore Yearbook of Manpower Statistics, Singapore: Manpower Research and Statistics Department, Ministry of Manpower.

Mokoro (1999) "Thailand public expenditures review", report prepared for the Bureau of the Budget, Government of Thailand, February.

Mukhopadhaya, P. (2001a) "Changing labor force gender composition and male female income diversity in Singapore”, Jourmal of Asian Economics, 12: 547-568.

- (2001b) "Distribution of income and expansion of education in some East Asian countries”, Journal of Interdisciplinary Economics, 12: 327-357. 


\section{Income distribution in Singapore and Thailand}

- (2003) "Trends in income disparity and equality enhancing (?) education policies in the development stages in Singapore", International Journal of Educational Development, 23: 37-56.

- (forthcoming) "Income disparity in Singapore: trends, data problems and policy issues", International Journal of Social Economics.

Mukhopadhaya, P. and Shantakumar, G. (2000) Economic Crisis and Higher Education in Singapore, Paris: International Institute for Educational Planning, United Nations Educational, Scientific and Cultural Organization.

Mukhopadhaya, P. and Rao, V.V. Bhanoji (2002) "Income inequality", in A.T. Koh, K.L. Lim, W.T. Hui, B. Rao and M.K. Chng (eds) Singapore Economy in 21st Century, Singapore: McGraw-Hill.

Na Songkhla, M., Wibulpolprasert, S. and Prakongsai (1999) "Good drugs at low cost: Thailand's provincial collective bargaining system for drug procurement", Essential Drug Monitor, 25-26: 6-7.

NESDB (1999) Indicators, 3(3), Bangkok: National Economic and Social Development Board.

NESDB/ADB (1999) Indicators of Well-being and Policy Analysis: Education in Transition: Thailand's Case, 3(2) April (TA No. THA 29614) Bangkok: National Economic and Social Development Board and Asian Development Bank.

NSO (various years) Key Statistics of Thailand, Bangkok: National Statistical Office.

- (various years) Socio Economic Survey (SES), Bangkok: National Statistical Office.

(1994, 1996, 1998, 1999, 2000) Household Socio-economic Survey, Bangkok: National Statistical Office.

(2000) Statistical Yearbook 2000, Bangkok: National Statistical Office.

ONEC (1999) "Estimates of school dropouts in 1998", report, June 1999, Bangkok: Office of National Education Commission.

Phokpermdee, P., Wongwatcharapaiboon, P. and Intasuwan, N. (1999) "The situation of community hospital doctor, September 1999”, Community Hospital Journal, 4: 31-34.

Phongpaichit, P. and Baker, C. (2000) Thailand's Crisis, Singapore: Institute of Southeast Asian Studies.

Reisman, D.A. (1999) "Payment for health in Thailand", International Journal of Social Economics, 26(5): 609-641.

Reyes, C.M., de Guzman, G.G., Manasan, R.G. and Orbeta, A.C. (2000) "Social impact of regional financial crisis in the Philippines", paper prepared for the Asian Development Bank.

Rigg, J. (1998) "Tracking the poor: the making of wealth and poverty in Thailand (1982-1994)", International Journal of Social Economics, 25(6-8): 1128-1141.

Robinson, M. and White, G. (1997) The Role of Civic Organizations in the Provision of Social Services, Towards Synergy, Research for Action 37, World Institute of Development Economic Research, United Nations University, Helsinki.

Socio Economic Survey (SES) (various years) Bangkok: National Statistical Office.

Sauwalak, K. and Chettha, I. (1999) Adjustment of the Thai Labor Market in the Crisis, Bangkok: TDRI.

Tangcharoensathien, V., Harnvoravongchai, P., Pitayarangsarit, S. and Kasemsup, V. (2000) "Health impacts of rapid economic changes in Thailand", Social Science and Medicine, 51: 789-807. 
Tangcharoensathien, V., Supachutikul, A. and Lertiendumrong, J. (1999) "The social security scheme in Thailand: what lessons can be drawn?", Social Science and Medicine, 48: 913-923.

The Straits Times (1 November 1998) Singapore.

The Straits Times (8 December 1998) Singapore.

UNDP (2000) Human Development Report, New York: United Nations Development Programme and Oxford University Press.

UNESCO (various years) Statistical Yearbook, Paris: United Nations Educational, Scientific and Cultural Organization.

UNFPA (1999) Press Release, United Nations Population Fund. Online. Available at: <http://www.unfpa.org/news/pressroom/1999/se-asia.htm> (accessed 22 March 2001).

Warr, P.G. (2000) "Is growth good for the poor? Thailand's boom and bust", International Journal of Social Economics, 27(7-10): 862-877.

WHO (1998) "Health implications of the economic crisis in the South-East Asia region", report of a Regional Consultation, Bangkok, Thailand, 23-25 March, New Delhi: World Health Organization. Online. Available at: <http://www. worldbank.org/capsocial/partnees/who.htm> (accessed 3 April 2001).

Wibulpolprasert, S. (1999) "Globalization and access to essential drugs: case study from Thailand", paper presented at the meeting on "Globalization and Access to Essential Drugs", Amsterdam, 25-26 November.

_ (2002) "Health care system in Thailand", in Health Insurance System in Thailand, German Foundation of International Development, Health Insurance Office, Thailand, and Health Insurance Research Institute, Thailand.

Wibulpolprasert, S. and Pengpaiboon, P. (2001) "Economic dynamics and health: lessons from Thailand", Development, 44(1): 99-107.

Witte, J. (2000) "Education in Thailand after the crisis: a balancing act between globalization and national self-contemplation", International Jourmal of Educational Development, 20: 223-245.

Wongwatcharapaiboon, P., Sirikanokwilai, N. and Pengpaiboon, P. (1999) "The 1997 massive resignation of contracted new medical graduates from Thai Ministry of Public Health: what reasons behind", Human Resources for Health Development Journal, 2: 147-156.

World Bank (1993): The East Asian Miracle: Economic Growth and Public Policy, Washington, D.C.: The World Bank.

— (1997) World Development Report, 1997, Washington, D.C.: The World Bank. (1999) "Thailand social monitor: coping with crisis in education and health", The World Bank. Online. Available at: <http://www.worldbank.or.th/cgibin/load.cgi?social/pdf/social-part i \& ii.pdf, since May 1999> (accessed 3 March 2002).

- (1999/2000) World Development Report, 1999/2000, Washington, D.C.: The World Bank.

(2000/2001) World Development Report, 2000/2001, Washington, D.C.: The World Bank.

— (2000) World Development Indicator CD ROM, Washington, D.C.: The World Bank.

(2001) "Thailand social monitor: poverty and public policy", The World Bank. Online. Available at: < http://www.worldbank.or.th/cgi-bin/load.cgi?social/ pdf/FinalSMV1.pdf, Since November 20, 2001> (accessed 2 March 2002). 


\section{Income distribution in Singapore and Thailand}

World Bank Thailand (2000) Thailand Social Monitor: Social Capital and the Crisis, Bangkok: The World Bank.

Ziderman, A. (1999) "The student loan scheme in Thailand: a review and recommendations for efficient and equitable functioning for the scheme", report prepared for UNESCO, Bangkok as part of the ADB Social Sector Program Loan. 


\title{
6 Effects of a crisis? Institutional adjustment and pro-poor growth in Thailand ${ }^{1}$
}

\author{
Pernilla Sjöquist Rafiqui and Örjan Sjöberg
}

\section{Introduction}

To the social scientist, perhaps the most eye-catching accomplishments of the East and Southeast Asian countries over the past few decades are an enviable record of economic growth, and the changes that this has wrought. Not least worthy of note is the fact that the great majority of the inhabitants of the countries concerned have been able to share the fruits of growth. "[R]apid growth and reduced inequality". The World Bank (1993: 27) noted about a decade ago, "are the defining characteristics of what has come to be known as the East Asian economic miracle". In most countries not only have the poor as a share in the total population diminished, the absolute number of poor has declined as well (e.g. Ahuja et al. 1997).

As a result, the enabling policies of the East and Southeast Asian economies have attracted much attention, as have the institutions that these countries based their economic activities on. While there has been little agreement on the exact nature of these policies and institutions, nor for that matter on the role of politicians and other stakeholders shaping or influencing it, it is fair to say that, as the process of economic development unfolded, less attention came to be devoted to the obstacles and constraints that were also part of the picture. The crisis of 1997 proved instrumental in changing this focus on the positive lessons to be learnt.

Across the region, the crisis resulted in substantial reductions in real output and challenged the pattern of high economic growth that many observers had come to take for granted. In particular, it revealed various structural and institutional weaknesses among the countries most severely hit, Thailand and Indonesia being two cases in point. It comes as no surprise therefore that the debate has been intense.

One strand of this debate has focused on the reasons why the crisis came about in the first place. The natural focus has been on institutions and structural arrangements at the macro or policy level. Institutional structures relating to financial markets, issues of corporate governance and the nature of corporate-government relations, and the lack of democratic 
self-correcting mechanisms are a few examples. Important questions include the extent to which such variables can explain if not the arrival of the crisis, then at least its impact on and consequences for economic growth.

The negative effects on economic growth have also led to a second and equally important strand of the discussion, that is, the impact of the crisis on poverty and unemployment in the region. Even though the gains from economic growth since the beginning of the Asian miracle have not been wiped out by the 1997 crisis, the social impact of the crisis has been substantial (Warr 2000a). Initially, the impact on the number of people who live below the poverty line was central to this debate, and much effort has been put into estimating and evaluating the effects of the crisis in terms of numbers and head counts. Preliminary findings indicated that the oftentimes very gloomy predictions for Indonesia, Thailand and Malaysia have (fortunately) not been met (e.g. Jones et al. 2000), even though the number of poor people increased by several percentage points compared to 1996 in all three countries.

Booth (1999) argues that this is due to poverty estimates being driven primarily by changes in real consumption expenditures, while the first round of findings indicate that the serious reduction in GDP will have a greater effect on investment rather than on consumption expenditure. Moreover, available evidence points to the crisis having affected various groups of poor people differently, one big discrepancy being between rural and urban areas. Data from Indonesia and Thailand identify regions specializing in cash crop production for export as having gained from the devaluation of the rupiah and the baht. However, increases in nominal income in rural areas have partly or fully been offset by increased costs of living, at least in the case of Indonesia. High inflation in the aftermath of the crisis in Indonesia has adversely affected the poor since food prices have risen faster than other prices. Some studies argue that inflation is the cause of much of the increase in number of people below the poverty line in Indonesia, while for Thailand, Malaysia and South Korea, rising unemployment has been the main source (e.g. Lee 1998; cf. Warr 2000a); it can be noted, however, that also in face of rapidly increasing inflation, nominal money wages for unskilled workers decreased as result of the crisis (Warr 2001: 119).

This has of course been widely understood in the countries so affected and measures have been taken to rectify the problems encountered. As a result, the discussion on the effects of the crisis on poverty has been broadened somewhat to incorporate the social impact of the Asian crisis in terms of education and health care, as well as poverty alleviation strategies and social security provision. Evidence so far indicates that school drop-out rates increased in Indonesia and that concerns over poor families taking children out of school to economize on school fees and other related costs may be well founded. For Thailand some observers argue 
that the loss of job opportunities for unskilled young people in construction and manufacturing has rather led to a net increase in school enrollment in that country (Booth 1999). Indonesia, worried over the effects of a drought that coincided with the crisis, rushed to implement a number of food-for-work programs, making use of administrative procedures that were already in place. These have largely been deemed unsuccessful in reaching the poor, but had the benefit of bringing the issue of social insurance networks for poor people to the forefront of the policy agenda.

Unfortunately, the analysis regarding poverty often stops at evaluating government-induced employment programs and emergency assistance projects that were launched in response to the crisis. In particular, there is so far little in the literature on the impact of institutional reforms implemented at the macro level on the constraints and incentives facing the poor at the micro level. It may very well be the case that unless poverty alleviation was part of the reform design, poor people in Southeast Asia are just as vulnerable to major shocks to the economic system today as they were before the crisis.

The present chapter aims to examine the consequences and effects of institutional changes made in response to the Asian Crisis of 1997 on the poor of Southeast Asia. Indeed, can institutional change be seen to address the needs of pro-poor growth at all? Using a framework inspired by institutional analysis, we attempt to shed light on the constraints on the capabilities of poor people. As institutions and the context (history, policies, contingencies) that shape them are typically national in scope, we shall illustrate this by recourse to a case study on one of the countries most severely affected by the crisis, Thailand.

\section{Institutional analysis and pro-poor growth}

\section{Institutions change}

Even a superficial acquaintance with economics will reveal that the institutional framework as an analytical category is gaining ground. It is evident not least from the growing body of work investigating the relationship between institutions and economic development (Lin and Nugent 1995). This has been triggered by a number of recent events. One is the disappointment with many structural adjustment programs in Africa and elsewhere; whatever their merits, they simply do not compare well with developments in regions where economic growth has been successfully achieved, the economic boom of the so-called Asian Tigers prior to 1997 being the most prominent example. Although attempts were made to accommodate the Asian experience with the ideas underlying structural adjustment programs, perhaps most prominently in the World Bank's The East Asian Miracle (1993), the Asian experience with high and sustained economic growth provided a forceful rationale for bringing up issues such 
as legal structures, policies and value systems rather than maintaining an exclusive focus on deregulation and price reform. Other events, such as the collapse of the Soviet Union and the emergence of China as a major economic power, also served to underline the importance of not only macro-economic stability, but also the institutional set-up of economies. Not least, and somewhat paradoxically, the Asian financial crisis of 1997 revealed the necessity to seriously consider the institutional underpinnings of market based economies. As Rodrik (2000: 4) puts it, "[t]he question before policy makers therefore is no longer 'do institutions matter?' but 'which institutions matter and how does one acquire them?'”.

Although a consensus of sorts on the importance of institutions has emerged among economists and, more broadly, among social scientists, there are still several question marks. From the point of view of research, as opposed to policy and application, the difficulty of connecting theory to empirical outcomes has proved to be a major stumbling block. One reason for this is the very nature of the concept itself; it is not particularly precise, and efforts to address this lack of precision as likely as not reduce not only its scope, but also its applicability.

It is nevertheless useful to introduce some basic distinctions. Institutions, broadly speaking, are in this chapter thought of as the existence of a number of written and unwritten behavioral constraints that together make up the societal context within which people interact and make decisions. One useful definition reads:

[A] set of humanly devised behavioral rules that govern and shape the interactions of human beings, in part by helping them to form expectations of what other people will do. In so constraining behavior, institutions may be reflected in the appearance of certain behavioral regularities or norms.

Lin and Nugent (1995: 2306-2307)

Lin and Nugent make a further useful conceptual distinction between institutional arrangements and institutional structure. The former refers to "a set of behavioral rules governing a specified domain", while the latter is used to cover "the totality of institutional arrangements in an economy, including its organizations, laws, customs, and ideology" (Lin and Nugent 1995: 2307). Moreover, they claim that the term institutional change usually refers to a change in one institutional arrangement, rather than to a change in all arrangements in the structure. However, since there is usually a high degree of dependency between institutional arrangements, institutional change in one domain may very well be affected by, or affect, other institutional arrangements. Arguably the Asian crisis, with its initial and often exclusive focus on institutions supporting the financial market, is an example of this.

The definition of institutions as behavioral rules may at first seem quite 
removed from the every day use of the term, which usually refers to wellestablished and important organizations (or people) in society. Yet the term frequently refers to an organization plus "something more", where the "something more" part tries to capture the structural importance of the organization in question. Financial institutions or various legal and governmental institutions may serve as examples. In real life there is a high degree of interdependence between institutions and organizations as both provide structures to human interaction. But, as argued by North (1990), conceptually the two are very different and in order to understand economic growth, in particular long-term growth, it is important to keep them apart.

In line with the definition above, North lets the term "institutions" refer to "the humanly devised constraints that shape human interaction" or in short, the rules of society. These can be formal, such as written policies, laws and regulations, or informal, such as customs, traditions and conventions. "Organizations", on the other hand, denote "groups of individuals bound by some common purpose to achieve objectives". ${ }^{2}$ Using an analogy to the world of sports, he lets "institutions" indicate the rules of the game, and "organizations" represent the teams or players that play the game (North 1990: 5). ${ }^{3}$

Given the significance of institutions as an explanatory variable for economic growth, it becomes important to understand how they change and evolve over time. Here North argues that it is essential to try to discern the rules governing a situation (i.e. the institutional framework) from the strategies of the players in it (i.e. the interests and actions of the organizations). The process of institutional change can, in a simple fashion, be described as a bargaining process in which the party (individual, groups of individuals, organizations) who stands to improve his or her position if the institutional arrangement is altered may very well set aside resources to attempt to do so (North 1990: 86). Relative price changes and changes in preferences are, according to North, the basic sources of institutional change, that is, the re-negotiating process over the prevailing institutional arrangement.

\section{Institutions and policy}

Even though this might sound straightforward enough, it is potentially a rather complicated story. The costs associated with institutional change, in economic, social and political terms, are in most cases substantial. A complex web of formal rules vested in a hierarchy, where each level is more costly to change than the previous one, and informal constraints with a persistent ability to survive, as they have become part of habitual behavior, help to stabilize the institutional framework. What is more, given the process of negotiation, agents with strong interests will put substantial resources into securing the structure that fits them the best. 


\section{Thai institutional adjustment and pro-poor growth}

Hence, there is nothing in the way institutions emerge and evolve that ensures allocative efficiency in the resulting institutional arrangement. One possible result may be a pattern of institutional change characterized by "institutional lock-in", in which inefficient institutions (e.g. property rights) survive even in the long run. In short, the distinction between institutions and organizations exposes a pattern of interaction between the two that impacts the direction of institutional change.

From a policy perspective, the story is much the same. We have to distinguish between the policies that are aimed at changing or adjusting institutions from those that are not. The latter, however, may influence not only organizations but also the long-term viability of institutions. What is more, policies may or may not be implemented in the manner intended, and outcomes may, as a result, differ from those anticipated or hoped for. Such differences may depend on which type of policies, or the type of institutions, that are in focus.

In fact, distinguishing between institutions that are operational at the macro-economic level and those that address micro-economic issues proves useful (Rodrik 2000). As indicated in Figure 6.1, the former may include policy measures introduced to improve, change or safeguard sound macro-economic development. The latter are those that are addressed to the smooth running of markets, for instance property rights, competition policy or measures directed at other forms of market failures. Also industrial policies would find their way into this category.

Both sets of policies aimed at institutional adjustment are national in scope. National policies, however, do not necessarily result in nationally homogeneous and consistent implementation, nor in nationally homogeneous outcomes. We would therefore need to consider also developments at a sub-national level where not only the locally or regionally differentiated implementation or outcomes can be assessed, but also contingency and context can be accommodated. Indeed, some of the phenomena that Rodrik includes under his micro-economic heading, such as local knowledge, are best considered here.

A few additional comments on Figure 6.1 are in order. The local/regional scale can also be conceived of in terms of individuals, households or communities (as does, for instance, Booth 1999). In the micro column, that is, in the lower right panel, this can be translated into livelihoods, participation and strategies, none of which is particularly amenable to generalization. Consider, for example, the fact that the peoples of northern Thailand were long denied Thai citizenship, such that they were "unable to travel beyond the district and therefore denied the opportunity to search for work" (Rigg 1997: 119). Although this was by no means the norm for Thailand, it was a powerful mechanism of exclusion for entire communities in some parts of the country. Although to the analyst such variation across the national landscape comes at a cost, namely at the cost of the ability to generalize, a focus on the micro level 
Economic policies

$\begin{array}{llll} & \text { Macro-economic } & \text { Micro-economic } \\ \text { Scale of Analysis } & \text { National } & \begin{array}{l}\text { Fiscal, monetary } \\ \text { policy and associated } \\ \text { institutions }\end{array} & \begin{array}{l}\text { Regulatory policies } \\ \text { Industrial policy }\end{array} \\ & \begin{array}{l}\text { Local/ } \\ \text { Regional }\end{array} & \begin{array}{l}\text { Implementation } \\ \text { and/or outcomes } \\ \text { (including actions } \\ \text { taken) }\end{array} & \begin{array}{l}\text { Implementation } \\ \text { and/or outcomes } \\ \text { (including actions } \\ \text { taken) }\end{array}\end{array}$

Figure 6.1 Institutions, policies and outcomes.

affords the benefit of assuming a bottom-up perspective. On the other extreme, it is in the upper left panel of Figure 6.1 that the "blueprints"approach to the acquisition of institutions (Rodrik 2000) is possible; already as we move to the upper right hand panel, context and contingency - now in the form of the nationally specific - threaten to get in the way of a "clean" implementation process. It is at the grass roots level, however, that this difficulty of generalization is the most likely to be of concern to the analyst.

\section{An institutional approach to pro-poor growth}

Lin and Nugent (1995: 2307ff) argue that institutions perform two basic functions in the economic system: an economizing function and a redistributive function. The economizing function aims at Pareto improvements through the means of production enhancements (by taking advantage of internal and/or external economies of scale, and specialization), the collection of more and better information, and risk reduction. Property rights arrangements are prominent among economizing institutions.

The re-distributive function addresses the non-neutrality of economizing property rights with respect to the allocation of gains from specialization and exchange. The re-distributive function may be a primary function or motive for many institutional arrangements, and it may or may not include the poor. Moreover, if the distribution of the power to impose rules is highly skewed and there are few alternative institutional arrangements, it may very well dominate the economizing function. Thus, to the extent that pro-poor growth is about achieving economic efficiency gains while assuring that these gains also benefit the poor, institutions are at the heart of the subject.

What are the implications of such a line of reasoning? For now, suffice 


\section{Thai institutional adjustment and pro-poor growth}

it to note that an institutional approach lifts into the foreground the formal and informal behavioral constraints that limit the action space of poor individuals. It thus helps in setting the poor at the center of a systematic contextual analysis. In this regard the institutional paradigm is close to the manner in which scholars have thought of livelihoods. Livelihoods focus on the set of assets (financial, real and human) available to the individual, the strategies of combining those adopted by the individual, and the outcome of the resulting livelihoods. The institutional framework is essential in determining both constraints in the form of availability of assets, but also in the sense of imposing limits on the strategy set of the poor. In addition, their ability to influence the institutional arrangements, by way of established democratic processes or other means, should not be entirely discounted, but is often also restricted in part for reasons to be found in the institutional structure of the country, or the institutional arrangements in the domain of political decision making.

For instance, taking a cue from North (1990), the poor are vulnerable to relative price changes, and usually lack voice or representation in the negotiation process. Their influence on institutional change, particularly of formal institutions, is thus limited. Mass movements and demonstrations in response to price changes of food are an example where they can have voice. Continuing such a Hirschmanian line of reasoning, there is also the option of exit, whether it implies migration or a withdrawal into (agricultural) subsistence activities. From this point of view, migration as a behavioral response to a shock under a given set of institutions conceived as constraints may or may not be beneficial, but withdrawal into self-sufficiency is decidedly not beneficial to society.

Research indicates that the role of the state and non-government organizations (NGOs) in the lives of the poor is limited, and that the poor mostly rely on informal networks for their survival and security. This implies that the formal institutional set-up may be of less direct importance (or less of a hindrance?) to the poor than are informal institutions such as social norms and customs, as well as informal organizations, none of which are easily assessed at the national level. There are also areas where formal institutions may have a negative impact, including land laws, credit laws and inheritance laws.

In sum, the above pointers suggest we should focus on policies that bring about change or adjustment in existing institutional arrangements, and perhaps also those that have an impact, if any, on the overall institutional structure. But to stop at institutional change per se would be to miss the point of the framework outlined above. Institutional change congruent with the notion of pro-poor growth should allow the poor to share the benefits of economic efficiency gains achieved through that change. In principle, this can be done either through redistribution of the gains from growth, or by recourse to institutional adjustment that make the poor an integral part of the process of enhancing efficiency; if the thinking of Sen 
(1999), focusing on capabilities and freedoms, is taken seriously, the latter of these two options is much to be preferred. Similarly, policies that are not economically sustainable may serve important short-term ends, but should be identified as such; this is because a lack of sustainability in this sense may in fact bring additional hardship to vulnerable groups. Expansionary macro-economic policies, if carried too far, are likely to generate negative effects that are more difficult for the poor to weather or compensate for than for the more affluent groups of society. This could be the case, for instance, if the policies result in high levels of inflation, which tend to have distributional consequences biased against the poor.

\section{The case of Thailand}

\section{From success to failure - and back?}

Few countries have enjoyed such a period of growth as did Thailand during the decades leading up to the Asian crisis of 1997. While the undeniable economic success, as Warr $(2000 \mathrm{~b}, 2001)$ has pointed out, arguably also contained the seeds of its own destruction, the rapid growth of GDP translated into considerable improvements in incomes across wide segments of society. This can be seen from Table 6.1. The exact nature of these improvements, however, is not equally obvious. If one argues, as does Kakwani (2001), that "pro-poor growth" is growth that benefits the poor proportionally more than the rich and "trickle-down growth" is growth that benefits the poor but proportionally less than the rich, then Thailand in the period 1988-1998 can be characterized by trickling-down growth. This is so both in terms of headcount ratio as well as poverty gap and severity of poverty ratios. ${ }^{4}$ Other researchers have come to similar conclusions: although GDP growth has had a noticeably positive impact as far as poverty reduction is concerned, in Thailand this has been combined with increasing income inequality (Warr 2001, Deolalikar 2002, Medhi and Kakwani 2003).

As long as labor supply was plentiful, as was the case up to the late 1980 s, real wages remained relatively stable, but the wage income became available to a rapidly increasing number of people. By the early 1990s, however, the labor supply became increasingly inelastic and in response, real wages began to increase at much higher rates than in the past. The consequences were soon to be seen and labor-intensive export production suffered from the increasing costs; by 1996 there was a sizeable decline in exports of garments, footwear and textiles as Thailand began to price itself out of those markets (Warr 2000b).

Predictably, job creation in these industries began to stagnate and soon jobs were shed. But worse was to come. Once the crisis struck, employment in other sectors was similarly affected. The very substantial depreciation did little, at least initially, to reverse the trend of the declining job availability. Also activities that would appear to gain from a realignment of 
136 Thai institutional adjustment and pro-poor growth

Table 6.1 Some historical socio-economic indicators for Thailand

\begin{tabular}{|c|c|c|c|c|c|}
\hline & $1961-1970$ & $1971-1980$ & $1981-1990$ & 1991-1996 & $1961-1996$ \\
\hline GDP growth (\%) & 8.17 & 6.89 & 7.89 & 8.05 & 7.75 \\
\hline \multirow{2}{*}{$\begin{array}{l}\text { GNP per capita } \\
\text { growth }(\%)\end{array}$} & 5.41 & 3.90 & 5.95 & 6.49 & 5.44 \\
\hline & 1960 & 1970 & 1980 & 1990 & 1995 \\
\hline \multirow{2}{*}{$\begin{array}{l}\text { GNP per capita } \\
\text { (1995 US\$) }\end{array}$} & 451 & 762 & 1,115 & 1,977 & 2,771 \\
\hline & & & 1975 & 1985 & 1995 \\
\hline \multirow{2}{*}{$\begin{array}{c}\text { Less than US\$1 } \\
\text { per day }(\%)\end{array}$} & & & 8.1 & 10.0 & $<1.0$ \\
\hline & 1962 & 1969 & 1975 & 1986 & 1992 \\
\hline \multirow[t]{2}{*}{ Gini coefficient } & 0.41 & 0.43 & 0.42 & 0.47 & 0.52 \\
\hline & 1975 & 1980 & 1985 & 1990 & 1995 \\
\hline $\begin{array}{l}\text { Human } \\
\text { Development } \\
\text { Index, } \mathrm{HDI}^{a}\end{array}$ & 0.603 & 0.645 & 0.675 & 0.713 & 0.749 \\
\hline
\end{tabular}

Source: Quibria (2002), Deininger and Squire (1996a, 1996b), UNDP (2001).

Note

a A country is classified as having achieved high human development if it scores an HDI of 0.800 or above; medium human development if the HDI is $0.500-0.799$; or low human development if the HDI is less than 0.500 .

the exchange rate suffered, as uncertainty and a drying up of credit also hit export producers who therefore found it difficult to respond by increasing output.

One effect of these developments was a reversal of the migration to the main industrial areas, affecting the Bangkok metropolitan area in particular (Sutham 2000). Yet, because of changes in the manner in which agricultural production was organized, the traditional employment buffer of the economy was not able to absorb those released from urban jobs in the manner it had done in the past. The expansion of export production and modern agri-businesses has led to the increasing marginalization of traditional agriculture. Cropping patterns have changed, as well as the techniques used. Traditional methods of production have been made to yield to those that are less dependent on labor input; predictably, if somewhat ironically, as the call from urban areas and jobs available there had been heard and responded to, agriculture found itself fighting an uneven battle against an increasing lack of labor. For instance, in Thailand's "rice bowl", the Chao Phraya delta, transplantation as a technique of rice cultivation was made to yield to broadcasting in the 1970s and 1980s, while in parallel, pluri-activity became the standard strategy for generating income in rural households if outright specialization and large scale farming were 
not feasible (Hanks 1972, Molle and Thippawal 2003). The obverse of this is that access to land no longer serves as a good predictor of income, an observation that by the 1980 s also could be extended to areas less favored than the plains of Central Thailand (Rigg 1988). Indeed, a decade later it "has become increasingly evident ... that it is no longer possible to assume that rural livelihoods depend on agriculture" (Rigg 1998: 1135).

For these and other reasons many remained in urban areas when unemployment soared. The rise in urban unemployment was linked to an increase in informal sector activities and a range of social problems primarily associated with low or no income. Unemployment in urban areas was paralleled by underemployment in rural areas. Those fortunate enough to retain their jobs found that their real incomes decreased as inflation shot up. The average income decreased by a substantial percentage - real incomes are believed to have decreased on average by 10-20 percent - and millions of Thais were added to those already below the poverty line. The exact numbers, however, have not been that easy to establish.

Authoritative sources suggest that the headcount ratio for Thailand shows a drop from more than 50 percent of the Thai population living below the national poverty line in the early $1960 \mathrm{~s}$, to 32.6 percent in 1988 to a "mere" 11.4 percent in 1996, the year before the crisis (Kakwani 2001). The 1998 Socio-Economic Survey reveals that the share of the population living below the national poverty line in that year had increased to 12.9 percent. In real terms this translates to an increase in the number of poor from 6.8 million to 7.9 million between the two years, an increase of 1.1 million people or 16 percent. Moreover, Kakwani estimates that the impact of the crisis has been worse on the "ultra-poor" (incomes below 80 percent of the poverty line) compared to the "marginally poor" (incomes between 80 and 100 percent of the poverty line) and the "nearly poor" (incomes within 100-120 percent of the poverty line). The number of ultra-poor increased by 16.6 percent between 1996 and 1998, and they then constituted some 54 percent of the poor population and 7 percent of the total population of Thailand. The number of marginally poor increased by 11.3 percent, and the nearly poor by 3.9 percent (cf. UNDP 1999). The estimate for 1999 is 15.9 percent or approximately 9.8 million Thais living in poverty at the end of the millennium (ADB 2001c). If this estimate holds true, the Asian crisis succeeded in pushing about 3 million people below the poverty line within two years of its eruption. All in all, Kakwani (2001) found that the crisis adversely affected the poor proportionally more than the rich, but that the relative disadvantage of the poor during the crisis seems less than in the preceding high growth period. In other words, the rich lost out on some of their lead position visà-vis the poor in terms of income as a result of the crisis.

This does not tally in all respects with the results arrived at by another knowledgeable observer, Warr (2000b: 872), who suggests that the incidence of poverty over the period 1996-1998 increased from about 8 to 22 
percent of the population; this implies that more than 8 million people were pushed below the poverty line and that all gains in poverty reduction since 1986 were lost. This represents something of an upper bound estimate, however, and the same author at about the same time also supplied a much more conservative increase of combined urban and rural poverty from 6.25 percent in 1996 to a predicted 9.28 percent in 1998. This implies that some 2 million people were added to the poor (Warr 2000a: 440). Far less depressing as this latter estimate is, the fact remains that the considerable gains made during the period of high growth were in part lost because of the events of 1997. No matter which one of the three above estimates is closest to the truth, as Kokko (1999: 1) notes, the crisis "reintroduced poverty as a major development problem".

A return to economic growth is at the heart of the solution to that problem. Warr (2000b: 872) notes that according to data available at the end of the 1990s, the rate of growth required in order simply to remain at the then current level of poverty incidence is 6 percent or more. Yet the possibility of returning to the growth trajectory, on which Thailand found itself prior to the crisis, appears slim. As revealed by Table 6.2, in the postcrisis period, real growth hovered around 5 percent a year, except in 2001 , when it was substantially lower. Thus, while the Thai economy definitely has held up fairly well as far as the numbers are concerned, the fall in GDP growth after the crisis constitutes the most severe threat to continued reduction in poverty in the future (see e.g. UNDP 1999, Kakwani and Krongkaew 2000, Warr 2000b, Quibria 2002).

What the data suggest is that Thailand is no longer in a position to compete on the world market in the manner it did during a substantial part of the post-war period. Instead, it has to move up the value-added ladder, which in turn implies that education, never the strongest part of the Thai development policies, will be critical in any process of sustainable recovery. Although growth as such is a necessary condition for radically improved living conditions across the population, it is not necessarily the case that growth effortlessly translates into poverty alleviation. To see whether conditions are conducive to such a positive outcome, we now turn to the policy response to the crisis and its major components. In particular, we are interested in the types of policy that developed, the impact of those policies and the extent to which policy serves, or has the potential, to improve institutions that affect pro-poor growth.

\section{Policy response}

The immediate response to the crisis, unleashed by the abandoning of the fixed exchange rate of the Thai baht on 2 July 1997, focused on the recapitalization of the financial sector and debt rescheduling. Early on, a rescue package from the International Monetary Fund (IMF) was negotiated, a notable feature of which was that it was made conditional not only on the 
Table 6.2 Some socio-economic indicators for Thailand, 1996-2002

\begin{tabular}{|c|c|c|c|c|c|c|c|}
\hline & 1996 & 1997 & 1998 & 1999 & 2000 & 2001 & 2002 \\
\hline $\begin{array}{l}\text { GDP growth } \\
(\%, 1988 \text { prices })\end{array}$ & 5.9 & -1.4 & -10.5 & 4.4 & 4.6 & $1.9 \mathrm{P}$ & $5.3 \mathrm{P}$ \\
\hline $\begin{array}{l}\text { Agricultural } \\
\text { sector }\end{array}$ & 4.1 & -0.9 & -1.5 & 2.2 & 6.4 & $2.7 \mathrm{P}$ & $-0.5 \mathrm{P}$ \\
\hline $\begin{array}{l}\text { Non-agricultural } \\
\text { sector }\end{array}$ & 6.1 & -1.4 & -11.4 & 4.7 & 4.6 & $1.8 \mathrm{P}$ & $5.8 \mathrm{P}$ \\
\hline $\begin{array}{l}\text { Unemployment } \\
\text { (\% of labor } \\
\text { force) }\end{array}$ & 1.5 & 1.5 & 4.4 & 4.2 & 3.6 & 3.2 & 2.4 \\
\hline $\begin{array}{l}\text { Open } \\
\text { unemployment }\end{array}$ & 0.4 & 0.4 & 1.4 & 1.2 & 1.0 & 0.9 & \\
\hline $\begin{array}{l}\text { Passive } \\
\text { unemployment }\end{array}$ & 1.2 & 1.1 & 2.9 & 3.0 & 2.4 & 2.6 & \\
\hline $\begin{array}{l}\text { Seasonal inactive } \\
\text { (\% of labor } \\
\text { force) }\end{array}$ & 1.7 & 2.7 & 2.1 & 2.2 & 1.9 & 1.4 & 0.7 \\
\hline $\begin{array}{l}\text { Below national } \\
\text { poverty line }(\%)\end{array}$ & 11.4 & & 13.0 & 15.9 & 14.2 & 13.0 & 9.8 \\
\hline Gini coefficient & 0.515 & & 0.511 & 0.533 & 0.525 & 0.501 & \\
\hline
\end{tabular}

Source: Bank of Thailand: Key Economic Indicators; National Statistical Office: Core Economic Indicators of Thailand, Thailand Development Indicators 2003; Asian Development Bank: Key Indicators 2001, Key Indicators 2003, Thailand Country Strategy and Program Update (2002-2004). All online resources.

Note

$\mathrm{P}=$ preliminary.

austerity measures traditionally demanded, but also on substantial structural reform. About a year later, with a view to rectifying the weaknesses of the financial sector, the government launched a comprehensive financial restructuring package. This package, which was made public on 14 August 1998, set itself the aim of accelerating the consolidation of bank and finance companies, encouraging private investment to the banking system, making public funds available to recapitalize all remaining financial institutions, and developing a framework for the creation of private asset-management companies (MOF 1999).

The progress report of the Minister of Finance, released in January 1999, reported that the tax refunds due to exporters and corporations were being speeded up, and a temporary postponement of both the payment of corporate income tax and the remittance of state enterprises' profits was being introduced. Similarly, and in keeping with the original financial restructuring package, it was announced that the government was intent on removing tax disincentives to corporate debt restructuring. Within a few months the government also announced a major program to 


\section{Thai institutional adjustment and pro-poor growth}

stimulate domestic demand, notably through tax (value-added tax) cuts and other initiatives of the same type (e.g. a cap on select energy prices).

Economic reforms thus included several programs, many of which have already been or are at least in the process of being implemented. Changes made in monetary and fiscal policy, aiming at inflation abatement, maintaining aggregate demand and the re-establishment of a current account surplus, rank among those that can be classified as being part of the upper left hand panel in Figure 6.1 above. Measures taken to achieve financial sector reform and industrial restructuring fall into the upper right hand panel; these included, as well as a reform of bankruptcy and foreclosure laws, measures to strengthen corporate governance and to develop equity and other financial markets. The latter have since remained on the agenda as a major priority. In addition, the public sector was to be subjected to a thorough overhaul. Aiming to improve the efficiency of, and indeed, to minimize distortions created by public sector activities, privatization was pushed, as were measures to increase the accountability of public sector organizations and staff. Beyond reducing the costs of the civil service, this was also an attempt to reduce corrupt practices and increase the confidence in government. Each one of these measures of reform, except those that use public spending as a direct or indirect means to compensate for a temporary fall in aggregate demand, have implications for the institutional arrangements in their respective domains. As such, several of the above measures have the potential to benefit the poor along with the more affluent segments of the population; none of them, however, was specifically designed to redistribute resources in favor of the poor or to draw the poor into the mainstream of Thai economic and political life.

Social sector programs launched in the wake of the crisis similarly included steps taken with short-term poverty alleviation in mind, as well as measures intended for sustained medium and long-term impact (NESDB 1998, also MOF 1999). As an adequate social safety net did not exist prior to the crisis, the labor market and social welfare focused on immediate measures to support the unemployed, and extended social security coverage to include those who had been laid off. Other provisions aimed to achieve poverty alleviation in general, including in the informal and rural sectors. A 1999 survey of the ultra-poor, however, suggests that the most vulnerable were hardly reached at all (Medhi 2001).

Against this background it is particularly relevant to note that over the longer term, vulnerable groups of workers should specifically be targeted with support, and provincial authorities should be given a greater role as funds for poverty alleviation programs are to be made available to them. A Social Fund Office was established in September 1998 to disburse US\$120 million, originating from the World Bank, "as grants to people in the provinces who were suffering because of the recession". By mid-2002 most of the money had been used on 7,600 projects that affected 13 million 
people (Bangkok Post 17 June 2002). Above all, the improved competitiveness of labor was made a major objective, which in the Thai case inevitably implies a focus on education.

A first step in that direction has been an attempt to redress the immediate effects of the crisis (NESDB 1999). The Ministry of Education estimated that some 126,000 students dropped out of school; in parallel, the number of early school leavers also increased. A shift towards less costly education could be noticed, as enrollment in private schools decreased at a substantially higher rate than in public schools. Countermeasures included an increase in the budget allocation for student loans, a safeguarding of educational budgets, and an attempt to improve student-toteacher ratios. Over the longer term, the monitoring of quality in education and an improved regulatory framework were to be established.

Also, health measures to protect the poor were at the top of the agenda (NESDB 1998). Programs targeting women and children were to be given priority, while the provision of health services in rural areas was also identified as a major task for the authorities. Redeployment of staff from urban to rural areas and increased budgets for the Public Assistance and Voluntary Health Care schemes were also foreseen. Increased health sector competition and privatization of some health care facilities were also part of the long-term measures to be implemented; this was seen as a means of making health budgets sustainable over the longer term.

The combined effects of these programs are, generally speaking, much more difficult to pinpoint than the measures per se. The decentralization of the decision-making power and the responsibility for implementation appears as a major departure, but whether this implies any change in practice remains to be seen. It should be noted, however, that prior to the crisis, decision-making was decidedly centralized. This included not only issues related to budget expenditure and program implementation but also resource use at the local level, the latter of which often had to yield to perceived national priorities, including industrial or export interests. By way of an example, the environmental consequences of such priorities have been widely documented and the ruthless exploitation of natural resources has been a common theme in the criticisms levelled against the Thai economic policies by media, civil society organizations and academic circles alike. The fact, for example, that Thailand's National Environmental Quality Act of 1992 is comprehensive is of little consequence as long as it is not properly enforced.

Yet it is quite clear that some of the resources meant for the poor actually were used for their direct benefit. In rural areas, for instance, some of the money disbursed from the Miyazawa fund set up by the Japanese government in response to the crisis was used for communal projects such as road building and the maintenance of irrigation works (Molle and Thippawal 2000: 359), thereby generating temporary income for those employed on the projects. The extent to which this helped the poor is 


\section{Thai institutional adjustment and pro-poor growth}

unknown, although it is easy to appreciate that it served as a useful stopgap measure.

The effectiveness of the programs is thus difficult to gauge, but it must be underlined that many of the changes made in favor of those adversely affected by the consequences of the crisis were of a short-term nature. As stop-gap measures go, they can be questioned on grounds of sustainability; after all, they were not intended as permanent solutions. If anything, these measures, as well as the process of fiscal decentralization begun in the early 1990s, have contributed to the increasing budget deficits seen in Thailand in the wake of the crisis (Kanokpan 2002).

On the other hand, from the perspective of institutional adjustment, welfare programs, to the extent that they are being introduced on a more permanent basis, may have the beneficial effect of providing automatic stabilizers. These are likely to prove costly from a purely fiscal point of view, but may, on the other hand, cushion the effects of external or domestically generated macro-economic shocks. If so, this has the potential of reducing the vulnerability of the poor, both through the safety net itself and through the ability to maintain aggregate demand in face of adversity. However, there is a risk that such spending may run up against the provisions of the Budgetary Law, first promulgated in 1959. Stipulating that planned spending may not exceed planned expenditure by more than 20 percent, the law has served as an effective and automatic fiscal stabilizer (Warr 2000c: 131). Although it has subsequently been relaxed to allow for another 8 percent used for the repayment of the principal of public debt, it may, if honored and applied in tandem with the above welfare spending, imply a decisive shift of expenditure in favor of the less affluent segments of the Thai population.

The victory of Thaksin Shinawatra and his Thai Rak Thai Party at the polls in late 2000 has changed little in this respect. The policy declaration that incoming Prime Minister Thaksin delivered to the National Assembly on 26 February 2001 included the following pledges: (1) the "Village and Urban Revolving Fund", a central pillar of his election platform, where each village or local community was to receive one million baht (then about US $\$ 23,000)$; (2) the farmers' debt suspension program, where a three-year grace period was offered on loans taken by small farmers in order to allow them to weather the crisis; (3) the establishment of a "People's Bank", "to ensure better and improved access to banking facilities and resources for low income citizens to enhance their capacity to increasing their income from self employment and thus reduce their dependence [on] unorganized and punitive money market sources" (Thaksin 2001), as well as a similar organization for small and mediumsized enterprises; and (4) a universal health insurance, with a hospital visit costing no more than 30 baht and where equality of access was guaranteed.

The village fund, which takes the form of a revolving fund, has had the 
salutary effect of being available when banks withdrew their normal lending to farmers in the aftermath of the crisis. By providing credit, or allowing farmers the advantage of not having to turn to informal sector finance (i.e. moneylenders), the fund is indeed to be considered a positive intervention on behalf of the poor. Not everyone is impressed however, and Wipaphan Korkeatkachorn (2002) from the NGO Thai Action on Globalization noted that:

The One Million Baht Village Funds, for instance, are supposed to be a kind of transfer payment by the government to the disadvantaged sector of the population. Each village fund, however, is to provide loans to community members under the supervision of a village committee. One objective of the loans is to create jobs and income but a preliminary assessment of the loans reported that 80 percent of the US $\$ 158,000$ disbursed so far was used by villagers to pay back old debts. It seems likely that funds will create more non-performing loans in the rural sector.

It is also, however small, a part of the generally expansionary policies that Thaksin has been pursuing since assuming power, thereby contributing to the overall credit expansion and the attendant risk of increasing inflation and generating bubbles.

Similarly, the 30 baht hospital fee scheme can be seen as a cap that is low enough to be within the reach of the poor, indeed insuring them from fees that are well beyond their means. Under this scheme, every visit or treatment at one's home health care center is supposed to cost no more than 30 baht. On the other hand, a flat fee, as opposed to one based on income or paying capacity (which of course would be much more expensive to run) means a proportionally higher subsidy for those that can afford higher rates. This may matter less if gains are seen in absolute rather than relative terms, but to the extent that geographical distribution and accessibility of health services are regionally or locally differentiated, or to the extent that excess demand strains capacity, this scheme may still raise doubts on its pro-poor qualities. Similarly, to the extent that health providers depend on fees, as opposed to budgetary transfer (which in turn raises fiscal issues, in particular as low fees may create excess demand), the quality of services accessed are likely to reflect the low fees now charged.

While the village funds and the 30 baht cap both are fully operational, other promises have taken quite some time to reach the stage of implementation, in part because of the virtual standstill that dominated government work up to August 2001 (Bangkok Post 2002). But also, if the pledges made are eventually to be honored, the question of sustainability remains an issue of some consequence. Similarly, the ambition to by-pass the traditional centers of power in formulating, implementing and monitoring these programs has met a fair amount of skepticism. 


\section{Thai institutional adjustment and pro-poor growth}

\section{Institutions beyond the realm of economics: political reform}

To a considerable degree, the skepticism would seem to stem from the openly populist character of Thaksin's approach to politics, a criticism that could equally well be levelled at a number of governments pre-dating that dominated by the Thai Rak Thai party (Pasuk and Baker 2000). No matter the stand we take on this issue, it serves to highlight the insufficient attention typically devoted to political issues in the institutional analysis of the sort advanced by adherents of the New Institutional Economics. As a sympathetic critic of economics drawn from the ranks of political science has noted, while " "[p]olitical facts' thus lurk just beneath the surface of the new institutionalism", it fails to embed its analysis "within the study of politics" (Bates 1995: 42). In particular, Bates goes on to suggest, the issue of power is given short thrift, as are also the effects of party politics and the political system or setting as such. These are factors that not only are likely to have an impact on the structure and efficiency of economic institutions, but may also provide "explanations for the direction and magnitude of the departures from the status quo that economic institutions make possible" (Bates 1995: 44). In short, non-economic factors and institutions of both a systemic and contingent nature should be taken into account; as a heuristic device, the new institutionalism fails to do precisely that.

This remark is particularly apposite relative to Thailand, where the developments discussed above have run in parallel to constitutional reform (Prudhisan 1998, Funston 2000, Pasuk and Baker 2000). In fact, it is only a slight exaggeration to suggest that the shock of the crisis in 1997 paved the way for a successful completion of the process initiated already in response to the military coup in February 1991, and in particular following the pro-democracy demonstrations in May 1992, to make Thai politics more transparent and more directly answerable to the electorate. Institutional changes of this magnitude, especially since it was deliberately designed to undermine the entrenched, privileged positions of the few, could be expected to meet strong opposition from vested interests, and indeed it did. In October 1997 the "Peoples' Constitution" was promulgated and, in the words of the Chairman of the Constitutional Drafting Assembly, "returned power to the people" (Prudhisan 1998: 270). However, the very fact that a plethora of new courts, government agencies and ombudsmen are supported by the Constitution, many of which have a mission precisely to protect and promote the interests of the electorate, indeed all citizens, could possibly provide the means to circumvent or ignore the new provisions. The new Constitution might simply prove too ambitious to allow for transparency, clear priorities and consistency in implementation.

Although it is fair to say that the Constitution marks a major breakthrough in the realms of post-crisis institutional adjustment, it is not the 
only instance of the electorate or population at large moving its positions forward. Pasuk and Baker (2000: 115, 232) also note that technocrats saw their positions dented, while in general civil society increased its activism. As a result, corruption and nepotism came under increased attack. A National Counter Corruption Commission was set up in early 2000, and many politicians found themselves on the slippery slope, being ostracized for their selfserving actions. As the Constitution also contained provisions to stamp out vote buying, the time-honored practice of godfather politics was dealt a blow. In that sense the Constitution and the crisis returned a measure of power to middle class urbanites. As the Thai Rak Thai was elected to power, however, a partial reversal set in and, as Pasuk and Baker (2000: 235) remark, the results at the polls in 2000 "offered a mix of old and new". Indeed, casual observation suggests that this was something of a setback to the institutional adjustments induced by the crisis. In this context it is telling that it is only with the highly visible effects of the current government's expansionary economic policies that the middle class has warmed towards Prime Minister Thaksin - for however long as this may now last.

\section{Conclusion}

The overall conclusion of the above survey of measures taken by the Thai government in the wake of the Asian crisis of 1997 is one of limited institutional change. Other than the new constitution, which marks a major departure from the past, but which the current Prime Minister seems content to undermine to the best of his abilities, there are few indications that the institutional structure of Thailand has been made subject to anything but rather marginal adjustment. At the level of institutional arrangements, however, the impact of the reforms launched is both more far-reaching and more transparent. This is true both with respect to regulatory reform targeting the financial sector, and social sector programs. Whether these changes to the institutional arrangements will survive for long, or are profound and well designed enough to serve the purposes they were designed to meet, remains to be seen.

From the perspective of this chapter, the benchmark is not only sustainability, both as reforms and as seen from a macro-economic perspective, but if they indeed serve the purpose of pro-poor growth. Welfare systems, rudimentary as they are, are primarily intended to target the poor, and may therefore fall within this category, provided, of course, that they are implemented as intended. To the extent that they may also serve as automatic stabilizers for the economy in a downturn, these changes can be said to mark a major departure from the point of view of institutional arrangements. However, welfare benefits of this type are primarily of the re-distributive rather than efficiency-increasing variety.

As this analysis has operated at the national level, there is clearly scope for a regional and local approach to the research into the institutional 
arrangements as such and the effects thereof. Similarly, rather than focusing solely on those areas where reform has already taken place, research is needed on those spheres that were not directly affected by the crisis, but where reform is needed if the situation of the poor is to be improved. There is thus room for a more comprehensive analysis focusing on both formal and informal institutional constraints facing the poor in the wake of the Asian crisis. This is all the more true if, as the World Bank $(2000 / 2001,2002)$ argues, markets are important to the poor as markets can be used as a lever to mobilize resources that the poor command, thereby releasing their capabilities. If so, the obvious questions to answer include, how do institutions affect markets and what institutions are necessary for giving the poor access to markets?

Indeed, capabilities and freedoms, pace Sen (1999: 6), are important to the poor, but both are shaped by the various institutional constraints that may exist. Greeley (2000: 3) therefore suggests that "the development of local opportunities through relaxing of the institutional constraints that prevent the efficient functioning of markets" is a priority in formulating pro-poor policy. This should also be reflected in any study intent on extending the line of analysis pursued here.

All in all, the above raises important analytical and methodological questions, and may have important policy implications. For one, it may imply moving away from national representation based on averages, to representation based on cases, that is, the equivalent to the lower right panel in Figure 6.1 above. However, this is not sufficient. Also the micro-macro linkages have to be explored in a systematic fashion. This could take the form of a micro-based approach such as the livelihoods approach, and amending it to include an analysis of macro-level formal structures, such as legal provisions. Alternatively, or in parallel, it can be approached in the manner suggested by Lin and Nugent's (1995) term "institutional arrangement" as introduced above, the domain in question embracing both the macro and micro scales, be it within the sphere of macro-economic or micro-economic policies.

\section{Notes}

1 In the bibliography and annotations we follow the Thai usage for Thai names, i.e. authors are arranged by first name followed by the family name; citations are by the first name.

2 Organizations thus include political, economic, social and educational bodies.

3 See Eggertsson (1990) and Rutherford (1994) for assessments of the New Institutional Economics (NIE) school of thought, and Lin and Nugent (1995) for an overview of the NIE approach to development. On the latter, see also North (1995) and Toye (1995).

4 Kakwani uses an index, the pro-poor growth index, to find out. He also introduces the notion "immiserizing growth", which is growth that actually hurts the poor rather than being to their benefit. 


\section{References}

ADB (2001a) Asian Development Outlook 2001, Manila: Asian Development Bank.

- (2001b) Key Indicators 2001, Manila: Asian Development Bank. Online. Available at: <http://www.adb.org/Documents/Books/Key_Indicators/2001/ default.asp $>$ (accessed February 2002).

— (2001c) Thailand Country Strategy and Program Update (2002-2004), Manila: Asian Development Bank. Online. Available at: <http://www.adb.org/Documents/ CSPs/THA/2001/default.asp> (accessed February 2002).

- (2003) Key Indicators 2003, Manila: Asian Development Bank. Online. Available at: <http://www.adb.org/Documents/Books/Key_Indicators/2003/default.asp> (accessed December 2003).

Ahuja, V., Bidani, B., Ferreira, F.H.G. and Walton, M. (1997) Everyone's Miracle?, Washington, D.C.: The World Bank.

Bank of Thailand (various years) Key Economic Indicators. Online. Available at: $<$ http://www.bot.or.th/bothomepage/databank/EconData/KeyEcon/index_e. htm $>$ (accessed February 2002).

Bangkok Post (2002) "Year-end economic review 2001". Online. Available at: <http://bangkokpost.net/yearend2001/> (accessed February 2002).

Bates, R.H. (1995) "Social dilemmas and rational individuals: an assessment of the new institutionalism", in J. Harriss, J. Hunter and C.M. Lewis (eds) The New Institutional Economics and Third World Development, London: Routledge.

Booth, A. (1999) "The social impact of the Asian crisis: what do we know two years on?”, Asian-Pacific Economic Literature, 13(2): 16-29.

Deininger, K. and Squire, L. (1996a) "Deininger and Squire data set: a new data set measuring income inequality", Washington, D.C.: The World Bank. Online. Available at: <http://www.worldbank.org/research/growth/dddeisqu.htm> (accessed February 2002).

— (1996b) "A new data set measuring income inequality", World Bank Economic Review, 10(3): 565-591.

Deolalikar, A.B. (2002) Poverty, Growth, and Inequality in Thailand, ERD Working Paper Series, 8, Manila: Asian Development Bank.

Eggertsson, T. (1990) Economic Behavior and Institutions, New York: Cambridge University Press.

Funston, J. (2000) "Political reform in Thailand: real or imagined?", Asian Jourmal of Political Science, 8(2): 89-108.

Greeley, M. (2000) "Pro-poor growth: a review of three issues informing the current policy agenda", paper prepared for the export consultation conference on the OECD Poverty Reduction Guidelines, Callantsoog, the Netherlands, 13-14 September.

Hanks, L.M. (1972) Rice and Man: Agricultural Ecology in Southeast Asia, Honolulu: University of Hawaii Press.

Jones, G.W., Hull, T.H. and Ahlburg, D. (2000) "The social and demographic impact of the Southeast Asian crisis of 1997-99", Journal of Population Research, 17(1): 39-62.

Kakwani, N. (2001) "Pro-poor growth and policies", paper presented at the ADB 34th Annual Meeting (of the Board of Governors), 9-11 May, Honolulu, Hawaii.

Kakwani, N. and Medhi Krongkaew (2000) "Analysing poverty in Thailand", Journal of the Asia-Pacific Economy, 5(1-2): 141-160. 


\section{Thai institutional adjustment and pro-poor growth}

Kanokpan, Lao-Araya (2002) Effect of Decentralization Strategy on Macroeconomic Stability in Thailand, ERD Working Paper Series, 17, Manila: Asian Development Bank.

Kokko, A. (1999) "Thailand: emerging from the financial crisis?", manuscript, European Institute of Japanese Studies, Stockholm, September.

Lee, E. (1998) The Asian Financial Crisis: the Challenge for Social Policy, Geneva: International Labour Office.

Lin, J.Y. and Nugent, J.B. (1995) "Institutions and economic development", in J. Behrman and T.N. Srinivasan (eds) Handbook of Economic Development, 3A, Amsterdam: North-Holland Elsevier.

Medhi Krongkaew (2001) "Alienated life: socioeconomic characteristics of the ultra poor in Thailand", Journal of Asian and African Studies, 37(2): 128-146.

Medhi Krongkaew and Kakwani, N. (2003) "The growth-equity trade-off in modern economic development: the case of Thailand", Journal of Asian Economics, 14(5): 735-757.

MOF (1999) Thailand's Economic Reform: Progress Report, January 1999, Bangkok: Ministry of Finance. Online. Available at: <http://www.mof.go.th/ter199/ Thai_E_R.htm $>$ (accessed February 2002).

Molle, F. and Thippawal Srijantr (2000) "Le système agraire du delta du Chao Phraya: transformations et impact de la crise de 1997", Revue Tiers Monde, 41 (162): 343-363.

- (eds) (2003) Thailand's Rice Bowl: Perspectives on Agricultural and Social Change in the Chao Phraya Delta, Studies in Contemporary Thailand, 12, Bangkok: White Lotus Press.

NESDB (1998) "Thailand: social sector program policy matrix", SSSL Quarterly Newsletter, October, Bangkok: National Economic and Social Development Board.

_ (1999) "The real picture: school dropouts", SSSL Quarterly Newsletter, January, Bangkok: National Economic and Social Development Board.

NSO (various years) Core Economic Indicators of Thailand, Bangkok: National Statistical Office. Online. Available at: <http://www.nso.go.th/eng/indicators/eco/ economy.htm $>$ (accessed May 2002).

— (2003) Thailand Development Indicators 2003, Bangkok: National Statistical Office. Online. Available at: <http://www.nso.go.th/eng/THA_Indicat/THA_ Indicat2003.pdf $>$ (accessed September 2003).

North, D.C. (1990) Institutions, Institutional Change and Economic Performance, New York: Cambridge University Press.

(1995) "The new institutional economics and Third World development", in J. Harriss, J. Hunter and C.M. Lewis (eds) The New Institutional Economics and Third World Development, London: Routledge.

Pasuk Phongpaichit and Baker, C. (2000) Thailand's Crisis, Bangkok: Silkworm.

Prudhisan Jumbala (1998) "Thailand: constitutional reform amidst economic crisis", Southeast Asian Affairs 1998, Singapore: Institute of Southeast Asian Studies.

Quibria, M.G. (2002) Growth and Poverty: Lessons from the East Asian Miracle Revisited, ADB Institute Research Paper, 33, Manila: Asian Development Bank.

Rigg, J. (1988) "Land ownership and land tenure as measures of wealth and marginalization: evidence from northeast Thailand", Area, 20(4): 339-345.

— (1997) Southeast Asia: The Human Landscape of Modernization and Development, London: Routledge. 
(1998) "Tracking the poor: the making of wealth and poverty in Thailand (1982-1994)", International Journal of Social Economics, 25(6-8): 1128-1141.

Rodrik, D. (2000) "Institutions for high-quality growth: what they are and how to acquire them", Studies in Comparative International Development, 35(3): 3-31.

Rutherford, M. (1994) Institutions in Economics: The Old and the New Institutionalism, Cambridge: Cambridge University Press.

Sen, A. (1999) Development as Freedom, New York: Oxford University Press.

Sutham Nanthamongkolchai (2000) "Economic crisis impact on out-migrants from Bangkok", Warasan prachakonsat [Journal of Demography, Bangkok], 16(1): 59-69 [in Thai].

Thaksin Shinawatra (2001) "Policy of the Government of H.E. Prime Minister Thaksin Shinawatra delivered to the National Assembly on Monday, 26 February 2001", unofficial translation of the speech. Online. Available at: <http://www.thaigov.go.th/index_eng.htm>, under "Government policies" (accessed May 2002).

Toye, J. (1995) "The new institutional economics and its implications for development theory", in J. Harriss, J. Hunter and C.M. Lewis (eds) The New Institutional Economics and Third World Development, London: Routledge.

UNDP (1999) Human Development Report of Thailand 1999, Bangkok: United Nations Development Programme.

- (2001) Human Development Report 2001, New York: Oxford University Press.

Warr, P.G. (2000a) "Poverty incidence and economic growth in Southeast Asia", Journal of Asian Economics, 11(4): 431-441.

(2000b) "Is growth good for the poor? Thailand's boom and bust", International Journal of Social Economics, 27(7-10): 862-877.

— (2000c) "Myths about miracles: the case of Thailand", Journal of International Trade and Economic Development, 9(1): 115-134.

(2001) "Poverty, inequality, and economic growth: the case of Thailand", Journal of Asian and African Studies, 37(2): 113-127.

Wipaphan Korkeatkachorn (2002) "Public payment of private debt: the case of Thailand", report to International Peoples' Tribunal on Debt, II World Social Forum, Porto Alegre, Brazil, 1-2 February. Online. Available at: $<$ http://jubileesouth.org/tribunal/accusation_3/thailand.htm $>$ (accessed May 2002).

World Bank (1993) The East Asian Miracle: Economic Growth and Public Policy, New York: Oxford University Press. (2000/2001) World Bank Development Report 2000/2001: Attacking Poverty, New York: Oxford University Press.

(2002) World Bank Development Report 2002: Building Institutions for Markets, New York: Oxford University Press. 


\title{
7 Singapore's extra-ASEAN free trade agreements and their implications for ASEAN
}

\author{
Jose L. Tongzon
}

\section{Introduction}

Perhaps there are two major developments since the inception of the ASEAN Free Trade Area (AFTA) which have seriously tested the resolve of the ASEAN countries to bring this vision into reality: the recent economic crisis of 1997-1998 and Singapore's current foray into bilateral free trade agreements with non-ASEAN countries. ${ }^{1}$

The crisis of 1997-1998 has significantly stalled the economic progress experienced by ASEAN countries and set back the economic and social gains achieved in the past decades. The tragic terrorist attacks of 11 September 2001 have further exacerbated their economic problems and dampened the outlook for greater trade liberalization within the framework of the ASEAN Free Trade Area (AFTA). The recent initiatives by the Singapore government to forge bilateral free trade agreements (FTAs) with other countries outside ASEAN have also put further into question the future and effectiveness of ASEAN as a viable regional organization. The lack of a coordinated approach to the recent crisis and the lack of an immediate response to it have already put into question the effectiveness of ASEAN as a rallying point. Against this backdrop, this chapter will analyze whether the recent crisis has undermined the ASEAN countries' resolve to push ahead with the AFTA vision and whether, or to what extent, Singapore's recent initiatives to form bilateral free trade agreements with other countries outside the region will undermine ASEAN's future economic integration.

\section{The recent crisis and the future of AFTA}

The recent crisis has had negative implications for the future of ASEAN cooperation. Trade liberalization entails short-term adjustment costs resulting from a reallocation of human resources consistent with the principle of comparative advantage. During the transition period, workers that cannot retrain themselves with the appropriate skills may find themselves structurally unemployed. In countries such as Indonesia and Thailand, 
where unemployment and poverty have already risen from their pre-crisis levels due to the crisis, the costs of adjustments would become more severe and difficult. ${ }^{2}$ Corollary to this is the issue of division of gains and costs. The crisis has reinforced the fear that trade liberalization would only benefit the more developed and competitive member countries at the expense of surrendering one's national priorities and autonomy in policy setting. For example, despite its recent official agreement to accelerate AFTA's implementation, there were indications that Vietnam's pace of implementation of its trade liberalization commitments has further slowed during and after the crisis. Vietnam's economic development strategy for 1999 emphasized agricultural development with domestic market orientation and the importance of the state-owned enterprises (The Economist 14-20 November 1998). This indication was confirmed by Vietnamese officials' admission that the regional crisis has slowed down their economic reforms and forced them to be more inward-looking (Dow Jones International News 2 January 1999). Vietnam has not made any reference to their efforts to join the World Trade Organization (WTO) or their commitment to tariff reductions until recently with the signing of the historic US-Vietnam bilateral trade accord and the impending membership of China in the WTO.

The crisis, by causing greater debt servicing commitments and exchange rate instability, has also accentuated the major concern that countries with higher levels of protection, such as Indonesia, the Philippines, Thailand and Vietnam, will have to give up more in terms of tariff revenue loss, current account deterioration and job losses, than countries with lower levels of protection such as Singapore, Brunei and Malaysia. It has highlighted the question of mutuality of external trade and investment gains from AFTA. It has also intensified intra-ASEAN competition for non-ASEAN export markets and foreign investments, and could further raise this longstanding question of division of external gains among the ASEAN countries.

Despite these negative implications, the crisis seems to have strengthened the countries' political will and resolve for closer economic integration. The crisis has invoked the ASEAN sense of "shared destiny" and thus, reinforced their sense of determination to forge a greater level of economic cooperation; further, the contagion effect of the financial crisis has further demonstrated their high degree of economic inter-dependence, and therefore, highlighted the need for some policy coordination. It can be argued that the crisis has not at all derailed the implementation of their AFTA commitments; the progress made in meeting their AFTA commitment has been well on track. As Table 7.1 shows, in the area of the Common Effective Preferential Tariff (CEPT) commitments, during the crisis the ASEAN6 countries ${ }^{3}$ (with the exception of Thailand) had agreed to commit themselves to reduce their average tariff rates to below 5 percent by 2001 , ahead of the target year $2002 .{ }^{4}$ 
152 Singapore's extra-ASEAN free trade agreements

Table 7.1 ASEAN6 average CEPT tariff rates, in percent, 1997

\begin{tabular}{lrrrrrrrr}
\hline Country & 1996 & 1997 & 1998 & 1999 & 2000 & 2001 & 2002 & 2003 \\
\hline Brunei & 1.58 & 1.58 & 1.21 & 1.16 & 0.90 & 0.87 & 0.87 & 0.84 \\
Indonesia & 9.05 & 8.53 & 7.05 & 5.82 & 4.92 & 4.61 & 4.20 & 3.72 \\
Malaysia & 4.62 & 4.04 & 3.41 & 3.01 & 2.58 & 2.41 & 2.27 & 1.97 \\
Philippines & 9.22 & 9.20 & 7.71 & 6.79 & 5.45 & 4.96 & 4.68 & 3.72 \\
Singapore & 0.00 & 0.00 & 0.00 & 0.00 & 0.00 & 0.00 & 0.00 & 0.00 \\
Thailand & 14.41 & 13.10 & 10.46 & 9.65 & 7.29 & 7.27 & 5.93 & 4.63 \\
Total ASEAN6 & 6.68 & 6.08 & 4.97 & 4.41 & 3.52 & 3.35 & 2.93 & 2.48 \\
\hline
\end{tabular}

Source: ASEAN Secretariat (1997).

Note

All figures are mutually agreed tariff commitments, except for 1996 and 1997, which are actual CEPT tariff rates.

Moreover, they are now more committed to realize the vision of free trade amongst themselves by signing an agreement at the September 1999 ASEAN Economic Ministers Meeting in Singapore to adopt a target of zero tariffs to be achieved by 2015 for the ASEAN6, and by 2018 for the ASEAN4. ${ }^{5}$

Apart from the deepening of tariff cuts, they have also resolved to further expand the commodity coverage of AFTA. After deciding to include the politically sensitive unprocessed agricultural products (UAPs) into the CEPT scheme, to be phased into the Inclusion List in five equal instalments, significant progress has been made since 1996. Out of a total of 1,995 UAP tariff lines, 1,358 tariff lines were phased into the Inclusion List in 1996 and another 402 tariff lines were given Temporary Exclusion List (TEL) status to be phased into the CEPT scheme in seven equal instalments between 1997 and 2003.

Due to ASEAN efforts to review and shorten the General Exclusion List (GEL), some 230 tariff lines (29 percent) have been transferred out of the GEL into the Inclusion List at the 13th AFTA Council meeting in September 1999. Consequently, the Inclusion List now covers over 98 percent of all tariff lines for the ASEAN6 countries, as shown in Table 7.2. Although the Inclusion Lists for the transitional member economies are not as large, they are still significant. Vietnam's Inclusion List has also expanded in absolute and proportional terms since its first submission of a CEPT product list in 1996 (see Table 7.3).

Some progress has also been made with regards to the inclusion of sensitive products. Some UAPs are classified as "sensitive" or "highly sensitive" which called for a special arrangement. At the 31st ASEAN Economic Ministers Meeting in October 1999, the ministers endorsed a Protocol on the Special Arrangement for Sensitive and Highly Sensitive Products which set out the mechanism for the integration of sensitive products into the CEPT 
Table 7.2 ASEAN6 CEPT product list, as of 1 January 2002

\begin{tabular}{|c|c|c|c|c|c|}
\hline Country & $\begin{array}{l}\text { Inclusion } \\
\text { list }\end{array}$ & $\begin{array}{l}\text { Temporary } \\
\text { exclusion } \\
\text { list }\end{array}$ & $\begin{array}{l}\text { General } \\
\text { exclusion } \\
\text { list }\end{array}$ & $\begin{array}{l}\text { Sensitive } \\
\text { list }\end{array}$ & Total \\
\hline Brunei & $\begin{array}{l}6,276 \\
(96.67)\end{array}$ & & $\begin{array}{l}202 \\
(3.11)\end{array}$ & $\begin{array}{l}14 \\
(0.22)\end{array}$ & 6,492 \\
\hline Indonesia & $\begin{array}{l}7,213 \\
(99.01)\end{array}$ & & $\begin{array}{l}68 \\
(0.93)\end{array}$ & $\begin{array}{l}4 \\
(0.05)\end{array}$ & 7,285 \\
\hline Malaysia & $\begin{array}{l}10,039 \\
(96.59)\end{array}$ & $\begin{array}{l}218 \\
(2.1)\end{array}$ & $\begin{array}{l}53 \\
(0.51)\end{array}$ & $\begin{array}{l}83 \\
(0.8)\end{array}$ & 10,393 \\
\hline Philippines & $\begin{array}{l}5,571 \\
(98.79)\end{array}$ & $\begin{array}{l}6 \\
(0.11)\end{array}$ & $\begin{array}{l}16 \\
(0.28)\end{array}$ & $\begin{array}{l}46 \\
(0.82)\end{array}$ & 5,639 \\
\hline Singapore & $\begin{array}{l}5,859 \\
(100.0)\end{array}$ & & & 5,859 & 5,859 \\
\hline Thailand & $\begin{array}{l}9,104 \\
(99.92)\end{array}$ & & & $\begin{array}{l}7 \\
(0.08)\end{array}$ & 9,111 \\
\hline Total ASEAN6 & $\begin{array}{l}44,062 \\
(98.4)\end{array}$ & $\begin{array}{l}224 \\
(0.50)\end{array}$ & $\begin{array}{l}339 \\
(0.76)\end{array}$ & $\begin{array}{l}154 \\
(0.34)\end{array}$ & 44,779 \\
\hline
\end{tabular}

Source: ASEAN Secretariat (2002).

Note

The figures in brackets are percentage shares for the various categories.

Table 7.3 ASEAN4 CEPT product list, as of 1 January 2002

\begin{tabular}{|c|c|c|c|c|c|c|c|c|c|c|}
\hline \multirow[t]{2}{*}{ Country } & \multicolumn{2}{|c|}{$\begin{array}{l}\text { Inclusion } \\
\text { list }\end{array}$} & \multicolumn{2}{|c|}{$\begin{array}{l}\text { Temporary } \\
\text { exclusion } \\
\text { list }\end{array}$} & \multicolumn{2}{|l|}{$\begin{array}{l}\text { General } \\
\text { exclusion } \\
\text { list }\end{array}$} & \multicolumn{2}{|l|}{$\begin{array}{l}\text { Sensitive } \\
\text { list }\end{array}$} & \multicolumn{2}{|c|}{ Total } \\
\hline & 1996 & 2002 & 1996 & 2002 & 1996 & 2002 & 1996 & 2002 & 1996 & 2002 \\
\hline Cambodia & & $\begin{array}{l}3,115 \\
(45.66)\end{array}$ & & $\begin{array}{l}3,523 \\
(51.64)\end{array}$ & & $\begin{array}{l}134 \\
(1.96)\end{array}$ & & $\begin{array}{l}50 \\
(0.74)\end{array}$ & & 6,822 \\
\hline Laos & & $\begin{array}{l}2,098 \\
(59.08)\end{array}$ & & $\begin{array}{l}1,291 \\
(36.36)\end{array}$ & & $\begin{array}{l}74 \\
(2.08)\end{array}$ & & $\begin{array}{l}88 \\
(2.48)\end{array}$ & & 3,551 \\
\hline Myanmar & & $\begin{array}{l}3,580 \\
(65.42)\end{array}$ & & $\begin{array}{l}1,823 \\
(33.32)\end{array}$ & & $\begin{array}{l}48 \\
(0.88)\end{array}$ & & $\begin{array}{l}21 \\
(0.38)\end{array}$ & & 5,472 \\
\hline Vietnam & $\begin{array}{l}857 \\
(38.64)\end{array}$ & $\begin{array}{l}5,505 \\
(86.14)\end{array}$ & $\begin{array}{l}1,189 \\
(53.61)\end{array}$ & $\begin{array}{l}696 \\
(10.89)\end{array}$ & $\begin{array}{l}146 \\
(2.28)\end{array}$ & $\begin{array}{l}139 \\
(2.18)\end{array}$ & $\begin{array}{l}26 \\
(5.47)\end{array}$ & $\begin{array}{l}51 \\
(0.79)\end{array}$ & 2,218 & 6,391 \\
\hline Total & & $\begin{array}{l}14,298 \\
(64.30)\end{array}$ & & $\begin{array}{l}7,333 \\
(32.98)\end{array}$ & & $\begin{array}{l}395 \\
(1.78)\end{array}$ & & $\begin{array}{l}210 \\
(0.94)\end{array}$ & & 22,236 \\
\hline
\end{tabular}

Source: ASEAN Secretariat (1997, 2002).

Notes

Vietnam joined ASEAN in 1995, Laos and Myanmar in 1997 and Cambodia in 1999.

Figures in brackets are percentages. 


\section{Singapore's extra-ASEAN free trade agreements}

scheme by 2010 , with $0-5$ percent tariff rates subject to no quantitative restrictions (QRs) or non-tariff barriers (NTBs). Rice was, however, exempted from this mechanism by being allowed to have an end-tariff of over 5 percent, but with no QRs or NTBs. Rice has always been a very difficult commodity to liberalize due to the fact that each ASEAN member country, particularly Malaysia, Indonesia and the Philippines, wants to develop self-sufficiency in rice as a matter of economic and political security.

In most cases, unilateral tariff reductions have been undertaken with the assumption that even without reciprocity, trade liberalization would be in their long-term economic interests. Moreover, the private industry sectors, having realized the economic benefits of trade liberalization in a sub-regional framework, have been pressuring their respective governments to expedite the process of trade liberalization under AFTA.

The beginning of 2002 marked the target year for the final implementation of the ASEAN6 countries' tariff reduction commitment to between 0 and 5 percent. But, by 1 January 2002, based on their respective Inclusion Lists (IL) as shown in Table 7.2, the following number of items did not have their duties reduced to $0-5$ percent: 16 items $(0.25$ percent $)$ of Brunei's 2002 IL; 66 items (0.92 percent) of Indonesia's 2002 IL; 922 items (9.2 percent) of Malaysia's $2002 \mathrm{IL} ; 199$ items (3.57 percent) of the Philippines' 2002 IL; and 472 items (5.18 percent) of Thailand's $2002 \mathrm{IL}$ (ASEAN Secretariat, 2002). Please refer to Table 7.4 for more details.

Most of these temporarily excluded products are in the motor vehicles and parts categories, which were exempted from the 2002 deadline and given an extra-grace period of four years before their inclusion, mainly due to the strong objection from Malaysia, and in the plastic and chemicals categories as suggested by Indonesia. As pointed out by the ASEAN Secretariat, the ASEAN6 member countries have always made it clear that their objective for 2002 was to reduce the duties for the products in the Inclusion List to $0-5$ percent with some flexibility allowed. If this is the case, then one can say that the ASEAN6 countries have successfully realized the first phase of regional economic integration.

The remaining tasks in the second phase of the regional economic integration, however, are more difficult to carry out. First, the non-tariff barriers that significantly exist in the region still need to be eliminated or harmonized. Second, there is a need to improve the institutional structure of ASEAN to make it more effective in rallying the individual members towards a coordinated stance or common action in dealing with future crises and in the implementation and enforcement of decisions. The longstanding principles of non-interference in the domestic affairs of other members, and of consensus, have done well for the survival and development of ASEAN in the past, but have also been partly responsible for the slow progress of the economic integration. The second phase is certainly more challenging than the first phase of trade liberalization. Surcharges, 
Table 7.4 Implementation of tariff reduction commitments in ASEAN, as of 1 January 2002

\begin{tabular}{|c|c|c|c|c|c|c|}
\hline \multirow[b]{2}{*}{ Countries } & \multicolumn{2}{|c|}{ Number of tariff items } & \multicolumn{4}{|c|}{ Percentages } \\
\hline & $0-5 \%$ & $>5 \%$ & Total & $0-5 \%$ & $>5 \%$ & Total \\
\hline Brunei & 6,260 & 16 & 6,276 & 99.75 & 0.25 & 100 \\
\hline Indonesia & 7,147 & 66 & 7,213 & 99.08 & 0.92 & 100 \\
\hline Malaysia & 9,117 & 922 & 10,039 & 90.82 & 9.18 & 100 \\
\hline Philippines & 5,372 & 199 & 5,571 & 96.43 & 3.57 & 100 \\
\hline Singapore & 5,859 & & 5,859 & 100 & 0 & 100 \\
\hline Thailand & 8,632 & 472 & 9,104 & 94.82 & 5.18 & 100 \\
\hline Total ASEAN6 & 42,337 & 1,685 & 44,022 & 96.17 & 3.83 & 100 \\
\hline Cambodia & 238 & 2,877 & 3115 & 7.64 & 92.36 & 100 \\
\hline Lao PDR & 1,297 & 801 & 2,098 & 61.82 & 38.18 & 100 \\
\hline Myanmar & 2,848 & 732 & 3,580 & 79.55 & 20.45 & 100 \\
\hline Vietnam & 3,566 & 1,939 & 5,505 & 64.78 & 35.22 & 100 \\
\hline Total ASEAN4 & 7,949 & 6,349 & 14,298 & 55.6 & 44.4 & 100 \\
\hline Total ASEAN10 & 50,286 & 8,034 & 58,360 & 86.17 & 13.83 & 100 \\
\hline
\end{tabular}

Source: ASEAN Secretariat (2002).

technical standards and customs procedures are the three most commonly used instruments of protection adopted by the ASEAN countries. Further, although there has been more differentiation in the commodities produced in these economies, thus creating more scope for greater complementarity between the countries, there are still significant differences between them, which could slow down the progress in economic integration. The crisis and the expansion of ASEAN to include the transitional economies of the region have certainly widened the level of diversity within ASEAN in terms of economic development, economic priorities and readiness towards economic liberalization.

\section{Singapore's extra-ASEAN free trade agreements and their implications for ASEAN}

Singapore is an active member of ASEAN and a signatory of the ASEAN Free Trade Area (AFTA) agreement whose ultimate objective is to create a regional market among the countries of Southeast Asia where goods and services can move freely across borders unhampered by any trade barriers. This vision will be realized in stages, and the year 2002 was the target year for the reduction of tariffs across the economies of the ASEAN6 to between 0 and 5 percent with the complete elimination of all trade barriers by 2015 . 


\section{Singapore's extra-ASEAN free trade agreements}

As a small open economy with high dependence on foreign trade, Singapore has been an active proponent for this regional economic initiative and considered it as one of the pillars of its foreign trade policy. However, right after the recent Asian economic crisis, there has been a concerted effort by Singapore to establish free trade agreements (FTAs) with other countries - a deviation from its previous behavior. After the formation of the New Zealand-Singapore FTA, Singapore signed a free trade agreement with Japan and made substantial progress in its negotiations with the United States and Australia.

This section will attempt to provide an overview of the reasons behind Singapore's recent enthusiasm to forge FTAs with other countries outside the region, and to evaluate the economic implications for ASEAN and the validity of the concerns raised by the other ASEAN countries over Singapore's FTA initiatives. The economic evaluation will be based on a case study of the recently signed Japan-Singapore FTA. ${ }^{6}$

\section{Why bilateral free trade agreements for Singapore?}

Singapore's high dependence on trade has been widely documented. In fact, the country has one of the highest trade-to-GDP ratios in the world. Therefore, it is in the nation's interests to ensure that trade flows around the world will be as uninterrupted as possible. Hence, Singapore, described as "a vocal champion of global free trade", has been one of the avid supporters of the multilateral trade negotiations and non-discriminatory trading environment under the auspices of the WTO. At the same time, however, Singapore is also an active member of regional groupings, such as the ASEAN Free Trade Area (AFTA) and the Asia Pacific Economic Cooperation (APEC), which aim at achieving regional free trade. Although Singapore appears to support two seemingly irreconciliable approaches to trade policy by endorsing both multilateral trade negotiations and regional groupings, the country's recent initiatives at forging free trade agreements with countries outside the region could be interpreted as part of the overall trend towards regionalism.

One factor behind this trend relates to the growing doubt about the ability of the WTO to advance trade liberalization under the multilateral system, particularly after the failure of the WTO meeting in Seattle. Apart from the difficulty of reconciling the diverse and often conflicting interests of its 139 members, the WTO trade negotiations have also been complicated by the emergence of controversial issues like human rights, and environmental degradation. Moreover, there appears to be a lack of leadership in multilateral trade negotiations. With the US no longer a hegemonic power in international trade, and given the absence of a dominant force directing negotiations, reaching a consensus in the organization seems to be an insurmountable task. Singapore, like other proponents of FTAs, believes that reducing the number of negotiators can 
lead to a corresponding decrease in the number and complexity of issues involved, giving free trade negotiations a better chance of success. Building on this likely liberalization of trade within FTAs, multilateral free trade can then be subsequently achieved. This is because domestic confidence regarding market liberalization will be built up through FTAs, therefore preparing the way for the multilateral stage (Singapore Ministry of Trade and Industry 2004). FTAs are therefore seen as the building blocks to eventual global free trade. This positive view of FTAs has been endorsed by the WTO, which stated in 1996 at its Singapore Ministerial Conference that such agreements are complementary to the multilateral trading system.

A second factor is that, given the trend towards regionalism among developed countries, the formation of FTAs is considered as a way to maintain Singapore's bargaining position vis-à-vis other regional groupings so that it is not left out of the major export markets. Indeed, Singapore's Trade and Industry Minister George Yeo expressed concerns that the other nations' FTAs could deal Singapore out of the table. It was under these circumstances that Singapore decided to "play the system" (Low 2000) and embarked on a quest for FTAs with its "strategic trading partners". In doing so, Singapore will be able to maintain a foothold in the major regional groupings that have been formed and hence remain engaged in the global trading scene.

Apart from these factors, there could be other specific issues that have prompted Singapore's move to expedite the negotiations for bilateral free trade agreements with non-ASEAN countries. First, Singapore might have observed that AFTA has not been progressing as fast as expected. The growing emphasis on inward-looking policies in some ASEAN countries after the 1997-1998 Asian economic crisis and Malaysia's deferment of its commitment to fully liberalize its automotive industry were seen as signs of backsliding on AFTA commitments. The anticipated slow progress in economic integration and the need for Singapore to position itself in the changing global trading environment have caused Singapore to form free trade agreements with other countries outside the region. As Prime Minister Goh Chok Tong put it, "Those who can run faster should run faster. They shouldn't be restrained by those who don't want to run at all" (Asiaweek 8 December 2000). Second, Singapore could be planning to reduce its dependence on the regional economies after its bitter experience with the recent regional economic crisis. By forging closer economic ties with its major trading partners outside the region, Singapore could ensure its economic resilience and security. Seen in this context, the bilateral pact with Japan provides a launching pad for Singapore to penetrate the East Asian economies, considering that Japan is also planning to form bilateral trading arrangements with Korea and China. Similarly, Singapore's approach to the European Free Trade Association (EFTA) countries is done with the prospects of the larger but highly 
protective European market, while the Chilean and US initiatives are to link Singapore with the greater Latin and North American markets. ${ }^{7}$

\section{Implications for ASEAN}

Singapore's pursuit of extra-ASEAN FTAs has been criticized by some fellow ASEAN members. Apart from the criticism that the other ASEAN countries were not adequately consulted by Singapore as to the objectives and modalities of the proposed pacts and how they would fit in within the AFTA process, these arrangements are seen by some as undermining ASEAN as a preferential trading arrangement. Specifically, it is claimed that these free trade arrangements could be providing Singapore's FTA partners with a backdoor entry into the ASEAN Free Trade Area. Are there any grounds for these criticisms?

\section{Benefits for ASEAN?}

Before addressing the major concerns raised by the other ASEAN countries, there is a need to explore whether these countries can benefit directly or indirectly from these extra-ASEAN FTAs. The following analysis will focus on the Japan-Singapore Free Trade Agreement (JSFTA), which is probably the most promising and important agreement for Singapore. ${ }^{8}$ Although the proposed US-Singapore agreement is also important, it has not been in operation as long as the one with Japan.

The Japan-Singapore Free Trade Agreement Joint Study Group, which submitted a recommendation for the scope of the negotiations in 2000, has explicitly stated the various measures for Singapore and Japan to cooperate on that could have a direct impact on other ASEAN countries. For instance, if the proposal to build the Japan Business Center in Singapore is realized, the ASEAN countries will benefit from the joint ventures formed by Japanese and Singaporean SMEs. One of the stated aims of this center is to enable these joint ventures to collaborate in exploring business opportunities in the ASEAN countries.

It was also suggested that the regulatory and policy framework that Singapore and Japan will set up to bring together their infocommunications and e-commerce industries could be extended to include the e-ASEAN ${ }^{9}$ initiative. The realization of such a plan will see the entire ASEAN market linked to Japan in the electronic realm. Such a situation is likely to boost the attractiveness of ASEAN countries as an investment location, since firms based in the relatively low-cost ASEAN countries will have electronic access to the vast Japanese market. However, doubts have been raised about the feasibility of transforming the e-ASEAN plan into reality, due to the diverse stages of development that the various ASEAN countries are in. Will there be political will to see through this long-drawn project, which entails the harmonizing of the more sophisticated Singapore One 
and the Malaysian Multimedia Super Corridor projects, with the barelyexistent telecommunications network in Myanmar and Cambodia? Until such a project is completed, the proposed electronic link-up to Japan under the JSFTA is likely to remain a pipedream without concrete benefits for ASEAN.

Other specific measures include the provision of assistance for ASEAN members to develop their human resources. However, there have been earlier initiatives that did the same even before the JSFTA was mooted. In 1997 , the two countries signed an agreement to combine their resources to help developing countries through the "Japan-Singapore Partnership Program for the 21st Century" (JICA 2004). As such, any further attempts to assist the ASEAN countries in the area of human resource development could be provided under the auspices of this earlier program, thus rendering the efforts under the JSFTA to be largely duplicative and providing little additional benefits to the ASEAN countries.

Another recommendation by the Joint Study Group is that the Japan National Tourist Organisation (JNTO) and Singapore Tourism Board (STB) cooperate in developing tourism in the region. Such an initiative can be beneficial for many of the ASEAN members, who count tourism as one of their important sources of revenue. However, there are also existing efforts to do so through the ASEAN Promotion Center on Trade, Investment and Tourism.

By now, we should recognize the fact that Japan has maintained a strong relationship with ASEAN since the formalization of the relationship in 1977. Despite fears that Japan may be losing interest in ASEAN as it turns its attention to its Northeast Asian neighbors, we see that Japan still maintains a variety of economic, social and political links to the ASEAN countries through platforms like the ASEAN Regional Forum (ARF), Japan-ASEAN Program for Comprehensive Human Resources Development, ASEAN-Japan Forum, Japan-ASEAN exchange project, etc. The ASEAN Promotion Centre on Trade, Investment and Tourism, which was established by Japan in 1981, also continues to realize its main aims of promoting exports from ASEAN to Japan, accelerating the inflow of investment from Japan to ASEAN, and to encourage Japanese tourists to visit ASEAN countries.

In view of the above, we could argue that if Singapore was keen on cooperating with Japan in order to provide various forms of assistance to its ASEAN counterparts, it has numerous opportunities to do so under the extant schemes. Hence, it is unlikely that the JSFTA will have much to offer to ASEAN in terms of providing a new link through which Japan can explicitly channel various forms of assistance.

Perhaps in recognition of the fact that the JSFTA may offer few extra benefits in terms of providing ASEAN with new avenues for assistance from Japan, Singapore's leaders have preferred to emphasize the "catalytic" effect of the JSFTA on ASEAN. Although the JSFTA may not offer 
well-defined marginal economic benefits for ASEAN countries, there can be some spillover effects from the trade pact between Singapore and Japan. As the WTO Secretary-General, Supachai Panitchpakdi, noted, "Whatever Singapore does, it can generate spinoffs for ASEAN" (The Business Times 21 February 2001). Indeed, Singapore's Prime Minister Goh argued that Singapore's trade pacts with non-ASEAN countries could "help investors outside the region to look at the potentials of ASEAN as a whole" (Agence France Presse 26 January 2001). This is important, as foreign investors' confidence in this region has been badly shaken by the Asian financial crisis and the political unrest in several ASEAN countries after the crisis. Japan's decision to forge a comprehensive agreement with an ASEAN country can thus be viewed as an endorsement of the long-term prospects of the region, and hence pave the way for the international community to regain its confidence and interest in this region.

Next, we should recognize that Singapore does not have unlimited capacity to absorb all of the investment that can result from the JSFTA. It is likely that the efforts to attract Japanese investors to Singapore through the various investment missions, and business seminars, can result in significant spillovers to the ASEAN countries. As mentioned earlier, Japanese investors in Singapore have tended to engage in "third country investment" projects, using Singapore as a springboard for further investment in neighboring countries. Hence, successful attempts to attract Japanese investors to Singapore through the schemes mooted under the JSFTA can provide a valuable stepping stone towards further Japanese investment in the region as a whole. It has to be qualified that the abovementioned spillover effects can only be realized if conditions in ASEAN countries are favorable for investors. Thus, the onus is still on the ASEAN member countries to prove their viability and reliability as an investment location.

There have also been suggestions that Singapore's moves to conclude free-trade agreements can set the pace for other ASEAN countries to do the same in future. At present, many ASEAN countries are still dogged by the domestic problems that stemmed largely from the financial crisis in 1997-1998. The preoccupation with the resolution of these internal issues has caused the countries to devote too little attention and resources to react to the international trend of regionalization. Singapore is therefore positioning itself as a convenient example that these ASEAN countries can follow when they are ready to forge FTAs after overcoming their domestic problems. ${ }^{10}$ However, fundamental differences between Singapore and its neighbors suggest that its experience in the JSFTA may be of limited use to its neighbors.

First of all, as Schott (1991) points out, an essential ingredient of a successful FTA is that the members have similar laws and regulations governing trade flows. Indeed, the JSFTA negotiations have been largely smooth-going so far, as both countries see eye to eye on many issues, like the liberalizing of trade flows in many goods and services. In contrast, 
many sectors in the other ASEAN countries, like the automotive and financial industries, have yet to be fully liberalized. Hence, as long as such protectionist inclinations persist in the ASEAN countries, it would be difficult for them to accept Singapore's guidelines for use in any of their future FTAs with Japan.

Next, Singapore is unlikely to face much domestic opposition to the FTA since it is at a relatively similar stage of development as Japan. This is because whatever trade that is created between Singapore and Japan as a result of the JSFTA is likely to be intra-industry rather than inter-industry. As such, the FTA will cause minimal adjustments in trade flows, and thus insignificant redistribution of income and employment (Schott 1991). An FTA between Japan and the other less developed ASEAN countries, on the other hand, may cause more domestic disruptions as the domestic capitalintensive industries may find themselves edged out by the more efficient Japanese producers. Therefore, it might be less useful for ASEAN countries to refer to Singapore's experience in dealing with such FTA-related issues.

\section{Concerns of ASEAN members}

Although these initiatives could be of some indirect benefit for ASEAN, these bilateral trade pacts have been riddled with criticism, coming primarily from the former president of Indonesia Abdurrahman Wahid and the former prime minister of Malaysia Mahathir Mohamad. Both have shown no hesitation in attacking the actions of Singapore. Former president Wahid saw the Singaporeans as only looking after themselves in search for more profits. Former prime minister Mahathir expressed concerns that these non-ASEAN bilateral trading arrangements could undermine ASEAN solidarity. Singapore's formation of bilateral free trade agreements with New Zealand, Japan, Australia and the US and the pending ones with Korea and India, have been perceived as forsaking ASEAN interests for national interests. But the key contention is that Singapore could be providing its potential FTA partners with a backdoor entry into AFTA. Critics have alleged that these FTA partners will be able to gain tariff-free access into ASEAN markets through Singapore, without providing reciprocal access to the ASEAN countries (Asiaweek 8 December 2000).

A closer analysis of the situation, however, reveals that there is little truth in this argument. The fundamental reason that refutes the "backdoor" claim lies in the rules of origin. As defined by the WTO, these are essentially rules that "define where a product was made". Since members of an FTA often maintain their own tariffs for non-members, there is a tendency for countries outside the area to circumvent the higher tariffs in a member country by exporting to the lowest-tariff member country, and then re-exporting to the higher tariff ones, at the preferential tariff rate established under the FTA. Rules of origin will rein in such behavior since 


\section{Singapore's extra-ASEAN free trade agreements}

products must fulfill the specified criteria before being able to enjoy the preferential tariff treatment granted by the FTA. ${ }^{11}$ In the case of AFTA, member countries' exports to one another will only be eligible for the Common Effective Preferential Tariff Scheme (CEPT), ${ }^{12}$ if these goods have a local content of 40 percent, i.e. 40 percent of the value-added to the product must originate from one or more ASEAN countries. Such requirements can inflate the costs for any foreign producer who attempts to seek a backdoor entry into AFTA. This is because they will need to relocate the entire manufacturing plant, or at least split up the production process between the home country and the low-tariff AFTA country, in order to fulfill the 40 percent local content requirements. The costs involved in doing so are likely to offset any savings in tariff payments that result from the use of the "backdoor".

Approximately 96 percent of exports to Singapore are already tariffexempt. This implies that the tariff differential between these exports to Singapore and those to other ASEAN countries is already at a maximum; at a tariff rate of 0 percent there is no further room for tariff reductions in Singapore for these imports. In view of these tariff differentials, Singapore already presents the opportunity for firms to gain a backdoor entry into AFTA. Thus, even without a bilateral pact with Singapore, foreign exporters who are keen on seeking a backdoor entry to any other ASEAN country would have already based at least 40 percent of their production process in Singapore to take advantage of the tariff differentials. It is probably safe to assume that the foreign exporters who have not done so have found the opportunity cost to be too great compared to any tariff payments that can be saved as a result.

It is unlikely that a bilateral trade pact with Singapore will provide much cause for these foreign exporters to review their location choice decisions. The reason is that under Singapore's current FTAs, the only preferential tariff treatment granted to its partners is the elimination of customs duty on the dutiable goods. This means that only goods in four product categories ${ }^{13}$ will enjoy tariff concessions. If Singapore maintains such a criterion for its future FTAs, there will be hardly any further increase in the tariff differentials between any exports from its FTA partners to Singapore and those to the other AFTA members, such that it will not be worthwhile for exporters from the partner countries to try to use Singapore as a "backdoor" into the AFTA economies.

\section{The automotive industry - an example}

The automotive industry is a prominent example of a protected industry in the ASEAN countries. Under the AFTA CEPT scheme, ASEAN countries have agreed to reduce the tariffs on automotive imports from AFTA members, to a $0-5$ percent range by 2002 . However, these countries still maintain high tariffs on identical imports from non-AFTA countries. 
Thus, there could be fears that Japanese automotive firms may make use of this scheme to penetrate the ASEAN markets through Singapore, after the JSFTA comes into effect. Specifically, in order to fulfill AFTA's rules of origin, Japan may export $60 \%$-completed motor vehicles into Singapore for completion, or even start a complete manufacturing plant from scratch in Singapore. The final product will then be exported into ASEAN countries at the stipulated preferential rate. Several factors, however, will ensure that such a scenario will probably never materialize.

First, major Japanese automotive firms like Mitsubishi Motors, Nissan and Toyota have already established automotive manufacturing plants in ASEAN countries like Thailand and the Philippines. These were facilitated by the ASEAN Industrial Complementation (AIC) and Brand-to-Brand (BBC) schemes, which provided reduced tariffs on automotive parts traded within the region (Yoshino 2000). These schemes have, therefore, provided non-AFTA members with a somewhat de facto backdoor entry into AFTA. By basing their production operations in ASEAN countries, Japanese firms are able to offset part of the high tariff costs of exporting into these countries, by procuring cheaper intermediate products and manufacturing their vehicles within the region. Given that Japanese automotive firms view the North American and EU countries as their main target markets, it is questionable if they will find it worthwhile to build an additional manufacturing or assembly plant in Singapore with the express purpose of penetrating an ASEAN market whose demands for Japanese vehicles can be adequately provided for by the Japanese firms' existing plants in ASEAN.

The extreme case that these Japanese automobile firms will decide to establish manufacturing or assembly plants in Singapore in order to take advantage of the JSFTA and AFTA is even more remote. This is as there are no motor vehicle manufacturing or assembly plants in Singapore; given the government's push to develop high value-added light manufacturing industries like electronics, it is unlikely to encourage the development of a car assembly or manufacturing plant in Singapore. Moreover, the high labor costs and land prices in Singapore will inflate the costs of production to reduce or even eliminate whatever cost savings made from the lower tariff payments under CEPT.

More importantly, the CEPT scheme is carried out on a quid pro quo basis, where a member can only enjoy the preferential tariff if it reciprocates such tariff reduction. Singapore has placed motor vehicles on its General Exceptions List in AFTA, ${ }^{14}$ and as a result, it is allowed to maintain its existing tariffs on motor vehicle imports from ASEAN countries. Thus, any automotive exports from Singapore to the other AFTA economies will not benefit from the CEPT scheme at all. This effectively eliminates any backdoor to AFTA for Japanese firms, as they will face the same tariff rates whether they export from Japan or Singapore.

Given all the above factors, the JSFTA is unlikely to offer any profitable 


\section{Singapore's extra-ASEAN free trade agreements}

backdoor entry for Japanese automotive firms that wish to circumvent the high tariffs in the other ASEAN countries by using Singapore. ${ }^{15}$

\section{Is Singapore leaving its neighbors behind?}

As we see from the preceding discussion, the major economic reason for ASEAN's lukewarm attitude to the JSFTA, and Singapore's other FTAs in general, is more likely to be unsubstantiated. The core of their displeasure may lie in a less tangible domain. This is described succinctly by an editorial in Malaysia's national newspaper, Berita Harian. It commented that "Singapore may not have done any wrong in legal terms but morally, the republic's action showed that it had undermined friendship in ASEAN" (Agence France Presse 25 November 2000). In seeking to enhance the bilateral relationship with countries outside the region, Singapore's actions have been perceived as forsaking its less prosperous neighbors and, in the former Indonesian president's words, "just look[ing] after themselves" (The Business Times 27 November 2000).

In a sense, as Singaporean Prime Minister Goh acknowledged, such accusations are "right up to a point". Singapore has long expressed its worries that the Southeast Asian region is being relegated to the position of an "Asian backwater", since ASEAN countries have yet to recover their pre-financial crisis vibrancy, while Northeast Asia continues to enjoy brighter growth prospects. Coupled with the trend towards the creation of FTAs in other parts of the world, Singapore's initiatives to establish stronger bilateral relations with extra-regional countries are more out of necessity than choice. Given that the stability of its relations with its neighbors will have a significant impact on its future, it is imperative for Singapore to seek a balance between its attitude of hard-nosed pragmatism and the sensitivities of its neighbors. It has attempted to do so by highlighting the positive impacts that its FTAs can have on its neighbors. However, as mentioned above, the JSFTA will probably offer little marginal benefits to ASEAN countries, while the spillover effects are neither guaranteed nor highly quantifiable. As such, Singapore may have to continue to raise the profile of the various strategies that demonstrate its commitments to the region, such as direct investments in these countries, ${ }^{16}$ and the provision of soft-loans to the countries in need, through the Asian Development Bank's soft-loan window. Nonetheless, given Singapore's image as the "brainy kid classmates love to hate, but who some secretly admire" (Asiaweek 8 December 2000), such political rhetoric by the neighbors is probably unavoidable, and the country will just have to take it in its stride.

\section{Conclusion}

Based on the analysis of recent developments, it seems that the Asian crisis of 1997-1998 has not totally undermined the ASEAN countries' resolve to 
realize their vision to establish a regional free trade area despite the shortterm negative implications of trade liberalization. Already significant progress has been made in the implementation of their trade liberalization commitments under AFTA, despite the growing economic and political difficulties faced by some member countries engendered by the recent economic crisis and other inherent structural and institutional weaknesses. A unilateral liberalization process in ASEAN has also begun, particularly in the previously high tariff economies of Indonesia, the Philippines and Thailand. This has resulted in the harmonization of tariff structures to a considerable degree. Deregulation and privatization have also complemented this trend. However, the second phase of economic integration poses a more challenging and difficult task due mainly to the significant differences that exist within these countries in terms of economic development, national priorities and levels of efficiency.

Singapore's recent initiatives to forge extra-ASEAN free trade agreements would not in any way undermine ASEAN's economic integration and its future. The fear that Singapore could be used as a backdoor entry into the ASEAN market has not been substantiated based on the available evidence. Nor should these extra-ASEAN free trade initiatives by Singapore be interpreted as deserting ASEAN. Regionalism presents opportunities for enlarging existing markets and other economic spillover effects of trade liberalization; more importantly, it is crucial for maintaining regional peace and security, which is essential for long-term economic progress and security. Regionalism is especially important for Singapore, which is highly reliant on the region for its water and food supply. It is, therefore, against its strategic interests to ignore the importance of regionalism in favor of forging economic alliances with other countries.

As for the specific impact of the JSFTA on ASEAN, it may result in marginal economic gains for these countries, as there could be some spin-offs for the ASEAN countries if the cooperation efforts between Singapore and Japan under their trade pact are successful. Though there is no guarantee that the agreement will not have negative effects for ASEAN, it is in my view fairly safe to believe that the concerns over significant adverse effects on ASEAN are grossly exaggerated.

\section{Notes}

1 ASEAN, or often referred to as ASEAN10, means Association of Southeast Asian Nations which comprise 10 Southeast Asian countries including Brunei, Indonesia, Malaysia, the Philippines, Singapore, Thailand, Cambodia, Lao Peoples Democratic Republic, Myanmar and Vietnam. Established in 1967, this regional grouping has the objective of promoting political, economic and social cooperation among its members.

2 There are also other concerns including Malaysia's refusal to include the motor vehicles industry in the liberalization under AFTA. 


\section{Singapore's extra-ASEAN free trade agreements}

3 The ASEAN6 countries are the six old members of ASEAN, namely Brunei, Indonesia, Malaysia, the Philippines, Singapore and Thailand.

4 Under the Common Effective Preferential Tariffs (CEPT) scheme of AFTA, the ASEAN founding countries have agreed to reduce tariffs on all commodities traded within the member countries to between 0 and 5 percent ad valorem, by the year 2002, except for a few commodities for national security reasons, protection of public morals, human, animal and plant life and health, and the protection of articles of artistic, historic or archaeological value. For a country to avail itself of these preferences, the principle of reciprocity applies.

5 The ASEAN4 countries are the four newer members of ASEAN, namely Cambodia, Lao Peoples Democratic Republic, Myanmar and Vietnam.

6 The choice of the Japan-Singapore FTA, rather than the New Zealand-Singapore FTA, is because Japan is one of ASEAN's major trading partners and source of foreign investment.

7 For more detailed discussions of Singapore's motivations to forge free trade agreements beyond the region, see Rajan et al. (2001).

8 On 12 October 2001, Japanese and Singaporean officials finally agreed on the provisions for the proposed free trade agreement between their two countries after a series of negotiations. Formally known as the Japan-Singapore Economic Agreement for a New Age Partnership, this FTA was officially signed by the respective governments in early 2002 and has been in operation since the middle of 2002. This is Singapore's second FTA outside the region while the first for Japan. The FTA will also cover non-trade sectors including investments, services and customs procedures with cooperation in tourism and other fields (The Straits Times 13 October 2001).

9 The e-ASEAN initiative is a bold move by the regional grouping to link their markets electronically, hence creating a "seamless" market of 500 million people.

10 It has been reported that both the Philippines and Thailand are pursuing similar free trade initiatives with Japan.

11 In practice, however, there are problems with the implementation of the rules of origin in many countries due to the inadequacy and poor quality of institutions, with poor bureaucracy, lack of transparency and so on.

12 This is a scheme through which ASEAN members seek to progressively lower the effective tariff levels between their countries, with the aim of reducing or eliminating the tariffs on various categories of goods such as manufactured products, pharmaceuticals, vegetable oils, etc. (ASEAN Secretariat 1993).

13 These are stout and porter, beer and ale, and medicated and other forms of samsoo (alcohol).

14 High taxes on motor vehicles are a vital tool in Singapore's supply management policy of its vehicle population, and it is unlikely that the country will allow any exceptions for any free trade agreement that it enters.

15 However, this possibility of trade deflection cannot be fully ruled out for other goods and services, since under AFTA, the rest of the ASEAN members will have to lower their duties to exports from Singapore. These lower duties could be significant enough to more than offset the costs of trade deflection.

16 Singapore has been among the top investors in Indonesia, Malaysia, Thailand, Myanmar and Vietnam.

\section{References}

Agence France Presse (25 November 2000) "Malaysia denies free trade plan, slams Singapore". 
(26 January 2001) "Singapore rejects selfish image, sees itself as an equal".

ASEAN Secretariat (1993) AFTA Reader, Jakarta: Association of Southeast Asian Nations.

(1997) AFTA Reader, Jakarta: Association of Southeast Asian Nations.

(2002) unpublished photocopy.

Asiaweek (8 December 2000) "Keeping up with the Singaporeans", 22.

Dow Jones International News (2 January 1999) "Vietnam Prime Minister: 1999 is pivotal year for nation".

JICA (2004) "Background of Japan-Singapore partnership program for the 21st century", Tokyo: Japan International Cooperation Agency. Online. Available at: <http://www.jica.go.jp/singapore/jspp.html> (accessed 18 February 2004).

Low, L. (2000) "Regional trade agreements: case for Japan-Singapore FTA", Research Paper Series, National University of Singapore, Singapore.

MTI (2004) "Economic management", Singapore: Ministry of Trade and Industry. Online. Available at: <http://www.mti.gov.sg > (accessed 18 February 2004).

Rajan, R., Sen, R. and Siregar, R. (2001) Singapore and Free Trade Agreements: Economic Relations with Japan and the United States, Singapore: Institute of Southeast Asian Studies.

Schott, J.J. (1991) "Trading blocs and the world trading system", The World Economy, 14: 1-18.

The Business Times (27 November 2000) "Will Indonesia break ranks with ASEAN?". - (21 February 2001) "Next WTO chief endorses Singapore free trade deals".

The Economist (14-20 November 1998) "Hands to the plough", 29-30.

The Straits Times (13 October 2001) "Singapore and Japan sew up historic freetrade deal", 4.

Yoshino, F. (2000) "ASEAN in APEC", in S. Sueo and N. Makito (eds) Road to ASEAN10: Japanese Perspectives on Economic Integration, Singapore: Institute of Southeast Asian Studies. 


\title{
8 Prospects for Asian monetary cooperation: pipedream or possible reality?
}

\author{
Peter Wilson
}

\section{Introduction}

The idea that East Asian countries would commit themselves to a monetary union in the foreseeable future is absurd. But the prospects also looked quite bleak for European monetary union (EMU) at the height of the currency crisis in September 1992, when the exchange rate mechanism of the European monetary system (EMS) appeared to be falling apart under the strain of currency speculation; many of the citizens of prospective EMU countries were having second political thoughts about voting in favor in the referendums, which were mandatory under the Maastricht Treaty, to ratify the transition to full monetary union on 1 January 1999. Sweden, Denmark and the United Kingdom opted out altogether until the dust settled. Even ardent supporters of enhanced monetary and exchange rate cooperation in East Asia are not expecting rapid progress towards a monetary union.

Paradoxically the Asian financial crisis of 1997-1998 increased economic disparities in the region, thus making monetary integration more difficult, but rekindled political interest in Asian monetary and exchange rate cooperation. The crisis reduced the credibility of the unilateral fixing of exchange rates and increased the attraction of a common currency arrangement. The perceived failure of international organizations, such as the International Monetary Fund (IMF), to foresee the crisis and deal effectively with it, led to calls for some sort of regional monetary fund, and the negative spillover and currency contagion effects on countries which appeared to be in reasonably sound shape economically before the crisis, such as Malaysia, also catalyzed efforts to devise specifically regional mechanisms of crisis management. It is thus an opportune time to reassess the prospects for monetary and exchange rate cooperation in East Asia.

We begin in the next section with some background on monetary and exchange rate cooperation before and after the Asian crisis, and look at the case for an Asian Monetary Fund. This is followed by the question as to how far East Asian countries, or a subset such as the Association of 
Southeast Asian Nations (ASEAN), satisfy the economic and political prerequisites for some kind of longer term monetary integration. We finish with a discussion of the specific issue of exchange rate cooperation and a brief conclusion.

\section{Background}

\section{East Asia or ASEAN?}

As a general rule, the benefits of monetary integration are greater, and the costs lower, for countries which have similar levels of income and economic development. Given the diversity of East Asia (Table 8.1) we are confronted at the outset with a tricky sample selection problem.

By the 1990s ASEAN had itself emerged as one of the fastest growing regions in the world. Real GDP grew at about 6 percent between 1985 and 1995 on an annual average basis, compared to the world average of 2 percent and growth in developed market economies of 3 percent. Over the same period ASEAN's share of global merchandise trade reached 6.7 percent by the end of 1995 , compared to 3.8 percent in $1985 .^{2}$ This growth was widely shared in the 1990s prior to the Asian crisis amongst both the original ASEAN6 ${ }^{3}$ and the ASEAN4 newcomers of Cambodia, Laos, Myanmar and Vietnam (Table 8.1).

Certainly the ASEAN $10^{4}$ is large enough to generate significant benefits from economic integration, with its total land area of 4.4 million square kilometres and population of approximately 500 million (Table 8.1), but the underlying weakness of ASEAN from its inception in 1967 was its heterogeneous membership. While Singapore espoused export-oriented free trade policies, the other members chose import-substituting industrialization. It is geographically quite disparate, with Indonesia, the Philippines and east Malaysia detached from continental Southeast Asia, and there are significant differences in basic economic indicators (Table 8.1). The richer members in terms of income per capita are Singapore, Brunei and Malaysia, followed by Thailand, the Philippines, and Indonesia and the ASEAN4 countries. Indonesia is a vast country while Singapore is small. Agriculture is dominant in Cambodia, Laos, Myanmar, Vietnam, the Philippines and Indonesia, but negligible in oil-rich Brunei and serviceoriented Singapore.

Moreover, there is little evidence that the gap in income per capita among ASEAN countries has been narrowing. Indeed, according to Park (2000), Theil inequality indices have been widening among both ASEAN10 and the ASEAN5 (ASEAN6 excluding Brunei). The Asian financial crisis has further undermined the shared benefits of economic growth with the emergence of a two-track ASEAN5, with Indonesia, Thailand and the Philippines performing much less well than Malaysia and Singapore.

Even if more formal techniques are applied, it is not at all obvious what 
Table 8.1 Basic economic indicators for East Asian countries, 1997

\begin{tabular}{|c|c|c|c|c|c|c|c|c|}
\hline & \multirow[b]{2}{*}{$\begin{array}{l}\text { Size } \mathrm{km}^{2} \\
(000)\end{array}$} & \multirow[b]{2}{*}{$\begin{array}{l}\text { Population } \\
\text { (millions) }\end{array}$} & \multirow[b]{2}{*}{$\begin{array}{l}\text { GNP per } \\
\text { capita (US\$) }\end{array}$} & \multirow[b]{2}{*}{$\begin{array}{l}\text { Growth 1990- } \\
1997(\%)\end{array}$} & \multicolumn{4}{|c|}{ Share of GDP (\%) } \\
\hline & & & & & Agriculture & Industry & $\begin{array}{l}\text { Manu- } \\
\text { facturing }\end{array}$ & Services \\
\hline Indonesia & 1,812 & 200 & 3,450 & 7.5 & 16 & 42 & 25 & 41 \\
\hline Malaysia & 329 & 21 & 10,920 & 8.7 & 13 & 46 & 34 & 41 \\
\hline Philippines & 298 & 73 & 3,670 & 3.3 & 20 & 32 & 22 & 48 \\
\hline Singapore & 1 & 3 & 29,000 & 8.5 & 0 & 36 & 26 & 64 \\
\hline Thailand & 511 & 61 & 6,590 & 7.5 & 11 & 40 & 29 & 50 \\
\hline Brunei & 6 & 0.3 & 14,301 & - & - & - & - & - \\
\hline ASEAN6 & 2,957 & 358 & 4,798 & 7.1 & 12 & 39 & 27 & 49 \\
\hline Cambodia & 181 & 10 & 1,302 & 6.2 & 50 & 15 & 5 & 35 \\
\hline Laos & 237 & 5 & 1,311 & 6.7 & 52 & 21 & 15 & 28 \\
\hline Myanmar & 678 & 48 & 719 & - & 46 & 16 & - & 38 \\
\hline Vietnam & 330 & 77 & 1,339 & 8.6 & 27 & 31 & - & 42 \\
\hline ASEAN4 & 1,426 & 140 & 1,123 & 7.2 & 44 & 21 & - & 36 \\
\hline ASEAN10 & 4,383 & 498 & 3,768 & 7.1 & 26 & 31 & - & 43 \\
\hline China & 9,326 & 1,227 & 3,570 & 11.9 & 20 & 51 & 40 & 29 \\
\hline Hong Kong & 1 & 7 & 24,540 & 5.3 & 0 & 15 & 7 & 84 \\
\hline Korea & 99 & 46 & 13,500 & 7.2 & 6 & 43 & 26 & 51 \\
\hline Japan & 377 & 126 & 23,400 & 1.4 & 2 & 38 & 25 & 60 \\
\hline
\end{tabular}

Source: World Bank, World Development Report 1998; data for Brunei and Myanmar are from Park (2000).

Notes

GNP per capita is measured at purchasing power parity; growth is in terms of real GDP; the income per capita figures for Brunei and Myanmar are for GDP at purchasing power parity; the sectoral shares for Brunei and Myanmar refer to 1996. 
would constitute a distinct economic grouping in East Asia. Yuen (2000), for example, using hierarchical cluster analysis over the period 1990 to 1997 , placed Japan with a group of mature developed countries with high income per capita, low GDP growth and moderate inflation (Australia, New Zealand, USA). Further clusters included a high-growth Asian group comprising Korea, Malaysia and Thailand, characterized by moderate income per capita, inflation and interest rates; a group of emerging economies (Indonesia, the Philippines) with moderate growth, low income per capita and high inflation; and the small open economies of Hong Kong and Singapore which share the characteristics of the highest income per capita, the lowest interest rates, the highest value-added in services and the lowest value-added in agriculture. A fifth cluster consisted solely of China, which was distinctly different from the rest of the Asian sample!

As a consequence of this sampling problem, empirical work on monetary integration in East Asia has tended to rely on an ad hoc and varying list of countries for which reliable data could be found (Goto and Hamada 1994, Eichengreen and Bayoumi 1998), or on a subset of ASEAN countries (Nicolas 1999, Bayoumi and Mauro 2001). The latter is justified on the grounds that policymakers in ASEAN have expressed an interest in the possibility of closer monetary ties and it is already committed to integration in other areas.

But, as we shall see, the case for ASEAN monetary integration is much weaker than for other subsets of East Asian countries and it is hard to envisage serious monetary and exchange rate integration without the participation of countries such as Japan, China and Korea, if only to provide the financial resources for a regional fund and common exchange rate system. Certainly monetary integration in ASEAN is not a prerequisite to monetary integration in East Asia.

From its inception in 1967 under the Bangkok Declaration, ASEAN has largely been a political organization established essentially to contain the rise of communism in Southeast Asia. It has undoubtedly been successful in containing intra-ASEAN conflict and in providing a forum for the discussion of regional matters, including disputes over territorial claims in the South China Sea, but as a political force it has exerted little influence on the world stage given its heterogeneous character and the decline of the communist threat. The Asian financial crisis has further eroded the political consensus within ASEAN; Singapore, in particular, has tended to look to its own geopolitical interests, which increasingly lie outside ASEAN, by signing bilateral preferential trading agreements with countries outside the region, such as Australia and USA, even if this upsets its ASEAN partners and weakens the solidarity of ASEAN as a trading bloc. ${ }^{5}$

It is widely accepted that apart from providing some common policies on food, energy and tourism, ASEAN achieved little in terms of tangible economic benefits for its members in the first two decades of its existence 
(Wong 1988, Yeung et al. 1999). Much of the gains would probably have been achieved without coordinated initiatives through ASEAN from unilateral trade liberalization after the mid-1980s (Singapore much earlier), driven by private enterprise, inward foreign direct investment, and the mutual benefits from each country having "growing neighbors". Pomfret (1996) has described ASEAN as an "enigma" in Asia by virtue of its longevity as a developing country trading bloc, but "perpetually at the crossroads" in the sense that it fails to deliver and periodically something always needs to be done to revitalize the integration process. Negotiations with China and Japan to establish free trade areas with these countries and proposals for an ASEAN common market by 2020 are recent examples of this revitalization process.

Structural diversity in ASEAN has meant less scope for trade creation in the sense of shifting resources from inefficient to efficient producers within the bloc. Attempts to orchestrate this collectively were doomed to fail as governments resisted closing down their own factories. On the other hand, policies which were trade diverting by restricting lower cost competition from outside to protect infant industries within ASEAN (except Singapore) were politically feasible, but were costly in the longer run by virtue of their inefficiency, and came under increasing threat from advocates of trade liberalization.

Attempts to lower tariff rates collectively through preferential trading arrangements after 1977 were disappointing and hampered by the voluntary listing of products for preferential treatment, and by a cumbersome case-by-case approach. Initiatives to promote industrial cooperation after 1976 also largely failed, a classic example being Malaysia's decision to develop its own integrated automobile industry (Pomfret 1996).

As discussed in Chapter 7 of this book, beginning in 1991, ASEAN members made a concerted effort to speed up the process of tariff reduction by committing themselves to an ASEAN free trade area (AFTA). The AFTA goals were much more credible than earlier preferential tariff arrangements in ASEAN and by 2002 ASEAN6 had succeeded in bringing down tariffs on a wide range of manufactured goods and agricultural products to between 0 and 5 percent (Ministry of Information and the Arts 2002). But there still seems to be a reluctance to fully open up their markets to the final consumer goods of their fellow AFTA members and remove remaining bureaucratic impediments to trade and investment flows. The underlying problem is the same as before: governments are reluctant to lower protection on items which harm vested interests. An ominous sign in November 2000 was a protocol signed by ASEAN Economic Ministers setting up a temporary exclusion list for those countries facing economic difficulties. In March 2001 Indonesia postponed the lowering of import duties and Malaysia has been granted a reprieve until 2005 for its motor industry, which sets an alarming precedent for an important industry in ASEAN. Further tariff cuts were, however, effected in 2002. 
In many ways a more promising political forum from the monetary perspective is the ASEAN+3, established in December 1999, adding China, Japan and Korea to ASEAN. This offers a tantalizing opportunity to strengthen regional bargaining power with the outside world and capitalize on a larger bloc with close trade and investment links. On the other hand, it makes the logistics even less manageable with a wider range of exchange rate and monetary regimes, and further increases the gap between the more developed and less developed countries (Table 8.1) and the potential for greater asymmetries in economic shocks affecting individual members.

\section{Pre-crisis monetary cooperation}

Before the Asian financial crisis there existed only rudimentary monetary and exchange rate cooperation between Asian countries (Chan and Rajan 2001). There had been some discussion about the development of a yen bloc (Taguchi 1998, Kwan 1998, 2000) just as the European monetary system (EMS) had evolved into a de facto Deutsche mark bloc in the 1980s. But there is little evidence that such a bloc had emerged naturally and the idea had been met with a lukewarm political reception, largely because of on-going disputes between Japan and her East Asian neighbors, such as Korea and China, over Japanese war atrocities.

There was also a noticeable absence of any collective defense against currency crises apart from a limited network of bilateral repurchase agreements (repos), some currency swap arrangements and some informal cooperation between regional central banks. In February 1996, for instance, the Monetary Authority of Singapore (MAS) and Hong Kong Monetary Authority intervened to support the yen against the dollar, and in May 1997 the MAS unsuccessfully tried to support the baht. The sums involved in these swap arrangements were also woefully inadequate to counter speculative attacks on Asian currencies. When Thailand called upon a swap arrangement set up during the Mexican crisis of 1994 to shore up the baht in 1997, it did little to stop its fall and was likely perceived as an act of desperation.

Asian monetary cooperation has undoubtedly been complicated by the wide variety of officially declared exchange rate regimes prevalent in East Asia, the lack of transparency as to how these regimes are actually operated, and the different responses of individual countries to the Asian financial crisis itself.

Table 8.2 summarizes East Asian currency arrangements in 1990, 1997, 2001, and their monetary policy positions in 2001, as recorded at the IMF. Compared to Europe in the mid-1970s when the first steps in exchange rate cooperation were being put in place after the breakdown of the Bretton Woods system of fixed exchange rates, one is struck by the variety of Asian forex regimes and monetary policies. Hong Kong has had a hard 


\section{Prospects for Asian monetary cooperation}

fix to the dollar since October 1983 and operates a quasi currency board. Japan floats. In 1990 and 1997 both Singapore and Indonesia are officially managed floating but for Singapore this means managing the Singapore dollar against an unpublished trade-weighted basket with the primary objective of maintaining low and stable inflation by reducing import prices. The Indonesian rupiah, however, seems to be managed in terms of a crawling basket peg to allow the currency to depreciate steadily over time to offset a domestic inflation rate which persistently exceeds that of its competitors. Thailand, on the other hand, officially operated a multicurrency basket peg prior to the crisis but in practice has pegged quite closely to the dollar, ostensibly to maintain export competitiveness. The Philippines and, more recently, Korea, are supposedly floating but their regimes are rather opaque. China, on the other hand, which was supposed to be managed floating since 1990 has, in fact, fixed rigidly to the dollar since the beginning of 1994.

During the Asian crisis there was substantial exchange rate volatility in East Asia (Table 8.3). Non-crisis countries, such as China and Hong Kong,

Table 8.2 Asian monetary arrangements, 1990, 1997, 2001

\begin{tabular}{|c|c|c|c|c|c|c|}
\hline & $\begin{array}{l}\text { Fixed to } \\
\text { a single } \\
\text { currency }\end{array}$ & $\begin{array}{l}\text { Fixed } \\
\text { to a } \\
\text { composite }\end{array}$ & $\begin{array}{l}\text { Managed } \\
\text { float }\end{array}$ & $\begin{array}{l}\text { Indepen- } \\
\text { dent } \\
\text { float }\end{array}$ & $\begin{array}{l}\text { Convert- } \\
\text { ibility }\end{array}$ & Monetary policy 2001 \\
\hline China & 2001 & & $\begin{array}{l}1990 \\
1997\end{array}$ & & Partial & $\begin{array}{l}\text { Monetary target/ } \\
\text { exchange rate } \\
\text { anchor }\end{array}$ \\
\hline Hong Kong & $\begin{array}{l}1990 \\
1997 \\
2001\end{array}$ & & & & Full & $\begin{array}{l}\text { Exchange rate } \\
\text { anchor }\end{array}$ \\
\hline Indonesia & & & $\begin{array}{l}1990 \\
1997 \\
2001\end{array}$ & & Partial & $\begin{array}{l}\text { Fund supported/ } \\
\text { other }\end{array}$ \\
\hline Japan & & & & $\begin{array}{l}1990 \\
1997 \\
2001\end{array}$ & Full & Other \\
\hline Korea & & & $\begin{array}{l}1990 \\
1997\end{array}$ & 2001 & Partial & Inflation target \\
\hline Malaysia & 2001 & 1990 & 1997 & & Partial & $\begin{array}{l}\text { Exchange rate } \\
\text { anchor }\end{array}$ \\
\hline Philippines & & & & $\begin{array}{l}1990 \\
1997 \\
2001\end{array}$ & Partial & $\begin{array}{l}\text { Monetary } \\
\text { target/fund } \\
\text { supported/other }\end{array}$ \\
\hline Singapore & & & $\begin{array}{l}1990 \\
1997 \\
2001\end{array}$ & & Full & Other \\
\hline Thailand & & $\begin{array}{l}1990 \\
1997\end{array}$ & 2001 & & Partial & $\begin{array}{l}\text { Inflation target/fund } \\
\text { supported/other }\end{array}$ \\
\hline
\end{tabular}

Source: International Monetary Fund (various years), International Financial Statistics. 
Table 8.3 Asian exchange rate volatility during the crisis period, June 1997 to December 1998

\begin{tabular}{|c|c|c|c|c|}
\hline & \multicolumn{2}{|c|}{ Standard deviation of changes } & \multicolumn{2}{|c|}{ Cumulative depreciation } \\
\hline & Against US\$ & NEER & Against US\$ & NEER \\
\hline Indonesia & 73.02 & - & 217.93 & - \\
\hline Malaysia & 10.38 & 4.38 & 51.39 & 32.09 \\
\hline Philippines & 7.50 & 3.71 & 48.15 & 31.71 \\
\hline Singapore & 3.42 & 1.41 & 14.58 & 4.93 \\
\hline Thailand & 14.53 & - & 40.16 & \\
\hline China & 0.03 & 1.65 & -0.12 & -2.05 \\
\hline Hong Kong & 0.07 & 1.66 & 0.13 & -3.50 \\
\hline Korea & 15.00 & - & 35.81 & \\
\hline Yen & 4.19 & & -1.16 & \\
\hline Swiss franc & 2.72 & & -4.90 & \\
\hline German mark & 2.47 & & -1.76 & \\
\hline
\end{tabular}

Source: International Monetary Fund, International Financial Statistics.

Notes

All exchange rates are monthly end of period; NEER is the nominal effective exchange rate based on a trade-weighted basket of currencies; a negative sign for the cumulative depreciation implies a cumulative appreciation.

stuck closely to the dollar. Singapore devalued by 15 percent, Malaysia and the Philippines by about 50 percent and Indonesia by a massive 218 percent.

\section{Post-crisis monetary initiatives}

The Asian crisis may have increased economic disparities in the region, but it also renewed political interest in Asian monetary and exchange rate cooperation. There were a number of reasons for this.

To begin with, unilateral exchange rate regimes (including de facto dollar pegging) hadn't worked very well, with the exceptions of Singapore and Taiwan, where success was probably more a function of good macroeconomic fundamentals than the nature of their forex regimes per se. Both countries wisely allowed their currencies to appreciate to some degree in response to the large inflow of capital in the 1990s and so avoided the trap of trying to peg too tightly to the dollar to retain export competitiveness. It helped that this was consistent with their domestic policy priority of price stability.

Other countries, notably Thailand, Indonesia and Malaysia, eventually succumbed to the "triad of incompatibilities", namely the difficulty, if not impossibility, of juggling three economic policy objectives in the air at once: "managing the currency" (in effect dollar pegging), retaining some 
autonomy in domestic monetary policy, and integrating with international capital markets through partial or full currency convertibility (Kwan et al. 1998). Their response to the inflow of capital in the 1990s was to stop it from appreciating the real effective exchange rate (REER), which would have eroded export competitiveness, by buying foreign assets and simultaneously sterilizing the impact of the inflow on the domestic money supply (and thus on goods and asset markets) by issuing domestic assets. This was done quite successfully for some time before the bubble burst. Dollar pegging made this harder since it encouraged undesirable unhedged short-term capital inflows by creating the perception that the central bank would defend the rate against the dollar come what may, so loans could safely be repaid in dollars at a more or less fixed rate. The "corner solutions" of a hard peg or a free float, which were mooted in the immediate aftermath of the crisis, were not particularly palatable to Asian governments, as we shall see in the section on Asian exchange rate mechanisms below, so the search for a cooperative exchange rate solution became a more attractive option than it might have been prior to the crisis.

The crisis had also shown the extent to which East Asian economies had become integrated into global goods and factor markets in the 1990s, as they liberalized their foreign trade regimes and opened up their domestic markets to both short-term and long-term international capital. The counterpart of this increased interdependence with each other and with the rest of the world was greater exposure to spillover effects across national boundaries, including financial contagion and trade effects as changes in nominal exchange rates affected relative competitiveness and trade flows. Insofar as these effects are externalities which could not be internalized by any one country individually, they reinforce the view that national policies need to be supplemented with cooperative solutions at the international or regional level, including regional resource pooling and crisis management policies.

The attractiveness of an international solution had been diminished by the perception that international organizations, such as the IMF, had failed to anticipate the crisis, in spite of extensive early-warning machinery, had wrongly diagnosed it as a "Latin-American" style structural crisis, rather than as a capital account crisis made worse by weaknesses in financial and corporate governance, and had applied the wrong remedy, notably to Indonesia, by being slow to disburse funds and imposing excessive conditionality on the loans that were eventually given. If these financial problems are shared within the region then a regional response to financial crises becomes appropriate. The success so far of EMU, despite doubts about its suitability as an optimum currency area, has probably also given some encouragement to advocates of Asian monetary integration. The result has been a spate of post-crisis initiatives to explore monetary and exchange rate cooperation, or to "evolve the regional financial architecture". 
In September 1997, much to everyone's surprise, Japan proposed an Asian Monetary Fund (AMF) to pool regional funds for quick disbursement in an emergency. The support from other potential creditor countries, such as Singapore and Taiwan, was not discouraging, and the opportunity to devise a multilateral Asian forum was welcomed at the political level by Malaysia and Indonesia, as a possible counterbalance against the Western countries in general, and Washington in particular.

The Japanese proposal was met, however, with strong resistance from both Washington and the IMF. The latter objected on the grounds that such a fund would merely duplicate the facilities available at the Fund itself, it would serve only to undermine the IMF through "soft" conditionality and would exacerbate the moral hazard problem as a regional lender of last resort. It would be better, suggested the IMF, for East Asia to focus instead on structural reforms and the establishment of surveillance and monitoring machinery which would complement rather than compete with the IMF. ${ }^{6}$

American and IMF pressure prevailed and the AMF was shelved for the time being. As an alternative, the Manila Framework Group was set up in November 1997 to enhance trans-Pacific monetary cooperation. Finance Ministers and representatives from 14 central banks from countries both within and outside the Asia-Pacific region agreed to meet twice a year, with the Asian Development Bank (ADB), the IMF and the World Bank providing surveillance reports.

More important, from the perspective of Asian monetary cooperation, was the meeting of the finance ministers of the ASEAN +3 on the sidelines of the Annual Meeting of the ADB in Chiang Mai in May 2000. The idea of an AMF may have been lost, but in what subsequently became known as the "Chiang Mai Initiative", the ASEAN+3 agreed in principle to establish a pool of hard currencies to be used in times of crisis and to explore the possibility of setting up surveillance machinery to anticipate future crises.

This culminated in May 2001 at the ADB meeting in Honolulu, which dropped the idea of a common pool of hard currencies but expanded the existing ASEAN repos and swap arrangements to ASEAN+3, thereby creating a regional network of bilateral repos and currency swaps. Bilateral repos allow participating countries to obtain short-term liquidity through the sale and buyback of US Treasury bills or notes. Currency swaps enable countries to swap "soft" for "hard" currencies if the home currency is under attack. Initially the sum involved was US\$6 billion, with bilateral deals signed between Japan and Malaysia, Japan and Korea, and Japan and Thailand. Others are due to be negotiated in the future (Rana 2002).

The sums involved are quite small compared to the daily flow of funds through the foreign exchange markets and constitute a pool of liquidity denominated in dollars rather than a common fund denominated in a common currency. The swaps are also complementary to IMF lending rather than a substitute for it, since disbursement is conditional upon the 
country also accepting an IMF program for macroeconomic and structural assistance, except for 10 percent of the swap agreement, which can be granted automatically during a crisis.

Nonetheless, monetary cooperation is on the move in the sense that the swaps and repos consolidated in Honolulu constitute the beginnings of a regional financing facility, maybe even an embryonic AMF, and a symbolic first step towards monetary cooperation. It is reminiscent of the General Arrangements to Borrow (GAB) in the early 1960s, which allowed the IMF to borrow from the ten major industrial countries in order to assist countries with balance of payments deficits. This was the first time the IMF had borrowed to supplement its resources and was the forerunner of other borrowing arrangements, such as the oil facilities in the 1970s, and it had an important political dimension by promoting consultation among the Group of Ten countries. In addition, swaps involve real credit risk, as opposed to repos which are essentially hard currency loans with US government securities as collateral. Significantly, China has not objected to the concept of an AMF or the increasing use of the yen in swap agreements, and a yen-renminbi swap is expected to be introduced soon for the first time. We live in interesting times.

ASEAN and ASEAN +3 are also pressing ahead with their own IMF-style surveillance and monitoring machinery. Under the ASEAN +3 Surveillance Process finance ministers and the Secretary General meet twice a year for policy coordination. The ASEAN Surveillance Process was set up in October 1998 to strengthen policy-making capacity through peer reviews, and is supported by a new Regional Economic Monitoring Unit (REMU) at the ADB to support monetary and financial cooperation in Asia, together with an Asia Recovery Information Center (ARIC), a dedicated internet-based clearinghouse of information on the Asian recovery established in November $1999 .^{7}$ An early warning system has also been developed at the ADB.

From the exchange rate point of view, under the Hanoi Plan of Action in December 1998, ASEAN leaders had agreed to study the feasibility of a common currency and exchange rate system, but a key development was the January 2001 Third Asia-Europe Meeting (ASEM) of finance ministers which agreed to set up the Kobe Research Project. This is an on-going project at Kobe University in Japan's APEC Study Center to facilitate interregional cooperation and research and study activities on topics of mutual interest, such as regional and monetary cooperation, exchange rate regimes and public debt management. ${ }^{8}$ The idea is to strengthen economic, cultural and political ties with Europe and to draw on European experience in regional cooperation, including the feasibility of a common exchange rate system modelled along European lines. We shall come back to this later on. 


\section{An Asian Monetary Fund?}

Why not an AMF? Notwithstanding opposition by the IMF and Washington to an independent AMF, the idea of a regional fund is gaining some support, especially amongst those who are impatient with the pace of reforms to the international financial architecture. ${ }^{9}$ It could be a new institution, or a manifestation of existing ones such as the ASEAN Secretariat or ADB. It could be capitalized by reserve contributions from its members according to some formula, and members could borrow multiples of their original contributions. It might act as a lender of last resort, or simply promote regional monetary cooperation and provide surveillance and early warning machinery for future financial crises.

Whilst capitalizing such an institution might have been a little daunting in the past, Asian countries now have substantial resources at their disposal, particularly Japan, China and Singapore, partly because of rapid growth in their foreign exchange reserves in the 1990s (Table 8.4). All that is required is a willingness to pool them to take advantage of economies of scale and some machinery for affecting the transfer. The total official foreign exchange reserves of ASEAN8+3 exceeded US $\$ 700$ billion in 1999, compared to US\$200 billion in 1990. Even ASEAN8 (excluding Brunei and Cambodia) had reserves exceeding US $\$ 180$ billion. Moreover, in 1997, prior to the transfer of reserves by EMU countries to the European Central Bank, the ASEAN8+3 had higher reserves than the founding members of EMU (Table 8.4).

Surely an AMF can't be any worse than the IMF in dealing with the Asian region? Certainly it would run the risk of becoming a "soft option" as far as conditionality is concerned, and it would be subject to political pressures in the region against the implementation of unpopular policies. It might also exacerbate the problem of moral hazard in lending matters, but similar arguments have been levied against the IMF in the past. On the other hand, an AMF might, by virtue of its location, be better informed on issues of direct relevance to the region, be willing and able to respond more quickly to regional crises, and would be less susceptible to Washington-based political interference. The Chiang Mai Initiative was a useful first step towards augmenting regional resources but the sums involved are small and its scope for action is severely limited by the bilateral nature of the arrangements and the dominance of IMF conditionality. A permanent AMF would be a better solution.

The view that a regional solution, including Asia-specific conditionality, might be better is also strengthened if the causes of the Asian crisis are traced, not so much to Latin American weaknesses in macroeconomic fundamentals (high inflation, large budget deficits, unsustainable current account deficits) but to premature financial sector liberalization, weaknesses in financial markets and in corporate governance, and mistakes in the management of international capital flows which left countries susceptible to financial 
180 Prospects for Asian monetary cooperation

Table 8.4 International reserves, 1990, 1997 and 1999

\begin{tabular}{|c|c|c|c|c|}
\hline \multirow[t]{2}{*}{ Country } & \multicolumn{3}{|c|}{ Total reserves (US\$ billions) } & \multirow{2}{*}{$\frac{\text { Increase in reserves (\%) }}{1990-1999}$} \\
\hline & 1990 & 1997 & 1999 & \\
\hline Indonesia & 8.7 & 17.5 & 26.4 & 203 \\
\hline Malaysia & 10.7 & 21.1 & 30.6 & 186 \\
\hline Philippines & 2.0 & 8.7 & 13.2 & 560 \\
\hline Singapore & 27.7 & 71.3 & 76.8 & 177 \\
\hline Thailand & 14.3 & 26.9 & 34.1 & 138 \\
\hline Laos & 0.08 & 0.15 & 0.10 & 25 \\
\hline Myanmar & 0.41 & na & 0.65 & 59 \\
\hline Vietnam & 0.43 & 1.9 & 2.00 & 365 \\
\hline ASEAN8 & 64.3 & 147.6 & 183.9 & 186 \\
\hline China & 34.5 & 146.7 & 158.0 & 358 \\
\hline Korea & 14.9 & 20.5 & 74.0 & 397 \\
\hline Japan & 87.8 & 227.0 & 286.9 & 227 \\
\hline ASEAN8 + 3 & 201.5 & 541.8 & 702.8 & 249 \\
\hline Hong Kong & 24.7 & 92.9 & 96.2 & 289 \\
\hline Taiwan & 77.7 & 87.4 & 106.2 & 37 \\
\hline USA & 173.1 & 134.9 & 60.5 & -65 \\
\hline Switzerland & 61.3 & 63.2 & 36.3 & -41 \\
\hline EMU & 446.3 & 432.9 & 254.6 & -43 \\
\hline
\end{tabular}

Source: World Bank (various years), World Development Report.

Notes

Reserves are gross and comprise: holdings of monetary gold valued at the year-end London price of US\$290.25, Special Drawing Rights, reserves held at the International Monetary Fund, and holdings of foreign exchange under the control of the monetary authorities; EMU consists of 11 members of the European Monetary Union.

panic and destabilizing currency flows. A solution to this, which could be orchestrated by an AMF, might be to develop a regional bond market to stem the flow of savings invested outside of the region only to be recycled back as short-term bank loans in foreign currency, which was a potent source of instability in the build up to the Asian crisis.

The globalization of goods and factor markets in the last two decades has substantially increased interdependence and externality effects across national boundaries, such as financial contagion, which supports the case for supplementing national policies with regional initiatives, since one country alone cannot fully internalize these spillover effects. ${ }^{10}$ As Rose $(1999,2000)$ has argued, currency crises tend to be regional and spread via trade links thus disrupting regional trade flows. An AMF would be one way to mitigate these effects.

One might argue that it would be better for East Asia to focus on financial and corporate reforms and crisis prevention measures which are 
complementary to the IMF, while the necessary economic and political preconditions are set in place for closer monetary union. But there is still a good case for increasing monetary and exchange rate cooperation now. An AMF would actually be quite an easy first "baby" step since it would be an extension of the current activities of the ADB and ASEAN Secretariat and it need not be based on a specific hegemon such as Japan, or require a yen bloc, or prior evidence that East Asia is an optimum currency area (discussed in the next section); and it need not be evolved in the first instance from membership in a regional trade bloc such as ASEAN. Indeed, it would be more logical to start from ASEAN +3 or some other configuration which includes the richer Asian countries, since they would be able to provide the necessary reserves to capitalize the fund. It would also be a crucial first step to institutionalize change in East Asia by building on the post-crisis political goodwill (and the 2002 World Cup shared between Korea and Japan!) to begin the process of constructing self-help mechanisms to prevent future crises, and a regional forum for arguing about East Asian monetary and exchange rate affairs. As the Malaysians might put it: "Asia boleh" (Asia can do it). Although Europe has a long history of institution building at the supranational level, experiments with exchange rate coordination in the 1970s (often acrimonious and unsuccessful) required forums in which economists and politicians could argue with one another and vent their feelings against "outsiders", usually the USA, in order to develop something distinctly "European".

In this sense the decision to shelve the idea of an AMF was probably a mistake, but explicable in the context of Japan's ambivalence towards the USA and its rather uneasy position in the geopolitical landscape of East Asia, where there are old problems to be solved regarding multiple claims over territories in the South China Sea and a good deal of resentment still about Japan's refusal to address the issue of its World War II atrocities in the region (especially in Korea and China) in the same manner as Germany has done. China's entry into the WTO and emergence as a formidable political power has also created political uncertainties and a degree of rivalry between Japan and China with respect to influence over events in the rest of East Asia, which might complicate steps towards monetary and exchange rate cooperation, but need not preclude it.

\section{An Asian monetary union? ${ }^{11}$}

\section{The optimum currency area}

In the original Mundellian (1961) sense an optimum currency area (OCA) exists when the benefits of fixing exchange rates exceed the costs. This need not necessarily be defined by common geographical boundaries since it could take the form of a common anchor to a specific currency and thus a common monetary policy. A monetary union would then be an 
extreme form of monetary integration where there is a common currency and central bank.

The microeconomic benefits of an OCA to its members include the increased allocative efficiency arising from the saved transaction costs of currency conversion, the elimination of currency risk and hedging costs within the bloc, and economies of scale in the holding of foreign exchange reserves if a common central bank replaces the banks of individual countries. It may also promote a single integrated market if barriers between the regions are removed and foreign investors perceive the union as a single market and take advantage of economies of scale. Macroeconomic gains might include a reduction in inflation and inflationary expectations if the common monetary policy is disciplined and credible, a reduction in risk-adjusted real interest rates as currency risk is eliminated and expected inflation falls, and the elimination of the intra-bloc social costs of floating exchange rates (destabilizing speculation, exchange rate uncertainty, currency overshooting) if exchange rates are permanently fixed.

The costs of an OCA are generally associated with the "economic stabilization loss" or extra instability in output resulting from the giving up of the exchange rate as a macroeconomic tool for individual countries. There may also be one-time costs as high inflation countries converge to a common interest rate structure and inflation rate. More persistent costs could arise from difficulties in the application of a common monetary policy, especially if individual economies are subject to frequent asymmetric shocks. For example, countries with high inflation and low unemployment may require high nominal interest rates, and vice versa for countries with high unemployment and low inflation. Fiscal externalities may also arise if, for example, a "large" country within the bloc embarks on an undisciplined fiscal expansion thus generating inflationary pressures for the bloc as a whole, and negative effects on trade balances as a result of an unwanted appreciation of the common currency.

A number of criteria have been put forward to help decide whether a group of countries actually constitute an OCA. The assumption is that OCAs are more likely to succeed if member countries are closely linked by trade in goods and services and by factor mobility, or there is evidence that convergence will occur quickly in the future.

The "early" Mundell (1961) stressed the need for sufficient factor mobility (particularly labor) to enable countries to adjust to asymmetric output shocks without resorting to the exchange rate. A classic example would be the widespread adoption of more flexible exchange rates after the first oil shock in 1973. McKinnon (1963) emphasized the importance of openness (high proportion of traded to non-traded goods); giving up the exchange rate instrument would be no cost since the expenditureswitching effects of depreciation would in any case quickly pass through to higher domestic prices and wages and offset any competitive advantage 
from the original devaluation or depreciation. Moreover, since small countries tend to be more open, they will, ceteris paribus, lose less from monetary integration. Kenen (1969) pointed out that a high degree of product diversification would be a positive factor since OCA members would be more likely to have a diversified portfolio of jobs and thus be less susceptible to industry-specific shocks.

The problem with single criteria is that they may conflict (Tavlas 1994): a country may be very open to trade but at the same time have a low level of labor mobility. Multiple criteria adopt a more explicit cost-benefit approach. Bayoumi (1994), for example, neatly incorporated Mundell, McKinnon and Kenen criteria into a general equilibrium model of the OCA.

Whilst OCA criteria provide a basis for assessing the costs and benefits of monetary integration, they are not strictly necessary, providing there is sufficient endogenous convergence and political will. This is important when assessing the prospects for an Asian Monetary Union. As Frankel and Rose (1998) pointed out, countries are more likely to satisfy OCA criteria $e x$ post and historical extrapolation can be misleading. High inflation countries, for example, may be more willing to join a monetary union precisely because it will enable them to bypass domestic political constraints and gain the credibility of the common central bank. Indeed, if the Maastricht convergence criteria were strictly applied in 1996 (Wilson 1998), Portugal, Spain and Italy failed on price stability, and only Finland, the Netherlands, Luxembourg and Ireland passed on budget deficits. One year later, all 11 future members passed on interest rates, price stability and budget deficits, and were within the widened band of the exchange rate mechanism (ERM). All failed, however, in terms of the debt-to-GDP ratio except France, Finland and Luxembourg. By January 1999, when EMU was born, short-term interest rates had stabilized at around 3.5 percent, spot and forward exchange rates had converged on their central parities in the ERM and the Maastricht tests had been passed as far as price stability and current budget deficits were concerned (with some creative accounting in the case of budget deficits), but not in terms of government debt.

OCA criteria are thus not set in tablets of stone. Although Mundell in 1961 worried that countries which were dissimilar would not be able to have a common monetary policy in the face of asymmetric shocks, he later realized that this doesn't make sense for highly diversified industrial countries producing a wide range of goods and he appears to have changed his mind in Mundell (1973). Heterogeneous economies could share the risks from asymmetric shocks better within a common currency area as long as there were international portfolio diversification in capital markets so a country which suffered an adverse shock could easily borrow from other countries in the currency area and so share the risks of asymmetric shocks. A good argument for adopting the euro in EMU was precisely that it 


\section{Prospects for Asian monetary cooperation}

would encourage greater portfolio capital diversification in the euro area, and this has already happened. It is not, however, imminent in East Asia.

\section{Is Asia or a subset of countries, such as ASEAN, an optimum currency area?}

There is pretty much universal agreement, even amongst those who are in favor of further monetary and exchange rate cooperation in East Asia, that Asian monetary union is a long way off in terms of a significant pooling of sovereignty into common institutions, and the adoption of a common exchange rate mechanism. Neither is East Asia or ASEAN an OCA according to the strict criteria discussed above. But, notwithstanding the sample selection problem adhered to earlier, there is some disagreement as to how far East Asia or a subset of its countries satisfies the economic criteria for an OCA. This is important not simply because it will affect the political agenda for countries contemplating further monetary integration, but because some minimum prerequisites in terms of economic integration are necessary for the development of common monetary institutions. As we shall see below, advocates of a common East Asian exchange rate policy, such as Williamson (1998) and McKinnon (2000), do assume that East Asian countries are sufficiently close as trading partners and competitors in world markets to justify a common monetary arrangement. If this is not the case then the case for giving up unilateral exchange rate regimes is significantly weaker.

Empirical work on East Asia and ASEAN has been a mixture of an ad hoc application of the single OCA criteria and more formal modeling of the magnitude and characteristics of the supply-and-demand shocks affecting countries over time. The case for an OCA is strengthened where there is substantial cross-border trade and factor flows, a degree of similarity or convergence in the levels and behavior of key macroeconomic indicators relevant to a common monetary policy ${ }^{12}$ and where there is evidence of small and synchronized supply-and-demand shocks, fast adjustment to shocks, and common business cycles.

Building on earlier empirical work by Goto and Hamada (1994), and Bayoumi and Eichengreen (1994), which was quite supportive of the case for monetary integration in East Asia, Eichengreen and Bayoumi (1998) came to the surprising conclusion that nine East Asian countries satisfied the standard economic criteria for an OCA almost as well as Western Europe so a common currency peg would benefit its small open economies, although domestic financial systems were less well diversified so a common currency peg would be risky. East Asia also lacked the institutional framework and political preconditions to make a peg work, so it risked being unstable.

As far as ASEAN specifically was concerned, Bayoumi and Mauro (2001) suggested that it was less suitable for monetary integration than 
Europe just prior to the Maastricht Treaty, since the latter had achieved a much higher degree of economic integration and had greater political will and the necessary institutional structures, but the economic differences were not that large.

Some researchers, including the present author, are more skeptical about the extent to which East Asia or ASEAN satisfy the minimum economic criteria for an OCA. One persistent theme is the lack of similarity in levels of economic development and lack of convergence in income per capita discussed earlier under the sample selection problem. Nicolas (1999), for example, has argued that similarity in ASEAN countries has been exaggerated because of high levels of aggregation. ASEAN5 countries appear similar since all are manufacturers and traders, but they are much less similar within manufacturing. The only strong similarity in export structures is between Singapore and Malaysia, and ASEAN5 countries are not very well diversified in production. Half of Singapore's manufacturing is in electronics and non-electronic machinery and 13 percent in petrol refining, while the Philippines and Malaysia are concentrated in food products and electrical machinery.

The magnitude of intra-Asian trade is also controversial. There has undoubtedly been an increase in intra-regional trade in East Asia since the beginning of the 1980s, and by 1998 intra-ASEAN trade as a percent of regional GDP is similar in magnitude to the European Union (EU) and higher than for MERCOSUR and NAFTA ${ }^{13}$ (Table 8.5), but this is largely because East Asian countries are exceptionally open and intra-ASEAN trade is much lower as a percent of total bloc trade (Table 8.6). Much of ASEAN's trade and investment is with Asian countries outside ASEAN, including Japan and the other newly-industrialized countries, and intrabloc trade is much less if Singapore is excluded from the trade matrix (Table 8.6) and allowance is made for re-exports, particularly between Singapore and other ASEAN countries. ${ }^{14}$

Others have questioned the assumption that faster adjustment to supply shocks in East Asia can be attributed to more mobile cross-border labor movements. It is true that labor markets are generally more flexible than in Europe but the large proportion of the foreign workers in the labor forces of Singapore, Malaysia and Hong Kong are by and large oneway movements of unskilled workers from the poorer countries in the region, such as Indonesia and the Philippines, in search of higher wages, rather than the symmetric short-term adjustment mechanism implied in the Mundell (1961) criterion. Singapore, for instance, has benefited from the ability to cancel contracts for unskilled foreign workers at short notice in order to cushion the rise in domestic unemployment during economic downturns, as in 1986 and 2001, but as in Malaysia, this labor force has no permanent right of entry, unlike in the EU.

Another problem arises if the shocks facing countries are predominantly country-specific rather than regional or global, since the case for an 
Prospects for Asian monetary cooperation

Table 8.5 Regional trade, in percent of total regional GDP, 1985 and 1998

\begin{tabular}{|c|c|c|c|c|}
\hline & \multicolumn{2}{|l|}{1985} & \multicolumn{2}{|l|}{1998} \\
\hline & Exports & Imports & Exports & Imports \\
\hline \multicolumn{5}{|l|}{ ASEAN with } \\
\hline ASEAN & 5.8 & 4.9 & 11.7 & 11.8 \\
\hline Japan & 7.8 & 5.8 & 5.9 & 8.3 \\
\hline USA & 6.0 & 4.3 & 10.9 & 6.8 \\
\hline EMU & 2.6 & 2.8 & 6.3 & 4.3 \\
\hline Other industrial & 1.9 & 2.7 & 4.5 & 3.3 \\
\hline Other developing & 6.6 & 7.6 & 13.4 & 14.0 \\
\hline \multicolumn{5}{|l|}{ EMU with } \\
\hline EMU & 12.5 & 12.3 & 12.8 & 12.0 \\
\hline Japan & 0.3 & 0.8 & 0.4 & 1.0 \\
\hline USA & 2.4 & 1.9 & 2.0 & 2.0 \\
\hline Other industrial & 5.3 & 4.6 & 5.0 & 4.2 \\
\hline Other developing & 5.6 & 6.9 & 5.8 & 5.6 \\
\hline \multicolumn{5}{|l|}{ MERCOSUR with } \\
\hline MERCOSUR & 1.0 & 1.0 & 2.1 & 2.3 \\
\hline USA & 2.8 & 1.4 & 1.2 & 2.2 \\
\hline EMU & 3.0 & 1.2 & 1.7 & 2.3 \\
\hline Other industrial & 1.5 & 1.0 & 0.9 & 1.4 \\
\hline Other developing & 3.7 & 2.7 & 2.0 & 2.0 \\
\hline \multicolumn{5}{|l|}{ NAFTA with } \\
\hline NAFTA & 3.0 & 3.4 & 5.3 & 5.4 \\
\hline Japan & 0.6 & 1.7 & 0.7 & 1.5 \\
\hline EMU & 0.9 & 1.3 & 1.2 & 1.7 \\
\hline Other industrial & 0.6 & 0.8 & 0.8 & 0.8 \\
\hline Other developing & 1.7 & 2.6 & 2.5 & 4.0 \\
\hline
\end{tabular}

Source: Adapted from Bayoumi and Mauro (2001).

Notes

ASEAN comprises the ASEAN10 excluding Brunei; EMU consists of the 11 members of EMU on 1 January 1999; MERCOSUR comprises Argentina, Brazil, Paraguay, Uruguay and associate members Bolivia and Chile; NAFTA comprises Canada, Mexico and USA.

OCA is predicated on the basis of similar or highly correlated shocks among members which, by definition, would be global or regional in origin. ${ }^{15}$ Yuen (2001), for example, found some synchronization in supply shocks only for small groups of countries within East Asia such as Singapore and Malaysia, Malaysia and Indonesia, Japan and Korea, and Hong Kong and Taiwan. Chow and Kim (2000) found country-specific shocks dominated the determination of output in East Asia, in stark contrast to Europe. ${ }^{16}$ 
Table 8.6 Average intra-ASEAN5 trade flows, in percent, 1990-1996

\begin{tabular}{lrrrrr}
\hline & Indonesia & Malaysia & Philippines & Singapore & Thailand \\
\hline Origin of imports & & & & & \\
ASEAN5 & 9.3 & 18.8 & 10.3 & 20.5 & 12.9 \\
Singapore & 6.1 & 14.3 & 4.7 & - & 6.6 \\
Japan & 23.2 & 26.5 & 21.9 & 21.3 & 29.8 \\
Hong Kong & 0.9 & 2.1 & 4.9 & 3.2 & 1.3 \\
China & 3.4 & 2.3 & 1.7 & 3.1 & 2.8 \\
Korea & 6.3 & 3.3 & 4.9 & 3.5 & 3.8 \\
USA & 12.1 & 16.4 & 18.8 & 15.7 & 11.4 \\
West Europe & 22.2 & 16.2 & 11.9 & 14.6 & 17.4 \\
Others & 22.5 & 14.4 & 25.6 & 18.0 & 20.6 \\
& & & & & \\
Destination for exports & 12.6 & 28.0 & 8.6 & 24.8 & 15.6 \\
ASEAN5 & 9.0 & 21.6 & 3.9 & - & 11.4 \\
Singapore & 31.7 & 13.3 & 17.0 & 7.8 & 17.2 \\
Japan & 2.9 & 4.3 & 4.6 & 8.1 & 5.0 \\
Hong Kong & 3.7 & 2.5 & 1.2 & 2.1 & 1.8 \\
China & 6.2 & 3.4 & 2.3 & 2.6 & 1.4 \\
Korea & 13.6 & 19.6 & 37.3 & 19.6 & 20.7 \\
USA & 14.4 & 15.0 & 18.3 & 15.1 & 19.0 \\
West Europe & 15.0 & 13.9 & 10.6 & 19.9 & 19.1 \\
Others & & & & & \\
\hline
\end{tabular}

Source: Nicolas (1999).

Note

ASEAN5 comprises Indonesia, Malaysia, the Philippines, Singapore and Thailand.

\section{Political and institutional prerequisites}

Although there are differing views on the extent to which East Asia or ASEAN satisfy the economic preconditions for deeper monetary and exchange rate integration, there is much more of a consensus that Asia currently lacks the requisite institutions and socio-political forces to achieve the level of integration that has now been achieved in Europe (Nicolas 1999, Bayoumi and Mauro 2001).

To begin with, European integration has been characterized by a long period (at least 50 years) of politically-driven integration and commitment to a "European ideal", combined with the progressive delegation of a range of powers to supranational institutions. The 1957 Treaty of Rome which initiated closer economic and political coordination in Western Europe, including a customs union, was primarily motivated by the desire to contain Germany within an economic and political system which would make it impossible for its leaders to start another war with its neighbors. The first serious document on monetary integration was probably the 1971 Werner Report which envisaged monetary union within a decade. This turned out to be remarkably prophetic, albeit premature. 
The collapse of the Bretton Woods system in the early 1970s produced the "snake in the tunnel" in April 1972 when Germany, Belgium, Netherlands and Luxemburg (joined for periods by other countries) fixed their currencies within bands of 4.5 percent around central parities against the dollar and floated jointly against the outside world. The experiment was short-lived and not very successful but it was an important learning process and precursor for the EMS in 1979. The EMS included the ERM which was designed to stabilize exchange rates within plus or minus 2.25 percent of their central parities. This was more successful, especially between 1979 and 1987 (see below). The Delors Report of 1989 marked the first serious commitment to the ideal of a full monetary union, and the Maastricht Treaty of 1991 set down a detailed timetable and explicit preconditions for its achievement, including macroeconomic convergence criteria.

European integration has not always been a smooth process and there has been opposition and resistance at each stage. There were serious currency crises in 1992 and 1993 and the realization of a single market in capital and labor has been a slow process. There was public disagreement over the appointment of the first President of the European Central Bank (ECB) in 1998 and political differences surfaced in early 1999 over the correct conduct of monetary and exchange rate policy arising, in part, from ambiguities in the Maastricht Treaty. Also controversial has been the Stability and Growth Pact, under which EMU members are obliged to publish regular "stability" programs including actual and forecast fiscal deficits, with procedures for punishing if deficits exceed 3 percent of GDP. The institutions of EMU are also inadequate in the areas of transfer payments and fiscal harmonization, so there is plenty of room for political tensions.

It may not yet be a "happy family", but the EU (which includes EMU members) has achieved a substantial degree of institutional integration around a set of common values, with a significant amount of "people representation" in the European Commission, European Parliament, Court of Justice and European Central Bank, and there are in place at least some rudimentary mechanisms to compensate or redistribute from richer to poorer regions. By contrast, ASEAN is based more on the "good neighbors" principle of levelling the playing field and removing obstacles to cross-border economic activity and it is largely driven by policymakers and secretariats based on national institutions and loose networks. Little sovereignty has been surrendered and there is a distinct absence of idealists. The idea of "Asian values" turned out to be a short-lived phenomenon in the early 1990s and largely centered in Singapore, and the anti-Western rhetoric of Malaysia and Indonesia is not shared by other ASEAN members such as Singapore and the Philippines. Moreover, there is little in place by way of income transfer mechanisms. Most assistance comes from outside ASEAN, from Japan, the USA or the EU. ${ }^{17}$ 
So the options for integration in East Asia seem to be quite limited for the foreseeable future but there is still scope for cooperation in matters of trade, competition policy, labor and capital mobility and in the monetary arena through "self-help" mechanisms, such as the pooling of resources in an AMF and the establishment of monitoring and surveillance machinery.

A key litmus test will be whether East Asian countries will be willing to cooperate in exchange rate matters, which was crucial in early European experience.

\section{An Asian exchange rate mechanism? ${ }^{18}$}

The Asian financial crisis demonstrated, amongst other things, that unilateral exchange rate regimes (including de facto dollar pegging) hadn't worked very well in the 1990 s faced with massive capital inflows into the region (Kwan et al. 1998). ${ }^{19} \mathrm{~A}$ further problem was the sharp swings in the dollar-yen exchange rate. A classic case of this "third country" effect was in April 1995 when the dollar appreciated sharply against the yen, thereby reducing the competitiveness of Asian countries relative to Japan and the EU. Those countries which resisted devaluation found their nominal effective exchange rate (NEER) rising with potentially damaging effects on their current accounts.

There is also the perennial problem of competitive devaluations, since devaluations by one or a number of East Asian economies put deflationary pressures on their close competitors if they decide not to follow suit. The global slowdown in 2001 and 2002 together with yen weakness generated precisely such problems. Matters are made worse by the asymmetric needs of specific countries. Korea, for example, is more competitive in export markets with Japan, while the poorer ASEAN countries of Indonesia and the Philippines, and China are more concerned about relative currency fluctuations among themselves. This is why countries such as Japan are anxious to include discussions about the exchange rate in forums concerned with monetary cooperation, such as the Manila Framework and ASEAN +3 .

The immediate response to the Asian crisis was that if it were not possible to juggle all three economic policy objectives at once, then a "corner" solution might be better. Either keep convertibility and a stable currency but abandon monetary independence and fix the currency, preferably backed up by a currency board, or keep monetary policy and convertibility but abandon currency management and adopt a free float.

But a hard peg is perceived to be too rigid for most countries in East Asia, and with the notable exception of Hong Kong, they have not been in a hurry to give up monetary policy or their central banks. Even Malaysia, which adopted a formal peg to the dollar in September 1998, has restricted convertibility in order to maintain some control over monetary policy. On the other hand, the potential costs of a clean float are seen to 


\section{Prospects for Asian monetary cooperation}

be too great for emerging economies with weak financial infrastructure. There would be a risk of serious currency misalignment with real consequences for exports and inflation targets; and continued volatility in capital flows and foreign exchange markets, characterized by manipulation and herd behavior, runs the risk of destabilizing speculation.

A unilateral basket peg is an improvement in as much as it provides some insulation against movements in the major currencies, especially the dollar-yen rate, and reduces volatility in the NEER and REER. It is also appropriate for countries with reasonably diversified trade patterns and thus no obvious single candidate for an exchange rate anchor. Such a regime could also be a transit stage to a free float. On the other hand, it must be a credible regime backed up with good macroeconomic management if it is not to fall prey to periodic crises. The main problem, however, is that it still leaves considerable intra-East Asian instability since baskets would differ between countries and a change in the dollar-yen rate would lead to a change in intra-East Asian exchange rates with consequences for exports if the countries concerned are close competitors. In these circumstances a common exchange rate solution becomes quite appealing.

\section{A yen bloc?}

If lingering political problems could be put aside between Japan and her neighbors, a currency bloc with East Asian countries pegging to the yen as a group or increasing the weight of the yen in their unilateral currency baskets would be a neat solution (Taguchi 1998, Kwan 1998, 2000). It would insulate them from intra-East Asian fluctuations in the yen-dollar exchange rate and it could form the basis of wider monetary integration, including a common currency. Japan is already a "hegemon" of sorts given its importance in regional trade and investment and its developed country status, and there is some trade invoicing in the yen.

But a yen bloc seems rather remote at the present time. The Bank of Japan is hardly a credible anchor for monetary policy and the short-term capital market in Japan is not at present sufficiently liquid or deep to act as a regional currency center and much of Japan's exports are in fact invoiced in the dollar. There are also some well-known asymmetries in the exchange rate policy objectives of some East Asian countries. Korea, for instance, tends historically to follow a depreciating yen to retain export competitiveness in the Japanese market, while Singapore is more likely to follow an appreciating yen to subdue import prices and thus contain imported inflation. Besides, there is little evidence so far of the emergence of a de facto yen bloc (Frankel 1993, Frankel and Wei 1994, BenassyQuere 1998). 


\section{A dollar peg?}

An alternative solution would be to peg unilaterally or collectively to the dollar (or attach a large weight to it in currency baskets) in order to stabilize intra-bloc exchange rates and long-run exchange rate expectations and to anchor regional price levels and gain the benefits of a larger dollar trading zone among close trading partners (McKinnon 2000). A common currency would be better since there would be no need for an independent anchor and it would remove exchange rate uncertainty (as in EMU), but East Asia does not satisfy OCA criteria sufficiently and AMU is not imminent, so an East Asian dollar standard (EADS) would be a simple second best solution. It could be introduced more quickly than a European-style ERM, it would be better than floating, and it could build on the existing widespread use of the dollar in regional trade invoicing and reserve composition. A dollar peg would be highly transparent with immediate effects on public confidence. ${ }^{20}$

Moreover, according to Calvo and Reinhart (2000), dollar pegging is a rational response to capital market conditions in emerging economies where the domestic currency can't be used to borrow abroad so all domestic investments have a currency mismatch (borrow in foreign currency for projects which generate domestic currency) and a maturity mismatch (long-term projects financed by short-term borrowing). In the absence of hedging facilities, agents borrow in the forex market, mostly in dollars, and for the short-term so dollar pegging is then a rational response to the fear of floating.

The case for an EADS is also based on the observation that East Asia was, in fact, a dollar bloc prior to the Asian crisis and most East Asian countries have since returned to the peg. So if there has been a return to dollar pegging then all that is required is to modify the rules to make the system work better (McKinnon 2000) by, for example, limiting banks' and other financial institutions' net foreign exchange exposure and developing a long-term bond market.

The re-emergence of informal pegging to the dollar in East Asia may be a rational solution to the problems the countries face in an uncertain and competitive world, but it represents a collective choice by default based on a false sense of cohesion and leaves the region vulnerable to further competitive devaluations, currency contagion and crises. In this sense, "informal dollar pegging in a non-optimal way" strengthens the case for a collective solution, which could be a more formal dollar peg, as suggested by McKinnon and others. The case against this particular choice rests largely on the belief that East Asia with its diversified trade patterns is not a sufficient "optimal" currency area with respect to the USA in the way that many Latin American countries may be by virtue of their strong bilateral trade and investment links. So the dollar is not a natural anchor for East Asian countries. Moreover, pegging to the dollar to anchor regional price 


\section{Prospects for Asian monetary cooperation}

levels need not stabilize effective exchange rates; it provides no insulation against outside currencies (unless they also fix against the dollar) and it is not clear that East Asian countries are committed to stabilizing their price levels through exchange rate policy or in general need to adopt a nominal inflation anchor.

\section{A common basket peg?}

An alternative collective solution is to adopt a common basket peg (Williamson 1998). Using both common weights and a basket would minimize the effects of fluctuations in major currencies and at the same time minimize intra-East Asian exchange rate instability. The basket can be used to stabilize the NEER or REER with a band to adjust for misalignments, and the collective weights would obviate the problem of "beggarthy-neighbor" competitive devaluations. In essence it would be a "collective basket" instead of "collective security" as in the EADS.

Of course a common basket peg cannot simultaneously anchor the price level, and it loses some of the simplicity of the EADS. There are also technical considerations in the choice of common weights and political compromises, since the weights are unlikely to match exactly the optimal weights in a country's own basket so the common NEER or REER may be too strong or too weak for some countries.

Hence again the importance of evidence of sufficient OCA integration, but this is less demanding than when a single anchor is used as in the EADS. Williamson himself uses direction of trade and export similarity indices to support the case that his sample is of competing countries. Eichengreen and Bayoumi (1998) also constructed a common basket using Williamson-type weights and concluded that there was no obvious common anchor and a common basket worked nearly as well as choosing any one of the anchors for most countries. But it did not work so well for Hong Kong and Singapore, which would clearly prefer to peg to the dollar, while Indonesia, Korea, and Thailand marginally prefer the yen, and Malaysia, Philippines and Taiwan marginally prefer the dollar.

\section{An Asian ERM?}

As with the common basket peg, the main objective of an ERM solution would be to stabilize intra-bloc exchange rates, but this would be achieved through some principle of joint intervention and there would be access to pooled short-term credit facilities. It could be based around an adjustable peg with central parities and a reasonably wide band to allow for periodic adjustment of exchange rates as fundamentals change without generating speculative crises. Limited capital controls could be used, at least in the early stages, to buy time to make the necessary adjustments before a fullblown crisis materialized. 
In this sense East Asia would be following in the footsteps of Western Europe when the breakdown of the Bretton Woods system of fixed exchange rates in the early 1970 s led to generalized floating and the choice was then between returning to a dollar peg or pegging to a regional anchor. In the European case, the social costs of floating exchange rates together with the perceived costs of intra-bloc instability, particularly the threat it posed to other areas of economic integration (which had been proceeding well since 1960), produced first the "snake in the tunnel" in the early 1970s, the EMS in 1979, and a de facto anchor to the Deutsche mark in the 1980s to capture the benefits of the low German inflation rate. Note that in the early stages of exchange rate cooperation, the desire to anchor price levels was probably not the key driving force.

By most accounts (De Grauwe 1997) the EMS worked quite well in its early years between 1979 and 1987, with small but frequent realignments; margins were flexible enough compared to the rigidity of the Bretton Woods system to allow adjustment to fundamentals such as differential inflation rates, without incurring major crises. The capital controls which were still present at this time probably also reduced the potential funds available for speculation and bought time for realignments. It was only when the EMS evolved into a more rigid system between 1987 and 1993 that it was unable to cope, with no realignments until the currency crisis of 1992.

In spite of deficiencies, European experience in exchange rate cooperation may be more relevant to East Asia than that of other monetary blocs. Given the direction of East Asian trade there is no natural external anchor for the system, unlike the rand bloc based on South Africa, or the CFA franc-zone in Africa based on the French franc, and dollarization or a formal dollar peg is less attractive (except by default) than in say, Latin America. However, unlike the EMS, there is no obvious candidate for a regional anchor in the absence of a yen bloc, so a common fix to the currencies of close trading partners and a joint float against the rest of the world would be more realistic.

There are also political advantages from the flexibility of an ERM-type of mechanism since members would initially retain a significant amount of independence in fiscal policy and other areas of economic "sovereignty", and as in the European case, there would need to be room for experimentation and periodic crises. If governments in East Asia are concerned primarily with intra-bloc instability (as opposed to anchoring price levels) and the need to find a more permanent solution to the monetary and exchange rate problems thrown up by the Asian crisis, then institutionalized negotiations to devise an Asian equivalent to the ERM, with a fair degree of built-in flexibility, is a politically feasible option. From the point of view of domestic politics, politicians would be showing commitment without sacrificing too much, and inter-country negotiations could leave plenty of room for compromise. It is also an attractive option for 


\section{Prospects for Asian monetary cooperation}

bureaucrats and economists; not least because there is a ready-made "model" and Europe would probably be keen to "export" some of its experience (via ASEM) in return for some increase in political leverage.

\section{A common monetary policy but not yet?}

A common currency peg in East Asia seems unlikely in the immediate future. Although there is now a significant amount of intra-bloc trade and investment, the economic and political preconditions for a common monetary policy are not sufficiently present, and it is not at all clear empirically that the benefits would outweigh the costs. It is also made more difficult by the greater openness of international capital markets today compared to the situation facing Europe in the past. Policymakers in the region do, however, appear to be concerned about the effects of exchange rate changes and intra-bloc currency instability on their competitive positions and this should provide some scope for a continuing dialogue about exchange rate issues which might lead to a common exchange rate mechanism in the future. Even a return to de facto dollar pegging would be better addressed by more transparency and coordination than at present.

\section{Conclusion}

An East Asian monetary union is not on the horizon, not least because of the difficulty in identifying a coherent group of countries in East Asia satisfying some minimum criteria for an OCA with sufficient similarity as far as asymmetric shocks are concerned and, at the same time, with a sufficiently strong political commitment to develop the requisite institutional structure and pool of sovereignty to have any chance of success. But this does not preclude further steps towards closer regional monetary and exchange rate cooperation, particularly if there is a repeat of the Asian financial crisis of 1997-1998.

Before the crisis there existed only a rudimentary infrastructure of monetary cooperation. The Asian crisis may have widened economic disparities in the region but it also renewed political and academic interest in the prospects for closer monetary and exchange rate cooperation. The result was a flurry of initiatives, including the formalization of a regional network of repurchase agreements and currency swap arrangements, the development of regional mechanisms for crisis surveillance and monitoring, and the beginnings of discussions about the possibility of a common exchange rate system. Machinery for information sharing and macroeconomic surveillance to anticipate future crises is not hard to set up, requires little by way of commitment or sacrifice of sovereignty and is a prerequisite for further integration such as an AMF and common exchange rate system. Monetary cooperation is at last on the move in East Asia. 
Although the 1997 Japanese proposal for an AMF was rejected, under pressure from the IMF and Washington, a good case can be made for placing responsibility for the functions of macroeconomic surveillance and regional resource pooling within a permanent institution which could evolve over time into a fully-fledged Fund with its own Asia-specific rules on conditionality. The resources available under the Chiang Mai Initiative are clearly inadequate and there would be significant economies of scale from more extensive resource pooling. Support for an AMF is increasing, not least as a reaction to the problems thrown up by the Asian crisis itself: the difficulties of implementing unilateral exchange rate policy in a world of increasing trade interdependence and capital mobility; the inadequacy of existing global institutions in dealing with regional crises; and the need for regional, if not international, institutions to internalize the spillover effects arising from globalization. If political problems can be overcome, an AMF would be a crucial, affordable, and relatively painless, first step towards developing distinctly East Asian institutions and beginning the long path towards monetary and exchange rate integration.

A common exchange rate policy is less likely in the foreseeable future until the net economic benefits of giving up unilateral exchange rate regimes are more apparent and there is sufficient political commitment to Asian monetary integration, but a key indicator of East Asian commitment to monetary cooperation will be whether they are willing to discuss a common exchange rate system. In the early stages the prerequisites for this are not as demanding as for a monetary union. All it requires is a belief that unilateral exchange rate regimes can be improved upon through a collective system aimed at reducing intra-bloc exchange rate instability and the threat of competitive devaluations, or the anchoring of price levels, for countries which are close competitors. The construction of a currency unit based on a common basket peg would be a possible first step and this reference unit could be linked to access to funds from a common resource pool. A yen bloc would be a nice solution since it would also solve the problem of a regional anchor, but there is little evidence historically for the natural development of such a bloc, and it is doubtful that Japan can provide the necessary economic and political leadership for it to work, at least until it has solved its own problems. As a collective solution an EADS is also quite appealing, since there is evidence for it de facto, so all that needs to be done is to formalize it and make it work better. But pegging to the dollar will not necessarily stabilize intra-bloc exchange rates and it is not clear that the USA is a suitable candidate for a common anchor for all East Asian countries except by default. A common basket peg will do this but requires common weights in the basket, which need not suit all members. An ERM solution, which is not inconsistent with some kind of common basket principle, loses the simplicity of the yen bloc, EADS and common basket peg, but might be more appealing politically if the arrangements are flexible enough to leave countries initially 
with sufficient independence in macroeconomic policy, and it can build on European experience.

\section{Notes}

1 I would like to thank the Staff of the Regional Economic Monitoring Unit at the Asian Development Bank, particularly Jay Menon, for helpful comments on an earlier draft.

2 The GDP figures are from Tongzon (1998: 16) and the trade share was calculated from the International Monetary Fund, Direction of Trade Statistics, 1997.

3 ASEAN6 comprises Indonesia, Malaysia, the Philippines, Singapore, Thailand and Brunei.

4 ASEAN10 comprises all the current member countries of Brunei, Cambodia, Indonesia, Laos, Malaysia, Myanmar, the Philippines, Singapore, Thailand and Vietnam.

5 For further details on changes in Singapore's global perspectives, see Peebles and Wilson (2002).

6 As Stanley Fischer put it, an Asian Monetary Fund would be "a threat to the authority and effectiveness of the IMF”, as quoted in Chan and Rajan (2001).

7 Both REMU and ARIC can be found at http://www.aric.adb.org.

8 For further details on the Kobe Research Project, see www.rieb.kobe-u.ac.jp or www.worldbank.org.

9 For a recent review of such sentiments, see Rana (2002).

10 For a quantitative estimate of how regional and global contagion effects can spread through trade links to countries in East Asia, see Abeysinghe (2001).

11 In fact, Singapore already has a curious currency union with Brunei through a "currency interchangeability arrangement". See Peebles and Wilson (2002: 240).

12 Such indicators might comprise inflation, unemployment, budget deficits (indicating fiscal sustainability so there is less need for monetary policy), interest rates and exchange rates.

13 MERCOSUR is comprised of Argentina, Brazil, Paraguay, Uruguay and associate members Bolivia and Chile. Members of NAFTA (North American Free Trade Agreement) are Canada, Mexico and the USA.

14 For ASEAN6, about 21.7 percent of their total trade is intra-bloc in 1999, falling to 18.6 if Singapore is excluded (IMF Direction of Trade Statistics, October 2000).

15 Country-specific shocks might be changes in monetary or fiscal policy, in productivity, or in the terms of trade, while regional shocks from the East Asian point of view could arise from changes in the yen-dollar rate or China's accession to the World Trade Organization. Global shocks might include an oil price hike or the terrorist attacks in the USA in September 2001.

16 Interesting for those of us who think that EMU should have proceeded on the basis of the more integrated "core" countries first, non-core countries in Europe (such as Spain and Portugal) were also subject to a higher proportion of country-specific shocks.

17 This contrast between the European "happy family" model of integration and the "good neighbors" model, was recently expressed by Pascal Lamy, the EU Trade Representative (Business Times 18 February 2002).

18 The literature on the choice of an exchange rate regime is voluminous. In the Asian context, see the readings in Collignon et al. (1998).

19 Although as Nicolas (1999) has pointed out, the dollar peg was good for the Asian "miracle" between 1985 and 1995, when it increased trade and investment and encouraged the relocation of production from Japan, as yen appreciation made it cheaper to produce abroad in the "dollar zone". 
20 Robert Mundell has also proposed that Hong Kong fully dollarize in order to speed up monetary convergence in East Asia. Since China is already effectively pegged to the dollar, an explicit ASEAN +3 peg to the dollar would encourage convergence to an Asian dollar area as an interim step towards a common currency.

\section{References}

Abeysinghe, T. (2001) "Thai meltdown and transmission of recession within ASEAN4 and NIE4", in S. Claessens (ed.) International Financial Contagion, Boston: Kluwer Academic Publishers.

Bayoumi, T. (1994) "A formal model of optimum currency areas", International Monetary Fund Staff Papers, 41: 537-554.

Bayoumi, T. and Eichengreen, B. (1994) "One money or many? Analyzing the prospects for monetary unification in various parts of the world", Princeton Studies in International Finance, 76.

Bayoumi, T. and Mauro, P. (2001) "The suitability of ASEAN for a regional currency arrangement", The World Economy, 24(7): 933-954.

Benassy-Quere, A. (1998) "Exchange rate regimes and policies", in S. Collignon, J. Pisani-Ferry and Y.C. Park (eds) Exchange Rate Policies in Emerging Asian Countries, London: Routledge.

Business Times (18 February 2002), Singapore.

Calvo, G. and Reinhart, C. (2000) Fear of Floating, University of Maryland.

Chan, L.L. and Rajan, R. (2001) "The economics and politics of monetary regionalism", ASEANEconomic Bulletin, 18(1).

Chow, H.K. and Kim, Y. (2000) "Exchange rate policy in Singapore: prospects for a common currency peg in East Asia", The Singapore Economic Review, 45(3): 139-164.

Collignon, S., Pisani-Ferry, J. and Park, Y.C. (eds) (1998) Exchange Rate Policies in Emerging Asian Countries, London: Routledge.

De Grauwe, P. (1997) The Economics of Monetary Integration, Oxford: Oxford University Press.

Eichengreen, B. and Bayoumi, T. (1998) "Is Asia an optimum currency area? Can it become one? Regional, global and historical perspectives on Asian monetary relations", in S. Collignon, J. Pisani-Ferry and Y.C. Park (eds) Exchange Rate Policies in Emerging Asian Countries, London: Routledge.

Frankel, J. (1993) "Is Japan creating a yen bloc in East Asia and the Pacific?", working paper WP C93-007, Center for International and Development Economics Research, University of California, Berkeley.

Frankel, J. and Rose, A. (1998) "The endogeneity of the optimum currency criteria", Economic Journal, 108: 1009-1025.

Frankel, J and Wei, S.J. (1994) "Yen bloc or dollar bloc? Exchange rate policies of the East Asian economies", in T. Ito and A.O. Krueger (eds) Macroeconomic Linkages, Chicago: University of Chicago Press.

Goto, J. and Hamada, K. (1994) "Economic preconditions for Asian regional integration", in T. Ito and A.O. Krueger (eds) Macroeconomic Linkages, Chicago: University of Chicago Press.

IMF (various years) Direction of Trade Statistics, Washington, D.C.: International Monetary Fund. 
(various years) International Financial Statistics, Washington, D.C.: International Monetary Fund.

Kenen, P.B. (1969) "Theory of optimum currency areas", in R. Mundell and A. Swoboda (eds) Monetary Problems in the International Economy, Chicago: University of Chicago Press.

Kwan, C.H. (1998) "The possibility of forming a yen bloc in Asia", Journal of Asian Economics, 9(4): 555-580.

- (2000) "The possibility of forming a yen bloc revisited", ASEAN Economic Bulletin, 17(2): 218-232.

Kwan, C.H., Vanderbrink, D. and Yue, C.S. (eds) (1998) Coping with Capital Flows in East Asia, Singapore: Nomura Research Institute (Tokyo) and Institute of Southeast Asian Studies.

McKinnon, R. (1963) "Optimal currency areas", American Economic Review, 53: $1-25$.

— (2000) "After the crisis, the East Asian dollar standard resurrected: an interpretation of high frequency exchange rate pegging", paper presented to the 25th Federation of ASEAN Economic Associations Conference, 7-8 September, Singapore.

Ministry of Information and the Arts (2002) Singapore 2002, Singapore: Ministry of Information and the Arts.

Mundell, R. (1961) "A theory of optimum currency areas", American Economic Review, 51: 657-665.

(1973) Uncommon arguments for common currencies", in H.G. Johnson and A.K. Swoboda (eds) The Economics of Common Currencies, London: Allen and Unwin.

Nicolas, F. (1999) "Is there a case for a single currency within ASEAN?" The Singapore Economic Review, 44(1): 1-25.

Park, D.Y. (2000) "Intra-Southeast Asian income convergence", ASEAN Economic Bulletin, 17(3): 285-292.

Peebles, G. and Wilson, P. (2002) Economic Growth and Development in Singapore: Past and Future, Cheltenham: Edward Elgar.

Pomfret, R. (1996) "ASEAN - always at the crossroads?" Journal of the Asia Pacific Economy, 1(3): 365-390.

Rana, P.B. (2002) "Monetary and financial cooperation in East Asia: The Chiang Mai initiative and beyond", ERD Working Paper 6, Manila: Asian Development Bank. Online. Available at: <http://aric.adb.org/> (accessed 4 December 2002).

Rose, A. (1999) Is There a Case for an Asian Monetary Fund? FRBSF Economic Letter 99-37.

- (2000) "One money, one market: estimating the effect of common currencies on trade”, Economic Policy, 15(30): 7-46.

Taguchi, H. (1998) "On the internationalization of the Japanese yen", in T. Ito and A.O. Krueger (eds) Macroeconomic Linkages, Chicago: University of Chicago Press.

Tavlas, G. (1994) "The theory of monetary integration", Open Economies Review, 5: 211-230.

Tongzon, J. (1998) The Economics of Southeast Asia: The Growth and Development of ASEAN Economies, Cheltenham: Edward Elgar.

Williamson, J. (1998) "The case for a common basket peg for East Asian curren- 
cies”, in S. Collignon, J. Pisani-Ferry, and Y.C. Park (eds) Exchange Rate Policies in Emerging Asian Countries, London: Routledge.

Wilson, P. (1998) European Monetary Union: Will it Succeed or Fail? NUS Economic Policy Forum, EPF 98/5, Singapore: National University of Singapore.

Wong, J. (1988) "The Association of Southeast Asian Nations", in A.M. El-Agraa (ed.) International Economic Integration, London: Macmillan.

World Bank (various years) World Development Report, Washington, D.C.: The World Bank and Oxford University Press.

Yuen, H. (2000) "A cluster-based approach for identifying East Asian economies: a foundation for monetary integration", National University of Singapore Staff Working Paper.

- (2001) "Optimum currency areas in East Asia: a structural VAR approach", ASEAN Economic Bulletin, 18(2): 206-217.

Yeung, M.T., Perdikis, N. and Kerr, W.A. (1999) Regional Trading Blocks in the Global Economy: the EU and ASEAN, Northhampton, MA: Edward Elgar. 


\section{Index}

Some locator numbers have a one-letter suffix: $\mathrm{f}$ refers to a figure; $\mathrm{n}$ refers to a note; $t$ refers to a table.

AFTA (ASEAN Free Trade Area) 150-1, 172; backdoor entry 158 , 161-3; commodity coverage 152; economic initiative 155; foreign trade policy 156 ; tariffs $152,166 \mathrm{n}$ agriculture 32; changes in 136; farmers' debt suspension program 142; reduction of hours/wages 99 allocation of resources 2, 113; efficiency $12,132,182$

anchoring price levels 193

ASEAN 28-9, 67, 168-9, 186t; benefit from extra-ASEAN FTAs 158; commodities 155; disparity of membership 155, 158, 169; economy $7,150-1,155$; human resource development 159; policies 171 ASEAN+3 7, 173, 178, 181, 197n ASEAN4 152, 166n

ASEAN5 29, 185; trade flows $187 \mathrm{t}$ ASEAN6 151-2, 154-5, 166n, 196n ASEAN8+3 foreign exchange reserves 179

ASEAN10 165n, 169, 196n

ASEAN Free Trade Area see AFTA Asian currency arrangements 173-4, $174 \mathrm{t}$; cooperation in 176-7, 195 Asian ERM solution 192-3

Asian exchange rate volatility $174-6,175 \mathrm{t}$ Asian financial crisis 1997-1998 22-3, 173-5; causes 49, 127-8, 179-80; diagnosis 176 ; impact on vulnerable groups $98,144,151$

Asian Monetary Fund (AMF) 7, 168, $180-1,189$; rejected $177,179,195$, $196 n$
Asian Monetary Union 168, 183-4, 194

Bank for International Settlements see BIS

Bank of Japan 190

basket peg 174, 190, 192

bilateral FTAs with non-ASEAN countries $150,157,161-2,171$

bioinformatics 69n; Asia-Pacific Bioinformatics Network 64 BIS ratio 16,23

business specialization 49

Cambodia 2, 4, 32-6

capital controls 15-17, 19 cashcrop production for export 128 Central Bank of Indonesia 73, 83

CEPT 151-2, 162-3, 166n; product list $153 \mathrm{t}$; tariff rates $152 \mathrm{t}$

Chiang Mai Initiative 7, 177, 179, 195

China as a competitor 4, 20, 65; car industry 66-7; labor intensive goods 46n; liberalized economy 28; producer/exporter 41, 46n; technological advances 65-6 China as a market 66-7; major economic power 130; membership of WTO 151, 181; trade policies 66

Common Effective Preferential Tariffs see CEPT

common exchange rate system 171 , $184,190,194-5$

competition for inward FDI 38-9 competitive devaluation $189,191-2,195$ competitiveness of Asian countries 59, 68,189 
corner solution 176,189

corporate debt restructuring 139 cost of institutional change 131, 151 creativity and entrepreneurship 38-40 crisis management policies $176,180-1$ cross-border flows 16-17, 51, 184;

labor 185; production systems 67 currency $168,176-8,182-3$; attacks 17 ,

177; bloc 190; common anchor 192; common basket 191-2, 195; common fix 193; crises 173, 180; crisis (Europe) 188; mismatch 190-1; pegging 174-6 184, 189, 191-4, 197n; stabilization 81 current account 29, 29t, 151

decentralization 52, 118, 141-2

Department of Science and Technology see DOST

depreciation 3, 74, 182

deregulation 3,165

devaluation 175; of rupiah and baht 128

disparity in development and technology 51, 173

domestic capital-intensive industries 161 domestic financial issues $182-4$ DOST 53-5

e-ASEAN initiative 158,166 n

East Asian Dollar Standard 191, 195 economic development within ASEAN 30, 49-50, 60; disparities 41, 168, 175,194

economic growth $68,127-9,131$ economic indicators $169,170 \mathrm{t}$

economic integration $154-5,157,169$, 184

economies of scale $133,179,182$

education 6, 29-30; compulsory 34; demand, change in 102-3; dropout rates 43; enrollment see education enrollment; focus, change in 39 ; improvements in 36, 44-5; key element in economic development 44; mean years of schooling 32-3, $33 \mathrm{t}$; as predictor of poverty 94 ; primary 30, 36; reforms 5, 29, 39 45 ; secondary 30 ; standards 30,32 , $36,38,45$

education enrollment $30,32,35$; affected by birth rate 106; all levels $105,105 f$, 106; primary $33,43,37$; ratios $33,34 t, 92-3,107$; secondary
$34,37,109,38,43$; tertiary $34,41-2$, $105-6$

education expenditure $30,31 \mathrm{t}, 43$; Indonesia 38, 43; Malaysia 37, 45, 61-2; Singapore 94, 103-5, 103t, 104f, 106; Thailand 37, 106-7, 107t, $109,118,121 \mathrm{n}, 141$

education in Indonesia 37-8; compulsory 37,43 ; curriculum 44 ; decentralization 44; economic difficulties for schools 43 ; private schools and institutes 38,43 ; scholarships, fees and costs 37,43 ; standards and quality $37-8,44,57$; unemployment, university graduates 38

education in Malaysia 42; bumiputera students 41-3, 45; Chinese students 41; curriculum 37; emphasis on religious studies 42; political difficulties 45 ; quota system $42,46 \mathrm{n}$; religious school students 42 ; returns on investment 37 ; technical education 37 ; tertiary students 61 ; university admissions quota 41,45

education in the Philippines: science and engineering graduates 53 education in Singapore 91; bonded government scholarships $40-1$; budget cuts 118; engineering 34 ; subsidized 106; overseas universities 105; policy 103; pressure on children to study 39 ; teaching children at home 33-4; university entrance criteria 39

education in Thailand 91-2; access to higher education 37, 141; assistance programs 117 ; compulsory 37,106 ; disparity 92,100 ; dropout rates 107-9; 108f, 141; free 92; increased demand 107; literacy rate 106 ; loan fund $117-18,120 \mathrm{n}$; quality and standards 36-7; science and technology 37; student loans 141; vocational schools 107

education at tertiary level 30 ; archaic system 37 ; students by field of study $35 \mathrm{t}$; graduates low standard 42 ; science and engineering 37, 46n; unemployment 41-2;

EMU 183, 196n

European experience, building on 196; exchange rate cooperation 193; regional cooperation 187 
European Free Trade Association (EFTA) countries 157

European integration 187-8

exchange rate and monetary regimes 29t $151,173,182,190-3,196 n$; Indonesia 79-80, 80t, 82; Singapore 105; Thailand 136; unilateral 168 , $175,189,195$

exploitation of natural resources 141, 156

export: competitiveness 174-6

industries 55 ; niches 49,54 ; policies

67; production expansion 136

external borrowing patterns 72

external sources of technology 58

Foreign Direct Investment (FDI) 50, 56, 63; inflow 19, 20,67; link with human capital development 58,68 ; reliance on 41 ; restrictive policies towards 56

financial contagion 168, 176, 180, 191, $196 n$

financial and corporate reforms 180

fiscal policies 3; deficits, forecasts of 188; externalities 182

floats 79, 81, 193

foreign exchange: earnings 56 ; exposure 191; markets 85,177 ; reserves 4,179

foreign investors $16-19,57,160$

foreign workers: in Hong Kong, Malaysia and Singapore 185; and inequality 101; in research and development 50; in Singapore, Thailand 101; to upgrade production 36

Free Trade Area (FTA) 157, 172; with extra-ASEAN countries, implications 156; trade flows 161

GDP growth 169, 171, 196n; in Indonesia $74-5,75 \mathrm{t}, 76 \mathrm{t}$; in Thailand 92,135

General Exclusion List 152

global economy 4, 50-1, 68; ASEAN's share 169; recession 16

globalization of markets 180

Granger-causality test $82-5$

government expenditure 94, 95t, 106; grants for industrial innovation 49-50

health sector: Singapore $91,94,112$,
118; Thailand 91, 112, 118, 141;

insurance $55,110,112,115,143$

high-tariff economies 165; automotive imports $163,166 \mathrm{n}$

hollow middle strategy 81

household income and budget: allocation to education 106,118 Indonesia 75-6, 121n; medical expenditure 110; Singapore 96, 97t; Thailand 109

human resource development 36,51 , $53,60,136 \mathrm{t}, 150$

IBRA litigation cases 74

IMF 4, 15-18, 23, 168, 177; borrowing 178; policies of retrenchment $26 \mathrm{n}$; program for assistance $24,73,138$, 178

incentives $11,30,40,57,63-4$

Inclusion Lists 152, 153t, 154; sensitive products 152

income per capita 36t, 171; ASEAN 169; lack of convergence 185

income and educational level 100-2, $101 \mathrm{f}$

income inequality and poverty 6,91 , 96, 102, 112-13; in Singapore 96-7, 113-14, 118; in Thailand 92, 100-2

Indonesia 4-6, 29, 32-3, 36, 40; banking see Indonesia's banking sector; corporate distress 88 ; democratization 4; deposit rate 85-6, 86t; development finance 77; economy 1, 43-4; government blanket guarantee 77-8; government programs 44, 46n; industry contraction $75-6$; labor market 58 ; new industrial sectors 55; oil revenues 37 ; political decentralization 43-4; poverty 43 ; regional income difference 46n; science and technology policy 57

Indonesia's banking sector: bankruptcies 86 ; base money 79 , 81-2, 84-5; credits 72, 73t, 78; debts $76-7,86$; depreciation of assets 74 ; FDI 55-8; interest rate $88 \mathrm{n}$; monetary authorities 84 ; monetary policies $73,81,83,85$; performance 86 ; positive gross profits 86,87 ; recovery 88 ; SBI rates 83

Indonesian Banking Restructuring Agency (IBRA) 73

industrialization $54,56-8,60,63$ 
inequality indices 169

inflation $85,91,102,118,135,171$,

$174,182-3,193$

infocommunications and e-commerce industries 158

information technology 49 ; infrastructure $61,63,64,67$

innovation 50,68; domestic 40, 50

Institute of Technical Education, Singapore 105-6

institutional arrangements 130 ; influence of the poor in 134

institutional change 9-16, 24, 25n, 129

181 ; congruent with pro-poor growth

134; framework 11, 129, 131; sources of 131

institutional and structural issues 129-33

institutions and organizations, interdependency between 131

institutions for macro-/micro-economic development 132

integration of East Asian economies 176,189

intellectual property rights $69 \mathrm{n}$

international capital markets 176, 194

International Monetary Fund see IMF

intra-ASEAN trade 185; competition for non-ASEAN markets 151

intra-bloc currency, trade and investment 190-4

investment climate $75-6,76,128,160$

investor confidence $16,18,20$

Japan 4, 7; bilateral deals 177; capital market 190; economy 13; trade and investment 190

Japan-Singapore Free Trade Agreement (JSFTA) 156, 158, 166n; effect on ASEAN 159

Japanese investment in ASEAN countries 158-60, 163; automotive firms 163; production 161, 163; tourism 159

job loss 151; East Asia 118; Singapore 119; Thailand 98-9, 102, 128-9, 135-6; see also underemployment, unemployment

Keynesian reflationary policies $16-17$ knowledge-based economy (KBE) 51;

Singapore 62-3; Vietnam 58-9

Kobe Research Project 7, 178

Korea 9, 12, 15-18, 40; asset sales
18-19; corporate sector 22, 22t, 23; economy 20; FDI inflows 18t, 19; GDP 16, 22; institutional transitions $15,17,22-3$

labor force $36,59-61,65,92,135,141$; low-cost 49, 68; migrant workers 120 ; mobility $64,101,182$; nonagricultural 31-2; rapid growth of 38 ; skilled 97, 105; unskilled 94, 185

labor-intensive production $41,67,135$

labor market 58, 100, 102; flexible 185 see also job loss, underemployment, unemployment

Laos 2, 4, 30, 32-6

liberalization 2, 4, 16-17; economic power spillover effects 165 ; economies 28; Thailand 98; trade 4, 150-1, 154, 156, 165, 176; trade within FTAs 157, 160-1, 165; Vietnam 59

liquidation: banks 79; companies 23

liquidity constraints 19 ; crunch 17,73 ; short-term 177; support 79

literacy rates $30,33,33 t, 35$; adult 32 ; illiteracy 92

low-income health card 114-115

Maastricht Treaty 1991 185, 188

macroeconomic indicators $74-5,82$, 145-6, 184

Malaysia: Action Plan for Industrial Technology 60; asset sales 17-18, 24; automotive industry 154,157 , 162, 165n, 172; bumiputera policies 41-2; corporate sector 22-4; economic zones 62; FDI inflows $18 \mathrm{t}$, 19-20, 61-2; GDP per capita 60-1; labor force 61; Multimedia Super Corridor (MSC) 61-2; new industrial cities 61 ; restructuring policy 16

Manila Framework Group 177, 189

markets 50-1, 132

money and exchange rate cooperation 168, 176-8, 181, 184, 189; Europe 188

money and exchange rate integration $169,171,181-2,187,190,195$; costs and benefits 183; Europe 187

monitoring and surveillance 181,189 multinational companies 52, 68 ; globalization 51-2

Myanmar 4, 30, 32-4, 36 


\section{Index}

National Center for Natural Science and Technology 59

national income 90, 102

negative-interest spreads $83 f, 86,88$, $89 n$

New-Zealand-Singapore FTA 156 , $166 n$

nominal effective exchange rate (NEER) 175,189

nominal exchange rate $89 n$; changes 176

non-performing loans (NPLs) 16 , 20-3; classification scheme 21t; gross 87f; in Indonesia 73; in Korea and Malaysia 20-1, 21t, 22; ratio to total loans 20

non-tariff barriers, elimination/ harmonization of 154

optimum currency area (OCA) 181; benefits and costs 182

Parti Islam SeMalaysia (PAS) 42 path-dependence 11-14; forces influencing 14

pegging: to the dollar 191-2, 195, $197 \mathrm{n}$; to a regional anchor 193 ; to the yen 190

pharmaceutical-manufacturing center in Singapore 64-5

Philippine Institute of Development Studies (PIDS) 53

Philippine Research Education and Government Information Network 55

Philippines 4, 6, 29-30, 33-6, 40, 68; DOST 53-5; education-friendly policies 30; science and technology policies 54; skilled worker shortage 37

political reform 144

political turmoil in Indonesia and the Philippines 49, 67, 160

pooling of reserves $177,179,184,189$, 192

poor people: behavioral constraints 129,134 ; below the poverty line 128 , 137-8; educational effects of poor nutrition $121 \mathrm{n}$; free school lunch program 117; importance of markets 146; incentives 129; livelihoods 133-4, 137; means-tested program 114-15; migration 100, 134-6; no voice in negotiation 134; numbers reduced 127; reliance on informal networks 134; vulnerability 129 , 134; withdrawal into self-sufficiency 134 post-crisis institutional adjustment 144-5

poverty alleviation $1,4,6,9,128-9$, 135 ; poverty line $113,119,120 \mathrm{n}$ prerequisites for integration, political and institutional 187

private sector $41,54,58$; enterprise 172

pro-poor growth $129,133,135,145-6$; index 146n; institutional approach 133

product diversification 183

property rights $1,10-11,132-3$

racial riots in Malaysia 41 real effective exchange rate (REER) 176

real income/wages $86,99,99 f, 102$, $120 \mathrm{n}, 135$

recapitalization $78 \mathrm{t}, 138-9$

redistribution of gains from growth $133-4,188$

regional differences: 62,92

regional initiatives $165,176,178,180$

regional trade bloc 181

regionalism: enlarging markets 165 ; trend towards 156-7, 160

rice, self-sufficiency in 154

risk-taking 39-40; in the economy 16 , $25 n$; function 17,23 ; mechanism 10 , 16

rules of origin $161,166 \mathrm{n}$

rupiah 82-3, 85; Granger-causality 83, $84 \mathrm{t}$; nominal exchange rate 80 ; volatility $80-1,81 \mathrm{f}, 85$

schools, availability and number 32; curriculum 32

Science and Technology Agenda for National Development (STAND) 54

science and technology policies 50-1; Philippines 53; Singapore 64;

Vietnam 58-60

second-best theorem $11,25 n$

sensitive products, integration into CEPT 152-4

shocks $5,6,182-3,194,196 n$; country specific 185-6; felt most by the poor 120n; global or regional 186 ; industry-specific 183; supply shocks 184-6 
Singapore 2, 4-7, 29-30, 32-6, 38; aging population 38 ; biomedical initiatives 64; Central Provident Fund 94-5, 111-13, 121n; Chilean and US initiatives 158; competing globally 65; currency union with Brunei 196n; decrease in wages 118 ; foreign labor 63, 97; Gini coefficient 96; global perspectives $196 \mathrm{n}$; industrial activities 63,172 ; innovation 63,65 ; labor force 36 , 65,92 ; life sciences industry 65 ; policy $34-5$; R\&D structure 63 ; retirement balance 112; skill redevelopment program 106; skilled population 63

Singapore and ASEAN 156; direct investment in ASEAN countries 164, 166n; AFTA agreement 155; softloans to countries in need 164

Singapore and extra-ASEAN FTAs 150 156-8, 160-2, 164-5; backdoor entry to AFTA 162; bilateral pact with Japan 157; motivations 157, 164, 166n

Skill Development Center (Singapore) 106

social safety nets 113,119

South Korea see Korea

Soviet Union, collapse of 130

spillover effects 180; across national boundaries 176; from globalization 195; from Singapore-Japan trade pact 160

state-owned enterprises 59-60, 63, 77, 151

state involvement $13,53,58$

surveillance and regulation of markets $3,5,177$

targeting welfare assistance 113 , 117-19, 129

tariff-free access to ASEAN markets 161-2 tariff rates: differential 162

harmonization 165 ; for nonmembers 161; reductions in 151 , 154-5, 162, 172; UAP tariff lines 152

teachers 30-2; as government employees 44 ; ratios with students 31-2, 45; salaries 37,43

technological development 50-2, 56, $60,62,67-9$; innovation 29,38

technology policies $50,52-3$

Temporary Exclusion List (TEL) 152, 172
Thai Rak Thai Party 142, 144-5

Thailand 4, 6, 29-30, 32-6; aggregate demand 142; average income 94, 137; budget deficits 142; business earnings decreased 98-9; capital investment budget 110; changes in agricultural production 136; child labor 109; closures 118; constitutional reform 144-5; corruption 140, 145; credit dried up 136; current account deficit 98 ; development policies 138; economic growth 135, 138; economic institutions and reforms 139-40, 144; financial restructuring package 139; Gini coefficient 100, 100f; government spending $95 \mathrm{t}, 116 \mathrm{t}$; health services 111, 120n, 143; household income 100t; income inequality 91 ; industrial/export interests 141 ; institutional arrangements 140; institutional changes 144-5; labor force 135-41; labor market 100, 102; medical care provision 96, 110-11, 115, 118-19; own businesses 99; poverty 92-4, 101-2; pluri-activity in rural households 136; social sector programs 140, 145; social security cards $115-17$

Third Outline Perspective Plan 60 trade barriers, elimination 155 trade deflection $166 \mathrm{n}, 172$ trans-Pacific cooperation 177 transaction costs 5; analysis 24; changes in 12; economics $9,10-13$ transfer of technology: 54, 56-7, 59, 63 transition costs $5,9,14-15,17,24$

underemployment 99, 137

unemployment 4, 6, 25n, 26, 91, 128, 137; of children in Thailand 109; and poverty 150-1; in Singapore 96, 97f, 98f; in Thailand 107; of whitecollar workers 34

US-Singapore agreement 158

US-Vietnam bilateral trade accord 151

Vietnam 2, 4, 6, 30, 32-3, 35-6, 68; development strategy 151; economic growth 92; fiscal crisis 59; Foreign Investment Law 59; foreign partners 59 ; government funding 59 ; industrialization and economic 


\section{Index}

Vietnam continued growth 58,60; information technology 58; institutions for research and technology 58; labor force 59-60; private enterprise law 58; research and industry 59; science and technology policies 58-60

volatility index 79 ; models of 80,81 , 88n; NEER and REER 190

voluntary health card 110,115

vulnerable groups $114,119,135,140$

welfare assistance 11 ; external 188 ;

Singapore 94; Thailand 142, 145 women in work 92,106 ; lack of parttime opportunities 121n

World Trade Organization (WTO)

151; trade negotiations 156

yen bloc $173,190,195$

yen-dollar exchange rate $189-90$

yen in swap agreements 178

zero transaction cost model 11 

